\title{
Physical, Chemical, and Isotopic Data from Groundwater in the Watershed of Mirror Lake, and in the Vicinity of Hubbard Brook, near West Thornton, New Hampshire, 1983 to 1997
}

By James W. LaBaugh, Philip T. Harte, Allen M. Shapiro, Paul A. Hsieh, Carole D. Johnson, Daniel J. Goode, Warren W. Wood, Donald C. Buso, Gene E. Likens, and Thomas C. Winter

Open-File Report 2013-1087 


\title{
U.S. Department of the Interior SALLY JEWELL, Secretary
}

\section{U.S. Geological Survey Suzette M. Kimball, Acting Director}

\author{
U.S. Geological Survey, Reston, Virginia: 2013
}

For more information on the USGS - the Federal source for science about the Earth, its natural and living resources, natural hazards, and the environment, visit http://www.usgs.gov or call 1-888-ASK-USGS.

For an overview of USGS information products, including maps, imagery, and publications, visit http://www.usgs.gov/pubprod

To order this and other USGS information products, visit http://store.usgs.gov

Any use of trade, firm, or product names is for descriptive purposes only and does not imply endorsement by the U.S. Government.

Although this information product, for the most part, is in the public domain, it also may contain copyrighted materials as noted in the text. Permission to reproduce copyrighted items must be secured from the copyright owner.

Suggested citation:

LaBaugh, J.W., Harte, P.T., Shapiro, A.M., Hsieh, P.A., Johnson, C.D., Goode, D. J., Wood, W.W., Buso, D.C., Likens, G.E., and Winter, T.C., 2013, Physical, chemical, and isotopic data from groundwater in the watershed of Mirror Lake, and in the vicinity of Hubbard Brook, near West Thornton, New Hampshire, 1983 to 1997: U.S. Geological Survey Open-File Report 2013-1087, 147 p., http://dx.doi.org/10.3133/ofr20131087. (Available only online.) 


\section{Acknowledgments}

Partial funding for this study was from a National Science Foundation grant to G.E. Likens, Institute of Ecosystem Studies. The U.S. Geological Survey Toxic Substances Hydrology Program provided partial funding for the the study of groundwater in fractured bedrock beginning in 1989 . 



\section{Contents}

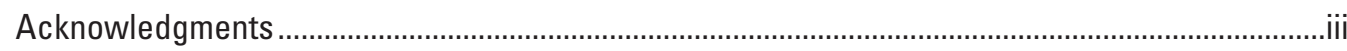

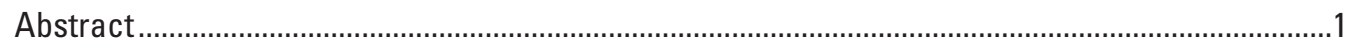

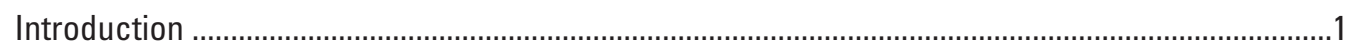

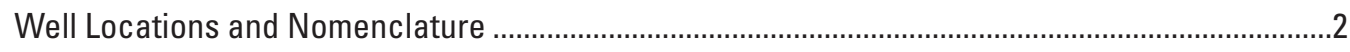

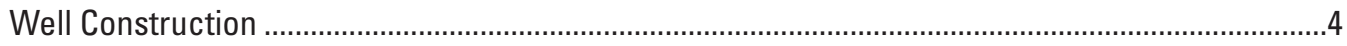

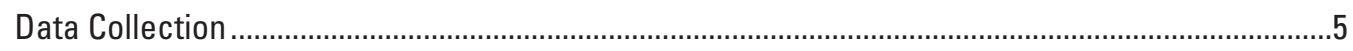

Collection of Water for Physical, Chemical, and Isotopic Analyses .......................................

Water Collection Procedures Used in 1983, 1984, 1986, 1987, and $1988 \ldots \ldots \ldots \ldots \ldots \ldots \ldots \ldots \ldots . . . .5$

Water Collection Procedures Used in 1990, 1991, 1992, 1993, 1995, 1996, and $1997 \ldots \ldots . . .7$

Methods of Physical, Chemical, and Isotopic Analysis ........................................................10

Methods of Analysis Used in 1983, 1984, 1986, 1987, and 1988 ......................................10

Methods of Analysis Used in 1990, 1991, 1992, 1993, 1995, 1996, and 1997 ....................10

Measurement of Physical and Chemical Characteristics Within Wells in 1987 and 1988......11

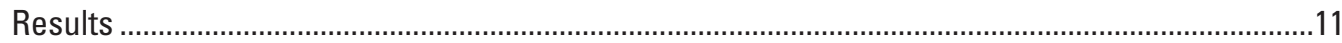

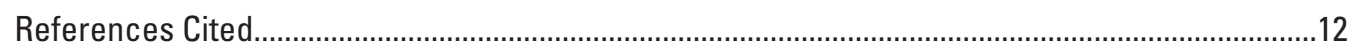

Tables

\section{Figures}

1. Location of a seep, water-table wells, piezometers, and well nests containing multiple piezometers in close proximity as of 1997, for which data are presented in

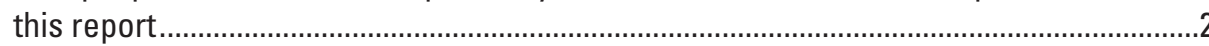

2. Location of a spring, bedrock wells, and well fields containing multiple bedrock wells in close proximity as of 1997, for which data are presented in this report...............3

\section{Tables}

1. Summary of water-table wells, piezometers, bedrock wells, a seep, a spring, and a domestic bedrock well in the Mirror Lake watershed, New Hampshire, from which water was collected for analysis, or physical and chemical measurements were made within the wells from 1983 to 1997.

2. Summary of water-table wells, piezometers, and bedrock wells in the Mirror Lake watershed, New Hampshire, including those from which water was collected for chemical analysis or measured within the well from 1983 to 1988.

3. Wells and zones sampled during phase one of a groundwater study in the Mirror Lake watershed, New Hampshire, May 9 to June 4, 1990.

4. Wells and zones sampled during phase two of a groundwater study in the Mirror Lake watershed, New Hampshire, June 21 to September 23, 1990

5. Wells sampled during phase three of a groundwater study in the Mirror Lake watershed, New Hampshire, November through December, 1990

6. Water evacuation data for wells in the Mirror Lake watershed, New Hampshire, from which water was collected for physical, chemical, and isotopic analyses in $1990 \ldots \ldots . . .26$ 
7. Chemical constituents and their collection and preservation procedures for water samples collected in the Mirror Lake watershed, New Hampshire, in $1990 \ldots \ldots \ldots \ldots \ldots \ldots . . .29$

8. Wells and zones sampled in the Mirror Lake watershed, New Hampshire, in 1991 .......30

9. Wells and zones pumped or sampled (or both) in the Mirror Lake watershed, New Hampshire, in 1992 and 1993

10. Wells and zones sampled in the Mirror Lake watershed, New Hampshire, in 1995 .......34

11. Wells sampled in the Mirror Lake watershed, New Hampshire, in 1996 ........................36

12. Wells and zones, a seep, and a spring sampled in the Mirror Lake watershed, New Hampshire, in 1997

13. Procedures and equipment used for sample collection from water-table wells and piezometers in the Mirror Lake watershed, New Hampshire, in 1995, 1996, and 1997 ...38

14. Analytical methods and reporting procedures for samples collected in the Mirror Lake watershed, New Hampshire, in 1990

15. In situ temperature, $\mathrm{pH}$, and specific conductance of groundwater within the casing or borehole of selected wells measured in the Mirror Lake watershed, New Hampshire, July 1987

16. Vertical variation of in situ temperature, $\mathrm{pH}$, and specific conductance of groundwater in the Mirror Lake watershed, New Hampshire, within bedrock wells FS1 (sampled July 10, 1987) and FSE1 (sampled July 7, 1987).

17. In situ temperature, $\mathrm{pH}$, and specific conductance of groundwater measured in selected wells in the Mirror Lake watershed, New Hampshire, July 19, 1988.

18. Vertical variation of in situ temperature, $\mathrm{pH}$, and specific conductance of groundwater in the Mirror Lake watershed, New Hampshire, in bedrock well FS1 and adjacent piezometers FS1-25 and FS1-35, July 20, 1988.

19. Vertical variation of in situ temperature, $\mathrm{pH}$, and specific conductance of groundwater in the Mirror Lake watershed, New Hampshire, in bedrock well FS2 and adjacent piezometer FS2-25, July 20, 1988

20. Vertical variation of in situ temperature, $\mathrm{pH}$, and specific conductance of groundwater in the Mirror Lake watershed, New Hampshire, in bedrock well FSE2 and adjacent piezometers FSE-23, FSE-32, and FSE-43, July 20, 1988.

21. Vertical variation of in situ temperature, $\mathrm{pH}$, and specific conductance of groundwater in the Mirror Lake watershed, New Hampshire, in bedrock well FSE3, July 20, 1988 .

22. Vertical variation of in situ temperature, $\mathrm{pH}$, and specific conductance of groundwater in the Mirror Lake watershed, New Hampshire, in bedrock well FSE4, July 20, 1988

23. Vertical variation of in situ temperature, $\mathrm{pH}$, and specific conductance of groundwater in the Mirror Lake watershed, New Hampshire, in bedrock well TR1 and adjacent water-table well TR1-63 and piezometer TR1-132, July 19, 1988.

24. Vertical variation of in situ temperature, $\mathrm{pH}$, and specific conductance of groundwater in the Mirror Lake watershed, New Hampshire, in bedrock well K2 and adjacent piezometers K2-21, K2-31, and K2-41, July 19, 1988.

25. Vertical variation of in situ temperature, $\mathrm{pH}$, and specific conductance of groundwater in the Mirror Lake watershed, New Hampshire, in bedrock well CO1 and adjacent water-table well CO WT, July 19, 1988

26. Summary of physical and chemical field parameters from groundwater samples collected in the vicinity of Mirror Lake, New Hampshire, in 1990.

27. Physical and chemical characteristics of water collected from selected wells, a seep and a spring in the vicinity of Mirror Lake, New Hampshire, 1993, 1995, 1996, and 1997. 
28. Radon survey of water collected from selected wells in the vicinity of Mirror Lake, New Hampshire, 1992 and 1993.

29. Chemical characteristics of water collected from selected wells, a seep, and a spring in the Mirror Lake watershed, New Hampshire, for $\mathrm{pH}$, specific conductance, calcium, magnesium, sodium, potassium, chloride, sulfate, and alkalinity

30. Chemical characteristics of groundwater from selected wells, a seep, and a spring in the Mirror Lake watershed, New Hampshire, for nitrite, nitrite plus nitrate, nitrate, ammonium, total Kjeldahl, ortho-phosphorus, and total phosphorus

31. Chemical characteristics of water collected from selected wells, a seep, and a spring in the Mirror Lake Watershed, New Hampshire, for aluminium, silica (as $\mathrm{SiO2),} \mathrm{bromide,} \mathrm{fluoride,} \mathrm{iodide,} \mathrm{iron,} \mathrm{and} \mathrm{manganese.}$

32. Chemical characteristics of water collected from selected wells, a seep, and a spring in the Mirror Lake watershed, New Hampshire, for barium, beryllium, boron, cadmium, chromium, cobalt, copper, and lead.

33. Chemical characteristics of water collected from selected wells, a seep, and a spring in the Mirror Lake watershed, New Hampshire, for lithium, molybdenum, nickel, silver, strontium, vanadium, zinc, and silicon...

34. Radiochemical isotopic characteristics of groundwater collected from selected wells, a seep, and a spring in the Mirror Lake watershed, New Hampshire, for radon, radium 226, radium 228 , uranium U-234/U-235/U-238 (speciation method), uranium-234 (alpha method), uranium-235 (alpha method), uranium-238 (apha method), uranium in milligrams per lliter, and tritium .

35. Isotopic characteristics of groundwater collected from selected wells, a seep, and a spring in the Mirror Lake watershed, New Hampshire, for stable isotope ratios ......117

36. Isotopic characteristics of water collected over time from a single well (CO1) in the vicinity of Mirror Lake, New Hampshire, 1996, for stable isotope ratios.

37. Isotopic characteristics of water collected over time from a single well (CO1) in the vicinity of Mirror Lake, New Hampshire, 1996, for tritium.

38. Concentrations of gases and excess air and nitrogen in groundwater collected from selected wells in the Mirror Lake watershed, New Hampshire.

39. Concentrations of gases dissolved in water collected from selected wells in the Mirror Lake watershed, New Hampshire: chlorofluorocarbons

40. Chemical characteristics of groundwater from bedrock well FSE4 in the Mirror Lake watershed, New Hampshire.

41. Chemical characteristics of water collected from selected wells in the Mirror Lake watershed, New Hampshire: hardness .

42. Physical, chemical, radiochemical isotope, and stable isotope ratio characteristics of water collected from Mirror Lake, New Hampshire, August 1,1993.

43. Helium data for water collected from selected wells in the Mirror Lake watershed, New Hampshire 


\section{Conversion Factors}

Inch/Pound to SI

\begin{tabular}{|c|c|c|}
\hline Multiply & By & To obtain \\
\hline inch & 2.54 & centimeter \\
\hline foot & 0.3048 & meter (m) \\
\hline
\end{tabular}

SI to Inch/Pound

\begin{tabular}{|c|c|c|}
\hline Multiply & By & To obtain \\
\hline \multicolumn{3}{|c|}{ Length } \\
\hline centimeter $(\mathrm{cm})$ & 0.3937 & inch (in.) \\
\hline millimeter $(\mathrm{mm})$ & 0.03937 & inch (in.) \\
\hline meter $(\mathrm{m})$ & 3.281 & foot (ft) \\
\hline \multicolumn{3}{|c|}{ Area } \\
\hline square meter (m2) & 0.0002471 & acre \\
\hline \multicolumn{3}{|c|}{ Volume } \\
\hline liter (L) & 0.2642 & gallon (gal) \\
\hline milliliter $(\mathrm{mL})$ & 0.0338 & ounce, U.S. fluid (oz) \\
\hline \multicolumn{3}{|c|}{ Flow rate } \\
\hline liter per minute $(\mathrm{L} / \mathrm{min})$. & 0.2642 & gallon per minute (gal/min) \\
\hline \multicolumn{3}{|c|}{ Mass } \\
\hline $\operatorname{gram}(\mathrm{g})$ & 0.03527 & ounce, avoirdupois (oz) \\
\hline milligram (mg) & $3.527 \times 10^{-5}$ & ounce, advoirdupois (oz) \\
\hline kilogram (kg) & 2.205 & pound avoirdupois (lb) \\
\hline
\end{tabular}

Temperature in degrees Celsius $\left({ }^{\circ} \mathrm{C}\right)$ may be converted to degrees Fahrenheit $\left({ }^{\circ} \mathrm{F}\right)$ as follows:

${ }^{\circ} \mathrm{F}=\left(1.8 \mathrm{x}^{\circ} \mathrm{C}\right)+32$

Vertical coordinate information is referenced to the North American Vertical Datum of 1988 (NAVD 88).

Horizontal coordinate information is referenced to the North American Datum of 1983 (NAD 83).

Altitude, as used in this report, refers to distance above the vertical datum.

Specific conductance is given in microsiemens per centimeter at 25 degrees Celsius $(\mu \mathrm{S} / \mathrm{cm}$ at $\left.25^{\circ} \mathrm{C}\right)$.

Concentrations of chemical constituents in water are given either in milligrams per liter (mg/L) or micrograms per liter ( $\mu \mathrm{g} / \mathrm{L}$ ), except for Alkalinity or Acid Neutralizing Capacity (ANC) which also is given in microequivalents per liter (eq/L). 


\title{
Physical, Chemical, and Isotopic Data from Groundwater in the Watershed of Mirror Lake, and in the Vicinity of Hubbard Brook, near West Thornton, New Hampshire, 1983 to 1997
}

\author{
By James W. LaBaugh, ${ }^{1}$ Philip T. Harte, ${ }^{1}$ Allen M. Shapiro, ${ }^{1}$ Paul A. Hsieh, ${ }^{1}$ Carole D. Johnson, ${ }^{1}$ \\ Daniel J. Goode, ${ }^{1}$ Warren W. Wood, ${ }^{1}$ Donald C. Buso ${ }^{2}$, Gene E. Likens, ${ }^{2}$ and Thomas C. Winter ${ }^{1}$
}

\section{Abstract}

Research on the hydrogeologic setting of Mirror Lake near West Thornton, New Hampshire (43 $56.5^{\prime}$ $\left.\mathrm{N}, 71^{\circ} 41.5^{\prime} \mathrm{W}\right)$, includes the study of the physical, chemical, and isotopic characteristics of groundwater in the vicinity of the lake and nearby Hubbard Brook. Presented here are those physical, chemical, and isotopic data for the period 1983 to 1997. Data were collected from observation wells installed in glacial drift and bedrock, as well as from one domestic well in the general area of the lake and Hubbard Brook. Also presented are data for Mirror Lake for August 1, 1993, to place groundwater data in context with chemical and isotopic characteristics of the lake.

\section{Introduction}

Physical, chemical, and isotopic data were collected from groundwater in the vicinity of Mirror Lake, and nearby Hubbard Brook near West Thornton, New Hampshire, as part of a study of the hydrogeologic characteristics of the groundwater flow systems in the vicinity of the lake. The study was conducted by the U.S. Geological Survey (USGS) and the Institute of Ecosystem Studies (IES). Mirror Lake and its watershed are being studied, in part, to relate the interaction of the lake with groundwater to hydrologcal, biogeochemical, and ecological characteristics of the lake (Winter, 1984; Likens, 1985; Johnson and Dunstan, 1998; Winter and Likens, 2009). The groundwater flow system in the watershed of Mirror Lake includes flow in glacial drift and fractured bedrock (Winter, 1984; Tiedeman and others, 1997). Detailed investigation of groundwater flow in fractured bedrock was conducted at the study site to improve understanding of groundwater flow in fractured rock in general, as well as groundwater flow in relation to Mirror Lake in particular (Shapiro and others, 1995). Mirror Lake was chosen for detailed research that characterizes groundwater flow in fractured rock so that techniques and methods developed at this pristine site could then be used in the USGS Toxic Substances Hydrology Program to investigate groundwater flow in fractured rocks at contaminated sites. The purpose of this report is to present physical, chemical, and isotopic data collected from groundwater in the observation wells installed in kame terraces, glacial till, and bedrock at the site. Data presented herein were obtained from 1983 to 1997. Readers, thereby, are provided access to the entire set of data that served as the basis for various interpretive studies about the

\footnotetext{
${ }^{1}$ U.S. Geological Survey.

${ }^{2}$ Cary Institute of Ecosystem Studies (known as the Institute of Ecosystem Studies during the period of study presented herein).
} 
lake and its groundwater flow system (Harte and Winter, 1996; Morganwalp and Aronson, 1996; Harte, 1997; Tiedeman and others, 1997; Goode, 1998; Goode and others, 1999; Morganwalp and Buxton, 1999; Rosenberry and others, 1999; Shapiro, 2001; Wood and others, 2004; Shapiro and others, 2007; Winter and others, 2008; Winter and Likens, 2009; Likens and Buso, 2010).

\section{Well Locations and Nomenclature}

The location of wells installed at the site for the purpose of studying the groundwater flow system of Mirror Lake and its watershed and the groundwater flow in the vicinity of Hubbard Brook - and for which data are presented in this report — are shown in figures 1 and 2. Table 1 provides a list of those wells. In some cases, the designation for individual wells changed during the period of study. Table 1 includes the previous designations for those wells to enable readers to correlate information presented in this report with information about these wells contained in earlier publications.

The term "piezometer" generally is associated with wells in which well screens lie either in the range of fluctuations in the water table or are below the range of fluctuations in the water table. For the purpose of this report, however, wells in glacial material in which well screens lie within the range of fluctuations

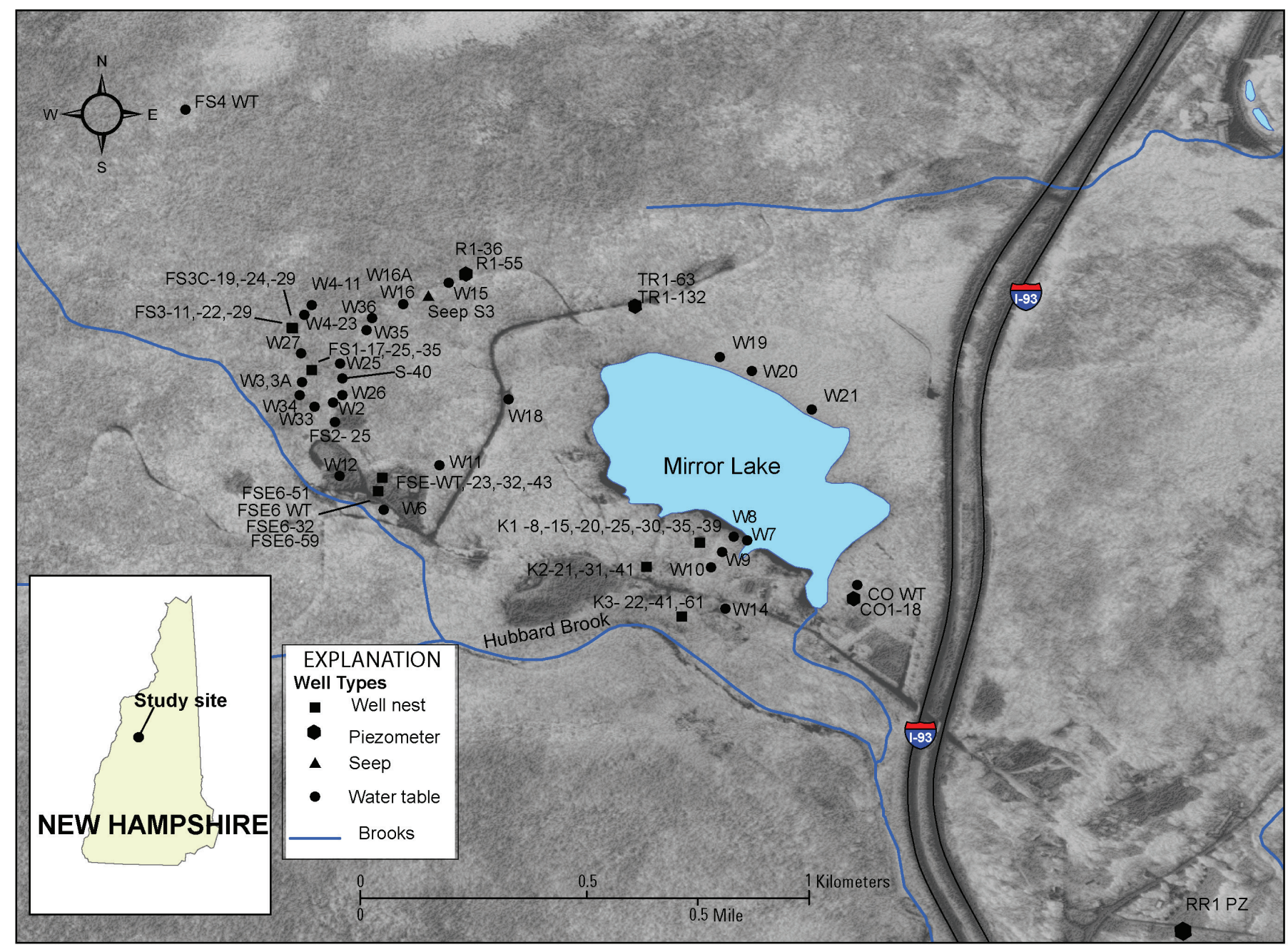

Figure 1. Location of a seep, water-table wells, piezometers, and well nests containing multiple piezometers in close proximity as of 1997, for which data are presented in this report, modified from Tiedeman and others (1997), Goode and others (1999), and Morganwalp and Buxton (1999). 


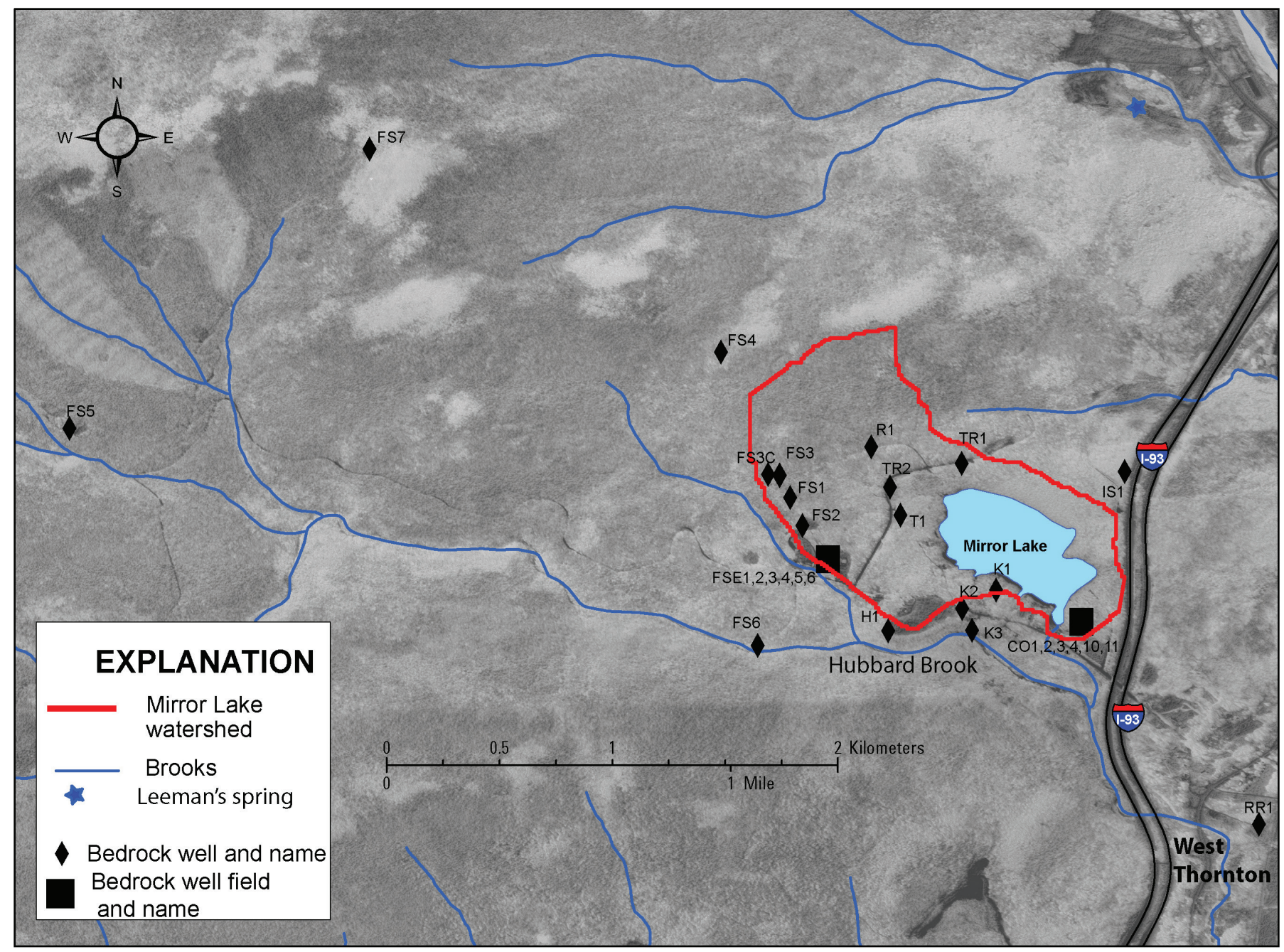

Figure 2. Location of a spring, bedrock wells, and well fields containing multiple bedrock wells in close proximity as of 1997, for which data are presented in this report, modified from Tiedeman and others (1997), Goode and others (1999), and Morganwalp and Buxton (1999).

in the water table are termed "water-table wells". Wells in glacial material in which well screens are below the range of fluctuations in the water table are termed "piezometers". The piezometers include wells that were identified as potentiometers in previous publications about groundwater studies in the vicinity of Mirror Lake, such as Winter (1984).

Groups of bedrock wells were placed in selected locations (fig. 2), commonly in association with a water-table well or a water-table well and piezometers. These groupings, or well fields, included the Camp Osceola (CO) well field and the Hubbard Brook Forest Service Experimental (FSE) Forest well field. Other bedrock wells were associated with various areas of the watershed and in the vicinity of Hubbard Brook, including the Forest Service (FS) area, the Hamlet (H) area, the Interstate (IS) area, the Kendall-Kettaneh (K) area, the Richards (R) area, the Thomas (T) area, the Town Road (TR) area, and the Railroad (RR) area which lies just outside of the watershed of the lake in the vicinity of West Thornton between Hubbard Brook and the Pemigewasset River. The Pemigewasset River is east of the interstate highway shown in figures 1 and 2. The Shattuck (S) area was examined by Patricia Shattuck, University of New Hampshire, to determine the relation of the water-table gradient to the west tributary of the Mirror Lake watershed (Shattuck, 1991). The abbreviations of the well fields and areas noted in parentheses above are used in the well names at the study site. 
In this report, water-table wells are identified by the letter W followed by a number, such as W2, or letter designations associated with various well fields as follows: CO WT, FS1-17, FS2-25, FS3-11, FS4 WT, FSE WT, FSE6 WT, K1-8, K2-21, K3-22, R1-36, RR1 PZ, S-40, and TR1-63. Wells designated with a $\mathrm{W}$ prefix were those water-table wells not located in close association with a cluster of other wells. Water-table wells designated with a W prefix include a number in that designation that refers to the order in which wells were installed. Water-table wells located in close proximity to a bedrock well are identified by a prefix that is the designation for the bedrock well, followed by either the abbreviation "WT", "PZ", or a number that is the depth of the water-table well in feet below land surface. For example, water-table well FS1-17 is the water-table well located in the vicinity of bedrock well FS1 and has a total depth of 17 feet below land surface.

Piezometers are identified as CO1-18, FS1-25, FS1-35, FS3-22, FS3-29, FS3C-19, FS3C-24, FS3C29, FSE-23, FSE-32, FSE-43, FSE6-32, FSE6-51, FSE6-59, K1-15, K1-20, K1-25, K1-30, K1-35, K1-39, K2-31, K2-41, K3-41, K3-61, R1-55, and TR1-132. The piezometers are all located in close proximity to a specific bedrock well. Piezometers are identified by a prefix that is the designation of the bedrock well in proximity with the piezometer, followed by a number that is the depth of the piezometer in feet below land surface. For example, piezometer CO1-18 is the piezometer located in the vicinity of bedrock well CO1 and has a total depth of 18 feet below land surface.

Bedrock wells are identified as CO1, CO2, CO3, CO4, CO10, CO11, FS1, FS2, FS3, FS5, FS6, FS7, FS3C, FSE1, FSE2, FSE3, FSE4, FSE5, FSE6, H1, IS1, K1, K2, K3, R1, RR1, T1, TR1, and TR2. The domestic supply well, which is identified as Pleasant View well, lies to the east of Mirror Lake.

\section{Well Construction}

Descriptions of these wells (other than the domestic supply well), including details of well construction, are presented in Winter (1984), Shattuck (1991), Harte (1997), Goode (1998), Johnson and Dunstan (1998), and Winter and Likens (2009). Details of well construction are briefly described herein. The wells included water-table wells and piezometers drilled into glacial material overlying bedrock, as well as wells drilled into bedrock. Water-table wells were constructed by placing casing and well screen into holes drilled by hollow-stem auger, without using water or drilling mud during drilling, or rotary drilling without mud for one specific well (FSE6 WT). No Portland cement was used in the construction of water-table wells. In some water-table wells the sides of the augered holes collapsed around the well screen and casing during withdrawal of the auger, and any remaining space between the casing and drilled hole was filled with the drill cuttings - the material removed during drilling (CO WT, FS1-17, FS2-25, FS3-11, FSE6 WT, K2-21, K1-8, K2-21, K3-22, R1-36, S-40,TR1-63, W6, W7, W8, W9, W10, W11, W12, W13, W14, W15, W16, W18, W25, W26, and W27). In wells W16A, W33, W34, W35, W36, and FS4 WT, coarse sand was placed in the annulus around the well screen, followed by natural backfill (drill cuttings), followed by a layer of ground silica flour, followed by natural backfill to the surface. The purpose of the fine-grained ground silica was to minimize vertical flow within the annulus of the drilled hole. In other water-table wells, the space between the well screen and drilled hole was filled with number 10 to number 30 silica sand, with either drill cuttings used as fill above the screen (W2, W3A, W4-23) or "bentonite" (sodium montmorillonite clay - Driscoll, 1986) and drill cuttings (W3, W4-11).

Piezometers were constructed by placing casing and well screen into holes drilled by the mud-rotary method. In piezometers CO1-18, FS1-25, FS1-35, FS3-22, FS3-29, FSE-23, FSE-32, FSE-43, K1-15, K1-20, K1-25, K1-30, K1-35, K1-39, K2-31, K2-41, K3-41, K3-61, and TR1-132, petal-cement baskets were fixed above the top of the well screen prior to emplacement. After placement, cement (Portland cement and water) was pumped into the annular space between the casing and walls of the hole above the petal-cement basket. In piezometers FS3C-19, FS3C-24, FS3C-29, FSE6-32, FSE6-51, FSE6-59, and 
R1-55, sand, or glass beads in the case of FS3C piezometers, were used to fill the annulus around the well screen. The height of the sand or glass beads above the well screen was checked before placing 1 to 2 feet of Bentonite pellets above the sand or glass beads. The pellets were allowed to swell to separate the sand (or glass beads) from the grouted portion of the well prior to pumping cement into the annular space between the casing and walls of the hole above the sand or glass packed around the well screen. Thus, the well screen in all of the piezometers commonly was greater than 10 feet below the water table.

Bedrock wells were open holes drilled into the bedrock that were cased through the overlying glacial drift with casing set into the upper 10 feet of the bedrock. Cement filled the annular space between the outside of the casing and the bedrock wall and drift wall. Below the casing, the bedrock wells were an open hole for the remainder of their depth. Characteristics of fractured bedrock within selected wells are provided by Paillet and Kapucu (1989), Johnson and Dunstan (1998), and in selected articles in Morganwalp and Aronson (1996) and Morganwalp and Buxton (1999).

\section{Data Collection}

\section{Collection of Water for Physical, Chemical, and Isotopic Analyses}

\section{Water Collection Procedures Used in 1983, 1984, 1986, 1987, and 1988}

In 1983 and 1984, selected water-table wells, piezometers, and a bedrock well were sampled (see table 2) to determine the spatial variability in chemical characteristics of groundwater in the Mirror Lake watershed. Water-table wells were sampled to provide information on horizontal variability; at the same time, piezometers were sampled to define vertical variability in the groundwater flow system. The bedrock well was sampled so that the chemical characteristics of groundwater in the bedrock could be compared to the chemical characteristics of groundwater in the glacial drift.

Samples were collected from water-table wells, piezometers, and a bedrock well by use of bailers, a pitcher pump, a peristaltic pump, and a Middleburg pump (bladder pump) during the period July 27 to August 5, 1983. In general, a peristaltic pump was used in wells that had water levels within 30 feet of the top of the well casing. For selected wells, independent of well depth, water was removed from the well using a bailer. In other selected wells in which the water level was too deep to use the peristaltic pump (deeper than 30 feet), water was removed from the well using a bailer until there was sufficient water to prime the pitcher pump. The pitcher pump was then installed, primed, and a specific volume of water was removed (approximately three times the volume of water in the well casing prior to priming) prior to collection of a sample for subsequent chemical analysis. In selected wells, a Middleburg bladder pump was used. The Middleburg pump, constructed of stainless steel and Teflon, was lowered into the well and then sufficient water was removed to assure groundwater being collected was representative of water in the geological material in the vicinity of the well screen.

In 1983 some samples were not filtered prior to analysis. To determine the effect filtering had on analysis, groundwater from selected wells was collected twice, once to provide an unfiltered sample and a second time to provide a filtered sample. All filtered samples were filtered through a 0.4- micrometer (mm) pore-size Nucleopore filter.

During the period June 26 to July 3, 1984, samples were collected from selected water-table wells and piezometers (see table 2) by use of either a peristaltic pump or bailer. Approximately three times the volume of water in the well casing was removed prior to sample collection. A peristaltic pump was used in wells that had water levels within 30 feet of the top of the well casing. A bailer was used in those wells in which levels were deeper than 30 feet below the top of the well casing.

All samples collected in 1984 were filtered through a 0.45 -mm pore-size, 142-millimeter (mm) diameter Gelman GA-6 membrane filter (Gelman number 60117, lot 4059054). Water was pumped directly 
from the well using a peristaltic pump (portable Masterflex sampling pump) using Nalgene 8000 nontoxic autoclavable laboratory/food grade tubing (1/4-inch interior diameter, 1/8-inch wall) with Masterflex silicone tubing in the pump head. Water pumped from the well was pumped through an acrylic backflush filter assembly containing the membrane filter, and the filtrate was collected for subsequent chemical analysis.

During the period October 22 to October 30, 1986, samples were collected from individual fractures in bedrock well FSE4 and from piezometers FSE-23 and FSE-32. A peristaltic pump was used to collect samples from the piezometers; unfiltered water was pumped directly from the well into sample bottles, while filtered water was obtained by filtration through an acrylic backflush filter assembly containing a 0.45-mm pore-size, 142-mm diameter Gelman membrane filter, type GA-6 (lot number 7). Water was collected from individual fractures by first inflating neoprene rubber bladders (known as packers) to expand to the rock wall of the borehole above and below the fracture to isolate the fracture. Once the fracture was isolated, a Bennett pump (piston pump) placed within the isolated zone was used to lift water to land surface. At land surface, unfiltered water was directed into sample bottles for subsequent analyses of unfiltered water. Also at land surface, unfiltered water was pumped through a filter assembly using a peristaltic pump, and the resulting filtrate was directed into sample bottles for subsequent analyses of filtered water. The peristaltic pump and filter assembly was the same as was used for the collection of water from the piezometers. Descriptions of the types of pumps used (peristaltic, bladder, piston) to collect groundwater samples for chemical analysis are found in Lane and others (2003).

During the period July 7 to July 10, 1987, samples were collected from water-table wells using a peristaltic pump and filter assembly in the same manner as was done for the piezometers sampled in 1986. On July 21, 1988, water was collected from well CO WT in the same way as for wells sampled in 1987. Processing of samples in the field in 1987 and 1988 was the same as in 1986 . The same analyses were done on samples collected in 1987 and 1988 as were done for the samples collected in 1986.

Samples collected for analysis by the USGS National Water Quality Laboratory in Denver, Colorado, were packed in ice, placed in an insulated shipping container, and sent to the laboratory for chemical analysis. Prior to shipment to the laboratory for analysis, water was collected as follows. Unfiltered water was collected in a 500-milliliter (mL) high-density polyethylene (HDPE) bottle for subsequent analysis of $\mathrm{pH}$, specific conductance, and total alkalinity. Unfiltered water collected in an amber 250-mL HDPE bottle was preserved with $1 \mathrm{~mL}$ of mercuric chloride $(\mathrm{HgCl})$ for subsequent analysis of total phosphorus, total kjeldahl nitrogen, total ammonium, and total nitrate plus nitrite. Filtrate was collected in two additional 500-mL HDPE bottles, one acid rinsed with nitric acid $\left(\mathrm{HNO}_{3}\right)$ and the other not acid rinsed, and one amber 250-mL bottle. These bottles were rinsed three times with filtrate prior to sample collection. One milliliter of $\mathrm{HNO}_{3}$ was added to the acid-rinsed bottle, the contents of which were analyzed for dissolved aluminum, calcium, iron, lithium, magnesium, manganese, molybdenum, potassium, and sodium. The contents of the other 500-mL bottle was analyzed for dissolved bromide, chloride, fluoride, iodide, silica (as $\mathrm{SiO}_{2}$ ), and sulfate. One milliliter of $\mathrm{HgCl}$ preservative was added to the contents of the amber bottle receiving filtrate for subsequent analysis of dissolved ammonium, nitrate plus nitrite, and orthophosphorus.

An additional 250-mL glass bottle was filled with unfiltered water prior to shipment to the National Water Quality Laboratory for analysis. The contents of this bottle were used to determine the stable isotope composition for oxygen and hydrogen as the ratio between heavier and lighter isotopes of the sample relative to the ratio in a standard (abbreviated as $\delta^{18} \mathrm{O}$ for oxygen and $\delta^{2} \mathrm{H}$ for hydrogen). An explanation of this nomenclature for stable isotopes is provided in Kendall and others (1995).

Samples collected for analysis by the Institute of Ecosystem Studies (IES) laboratory in Millbrook, New York, were processed in the field as follows. Unfiltered water was put into a $250-\mathrm{mL}$ bottle and fixed with appropriate reagents for subsequent dissolved oxygen analyses at the site by Donald C. Buso (IES). Filtered water was collected in one $250-\mathrm{mL}$ bottle for analysis of dissolved chemical constituents. These bottles were refrigerated after sample collection for subsequent shipment to the IES laboratory 
for chemical analysis according to methods described in Buso and others (2000). The concentration of dissolved inorganic carbon (DIC), dissolved organic carbon (DOC), and methane $\left(\mathrm{CH}_{4}\right)$ for each sample was determined at the Pleasant View Farm Laboratory (currently known as the Henrietta Kendall Towers Lab of the Hubbard Brook Research Foundation) near West Thornton, New Hampshire, by Scott Nolan and Donald C. Buso after collection in a biological oxygen demand (BOD) bottle, which was refrigerated for 2 days before the contents were analysed.

\section{Water Collection Procedures Used in 1990, 1991, 1992, 1993, 1995, 1996, and 1997}

In general, collection procedures for 1990 to 1997 followed existing guidelines (Wood, 1976; Lane and others, 2003). The National Water Quality Laboratory implements quality control on analytical methods.

Geochemical samples were collected in three phases during calendar year 1990. For the first phase, samples were collected from May 9 to June 4 at 10 bedrock wells and 16 glacial drift wells (table 3 ). In the second phase, 14 samples were collected from June 21 to September 23 from discrete fractures at 6 bedrock wells (table 4). In the third phase, groundwater was collected at $15 \mathrm{drift}$ wells in November through December, 1990 (table 5).

Phase one samples are from large bedrock intervals and may represent a mixed sample from multiple fractures. Phase one samples were collected from either the entire bedrock borehole or from a large, isolated bedrock zone. More than one large, isolated bedrock zone was sampled at 4 of the 10 bedrock wells (table 3) by utilizing packers installed by USGS hydrologists Paul A. Hsieh and Allen M. Shapiro. Multiple zones isolated by packers in a single bedrock well are designated in descending depth, A through D, associated with the bedrock well name (table 3). For example, FS1-A is the upper zone of bedrock well FS1. Samples were analysed for field parameters (temperature, $\mathrm{pH}$, Eh, specific conductance) and water collected for subsequent laboratory analysis of major cations and anions, selected trace metals, selected isotopes [tritium $\left({ }^{3} \mathrm{H}\right)$, uranium $\left({ }^{234} \mathrm{U},{ }^{235} \mathrm{U},{ }^{238} \mathrm{U}\right)$, radium $\left.\left({ }^{226} \mathrm{Ra},{ }^{228} \mathrm{Ra}\right)\right]$, and stable isotopes $\left[\delta^{2} \mathrm{H} / \delta^{18} \mathrm{O}\right.$, carbon $\left(\delta^{13} \mathrm{C}\right)$, sulfur $\left.\left.\left(\delta^{34} \mathrm{~S}\right)\right]\right)$.

Phase two samples are from discrete fractures in bedrock and represent the chemistry of discrete fractures (table 4). Discrete fracture samples are designated by the depth zone location (table 4). For example, the set of fractures locate at a depth of 104 feet to 116 feet below the measuring point at $\mathrm{CO} 1$ is designated as CO1-B(104-116FT) where B denotes fractures located in isolated (packed off) zone B. The cross-referencing of discrete fractures to packed-off zones allows for comparison of geochemical results between zones and discrete fractures. The purpose for collecting samples from discrete fractures was to (1) minimize borehole storage effects introduced from pumping large intervals of the bedrock borehole, as was done in phase one, (2) provide geochemical information at specific points in the flow system, and (3) compare and contrast sample results from discrete fractures with data collected from pumping boreholes intersected by multiple fractures. Geochemical samples from phase two were analyzed for the same constituents as samples from phase one, excluding sulfur-34 $\left(\delta^{34} \mathrm{~S}\right)$. Phase two samples were also analysed for tritium/helium $\left({ }^{3} \mathrm{H} / \mathrm{He}\right)$ ratio (Tolstikhin and Kamensky, 1969; Torgersen and others, 1977) — a method that allows more precise dating of waters - and radon $\left({ }^{222} \mathrm{R}\right)$ at selected wells.

Phase three samples are all from glacial drift wells (drift wells), which are either water-table wells or piezometers (table 5). The same suite of analyses done in phase two were conducted for 8 of the 15 wells; the remaining 7 samples were analyzed only for field parameters. The drift wells sampled are all located at sites with bedrock wells (the combination of multiple wells in close proximity in the same general location also is described as a well "nest"). In general, the deepest drift wells were analyzed for complete chemical analyses and the shallowest for selected field parameters.

The philosophy behind retrieving samples of groundwater was similar for all three sampling phasesthe common goal being to collect a water sample representative of the water in the surrounding geological material. The sample collection procedure varied depending on the type of material in which groundwater 
occurred, whether drift or bedrock. Regardless of the sample media, a representative sample satisfied the criteria of adequate purging of the well and stabilization of field parameters.

Bedrock boreholes, including multiple borehole zones, were pumped for only one borehole volume before collecting samples (table 6). Purging one borehole volume instead of three, a quantity recommended for sampling in unconsolidated media, ensures samples are derived from the adjacent fracture(s) close to the borehole. Overpumpage (purging more than one borehole volume) is a concern because storage properties of the bedrock are low, 1 to 2 orders of magnitude less than the drift (Allen Shapiro and Paul Hsieh, U.S. Geological Survey, written commun., February 14, 1990), and conceivably waters pumped from bedrock may be derived from a distant location. Because the intent of sampling is to determine geochemical properties at discrete locations to aid in the interpretation of the flow system, samples must reflect the local environment. Hydraulic information was collected during sampling to assess qualitatively the hydraulic properties of the bedrock. At bedrock wells with multiple packed-off zones, water levels were monitored in the adjacent zones to evaluate vertical leakage.

Glacial drift wells were pumped typically for more than three borehole volumes before collecting samples. However, some drift wells were pumped for less that three borehole volumes if the wells tapped low permeability sediments and recharge to the well was slow; examples include FS3-22, FS1-17, and K1-39. Hydraulic information was collected to determine the hydraulic properties of the drift. At sites with multiple wells in close proximity (well nest sites), water levels were monitored from wells at different depths to evaluate vertical leakage.

Bedrock wells were pumped with positive displacement pumps — a submersible, helical-drive Keck pump and a piston-driven bladder pump. When packers were used to isolate discrete fractures, as noted above, a Bennett pump (piston pump) was used. Drift wells were pumped with a Keck pump at highyielding wells and a peristaltic pump at low-yielding wells.

Field parameters were monitored according to methods outlined in Wood (1976). Field parameters include $\mathrm{pH}$, Eh (oxidation-reduction potential), specific conductance, and temperature. Dissolved oxygen was monitored only at selected sites. Field parameters were collected intermittently during pumpage to help verify that the water being collected was from aquifer water rather than water present only in the borehole. Chemical stability is attained when two or more successive measurements differ by less than the following amounts: temperature, $0.3{ }^{\circ} \mathrm{C}$; specific conductance, 5 percent; $\mathrm{pH}, 0.3$ units; Eh, 10 millivolts; and dissolved oxygen, $0.2 \mathrm{mg} / \mathrm{L}$. Physical characteristics of the water such as turbidity, color, and odor were also monitored. A sulfur odor was detected at several wells, likely indicating the presence of hydrogen sulfide.

Chemical constituents sampled are listed in table 7 along with bottle collection type, preservation procedures, and quantity collected. Samples for radiochemical isotopes and trace metals were filtered with a 0.45-micron pore size sieve using a Millipore filter plate. Samples for tritium/helium were collected under pressurized conditions in a copper tube. Discussion of the method for collecting water in copper tubes is presented in Ekwurzel and others (1994) and at the following Web site: http://water.usgs.gov/lab/3h3he/ sampling/. Other samples were collected without filtration. Radiochemical isotope and trace metal samples were preserved with ultrapure nitric acid to a $\mathrm{pH}$ below 2 to prevent precipitation of constituents. Samples for sulfur-34 $\left(\delta^{34} \mathrm{~S}\right)$ were preserved with a tablet containing 13 milligrams (mg) of mercury(II) chloride $\left(\mathrm{HgCl}_{2}\right)$ plus $100 \mathrm{mg}$ of sodium chloride $(\mathrm{NaCl})$ to prevent biochemical reactions.

In 1991, sample collection occurred at selected water table wells, piezometers, and bedrock wells (table 8). Water also was collected at the Pleasant View domestic well. Pumping and sample collection from intervals within the bedrock wells were done in the same manner as in 1990.

There were four components to the program of geochemical sampling during 1992. These were (1) sampling bedrock wells, (2) sampling overburden piezometers, (3) sampling during aquifer and tracer tests in the FSE well field, and (4) sampling low-permeability zones in the bedrock. The wells and zones pumped during 1992 are listed in table 9. 
During the period July 19 to 22, 1993, six hydraulically isolated intervals in two bedrock wells were pumped and water samples were collected for geochemical and isotopic analysis. The intervals were hydraulically isolated using inflatable packers, and a Bennett (piston) pump was used to withdraw water from the packed-off interval. The packers were inflated using pressurized nitrogen tanks. The piston pump was also driven using pressurized nitrogen tanks.

In all tested intervals, field parameters (alkalinity titrations, dissolved oxygen, $\mathrm{pH}$, specific conductance, and temperature) were measured as pumping was being conducted. Water samples were also collected for field analysis of radon concentration using portable radon analyzing equipment. At each sampling interval, water samples were collected for major cations and anions, as well as isotopes of hydrogen, oxygen, and carbon. Water samples in copper tubes were collected for ${ }^{3} \mathrm{H} / \mathrm{He}$ analysis at the Columbia University Lamont-Doherty Earth Observatory. Water samples were collected in glass ampoules for analysis of chlorofluorocarbon concentrations, and evacuated side-arm glass sampling tubes were used to collect water samples for analysis of dissolved gases by Eurybiades Busenberg (USGS Chlorofluorocarbon Laboratory, Reston, Virginia).

Water samples were collected from wells during the summers of 1995 (table 10), 1996 (table 11), and 1997 (table 12). This sampling effort focused primarily on wells screened near the water table, but also included some wells screened in the glacial drift beneath the water table (piezometers) and selected bedrock wells. The general procedures for sampling consisted of pumping at least one borehole volume and then collecting water samples using standard procedures and equipment developed by the USGS (table 13). Chlorofluorocarbon samples were collected using procedures and equipment developed at the USGS Chlorofluorocarbon Laboratory, Reston Virginia (Busenberg and Plummer, 1992). In 1996, water was collected from the bedrock wells through copper tubing using a Bennett pump. Copper tubing was used during sample collection in 1996 to identify if the type of tubing had an influence on the analysis of the concentrations of chlorofluorocarbons used from dating groundwater. Samples collected from bedrock wells in prior years used nylon tubing for sample collection.

Field water-quality parameters included temperature, $\mathrm{pH}$, specific conductivity, dissolved oxygen, and alkalinity. Methods of measurement were similar to those used in 1990. Specific conductivity and $\mathrm{pH}$ were measured with separate Orion probes, both of which also measured temperature. In some cases the probes were lowered into the water-table well or piezometer prior to sampling to record in-situ values. Dissolved oxygen was measured in the field using the Winkler titration method (Hach kit) or a Yellow Springs Instrument (YSI) self-stirring BOD probe (model 5905). Alkalinity was measured using a 0.16 normal $(N)$ sulfuric acid titration of 50-mL samples.

As part of the study of groundwater processes at the Mirror Lake site in central New Hampshire, water was collected for analysis from a domestic well (Pleasant View) in the general vicinity (southeast) of Mirror Lake and Hubbard Book in 1991. Two sample bottles were used to collect each water sample. One of the bottles was an acid-rinsed bottle; $1 \mathrm{~mL}$ of nitric acid $(7.5$ to $7.7 \mathrm{~N})$ was added after the bottle was filled with water from the well. Water collected in the second bottle was left untreated. The water samples were not filtered, and physical and chemical characteristics of the water from the wells were not measured at the time of sample collection. Thus, the water from this well was not collected according to the usual protocols used in the examination of groundwater in the vicinity of Mirror Lake. The goal was to obtain some approximation of characteristics found in a domestic well in the vicinity of Mirror Lake.

Groundwater flows to land surface in some parts of the Mirror Lake watershed (these flows are defined as seeps or springs). In 1997, groundwater was collected from two of these locations, Leeman's spring and Seep S3. Groundwater from these locations was collected to obtain additional information about the characteristics of groundwater within the Mirror Lake watershed. 


\title{
Methods of Physical, Chemical, and Isotopic Analysis
}

\author{
Methods of Analysis Used in 1983, 1984, 1986, 1987, and 1988
}

All samples collected in 1983 and 1984 were analysed by the Institute of Ecosystem Studies Laboratory for the following chemical constituents: ammonium, calcium, chloride, magnesium, nitrate, orthophosphorus, potassium, silica ( $\mathrm{asiO}_{2}$ ), sodium, and sulfate and according to methods described in Buso and others (2000). Additionally, in 1983, $\mathrm{pH}$ and specific conductance were determined using both filtered and unfiltered groundwater. The USGS National Water Quality Laboratory, Denver, Colorado, performed the following analyses on the sample collected in 1983 from the bedrock well K1: pH, specific conductance and total alkalinity using unfiltered water, and dissolved calcium, chloride, iron, magnesium, manganese, potassium, silica (as $\mathrm{SiO}_{2}$ ), sodium, and sulfate using filtered water according to methods described in Fishman and Friedman (1989). Samples collected in 1986, 1987, and 1988 were analyzed by the USGS National Water Quality Laboratory, Denver, Colorado, according to methods described in Fishman and Friedman (1989).

\section{Methods of Analysis Used in 1990, 1991, 1992, 1993, 1995, 1996, and 1997}

The method of analysis used in 1990, the unit of measurement, and the detection level for each chemical constituent are listed in table 14. Major anions and cations are reported in milligrams per liter. Trace metals are reported in micrograms per liter. Radiochemical isotopes are reported in picocuries per liter - a picocurie is defined as $3.7 \times 10^{-22}$ disintegrations per second; the approximate specific activity of 1 gram of radium in equilibrium with its disintegration. Both $\delta^{2} \mathrm{H}$ and $\delta^{18} \mathrm{O}$ are reported relative to a standard $(\delta)$ with units of parts per thousand as permil (\%o). The standard compostion for $\delta^{2} \mathrm{H}$ and $\delta^{18} \mathrm{O}$ is that of average seawater (standard mean ocean water, or SMOW). The value of $\delta^{13} \mathrm{C}$ is reported relative to a standard, Vienna Pee Dee Belemnite (VPDB), and is expressed in units of parts per thousand as permil (\%). The $\delta^{13} \mathrm{C}$ standard is $-25 \%$ VPDB; VPDB is the carbonate standard derived from the Rostrum of Belemnitella Americana of the Pee Dee Formation in South Carolina. Tritium $\left({ }^{3} \mathrm{H}\right)$ is reported in concentrations of tritium units (TU) where one TU is equal to one tritium atom in $10^{-18}$ atoms of hydrogen. The ${ }^{3} \mathrm{H} / \mathrm{He}$ ratio is reported as the ratio of tritium units and tritogenic helium. $\delta^{34} \mathrm{~S}$ is reported as permil (\%o) relative to a sulfur-32 sample of the Canyon Diablo Troilite (CDT). Field parameters, specifically alkalinity and $\mathrm{pH}$, were duplicated on 10 percent of samples to ensure accuracy of results.

Methods of analysis for isotopic analyses conducted from 1991 to 1997 were the same as in 1990. Chemical constituents were determined by analyses at the USGS Branch of Regional Research Water Research Laboratory in Reston, Virginia. In 1993, direct current plasma atomic emission spectroscopy (DCP-AES) was used for all cation determinations; ion chromatography (IC) was employed for chloride and sulfate; and an ion selective electrode and standard additions were used for fluoride. In some cases, laboratory alkalinity titrations were performed to either correct suspect field values or to obtain data for those samples in which no field alkalinity data were available. Analyses conducted by the IES laboratory followed procedures provided in Buso and others (2000): atomic-adsorption spectroscopy was used for calcium, magnesium, potassium, and sodium; ion chromatography was used for nitrate and sulfate; automated continuous colorimetry (Technicon and Alpkem instruments) was used for ammonium, chloride, and orthophosphate; and inductively coupled plasma atomic emission spectroscopy (ICP-AES) was used for silicate (silicon) as $\mathrm{SiO}_{2}$.

Note - Alkalinity, or acid neutralizing capacity (ANC), is reported in different units according to reporting by the laboratories. Therefore the tables containing these data present the data either as milligrams per liter as $\mathrm{CaCO}_{3}$, milligrams per liter as $\mathrm{HCO}_{3}^{-}$, or millequivalents per liter. The Institute for Ecosystems Studies Laboratory reported ANC in milliequivalents per liter, determined by the difference between measured cations and anions. The USGS laboratories in Denver and Reston reported alkalinity 
in milligrams per liter as $\mathrm{CaCO}_{3}$, determined from titration. Results of alkalinity titrations done at the site, as water was being collected, are reported as alkalinity in milligrams per liter as $\mathrm{HCO}_{3}^{-}$. Alkalinity in milligrams per liter as $\mathrm{CaCO}_{3}$ can be converted to milliequivalents per liter by multiplying the alkalinity value by 0.01998 . Alkalinity in milligrams per liter as $\mathrm{CaCO}_{3}$ can be converted to alkalinity in milligrams per liter as $\mathrm{HCO}_{3}^{-}$by dividing the alkalinity in milligrams per liter as $\mathrm{CaCO}_{3}$ by 0.8202 . Alkalinity in milligrams per liter as $\mathrm{HCO}_{3}^{-}$can be converted to milliequivalents per liter by multiplying the alkalinity value by 0.01639 .

\section{Measurement of Physical and Chemical Characteristics Within Wells in 1987 and 1988.}

Most of the measurements for temperature, $\mathrm{pH}$, and specific conductance at wells were made adjacent to each well as groundwater exited the well during pumping. Measurements made at the well are defined as field measurements (field parameters) to distinguish them from measurements made in the laboratory. In addition to measurements made at a well while groundwater was removed from the well, a groundwater probe was used to measure temperature, $\mathrm{pH}$, and specific conductance of groundwater within selected wells in 1987 and 1988. The probe was a Hydrolab 4031-SU sensor unit connected by a cable 100 meters (m) in length to a 4041-DU digital display unit. The sensor unit probes had the following ranges and accuracies: temperature -5 to $45^{\circ} \mathrm{C} \pm 0.02{ }^{\circ} \mathrm{C}$; $\mathrm{pH} 0$ to 14 units \pm 0.1 unit; and specific conductance 1 to 2,000 microsiemens per centimeter $(\mathrm{mS} / \mathrm{cm})$ at $25^{\circ} \mathrm{C} \pm 20$ at $25^{\circ} \mathrm{C}, 2,000$ to $20,000 \mathrm{mS} / \mathrm{cm}$ at $25^{\circ} \mathrm{C} \pm 200$ $\mathrm{mS} / \mathrm{cm}$ at $25{ }^{\circ} \mathrm{C}$, and 20,000 to $200,000 \mathrm{mS} / \mathrm{cm}$ at $25{ }^{\circ} \mathrm{C} \pm 2,000 \mathrm{mS} / \mathrm{cm}$ at $25{ }^{\circ} \mathrm{C}$. The probe is designed for use in wells at least 2 inches in diameter. Thus, some wells of smaller diameter in the Mirror Lake watershed were not included in the in situ measurement of temperature, $\mathrm{pH}$, and specific conductance.

Prior to use in the field, the $\mathrm{pH}$ sensor of the Hydrolab 4031-SU was calibrated using commercially prepared Hydrion $\mathrm{pH}$ buffers 4.0 to 7.0. The specific conductance sensor was calibrated with standards of $1,265 \mathrm{mS} / \mathrm{cm}$ at $25{ }^{\circ} \mathrm{C}$ and $265 \mathrm{mS} / \mathrm{cm}$ at $25{ }^{\circ} \mathrm{C}$. The specific conductance standards were solutions of potassium chloride whose specific conductance had been determined in the laboratory using a Yellow Springs specific conductance meter.

After calibration, the probe was used to make measurements in water-table wells, piezometers, and bedrock wells. In the case of water-table and piezometer wells, the probe was lowered until water was encountered and the depth to water was recorded; then the probe was lowered to the bottom of the well. When the probe was at the bottom of the well, all sensors were below the top of the well screen. Values of temperature, $\mathrm{pH}$, and specific conductance were read from the digital display unit, and once values were stable those data were recorded. After all values were recorded the probe was removed from the well and stored in a 1-L graduated cylinder containing distilled water. In the case of bedrock wells, the first measurements were made when the probe first entered water in the well and was completely submersed. Following the initial measurement just below the surface of the water in the wells, measurements were made at 5-m intervals to either the bottom of the well or to a depth of $100 \mathrm{~m}$ in those wells where the depth exceeded $100 \mathrm{~m}$ below the top of the well casing. It should be noted that all bedrock wells are cased through the glacial drift and are an open hole for the remainder of their depth.

\section{Results}

Physical and chemical characteristics of water measured within the casing/borehole (in situ) of selected glacial drift and bedrock wells are presented in tables 15 to 25. Physical and chemical characteristics of water measured in the field at the time of sample collection are presented in tables 26 and 27. Data obtained during the radon surveys of 1992 and 1993 are presented in table 28. Results of laboratory analyses of water collected from water-table wells, piezometers, bedrock wells, a seep, and a spring are 
presented in tables 29 to 33 ( chemical characteristics), table 34 (radiochemical isotopic characterisitics), tables 35 and 36 (stable isotope ratios of selected elements), table 37 (isotopic characteristics) and tables 38 and 39 (dissolved gases). Results for dissolved oxygen, dissolved organic carbon, and dissolved inorganic carbon for bedrock well FSE4 are presented in table 40. Water hardness data are contained in table 41.

Data for Mirror Lake are presented in table 42. Helium data are contained in table 43.

Note - Some of the piezometers are located in zones of low hydraulic conductivity (FS1-25, FS1-35, FSE-23, FSE-32, FSE-43, FSE6-51, K1-20, K1-39, R1-55). In these piezometers, some chemical characteristics of water in the vicinity of the well screen initially were related to the presence of the cement above the well screen. In cases where the water in the piezometers was collected more than once, the tables indicate where characteristics of that water changed over time and were no longer related to the presence of the cement above the well screen.

\section{References Cited}

Busenberg, Eurybiades, and Plummer, L.N., 1996, Concentrations of chlorofluorcarbons and other gases in ground water at Mirror Lake, New Hampshire, in Morganwalp, D.W., and Aronson, D.A., eds., U.S. Geological Survey Toxic Substances Hydrology Program-Proceedings of the technical meeting, Colorado Springs, Colorado, September 20-24, 1993: U.S. Geological Survey Water-Resources Investigations Report 94-4015, v. 1, p. 151-158, http://pubs.er.usgs.gov/publication/wri944015.

Busenberg, Eurybiades, and Plummer, L.N., 1992, Use of chlorofluorocarbons $\left(\mathrm{CCl}_{3} \mathrm{~F}\right.$ and $\left.\mathrm{CCl}_{2} \mathrm{~F}_{2}\right)$ as hydrologic tracers and age-dating tools - The alluvium and terrace system of central Oklahoma: Water Resources Research, v. 28, no. 9, p. 2257-2283.

Buso, D.C, Likens, G.E., and Eaton, J.S., 2000, Chemistry of precipitation, streamwater, and lakewater from the Hubbard Brook Ecosystem Study-A record of sampling protocols and analytical procedures: U.S. Department of Agriculture Forest Service, Northeastern Research Station, General Technical Report NE-275, $52 \mathrm{p}$.

Drenkard, S., Torgersen, T., Weppernig, R., Farley, K., Schlosser, P., Michel, R.L., Shapiro, A.M., and Wood, W.W. , 1996, Helium isotope analysis and tritium-helium age dating in the Mirror Lake Basin, Grafton County, New Hampshire, in Morganwalp, D.W., and Aronson, D.A., eds., U.S. Geological Survey Toxic Substances Hydrology Program-Proceedings of the technical meeting, Colorado Springs, Colorado, September 20-24, 1993: U.S. Geological Survey Water-Resources Investigations Report 94-4015, v. 1, p. 159-165. http://pubs.er.usgs.gov/publication/wri944015.

Driscoll, F.G., 1986, Groundwater and wells, 2d ed., St. Paul, Minnesota, Johnson Division, 1,089 p.

Ekwurzel, Brenda, Schlosser, Peter, Smethie, W.M., Jr., Plummer, L.N., Busenberg, Eurybiades, Michel, R.L., Weppernig, Ralf, and Stute, Martin, 1994, Dating of shallow groundwater-Comparison of the transient tracers ${ }^{3} \mathrm{H} /{ }^{3} \mathrm{He}$, chlorofluorocarbons, and ${ }^{85} \mathrm{Kr}$ : Water Resources Research, v. 30, no. 6, p. $1693-$ 1708.

Fishman, M.J., and Friedman, L.C., eds., 1989, Methods for the determination of inorganic substances in water and fluvial sediments: Techniques of Water-Resources Investigations of the United States Geological Survey, book 5, chap. A1, 545 p., http://water.usgs.gov/pubs/twri/twri5-al/.

Goode, D.J., 1998, Ground-water age and atmospheric tracers - Simulation studies and analysis of field data from the Mirror Lake site, New Hampshire: Princeton, N.J., Princeton University, Department of Civil Engineering and Operations Research, Ph.D. thesis, 194 p. 
Goode, D.J., Busenberg, Eurybiades, Plummer, L.N., Shapiro, A.M., and Vroblesky, D.A., 1999, CFC's in the unsaturated zone and in shallow ground water at Mirror Lake, New Hampshire, in Morganwalp, D.W., and Buxton, H.T., eds., U.S. Geological Survey Toxic Substances Hydrology ProgramProceedings of the technical meeting, Charleston, South Carolina, March 8-12, 1999: U.S. Geological Survey Water-Resources Investigations Report 99-4018C, v. 3, p. 809-820, http://toxics.usgs.gov/pubs/ wri99-4018/Volume3/.

Harte, P.T., 1997, Preliminary assessment of the lithologic and hydraulic properties of the glacial drift and shallow bedrock in the Mirror Lake area, Grafton County, New Hampshire: U.S. Geological Survey Open-File Report 96-654A, 56 p., http://pubs.er.usgs.gov/publication/ofr96654A.

Harte, P.T., and Winter, T.C., 1996, Factors affecting recharge to crystalline rock in the Mirror Lake area, Grafton County, New Hampshire, in Morganwalp, D.W., and Aronson, D.A., eds., U.S. Geological Survey Toxics Substances Hydrology Program-Proceedings of the technical meeting, Colorado Springs, Colorado, September 20-24, 1993: U.S. Geological Survey Water-Resources Investigations Report 94-4015, v. 1, p. 141-150, http://pubs.er.usgs.gov/publication/wri944015.

Johnson. C.D., and Dunstan, A.H., 1998, Lithology and fracture characterization from drilling investigations in the Mirror Lake area, Grafton County, New Hampshire: U.S. Geological Survey WaterResources Investigations Report 98-4183, 211 p., http://pubs.er.usgs.gov/publication/wri984183.

Kendall, C., Sklash, M.G., and Bullen, T.D., 1995, Isotope tracers of water and solute sources in catchments, in Trudgill, S.T., ed., Solute modelling in catchment systems, New York, Wiley, p. 261-303.

Lane, S.L., Flanagan, Sarah, and Wilde, F.D., 2003, Selection of equipment for water sampling (ver. 2.0): U.S. Geological Survey Techniques of Water-Resources Investigations, book 9, chap. A2, March 2003, accessed August 10, 2011, at http://pubs.water.usgs.gov/twri9A2/.

Likens, G.E., ed., 1985, An ecosystem approach to aquatic ecology-Mirror Lake and its environment: New York, Springer-Verlag, 516 p.

Likens, G.E., and Buso, D.C., 2010, Salinzation of Mirror Lake by road salt: Water, Air, and Soil Pollution, v. 205, p. 205-214.

Morganwalp, D.W., and Aronson, D.A., eds., 1996, U.S. Geological Survey Toxic Substances Hydrology Program-Proceedings of the technical meeting, Colorado Springs, Colorado, September 20-24, 1993: U.S. Geological Survey Water-Resources Investigations Report 94-4015, v. 1, 176 p., http://pubs.er.usgs.gov/publication/wri944015.

Morganwalp, D.W., and Buxton, H.T., eds., 1999, Research in characterizing fractured rock aquifers, section G of Morganwalp, D.W., and Buxton, H.T., eds., Subsurface contamination from point sources, v. 3 of U.S. Geological Survey Toxic Substances Hydrology Program-Proceedings of the technical meeting, Charleston, South Carolina, March 8-12, 1999: U.S. Geological Survey Water-Resources Investigations Report 99-4018C, p. 667-845, http://pubs.er.usgs.gov/publication/wri994018. (Abstracts of papers in section $\mathrm{G}$ are available at http://toxics.usgs.gov/pubs/wri99-4018/Volume3/index.html.)

Paillet, F.L., and Kapucu, Kemal, 1989, Fracture characterization and fracture-permeability estimates from geophysical logs in the Mirror Lake watershed, New Hampshire: U.S. Geological Survey WaterResources Investigations Report 89-4058, 47 p., http://pubs.er.usgs.gov/publication/wri894058.

Rosenberry, D.O., Bukaveckas, P.A., Buso, D.C., Likens, G.E., Shapiro, A.M., and Winter, T.C., 1999, Movement of road salt to a small New Hampshire lake: Water, Air, and Soil Pollution, v. 109, p. 179-206.

Shapiro, A.M., Hsieh, P.A., and Winter, T.C., 1995, The Mirror Lake fractured-rock research site-A multidisciplinary research effort in characterizing ground-water flow and chemical transport in fractured rock: U.S. Geological Survey Fact Sheet 138-95, 2 p., http://pubs.er.usgs.gov/publication/fs 13895.

Shapiro, A.M., 2001, Effective matrix diffusion in kilometer-scale transport in fractured crystalline rock: Water Resources Research, v. 37, no. 3, p. 507-522. 
Shapiro, A M., Hsieh, P.A., Burton, W.C., and Walsh, G.J., 2007, Integrated multi-scale characterization of ground-water flow and chemical transport in fractured crystalline rock at the Mirror Lake Site, New Hampshire, in Hyndman, D.W., Day-Lewis, F.D., and Singha, K., eds., Subsurface hydrology—Data integration for properties and processes: American Geophysical Union Geophysical Monograph Series, v. 171, p. $201-225$.

Shattuck, P.C., 1991, Shallow water-table response to precipitation and evapotranspiration in an ephemeral stream valley, Woodstock, New Hampshire: Durham, University of New Hampshire, M.S. thesis, 113 p.

Tiedeman, C.R., Goode, D.J., and Hsieh, P.A., 1997, Numerical simulation of ground-water flow through glacial deposits and crystalline bedrock in the Mirror Lake area, Grafton County, New Hampshire: U.S. Geological Survey Professional Paper 1572, 50 p., http://pubs.er.usgs.gov/publication/pp1572.

Tolstikhin, I.N., and Kamensky, I.L., 1969, Determination of groundwater age by the T- ${ }^{3} \mathrm{He}$ method: Geochemistry International, v. 6, p. 810-811.

Torgersen, T., Top, Z., Clarke, W.B., Jenkins, W.J., and Broecker, W.S., 1977, A new method for physical limnology - tritium-helium-3 ages - Results for Lakes Erie, Huron, and Ontario: Limnology and Oceanography, v. 22, p. 181-193.

Winter, T.C., 1984, Geohydrologic setting of Mirror Lake, West Thornton, New Hampshire: U.S. Geological Survey Water-Resources Investigations Report 84-4266, 61 p., http://pubs.er.usgs.gov/ publication/wri844266.

Winter, T.C., Buso, D.C., Shattuck, P.C., Harte, P.T., Vroblesky, D.A., and Goode, D.J., 2008, The effect of terrace geology on ground-water movement and on the interaction of ground water and surface water on a mountainside near Mirror Lake, New Hampshire, USA.: Hydrological Processes, v. 22, no. 1, p. $21-32$.

Winter, T.C., and Likens, G.E., eds., 2009, Mirror Lake_-Interactions among air, land, and water: Berkeley, Calif., University of California Press, 336 p.

Wood, W.W., 1976, Guidelines for the collection and field analysis of ground-water samples for selected unstable constituents: U.S. Geological Survey Techniques for Water-Resources Investigations, book 1, chap. D2, 24 p., http://pubs.usgs.gov/twri/twril-d2/.

Wood, W.W., Kraemer, T.F., and Shapiro, Allen, 2004, Radon $\left({ }^{222} \mathrm{Rn}\right)$ in ground water of fractured rocksA diffusion/ion exchange model: Ground Water, v. 42, no. 4, p. 552-567. 
Tables 


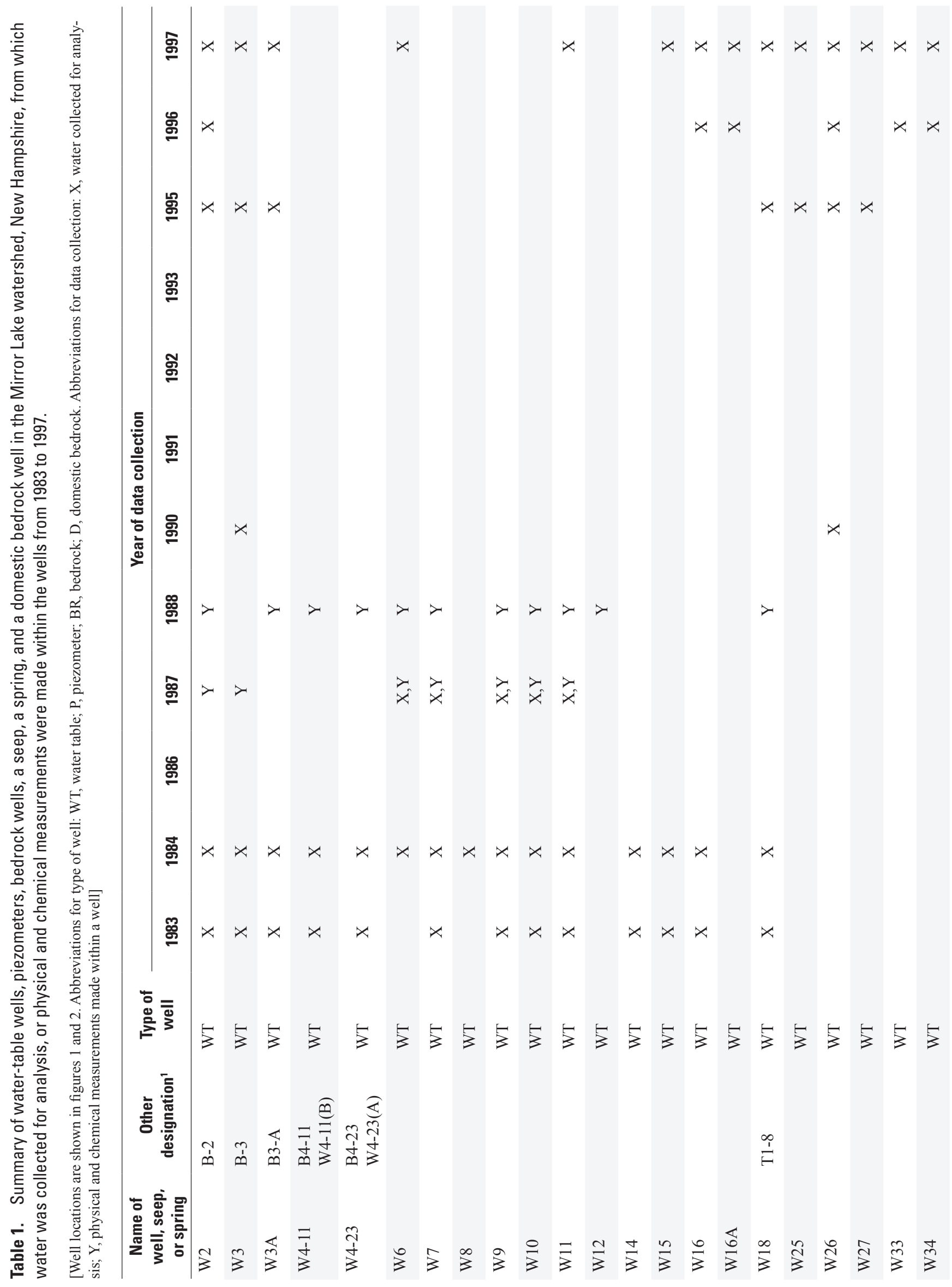


Tables 17

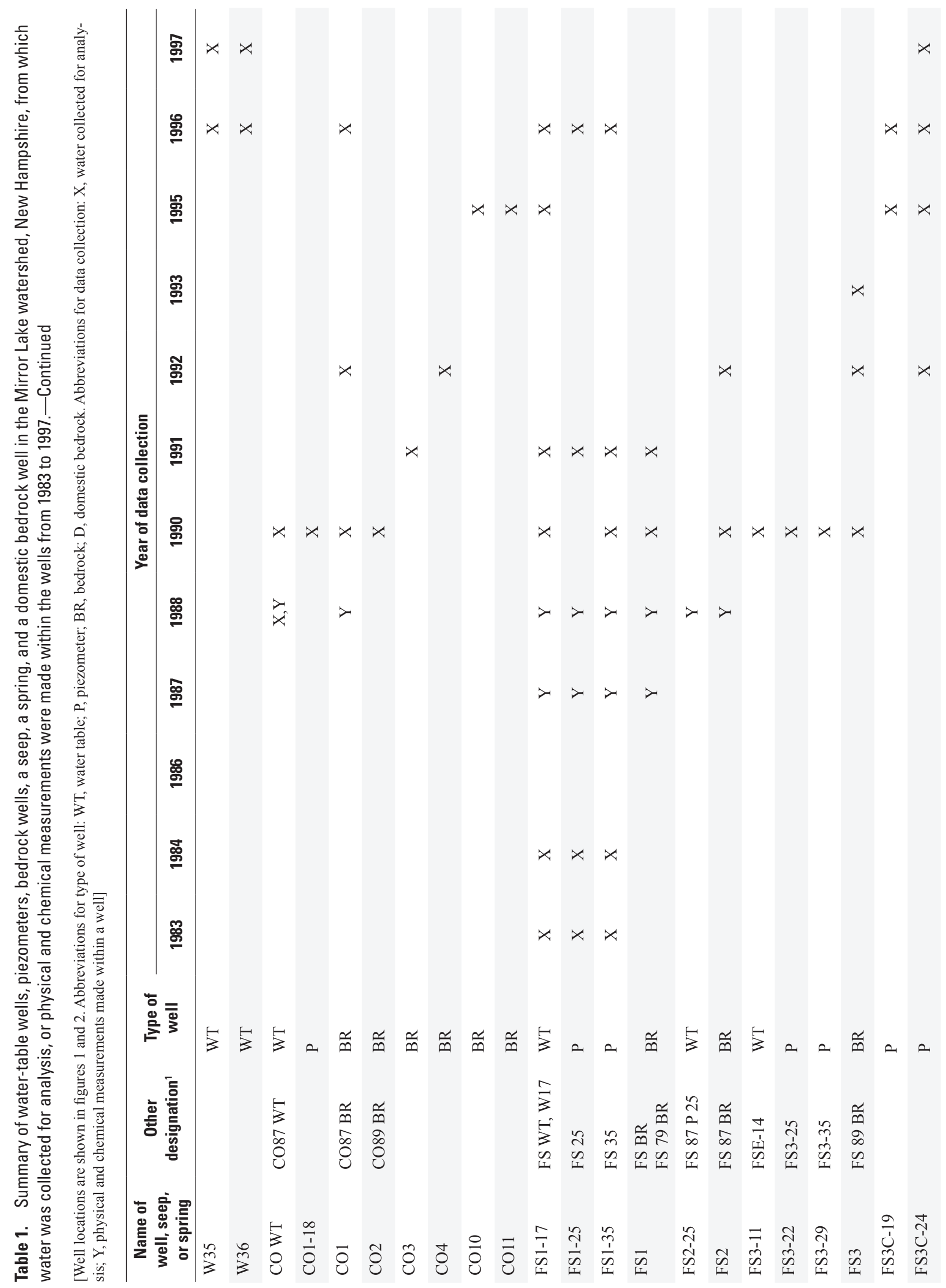




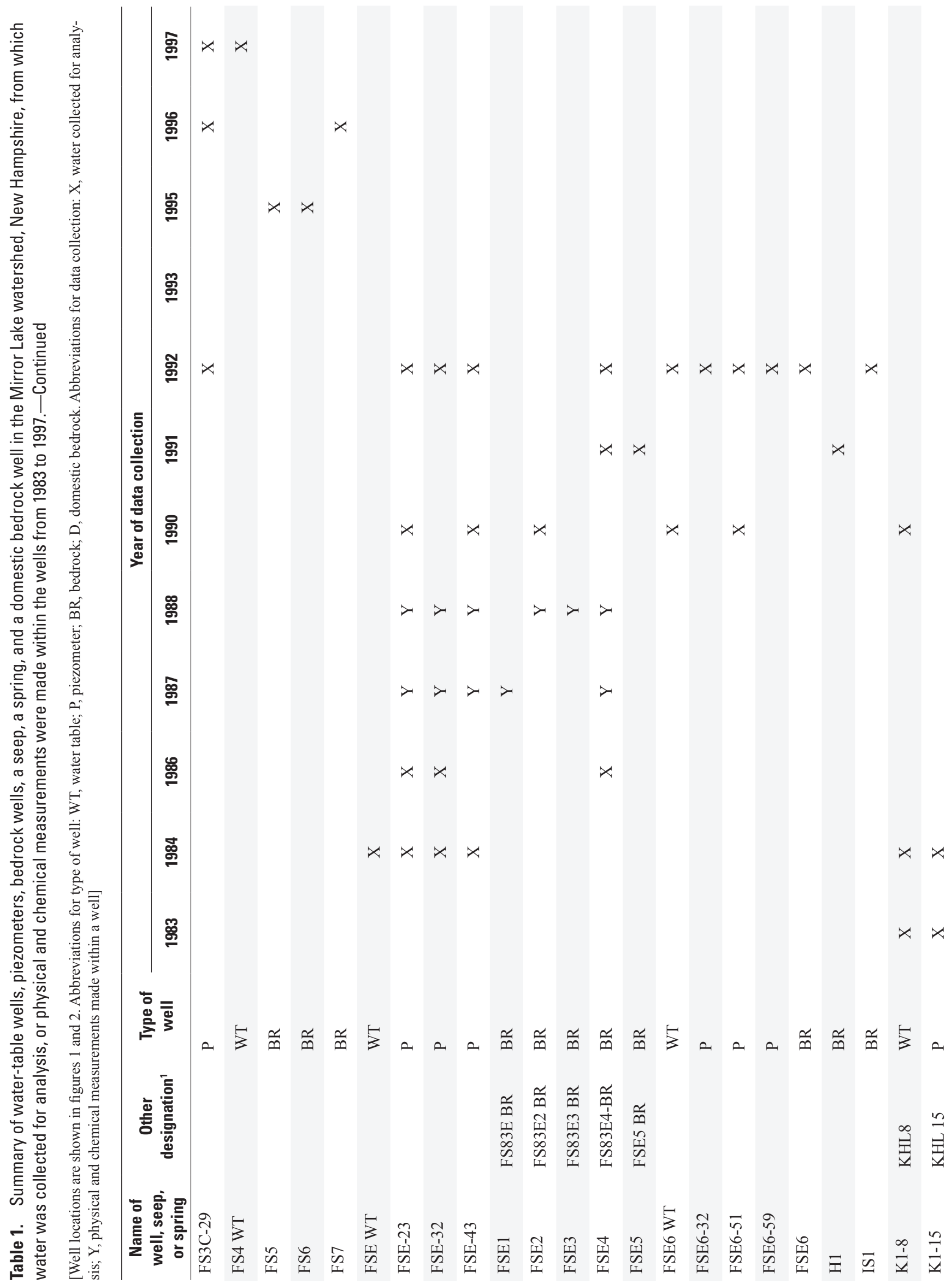




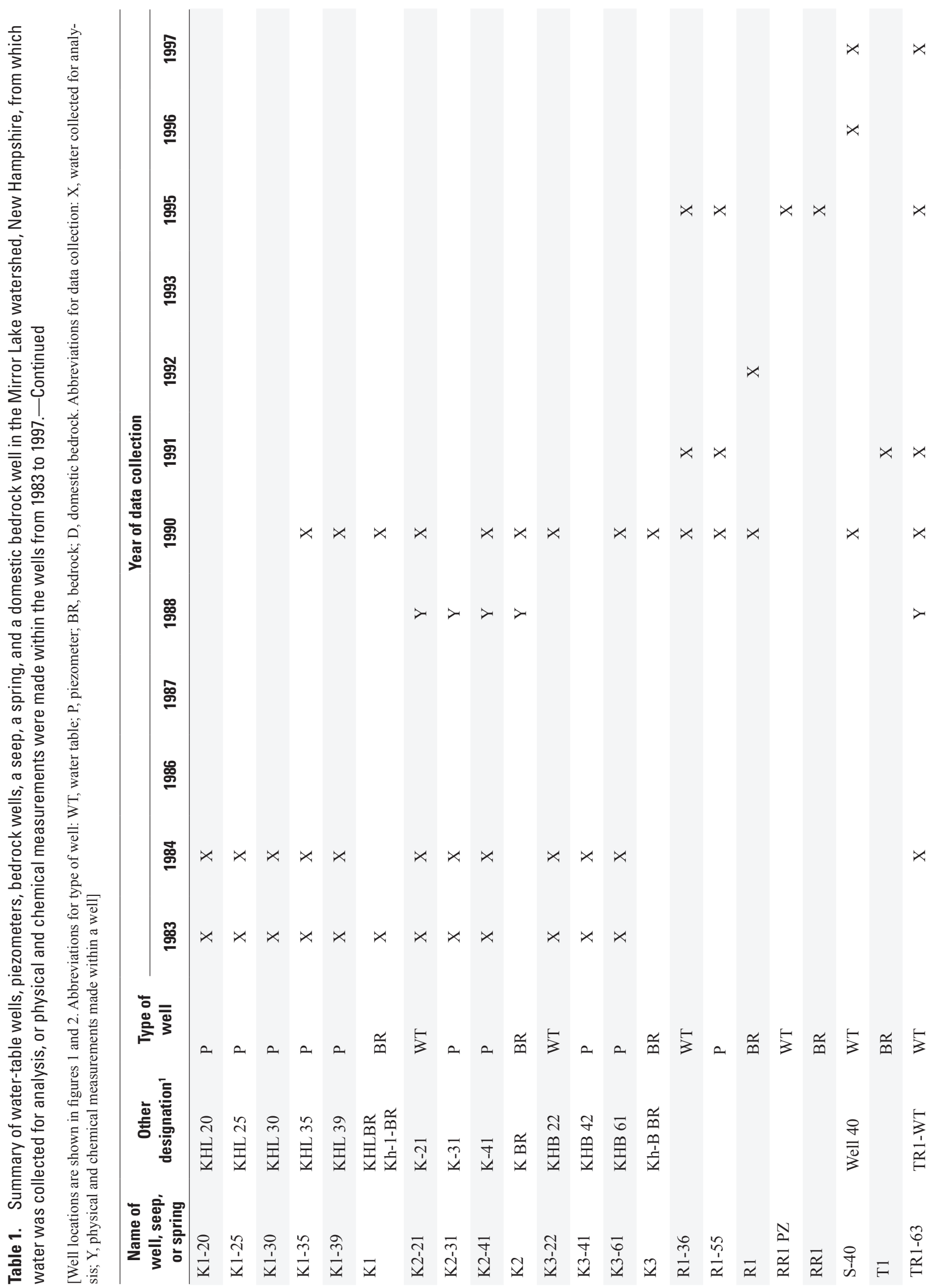




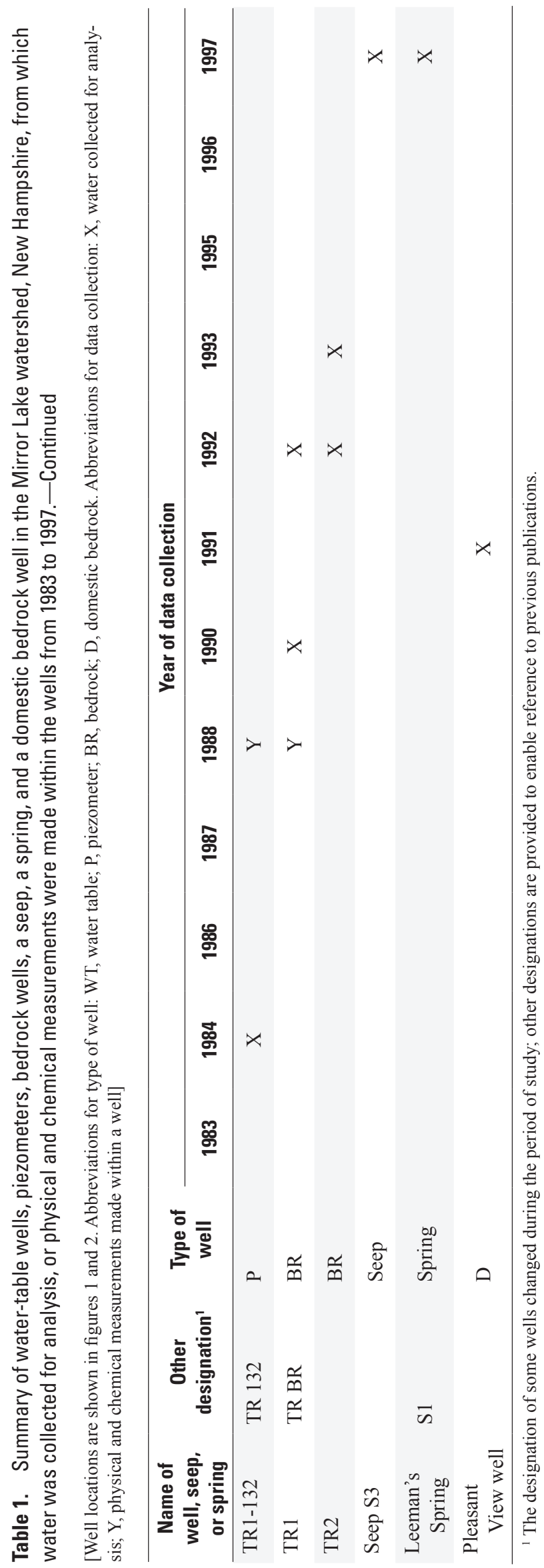


Table 2. Summary of water-table wells, piezometers, and bedrock wells in the Mirror Lake watershed, New Hampshire, including those from which water was collected for chemical analysis or measured within the well from 1983 to 1988 .

$[-$, no sample collected; ——, no measurement made $]$

\begin{tabular}{|c|c|c|c|}
\hline Name of well & $\begin{array}{l}\text { Year sampled for } \\
\text { chemical analysis }\end{array}$ & $\begin{array}{l}\text { Method of sample } \\
\text { collection }^{1}\end{array}$ & $\begin{array}{l}\text { Year of in situ } \\
\text { measurement }\end{array}$ \\
\hline W2 & 1983,1984 & B PP & 1987,1988 \\
\hline W3 & 1983, 1984 & PP PP & 1987 \\
\hline W3A & 1983,1984 & B PP & 1988 \\
\hline W4-11 & 1983,1984 & PР PP & 1988 \\
\hline W4-23 & 1983,1984 & B PP & 1988 \\
\hline W6 & 1984,1987 & B PP & 1987,1988 \\
\hline W7 & $1983,1984,1987$ & PP PP & 1987,1988 \\
\hline W8 & 1984 & PP & - \\
\hline W9 & $1983,1984,1987$ & PP PP & 1987,1988 \\
\hline W10 & 1983, 1984,1987 & PP PP & 1987, 1998 \\
\hline W11 & $1983,1984,1987$ & ВP РP PP & 1987,1988 \\
\hline $\mathrm{W} 12$ & Well was dry & - & 1988 \\
\hline W13 & Well was dry & - & - \\
\hline W14 & 1983, 1984 & BP PP & - \\
\hline W15 & 1983, 1984 & PP PP & - \\
\hline W16 & 1983, 1984 & B PP & - \\
\hline W18 & 1983,1984 & B PP & 1988 \\
\hline CO WT & 1988 & PP & 1988 \\
\hline $\mathrm{CO} 1$ & Not sampled & - & 1988 \\
\hline FS1-25 & 1983, 1984 & PP PP & 1987, 1988 \\
\hline FS1-35 & 1983, 1984 & M PP & 1987,1988 \\
\hline FS1 & Not sampled & - & 1987, 1988 \\
\hline FS1-17 & 1983,1984 & B PP & 1987, 1988 \\
\hline FS2-25 & Not sampled & - & 1988 \\
\hline $\mathrm{FS} 2$ & Not sampled & - & 1988 \\
\hline FSE WT & 1984 & PP & - \\
\hline FSE-23 & 1984, 1986 & PP PP & 1987, 1988 \\
\hline FSE-32 & 1984, 1986 & PP PP & 1987,1988 \\
\hline FSE-43 & 1984 & PP & 1987,1988 \\
\hline FSE1 & Not sampled & - & 1987 \\
\hline FSE2 & Not sampled & - & 1988 \\
\hline FSE3 & Not sampled & - & 1988 \\
\hline FSE4 & 1986 & $\mathrm{H}$ & 1987,1988 \\
\hline
\end{tabular}


Table 2. Summary of water-table wells, piezometers, and bedrock wells in the Mirror Lake watershed, New Hampshire, including those from which water was collected for chemical analysis or measured within the well from 1983 to 1988.-Continued

[—, no sample collected; —_, no measurement made]

\begin{tabular}{|c|c|c|c|}
\hline Name of well & $\begin{array}{l}\text { Year sampled for } \\
\text { chemical analysis }\end{array}$ & $\begin{array}{l}\text { Method of sample } \\
\text { collection' }\end{array}$ & $\begin{array}{l}\text { Year of in situ } \\
\text { measurement }\end{array}$ \\
\hline $\mathrm{K} 1-8$ & 1983,1984 & M PP & - \\
\hline $\mathrm{K} 1-15$ & 1983,1984 & M PP & $\longrightarrow$ \\
\hline $\mathrm{K} 1-20$ & 1983,1984 & M PP & - \\
\hline $\mathrm{K} 1-25$ & 1983,1984 & M PP & - \\
\hline $\mathrm{K} 1-30$ & 1983,1984 & M PP & $\longrightarrow$ \\
\hline $\mathrm{K} 1-35$ & 1983,1984 & M PP & $\longrightarrow$ \\
\hline K1-39 & 1983,1984 & M PP & - \\
\hline K1 & 1983 & M & - \\
\hline K2-21 & 1983, 1984 & $\mathrm{PP}$ & 1988 \\
\hline $\mathrm{K} 2-31$ & 1983,1984 & $\mathrm{~B}$ & 1988 \\
\hline K2-41 & 1983, 1984 & $\mathrm{BP}$ & 1988 \\
\hline $\mathrm{K} 2$ & Not sampled & - & 1988 \\
\hline K3-22 & 1983, 1984 & BP PP & - \\
\hline K3-41 & 1983,1984 & BP PP & - \\
\hline K3-61 & 1983,1984 & BP PР & - \\
\hline TR1-63 & 1984 & $\mathrm{~B}$ & 1988 \\
\hline TR1-132 & 1984 & B & 1988 \\
\hline TR1 & Not sampled & - & 1988 \\
\hline
\end{tabular}

${ }^{1}$ Method of sample collection: B - Bailer; BP - Bailed, pitcher pump; H - Paul Hsieh geophysical pump; M - Middleburg bladder pump; PP - Peristaltic Pump. 
Table 3. Wells and zones sampled during phase one of a groundwater study in the Mirror Lake watershed, New Hampshire, May 9 to June 4, 1990.

[C, sample zone without interval delineated]

\begin{tabular}{|c|c|c|c|}
\hline Name of well & $\begin{array}{c}\text { Sample zone } \\
\text { (feet below measuring point at } \\
\text { top of casing) or feet below land } \\
\text { surface }\end{array}$ & Constituents sampled ${ }^{1}$ & Remarks \\
\hline W3 & Water table & $\mathrm{Fp}, \mathrm{Gc}, \mathrm{Rc}, \mathrm{I} 1, \mathrm{I} 2, \mathrm{I} 3$ & \\
\hline W26 & Water table & Fp,Gc,Rc, I1, I2, I3, I5 & \\
\hline $\mathrm{CO} 1$ & B (101-209) & $\mathrm{Fp}, \mathrm{Gc}, \mathrm{Rc}, \mathrm{I} 1, \mathrm{I} 2, \mathrm{I} 3$ & \\
\hline $\mathrm{CO} 2$ & A $(25-104)$ & Fp, Gc, Rc, I1, I2, I3, I5 & No Eh \\
\hline FS1-17 & Water table & Fp,Gc,Rc, I1, I2 & No Eh \\
\hline FS1-35 & $33-35$ & $\mathrm{Fp}, \mathrm{Gc}, \mathrm{Rc}, \mathrm{I} 1, \mathrm{I} 2, \mathrm{I} 3$ & \\
\hline FS2 & A $(32-105)$ & $\mathrm{Fp}, \mathrm{Gc}, \mathrm{Rc}, \mathrm{I} 1, \mathrm{I} 2, \mathrm{I} 3, \mathrm{I} 5$ & \\
\hline FS3-22 & $20-22$ & Fp,Gc, I1, I2 & \\
\hline FS3 & A $(38-84)$ & Fp,Gc, I1, I2, I3, I5 & \\
\hline FS3 & C (197-645) & Fp,Gc, I1, I2, I3, I5 & \\
\hline FSE-23 & $21-23$ & Fp,Gc, I1, I2 & No alkalinity, Eh \\
\hline FSE-43 & $41-43$ & Fp,Gc, I1, I2, I5 & No alkalinity, Eh \\
\hline FSE2 & $\mathrm{A}(55-105)$ & Fp,Gc, I1, I2, I3, I5 & \\
\hline K2-41 & $39-41$ & Fp,Gc, I1, I2 ,I3 & \\
\hline K2 & $(55-160)$ & Fp,Gc, I1, I2, I3, I5 & \\
\hline K3-22 & Water table & Fp,Gc, I1, I2 & \\
\hline K3-61 & $59-61$ & Fp,Gc, I1, I2, I3, I5 & \\
\hline K3 & $(75-175)$ & Fp,Gc, I1, I2, I3, I5 & \\
\hline S-40 & Water table & Fp,Gc,Rc, I1, I2, I3 & \\
\hline TR1-63 & Water table & Fp,Gc, I1, I2, I3 & \\
\hline TR1 & A (177-199) & Fp,Gc, I1, I2, I3, I5 & \\
\hline TR1 & В (200-299) & Fp,Gc, I1, I2, I3, I5 & \\
\hline
\end{tabular}

${ }^{1}$ Codes:

Fp - Field parameters-Alkalinity, Eh, pH, specific conductance 
Table 3. Wells and zones sampled during phase one of a groundwater study in the Mirror Lake watershed, New Hampshire, May 9 to June 4, 1990.-Continued

[C, sample zone without interval delineated $]$

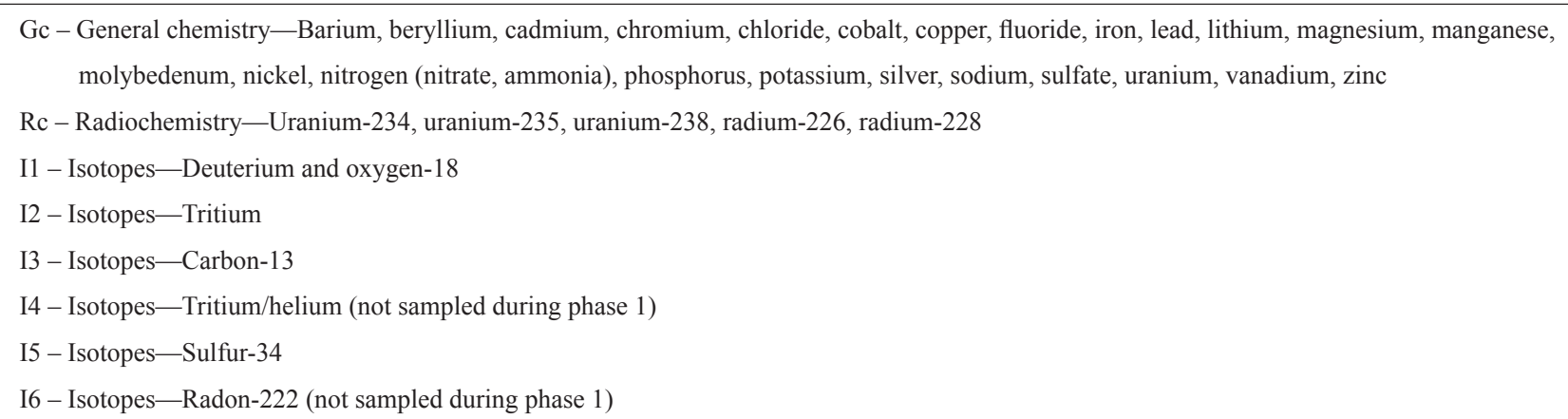

Table 4. Wells and zones sampled during phase two of a groundwater study in the Mirror Lake watershed, New Hampshire, June 21 to September 23, 1990.

\begin{tabular}{lll}
\hline Name of well & \multicolumn{1}{c}{$\begin{array}{c}\text { Sample zone } \\
\text { (feet below measuring point at } \\
\text { top of casing) }\end{array}$} & \multicolumn{1}{c}{ Constituents sampled } \\
\hline CO1 & B (104-116) & Fp, Gc, Rc, I1, I2, I3 \\
CO1 & C (409-421) & Fp, Gc, Rc, I1, I2, I3 \\
CO2 & B (163-171) & Fp, Gc, Rc, I1, I2, I3 \\
FS2 & B (133-169) & Fp, Gc, Rc, I1, I2, I3, I4, I6 \\
FS2 & C (236-251) & Fp, Gc, Rc, I1, I2, I3, I4 \\
FS3 & A (60-75) & Fp, Gc, I1, I2, I3, I4 \\
FS3 & C (365-380) & Fp, Gc, I1, I2, I3, I4, I6 \\
FS3 & C (530-545) & Fp, Gc, I1, I2, I3, I4, I6 \\
R1 & A (57-80) & Fp, Gc, I1, I2, I3, I4 \\
R1 & B (102-125) & Fp,Gc, I1, I2, I3, I4 \\
R1 & B (148-171) & Fp, Gc, I1, I2, I3, I4 \\
TR1 & A (171-190) & Fp, Gc, I1, I2, I3, I4 \\
TR1 & B (271-300) & Fp, Gc, I1, I2, I3, I4 \\
TR1 & C (299-327) & Fp, Gc, I1, I2, I3, I4 \\
\hline I 0 & \\
\hline
\end{tabular}

${ }^{1}$ Codes:

Fp - Field parameters-Alkalinity, Eh, $\mathrm{pH}$, specific conductance

Gc - General chemistry-Barium, beryllium, cadmium, chromium, chloride, cobalt, copper, fluoride, iron, lead, lithium, magnesium, manganese, molybedenum, nickel, nitrogen (nitrate, ammonia), phosphorus, potassium, silver, sodium, sulfate, uranium, vanadium, zinc

Rc - Radiochemistry-Uranium-234, uranium-235, uranium-238, radium-226, radium-228

I1 - Isotopes-Deuterium and oxygen-18

I2 - Isotopes-Tritium

I3 - Isotopes - Carbon-13

I4 - Isotopes-Tritium/helium

I5 - Isotopes - Sulfur-34 (not sampled during phase 2)

I6 - Isotopes-Radon-222 
Table 5. Wells sampled during phase three of a groundwater study in the Mirror Lake watershed, New Hampshire, November through December, 1990.

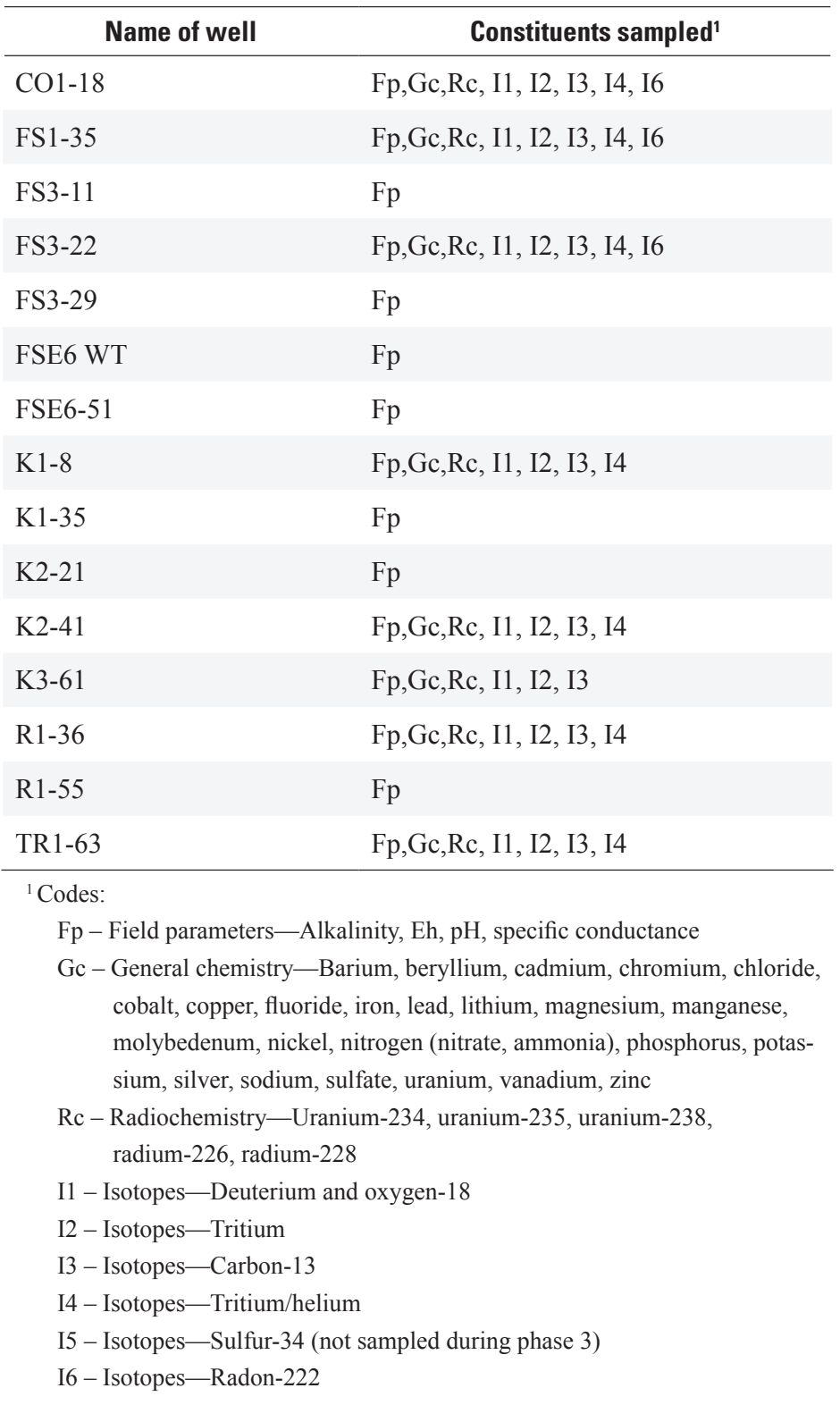




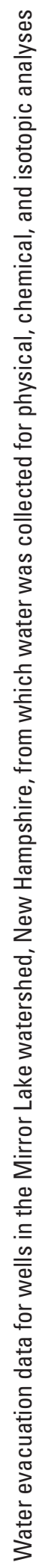

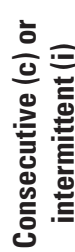

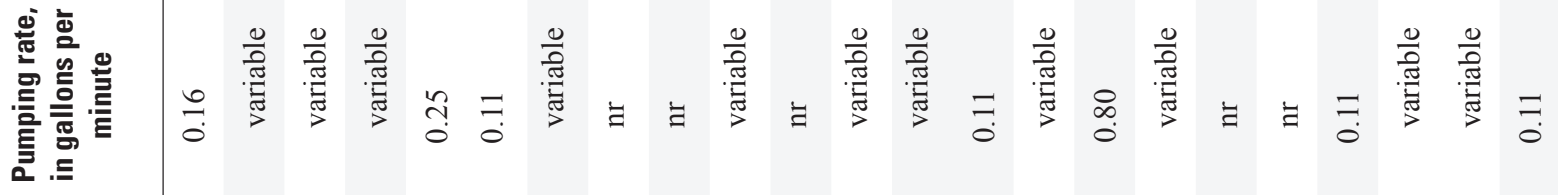

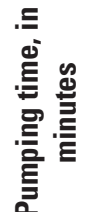

号 ¿

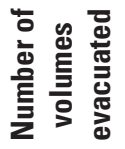

0 กூ่

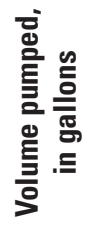

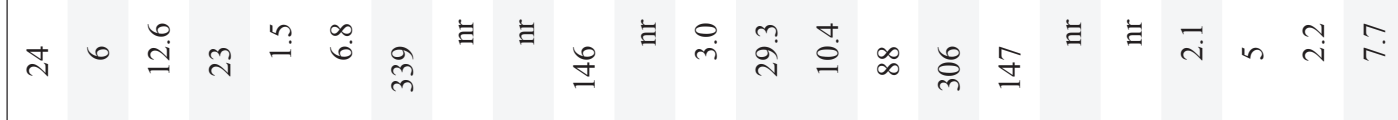

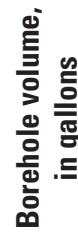

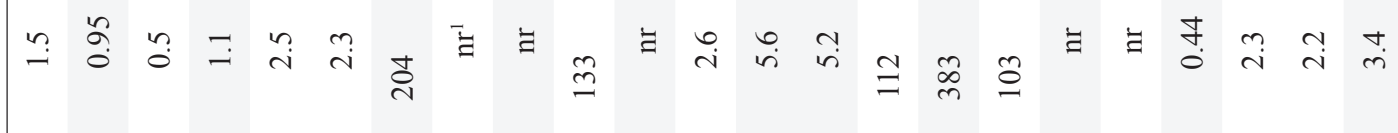

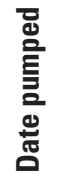

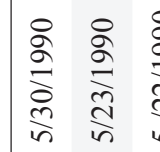

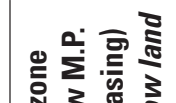

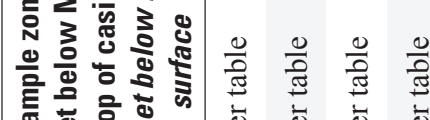

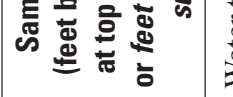

离离

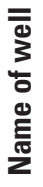

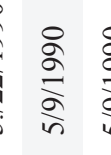

$\frac{a}{2} \frac{2}{2} \frac{2}{2}$

$\stackrel{\circ}{2}$

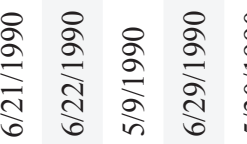

$\stackrel{\substack{2 \\ \frac{2}{n}}}{\frac{2}{2}}$

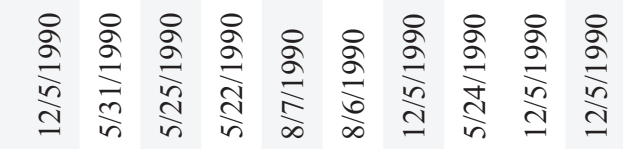




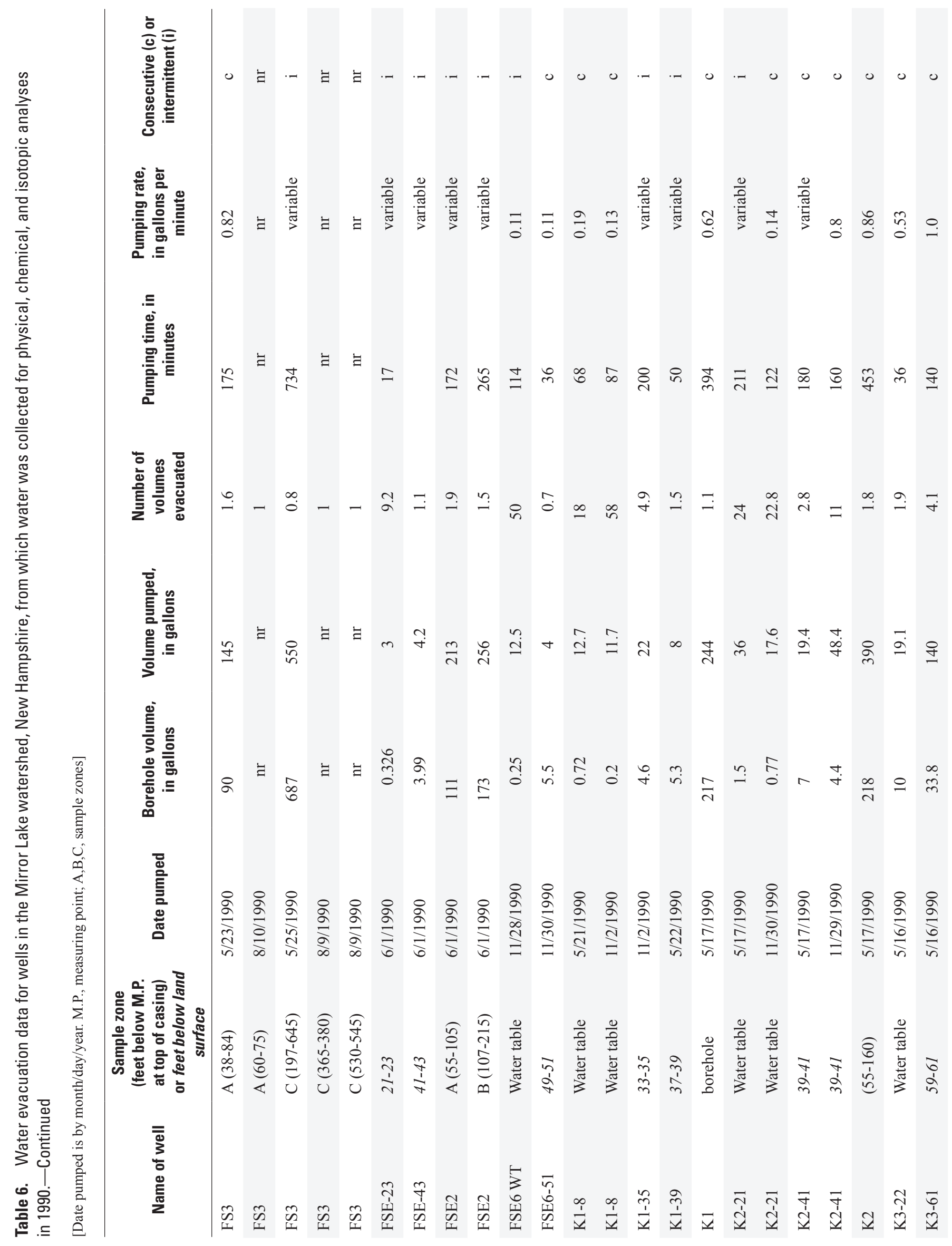




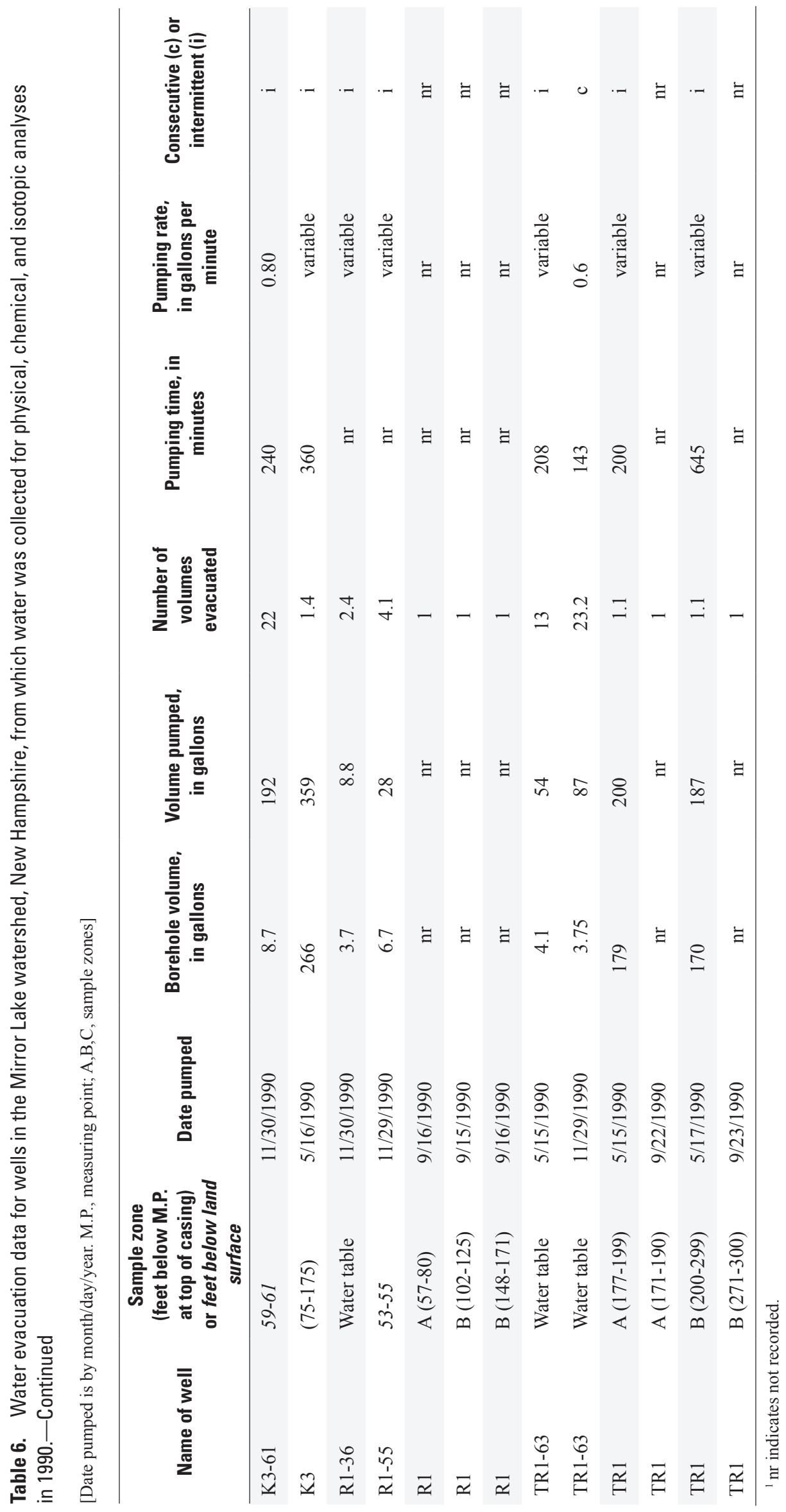


Table 7. Chemical constituents and their collection and preservation procedures for water samples collected in the Mirror Lake watershed, New Hampshire, in 1990.

[USGS, U.S. Geological Survey; - , no analytical method code associated with the constituent; mL, milliliter; L, liter]

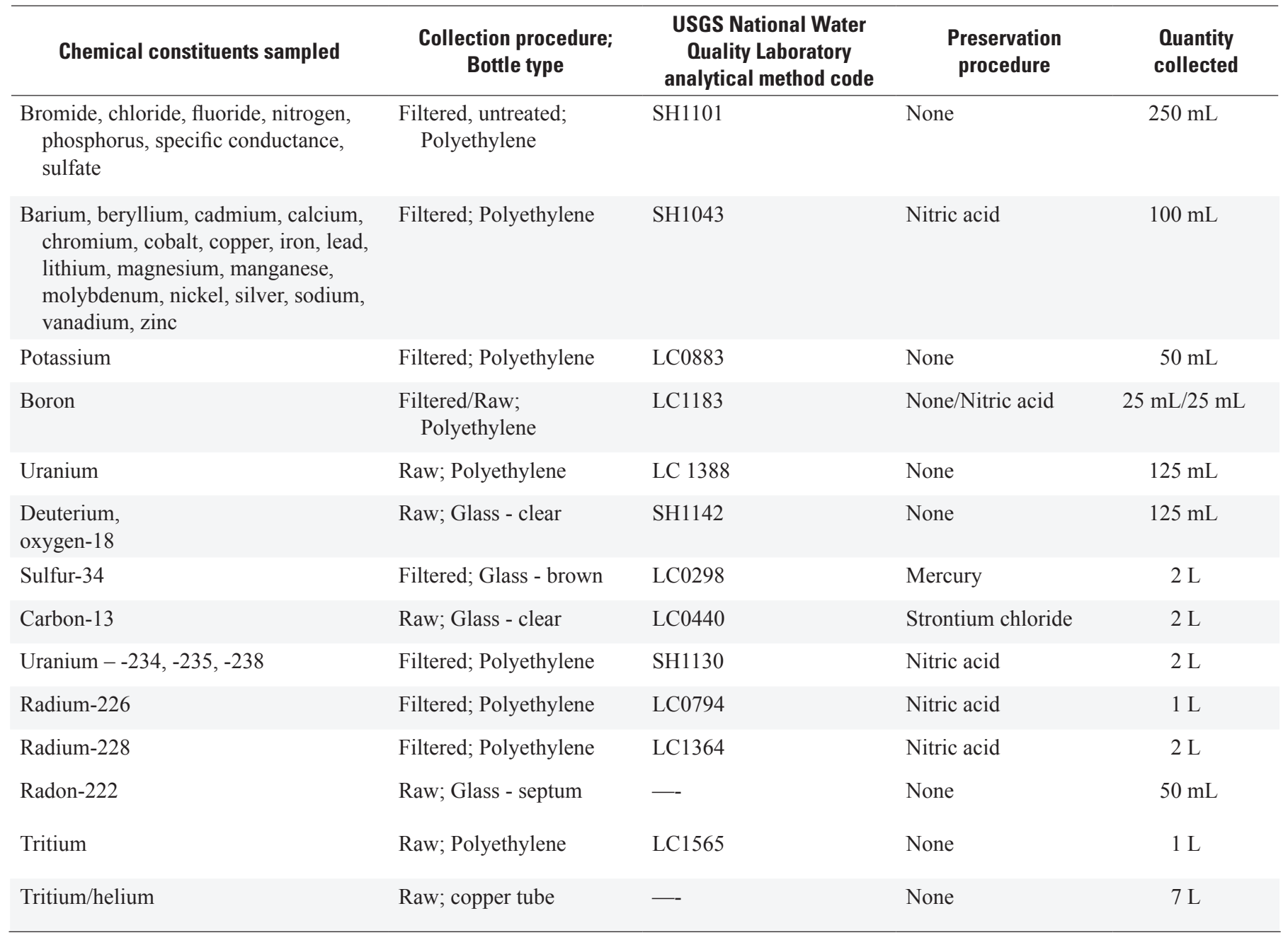


Table 8. Wells and zones sampled in the Mirror Lake watershed, New Hampshire, in 1991.

[Date of collection is by month/day/year]

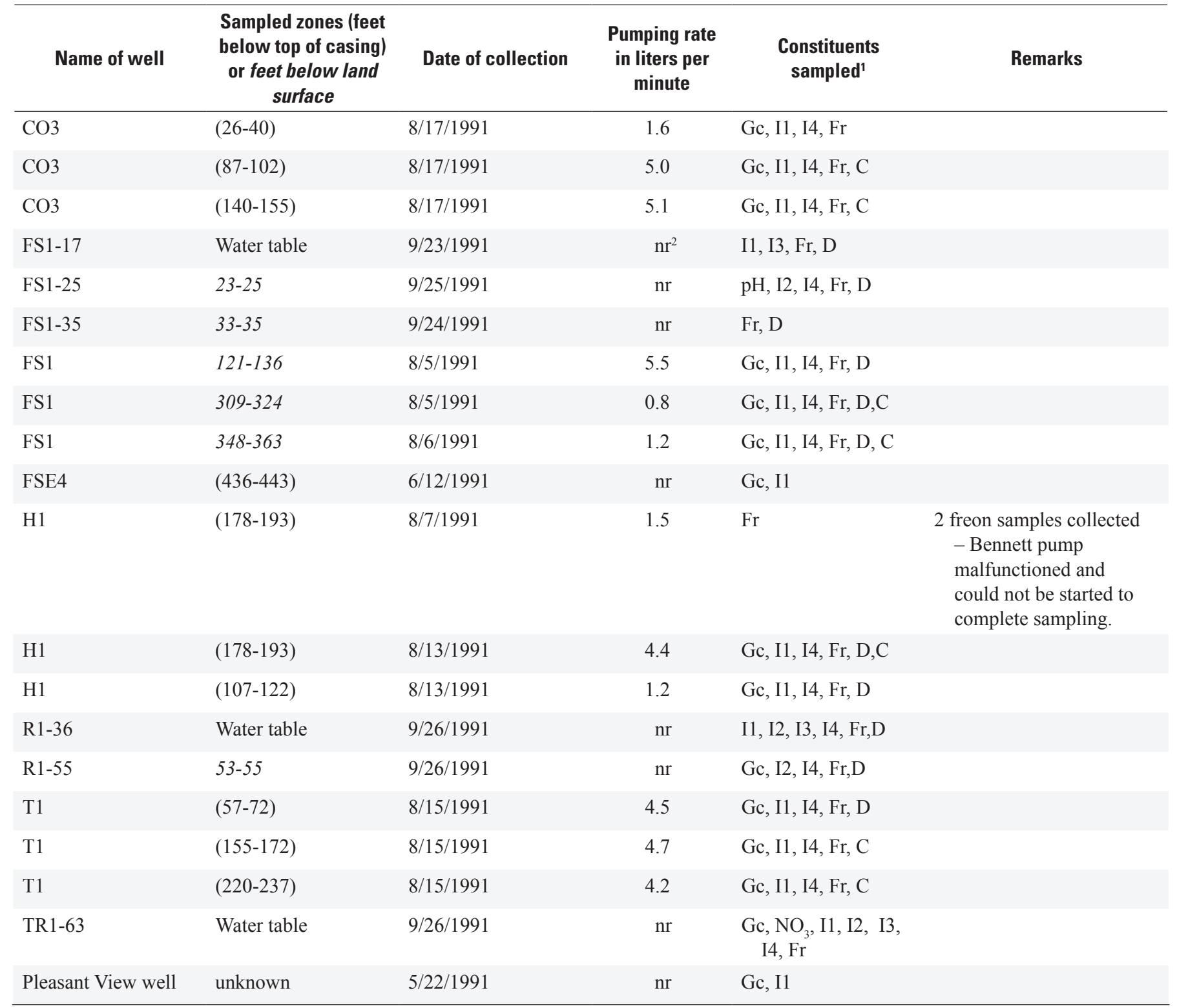

${ }^{1}$ Codes:

$\mathrm{Gc}$ - General chemistry - Alkalinity, bromide, calcium, chloride, fluoride, iron, magnesium, pH, potassium, silica as $\mathrm{SiO}^{2}$, sodium, specfic conductance, strontium, and sulfate

I1 - Isotopes-Deuterium and oxygen-18

I2 - Isotopes-Tritium

I3 - Isotopes - Carbon-13

I4 - Isotopes-Tritium/helium

Fr - Freon (Chlorofluorocarbons 11, 112, and 113)

D - Dissolved gas

$\mathrm{C}$ - Sample collected for ${ }^{14} \mathrm{C}$ analysis in the event that it was needed for age dating based on tritium presence or absence

${ }^{2} \mathrm{nr}$ indicates not recorded. 
Table 9. Wells and zones pumped or sampled (or both) in the Mirror Lake watershed, New Hampshire, in 1992 and 1993.

[Date of collection is by month/day/year; R, radon-222; $\delta^{13} \mathrm{C}$, isotope ratio of carbon-13 to carbon-12 in comparison to the isotope ratio in a standard - Vienna Pee Dee Belemnite; Mn, manganese; $\mathrm{NO}_{3}$, nitrate; $\mathrm{C}-14$, carbon- $14 ;{ }^{3} \mathrm{H}$, tritium]

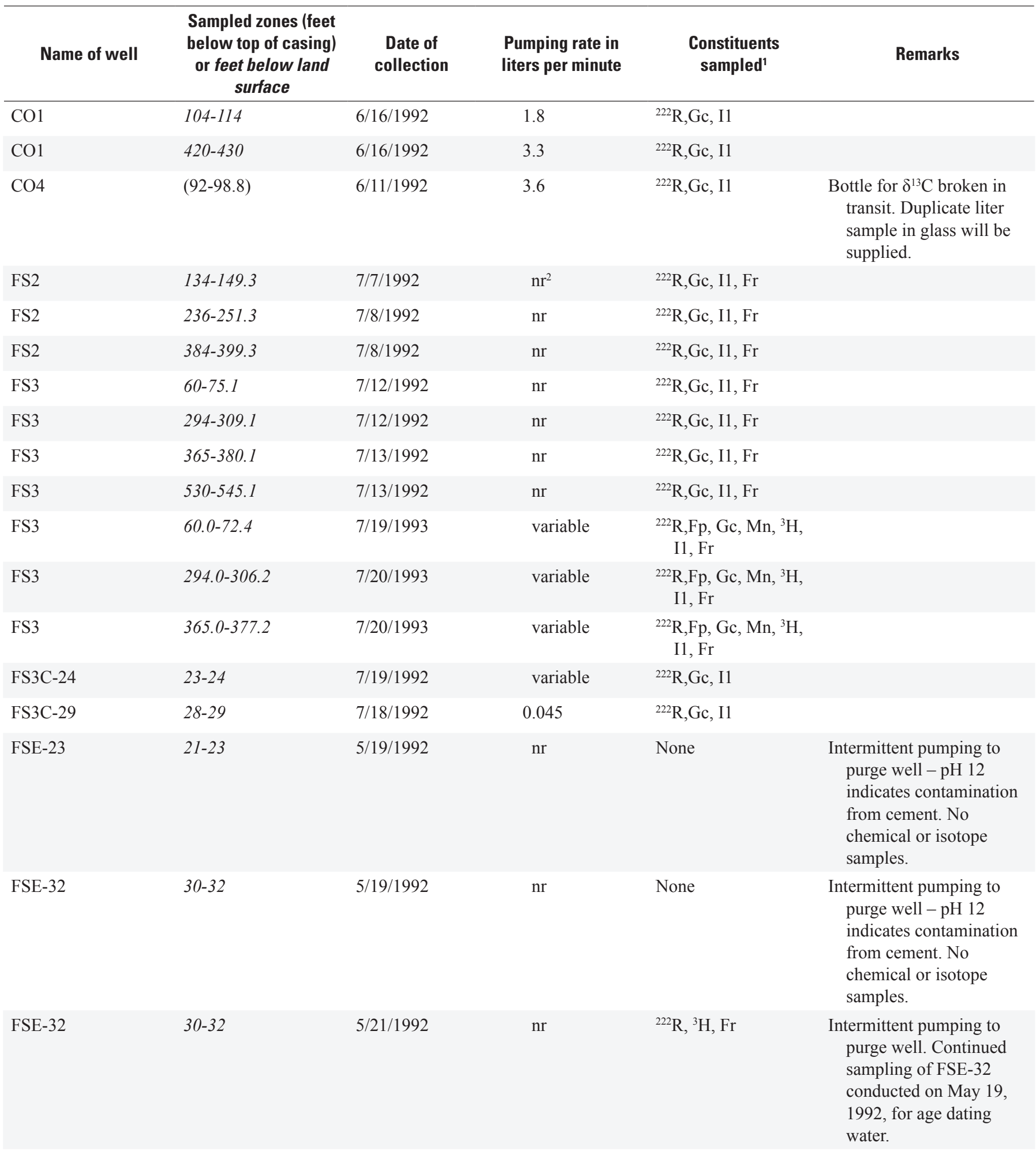


Table 9. Wells and zones pumped or sampled (or both) in the Mirror Lake watershed, New Hampshire, in 1992 and 1993. -Continued

[Date of collection is by month/day/year; R, radon-222; $\delta^{13} \mathrm{C}$, isotope ratio of carbon-13 to carbon-12 in comparison to the isotope ratio in a standard - Vienna Pee Dee Belemnite; Mn, manganese; $\mathrm{NO}_{3}$, nitrate; $\mathrm{C}-14$, carbon- $14 ;{ }^{3} \mathrm{H}$, tritium]

\begin{tabular}{|c|c|c|c|c|c|}
\hline Name of well & $\begin{array}{c}\text { Sampled zones (feet } \\
\text { below top of casing) } \\
\text { or feet below land } \\
\text { surface }\end{array}$ & $\begin{array}{l}\text { Date of } \\
\text { collection }\end{array}$ & $\begin{array}{l}\text { Pumping rate in } \\
\text { liters per minute }\end{array}$ & $\begin{array}{l}\text { Constituents } \\
\text { sampled }^{1}\end{array}$ & Remarks \\
\hline FSE-43 & $41-43$ & $5 / 19 / 1992$ & $\mathrm{nr}$ & ${ }^{3} \mathrm{H}, \mathrm{Fr}$ & $\begin{array}{l}\text { Intermittent pumping to } \\
\text { purge well - pH } 12 \\
\text { indicates contamination } \\
\text { from cement. No } \\
\text { chemical or isotope } \\
\text { samples. }\end{array}$ \\
\hline FSE4 & $(438.2-445)$ & $5 / 18 / 1992$ & 0.24 & ${ }^{222} \mathrm{R}, \mathrm{Gc}, \mathrm{I} 1, \mathrm{Fr}$ & \\
\hline FSE6 WT & $10.5-15.5$ & $5 / 20 / 1992$ & $\mathrm{nr}$ & ${ }^{222} \mathrm{R}, \mathrm{Gc}, \mathrm{I} 1$ & $\begin{array}{l}\text { Intermittent pumping to } \\
\text { purge well. Very silty } \\
\text { water. Partial sampling } \\
\text { conducted. }\end{array}$ \\
\hline FSE6-51 & $49-51$ & $5 / 20 / 1992$ & $\mathrm{nr}$ & ${ }^{222} \mathrm{R}$ & $\begin{array}{l}\text { Intermittent pumping } \\
\text { to purge well. Water } \\
\text { smelled of sewage, } \\
\text { probably from leach } \\
\text { field west of FSE-6. At } \\
\text { end of pumping, gray, } \\
\text { silty water. Only radon } \\
\text { sample taken. }\end{array}$ \\
\hline IS1 & $(400-406.8)$ & $6 / 4 / 1992$ & 4.6 & ${ }^{222} \mathrm{R}, \mathrm{Gc}, \mathrm{I} 1, \mathrm{Fr}$ & \\
\hline IS1 & $(466.5-473.3)$ & $6 / 4 / 1992$ & variable & ${ }^{222} \mathrm{R}, \mathrm{Gc}, \mathrm{I} 1, \mathrm{Fr}$ & $\begin{array}{l}\text { Pumping rate varied. } \\
\text { Sediment in water } \\
\text { causing pump to } \\
\text { clog. Partial sampling } \\
\text { conducted. }\end{array}$ \\
\hline R1 & $65-80.1$ & $7 / 14 / 1992$ & $\mathrm{nr}$ & ${ }^{222} \mathrm{R}, \mathrm{Gc}, \mathrm{I} 1, \mathrm{Fr}$ & \\
\hline R1 & $110-125.1$ & $7 / 14 / 1992$ & $\mathrm{nr}$ & ${ }^{222} \mathrm{R}, \mathrm{Gc}, \mathrm{I} 1, \mathrm{Fr}$ & \\
\hline R1 & $147-162.1$ & $7 / 15 / 1992$ & $\mathrm{nr}$ & ${ }^{222} \mathrm{R}, \mathrm{Gc}, \mathrm{I1}, \mathrm{Fr}$ & \\
\hline R1 & $480-495.1$ & 7/15/1992 & $\mathrm{nr}$ & ${ }^{222} \mathrm{R}, \mathrm{Gc}, \mathrm{I} 1, \mathrm{Fr}$ & \\
\hline TR1 & $170-190$ & $6 / 30 / 1992$ & 0.69 & $\begin{array}{c}{ }^{222} \mathrm{R}, \mathrm{Gc}, \mathrm{NO}_{3}, \mathrm{I} 1, \\
\delta^{13} \mathrm{C}, \mathrm{Fr}, \mathrm{G} 1\end{array}$ & Water is slightly silty. \\
\hline
\end{tabular}


Table 9. Wells and zones pumped or sampled (or both) in the Mirror Lake watershed, New Hampshire, in 1992 and 1993. - Continued

[Date of collection is by month/day/year; R, radon-222; $\delta^{13} \mathrm{C}$, isotope ratio of carbon-13 to carbon-12 in comparison to the isotope ratio in a standard - Vienna Pee Dee Belemnite; Mn, manganese; $\mathrm{NO}_{3}$, nitrate; $\mathrm{C}-14$, carbon- $14 ;{ }^{3} \mathrm{H}$, tritium]

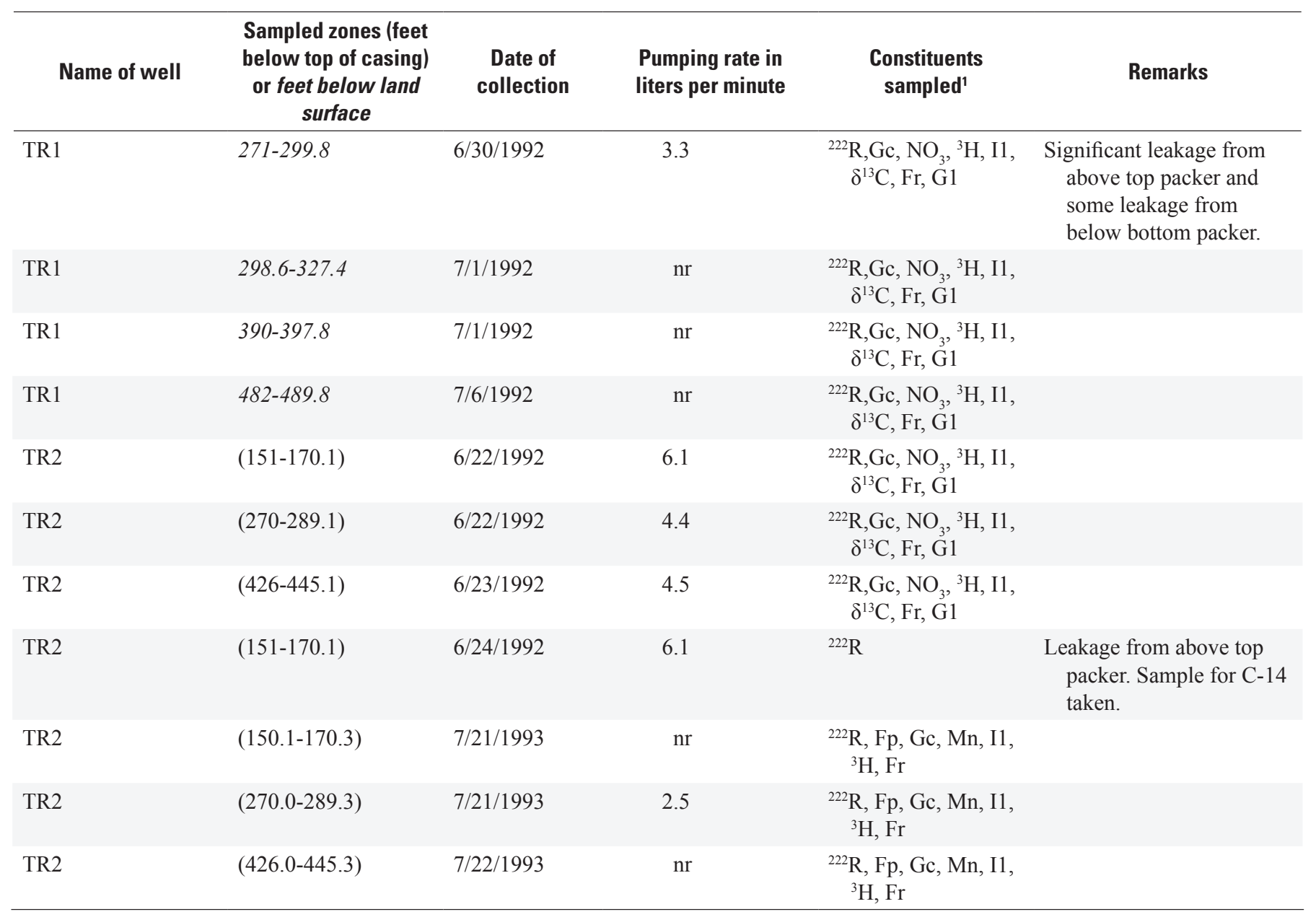

${ }^{1}$ Codes:

Fr - Freon (Chlorofluorocarbons 11, 112, and 113)

Fp - Field parameters - Temperature, $\mathrm{pH}$, specific conductance, dissolved oxygen, alkalinity

G1 - Dissolved gases - nitrogen, argon, carbon dioxide, methane

$\mathrm{Gc}$ - General chemistry - Alkalinity, bromide, calcium, chloride, fluoride, iron, magnesium, pH, potassium, silica as $\mathrm{SiO}^{2}$, sodium, specfic conductance, strontium, and sulfate

I1 - Isotopes-Deuterium and oxygen-18

${ }^{2} \mathrm{nr}$ indicates not recorded. 
Table 10. Wells and zones sampled in the Mirror Lake watershed, New Hampshire, in 1995.

[Date of collection is by month/day/year; NA, not applicable; - - not available; Sp. Cond., specific conductance; ${ }^{\circ} \mathrm{C}$, degrees Celsius; L/min; liters per minute; $\mu \mathrm{S} / \mathrm{cm}$, microsiemens per centimeter]

\begin{tabular}{|c|c|c|c|c|c|}
\hline Name of well & $\begin{array}{c}\text { Sampled zone } \\
\text { (feet below top } \\
\text { of casing), or feet } \\
\text { below land surface }\end{array}$ & $\begin{array}{l}\text { Date of } \\
\text { collection }\end{array}$ & $\begin{array}{l}\text { Pumping rate } \\
\text { in liters per } \\
\text { minute }\end{array}$ & $\begin{array}{l}\text { Constituents } \\
\text { sampled }^{1}\end{array}$ & Remarks \\
\hline W3 & Water table & $6 / 23 / 1995$ & 0.1 & $\mathrm{Fr}, \mathrm{Fp}, \mathrm{Gc}, \mathrm{I} 1, \mathrm{I} 2$ & $\begin{array}{l}\text { Pumped } 4 \text { hours. Pumping rate varied } \\
\text { between } 0.07 \text { and } 0.22 \mathrm{~L} / \mathrm{min} \text {. } \\
\text { Downhole temperature } 6.8^{\circ} \mathrm{C} \text {. }\end{array}$ \\
\hline W3A & Water table & $6 / 23 / 1995$ & 0.2 & Fr, Fp, Gc,I1,I2, I3 & $\begin{array}{l}\text { Pumping rate varied, mostly around } \\
0.2 \text { to } 0.28 \mathrm{~L} / \mathrm{min} \text {. Pumped } \\
3.75 \text { hours. Downhole temperature } \\
9.7^{\circ} \mathrm{C} \text {. }\end{array}$ \\
\hline W26 & Water table & $6 / 21 / 1995$ & 0.1 & Fr, Fp, Gc,I1, I2 & $\begin{array}{c}\text { Flow rate ranged between } 0.1 \text { and } \\
0.17 \mathrm{~L} / \mathrm{min} \text {. Pumped } 4.25 \text { hours. } \\
\text { Downhole temperature } 6.5^{\circ} \mathrm{C} \text {. }\end{array}$ \\
\hline W26 & Water table & $8 / 16 / 1995$ & - & $\mathrm{Gc}$ & $\begin{array}{l}\text { Field parameters unavailable. Sample } \\
\text { taken for comparison with analysis } \\
\text { to be conducted by D.A. Vroblesky } \\
\text { (USGS, Columbia, S.C.). }\end{array}$ \\
\hline W27 & Water table & $7 / 16 / 1995$ & 0.05 & Fr, Fp,Gc,I1,I2, I3 & Pumped 7 hours. \\
\hline $\mathrm{CO} 11$ & $(342.6-356.1)$ & 8/17/1995 & 1.1 & $\mathrm{Fp}, \mathrm{Gc}, \mathrm{I} 1, \mathrm{I} 2, \mathrm{I} 3$ & $\begin{array}{l}\text { Slight drop in } \mathrm{pH} \text { and } \mathrm{Sp} \text {. Cond. } \\
\text { during sampling. At start } \\
\text { of sampling } \mathrm{pH}=8.03, \mathrm{Sp} \text {. } \\
\text { Cond. }=420 \mu \mathrm{S} / \mathrm{cm} \text {. }\end{array}$ \\
\hline FS1-17 & Water table & $7 / 18 / 1995$ & 0.05 & Fr, Fp,Gc,I1,I2, I3 & Intermittent pumping over 5 hours. \\
\hline FS3C-19 & $18-19$ & $7 / 14 / 1995$ & 0.05 & Fr,Fp,Gc,I1,I2, I3 & $\begin{array}{l}\text { Pumping over } 2 \text { days, each day at } \\
\text { approximately constant rate. }\end{array}$ \\
\hline FS3C-24 & $23-24$ & $7 / 15 / 1995$ & 0.1 & $\mathrm{Fr}, \mathrm{Fp}, \mathrm{Gc}, \mathrm{I} 1, \mathrm{I} 2, \mathrm{I} 3$ & Pumped 4 hours. \\
\hline FS5 & $(200.4-218.0)$ & $6 / 8 / 1995$ & 2.8 & Fp, Gc, I1,I2, I3 & \\
\hline FS5 & $(142.0-155.5)$ & 6/9/1995 & 1.8 & Fp,Gc,I1,I2, I3 & \\
\hline FS5 & $(70.0-83.5)$ & 6/9/1995 & 0.32 & $\mathrm{Fp}, \mathrm{Gc}, \mathrm{I} 1, \mathrm{I} 2, \mathrm{I} 3$ & $\begin{array}{l}\text { Alkalinity titration not conducted } \\
\text { in the field. Drop in } \mathrm{pH} \text { at end of } \\
\text { sampling }(\mathrm{pH}=7.7) \text {, during last hour } \\
\text { of pumping. }\end{array}$ \\
\hline
\end{tabular}


Table 10. Wells and zones sampled in the Mirror Lake watershed, New Hampshire, in 1995.-Continued

[Date of collection is by month/day/year; NA, not applicable; - - not available; Sp. Cond., specific conductance; ${ }^{\circ} \mathrm{C}$, degrees Celsius; $\mathrm{L} /$ min; liters per minute; $\mu \mathrm{S} / \mathrm{cm}$, microsiemens per centimeter]

\begin{tabular}{|c|c|c|c|c|c|}
\hline Name of well & $\begin{array}{l}\text { Sampled zone } \\
\text { (feet below top } \\
\text { of casing), or feet } \\
\text { below land surface }\end{array}$ & $\begin{array}{l}\text { Date of } \\
\text { collection }\end{array}$ & $\begin{array}{c}\text { Pumping rate } \\
\text { in liters per } \\
\text { minute }\end{array}$ & $\begin{array}{l}\text { Constituents } \\
\text { sampled }^{1}\end{array}$ & Remarks \\
\hline FS6 & $44.0-53.5$ & $8 / 12 / 1995$ & 5.0 & $\mathrm{Fp}, \mathrm{Gc}, \mathrm{I} 1, \mathrm{I} 2$ & $\begin{array}{l}\text { First } 15 \text { minutes of pumping, } \mathrm{pH} 8.4 \text {, } \\
\text { Sp. Cond. } 150 \mu \mathrm{S} / \mathrm{cm} \text {. Later, appear } \\
\text { to draw water from overburden. } \\
\text { Field parameters and samples reflect } \\
\text { water drawn at later time. }\end{array}$ \\
\hline R1-36 & Water table & $7 / 10 / 1995$ & 0.3 & $\mathrm{Fr}, \mathrm{Fp}, \mathrm{Gc}, \mathrm{I} 1, \mathrm{I} 2, \mathrm{I} 3$ & $\begin{array}{l}\text { Pumped } 3.5 \text { hours. Downhole } \\
\text { temperature } 5.0^{\circ} \mathrm{C} \text {. }\end{array}$ \\
\hline $\mathrm{R} 1-55$ & $53-55$ & $7 / 11 / 1995$ & 0.05 & $\mathrm{Fr}, \mathrm{Fp}, \mathrm{I} 1, \mathrm{I} 2, \mathrm{I} 3$ & $\begin{array}{l}\text { pH rises throughout sampling. } \\
\text { High } \mathrm{pH} \text { indicative of cement } \\
\text { contamination. Samples will not be } \\
\text { submitted for analysis because they } \\
\text { will not be indicative of forma- } \\
\text { tion waters. Pumped } 11 \text { hours. } \\
\text { Downhole temperature } 5.6^{\circ} \mathrm{C} \text {. }\end{array}$ \\
\hline RR1 PZ & Water table & $8 / 21 / 1995$ & 0.74 & $\mathrm{Fr}, \mathrm{Fp}, \mathrm{Gc}, \mathrm{I} 1, \mathrm{I} 2, \mathrm{I} 3$ & $\begin{array}{l}\mathrm{pH} \text { and } \mathrm{Sp} \text {. Cond. rise during last } \\
15 \text { minutes of pumping }(\mathrm{pH}=7.00 \text {, } \\
\text { Sp. Cond. }=615 \mu \mathrm{S} / \mathrm{cm}) \text {. Water } \\
\text { degassing in discharge line. }\end{array}$ \\
\hline RR1 & $(582.5-596.0)$ & $8 / 18 / 1995$ & 2.7 & Fp,Gc,I1,I2, I3 & $\begin{array}{l}\text { Significant degassing of water; looks } \\
\text { like seltzer! Unable to perform } \\
\text { alkalinity titration with } 0.16 \mathrm{~N} \\
\text { sulfuric acid. }\end{array}$ \\
\hline
\end{tabular}

${ }^{1}$ Codes:

Fr - Freon (Chlorofluorocarbons 11, 112, and 113)

Fp - Field parameters - Temperature, $\mathrm{pH}$, specific conductance, dissolved oxygen, alkalinity

$\mathrm{Gc}$ - General Chemistry-Alkalinity, aluminum, bromide, calcium, chloride, fluoride, iron, magnesium, manganese, nitrate, $\mathrm{pH}$, potassium, silica as $\mathrm{SiO}_{2}$, sodium, specfic conductance, strontium, and sulfate

I1 - Isotopes-Deuterium and oxygen-18

I2 - Isotopes-Tritium

I3 - Isotopes - Carbon-13 
Table 11. Wells sampled in the Mirror Lake watershed, New Hampshire, in 1996.

[Date of collection is by month/day/year]

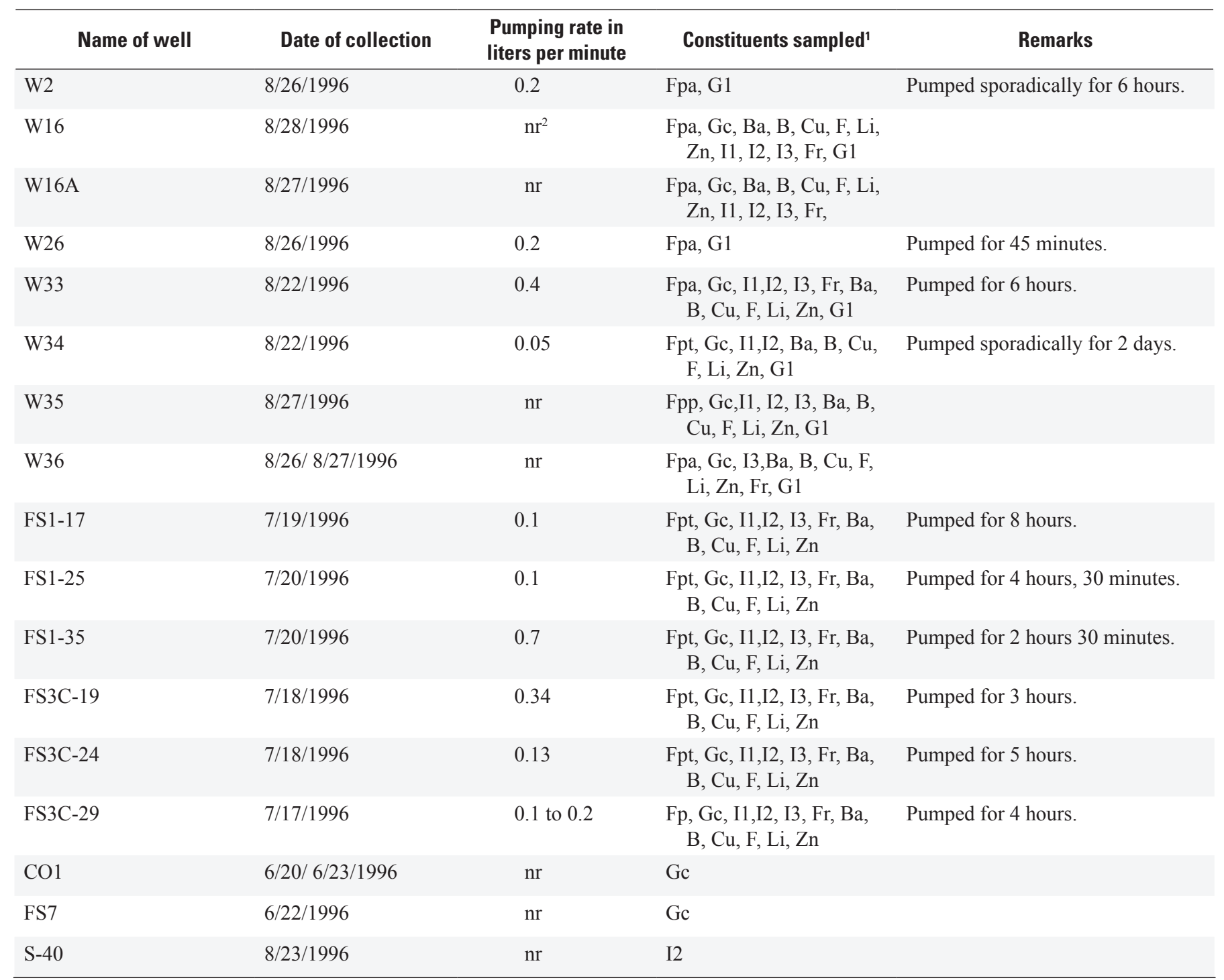

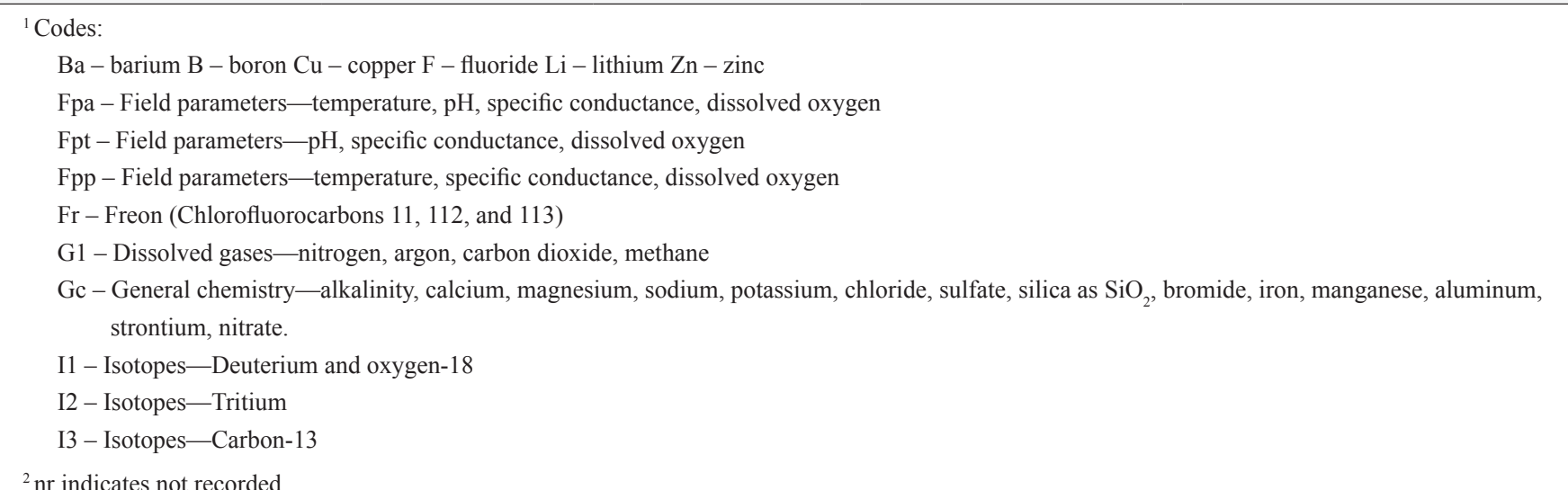


Table 12. Wells and zones, a seep, and a spring sampled in the Mirror Lake watershed, New Hampshire, in 1997.

[Date of collection is by month/day/year; *, not pumped, flowing spring]

\begin{tabular}{|c|c|c|c|c|}
\hline Name of well & $\begin{array}{c}\text { Sampled zone, or } \\
\text { feet below land } \\
\text { surface }\end{array}$ & $\begin{array}{l}\text { Date of } \\
\text { collection }\end{array}$ & $\begin{array}{l}\text { Pumping rate in } \\
\text { liters per minute }\end{array}$ & Constituents sampled ${ }^{1}$ \\
\hline W2 & Water table & 6/7/1997 & 0.07 & Fpa,Gc,I1,I2, I3, G1 \\
\hline W3 & Water table & $7 / 14 / 1997$ & 0.26 & Fpa,Gc,I1, I2,I3, G1 \\
\hline W3A & Water table & $7 / 14 / 1997$ & 0.09 & Fpa,Gc,I1,I2, I3.G1 \\
\hline W6 & Water table & $7 / 26 / 1997$ & 0.07 & Fpa,Gc,I1,I2, I3, G1 \\
\hline W11 & Water table & $7 / 25 / 1997$ & 0.2 & Fpa,Gc, I1, I2, I3, G1 \\
\hline W15 & Water table & $7 / 28 / 1997$ & 0.03 & Fpa,Gc,I1, I2, I3, G1 \\
\hline W16 & Water table & $7 / 13 / 1997$ & 0.08 & Fpa,Gc,I1, I2, I3, G1 \\
\hline W16A & Water table & $7 / 12 / 1997$ & 0.09 & FpO,Gc,I1, I2, I3, G1 \\
\hline W18 & Water table & $6 / 26 / 1997$ & 0.07 & Fpa,Gc,I1, I2, I3, G1 \\
\hline W25 & Water table & 7/13/1997 & 0.09 & Fpa,Gc,I1, I2, I3, G1 \\
\hline W26 & Water table & $6 / 8 / 1997$ & 0.08 & Fpa,Gc,I1, I2, I3, G1 \\
\hline W27 & Water table & 6/19/1997 & 0.11 & Fpa,Gc,I1, I2, G1 \\
\hline W33 & Water table & 7/7/1997 & 0.15 & Fpa, I1, I2, I3, G1 \\
\hline W34 & Water table & $6 / 10 / 1997$ & 0.06 & Fpa,Gc, I1, I2, I3, G1 \\
\hline W35 & Water table & $7 / 11 / 1997$ & 0.03 & Fpa,I1, I2, G1 \\
\hline W36 & Water table & $6 / 17 / 1997$ & 0.1 & Fpa,Gc,I1, I2, I3, G1 \\
\hline FS3C-24 & $23-24$ & $6 / 12 / 1997$ & 0.11 & Fpa,Gc,I1, I2, I3, G1 \\
\hline FS3C-29 & $28-29$ & $6 / 11 / 1997$ & 0.04 & Fpa,Gc,I1, I2, I3 \\
\hline FS4 WT & Water table & 7/8/1997 & 0.06 & Fpa,Gc,I1, I2, I3, G1 \\
\hline S-40 & Water table & $7 / 25 / 1997$ & 0.05 & Gc,I1, I2, I3, G1 \\
\hline TR1-63 & Water table & $6 / 25 / 1997$ & 0.15 & Fpa,Gc,I1, I2, I3, G1 \\
\hline Seep S3 & Water table & 8/7/1997 & 0.07 & Fpa,Gc,I1, I2, I3 \\
\hline Leeman's Spring & Water surface & 8/6/1997 & $*$ & Fpa,Gc,I1, I2, I3, G1 \\
\hline
\end{tabular}

\footnotetext{
${ }^{1}$ Codes:

Fpa - Field parameters - temperature, $\mathrm{pH}$, specific conductance, dissolved oxygen

$\mathrm{FpO}$ - Field parameters - temperature, $\mathrm{pH}$, specific conductance

$\mathrm{Gc}$ - General chemistry - alkalinity, calcium, magnesium, sodium, potassium, chloride, sulfate, silica as $\mathrm{SiO}_{2}$, bromide, fluoride, iron, manganese, aluminum, strontium, nitrate, barium, boron, chromium, cobalt, copper, lead, lithium, nickel, strontium, vanadium, zinc

I1 - Isotopes-Deuterium and oxygen-18

I2 - Isotopes - Tritium

I3 - Isotopes - Carbon-13

G1 - Dissovled gases - nitrogen, argon, carbon dioxide, methane
} 
Table 13. Procedures and equipment used for sample collection from water-table wells and piezometers in the Mirror Lake watershed, New Hampshire, in 1995, 1996, and 1997.

[USGS, U.S. Geological Survey; —, not applicable; L, liter; mL, milliliter; oz, ounce]

\begin{tabular}{|c|c|c|c|}
\hline Step & Procedures and Parameters & Equipment & Remarks \\
\hline 1 & $\begin{array}{l}\text { Measure water level and total well } \\
\text { length }\end{array}$ & Electric tape & Compute volume of water in well \\
\hline 3 & Purge well of at least 1 well volume & - & $\begin{array}{l}\text { Monitor pH, specific conductance temperature, } \\
\text { and dissolved oxygen; collect discharge for } \\
\text { volume measurements; intermittent water } \\
\text { level measurements }\end{array}$ \\
\hline 4 & Tritium & 1-L polyethylene bottle & Overflow at least 1 volume \\
\hline 5 & Carbon isotopes & $\begin{array}{l}\text { 1-L brown or clear glass bottle with } \\
\text { polyseal cap }\end{array}$ & $\begin{array}{l}\text { Overflow at least } 1 \text { volume; small air bubble } \\
\text { at top }\end{array}$ \\
\hline 8 & Deuterium and oxygen-18 & 2-oz glass bottle with polyseal cap & No air bubble \\
\hline 9 & Dissolved gases & $\begin{array}{l}200-\mathrm{mL} \text { clear glass bottles with } \\
\text { rubber septum }\end{array}$ & $\begin{array}{l}\text { Duplicate samples; no air bubble; store on } \\
\text { ice and express mail to USGS Reston } \\
\text { Chlorofluorcarbon laboratory }\end{array}$ \\
\hline 10 & Sulfur hexafluoride & $\begin{array}{l}\text { 1-L clear glass bottle with polyseal } \\
\text { cap }\end{array}$ & $\begin{array}{l}\text { No air bubble, store on ice and express mail to } \\
\text { USGS Reston Chlorofluorcarbon laboratory }\end{array}$ \\
\hline 11 & Chlorofluorocarbons & 75-mL clear glass ampules & $\begin{array}{l}\text { Collect and seal in ultra-pure apparatus } \\
\text { provided by USGS Reston } \\
\text { Chlorofluorcarbon laboratory; 3-6 samples }\end{array}$ \\
\hline
\end{tabular}


Table 14. Analytical methods and reporting procedures for samples collected in the Mirror Lake watershed, New Hampshire, in 1990.

$[\mathrm{pH},-\log (\mathrm{H}+)$; mmhos/cm, micromhos per centimeter; $\mathrm{mg} / \mathrm{L}$, milligrams per liter; $\mu \mathrm{g} / \mathrm{L}$, micrograms per liter; \%, parts per thousand of deuterium or oxygen-18; piC/L, picocuries per liter; Tu, tritium units; - , no data available; ICP, inductively-coupled plasma emission spectroscopy]

\begin{tabular}{|c|c|c|c|}
\hline Constituent & Analytical method & Unit of measurement & Detection level \\
\hline $\mathrm{pH}$ & Electrometry & $\mathrm{pH}$ & - \\
\hline Specific conductance & Electrometry & $\mu \mathrm{mhos} / \mathrm{cm}$ & 1 \\
\hline Alkalinity & Titrimetry, electrometric & $\mathrm{mg} / \mathrm{L}$ as $\mathrm{Ca} \mathrm{CO}_{3}$ & - \\
\hline $\begin{array}{l}\text { Barium, bromide, calcium, } \\
\text { magnesium, sodium, silica as } \mathrm{SiO}_{2}\end{array}$ & Dissolved, atomic emission, ICP, direct & $\mathrm{mg} / \mathrm{L}$ & 0.1 \\
\hline Fluoride & Ion chromatography & $\mathrm{mg} / \mathrm{L}$ & 0.01 \\
\hline Potassium & Dissolved, atomic absorption, direct & $\mathrm{mg} / \mathrm{L}$ & 0.01 \\
\hline Uranium & $\begin{array}{l}\text { Dissolved, extract, laser-induced phos- } \\
\text { phorimetry }\end{array}$ & $\mu \mathrm{g} / \mathrm{L}$ & 0.01 \\
\hline Deuterium & Dissolved, protium, mass spectrometry & $\%$ & - \\
\hline Oxygen-18 & Dissolved, mass spectrometry & $\%$ & - \\
\hline Sulfur-34 & Sulfate precipitate, mass spectrometry & $\%$ & - \\
\hline Uranium-234 & Dissolved, alpha spectrometry-speciation & $\mathrm{pCi} / \mathrm{L}$ & 0.1 \\
\hline Uranium-235 & Dissolved, alpha spectrometry-speciation & $\mathrm{pCi} / \mathrm{L}$ & 0.1 \\
\hline Tritium & Dissolved, liquid scintillation & $\mathrm{Tu}$ & 1 \\
\hline Tritium/helium & - & ratio & - \\
\hline
\end{tabular}


Table 15. In situ temperature, $\mathrm{pH}$, and specific conductance of groundwater within the casing or borehole of selected wells measured in the Mirror Lake watershed, New Hampshire, July 1987.

[Date of measurement is by month/day/year; Forest Service Station, Hubbard Brook Experimental Forest, United State Department of Agriculture Forest Service Northern Research Station; ${ }^{\circ} \mathrm{C}$, degrees Celsius; $\mu \mathrm{S} / \mathrm{cm} @ 25{ }^{\circ} \mathrm{C}$, microsiemens per centimeter at 25 degrees Celsius]

\begin{tabular}{|c|c|c|c|c|c|}
\hline Name of well & Date of measurement & Temperature, in ${ }^{\circ} \mathrm{C}$ & $\mathrm{pH}$ & $\begin{array}{c}\text { Specific } \\
\text { conductance, in } \\
\mu \mathrm{S} / \mathrm{cm} @ 25^{\circ} \mathrm{C}\end{array}$ & Remarks \\
\hline W7 & $7 / 8 / 1987$ & 22.0 & 7.1 & 45 & \multirow{3}{*}{$\begin{array}{l}\text { Wells in area of } \\
\text { outflow from } \\
\text { Mirror Lake into } \\
\text { groundwater. }\end{array}$} \\
\hline W9 & 7/8/1987 & 18.5 & 6.2 & 17 & \\
\hline W10 & 7/8/1987 & 10.2 & 7.8 & 29 & \\
\hline W3 & $7 / 10 / 87$ & 11.1 & 5.4 & $\wedge 1$ & \multirow{4}{*}{$\begin{array}{l}\text { Wells in west } \\
\text { drainage basin } \\
\text { north of Forest } \\
\text { Service Station. }\end{array}$} \\
\hline FS1-17 & $7 / 10 / 87$ & 7.3 & 10.0 & 39 & \\
\hline FS1-25 & $7 / 10 / 87$ & 7.1 & 12.5 & 1,748 & \\
\hline FS1-35 & $7 / 10 / 87$ & 7.9 & 12.5 & 5,280 & \\
\hline W11 & 7/7/1987 & 8.0 & 5.4 & 12 & \multirow{5}{*}{$\begin{array}{l}\text { Wells in west drain- } \\
\text { age basin east of } \\
\text { Forest Service } \\
\text { Station in vicinity } \\
\text { of acid deposition } \\
\text { experiments. }\end{array}$} \\
\hline FSE-23 & $7 / 7 / 1987$ & 8.2 & 12.8 & 1,684 & \\
\hline FSE-32 & $7 / 7 / 1987$ & 9.5 & 13.0 & 6,230 & \\
\hline FSE-43 & $7 / 7 / 1987$ & 10.0 & 13.2 & 7,820 & \\
\hline FSE4 & $7 / 7 / 1987$ & 8.6 & 6.8 & 659 & \\
\hline
\end{tabular}

${ }^{1 \wedge}$, indicates value out of range - specific conductance sensor of probe likely not fully immersed. 
Table 16. Vertical variation of in situ temperature, $\mathrm{pH}$, and specific conductance of groundwater in the Mirror Lake watershed, New Hampshire, within bedrock wells FS1 (sampled July 10, 1987) and FSE1 (sampled July 7, 1987).

$\left[{ }^{\circ} \mathrm{C}\right.$, degrees Celsius; $\mu \mathrm{S} / \mathrm{cm} @ 25^{\circ} \mathrm{C}$, microsiemens per centimeter at 25 degrees Celsius $]$

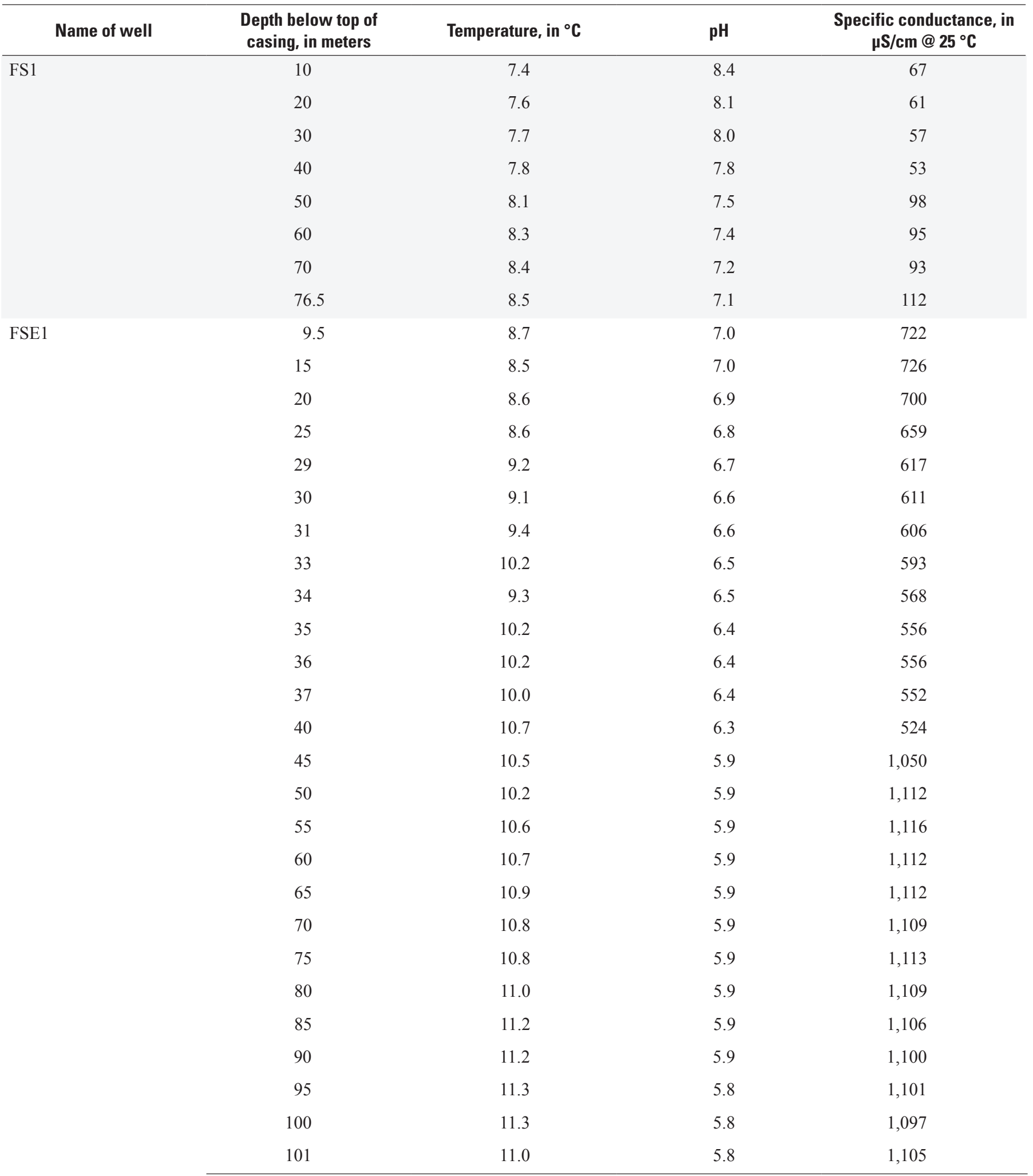


Table 17. In situ temperature, $\mathrm{pH}$, and specific conductance of groundwater measured in selected wells in the Mirror Lake watershed, New Hampshire, July 19, 1988.

$\left[{ }^{\circ} \mathrm{C}\right.$, degrees Celsius; $\mu \mathrm{S} / \mathrm{cm} @ 25^{\circ} \mathrm{C}$, microsiemens per centimeter at 25 degrees Celsius $]$

\begin{tabular}{lccc}
\hline Name of well & Temperature, in ${ }^{\circ} \mathbf{C}$ & $\mathbf{p H}$ & $\begin{array}{c}\text { Specific conductance, } \\
\text { in } \mathbf{\mu S} / \mathbf{c m} @ \mathbf{~ 2 5}^{\circ} \mathbf{C}\end{array}$ \\
\hline W2 & 9.7 & 6.8 & 74 \\
W3A & 10.6 & 6.7 & 23 \\
W4-11 & 10.8 & 6.8 & $\wedge 1$ \\
W4-23 & 7.5 & 6.9 & 97 \\
W6 & 8.2 & 8.0 & 73 \\
W7 & 22.7 & 6.7 & 32 \\
W9 & 19.5 & 6.1 & 30 \\
W10 & 8.8 & 6.8 & 84 \\
W11 & 8.4 & 7.3 & 38 \\
W12 & 14.5 & 6.8 & $\wedge$ \\
FS1-17 & 14.6 & 6.1 & 49 \\
W18 & 9.1 & 7.7 & 55 \\
CO WT & 7.9 & 6.3 & $\wedge$ \\
\hline
\end{tabular}

${ }^{1 \wedge}$, indicates value out of range - specific conductance sensor of probe likely not fully immersed. 
Table 18. Vertical variation of in situ temperature, $\mathrm{pH}$, and specific conductance of groundwater in the Mirror Lake watershed, New Hampshire, in bedrock well FS1 and adjacent piezometers FS1-25 and FS1-35, July 20, 1988.

$\left[{ }^{\circ} \mathrm{C}\right.$, degrees Celsius; $\mu \mathrm{S} / \mathrm{cm} @ 25^{\circ} \mathrm{C}$, microsiemens per centimeter at 25 degrees Celsius; —, not applicable]

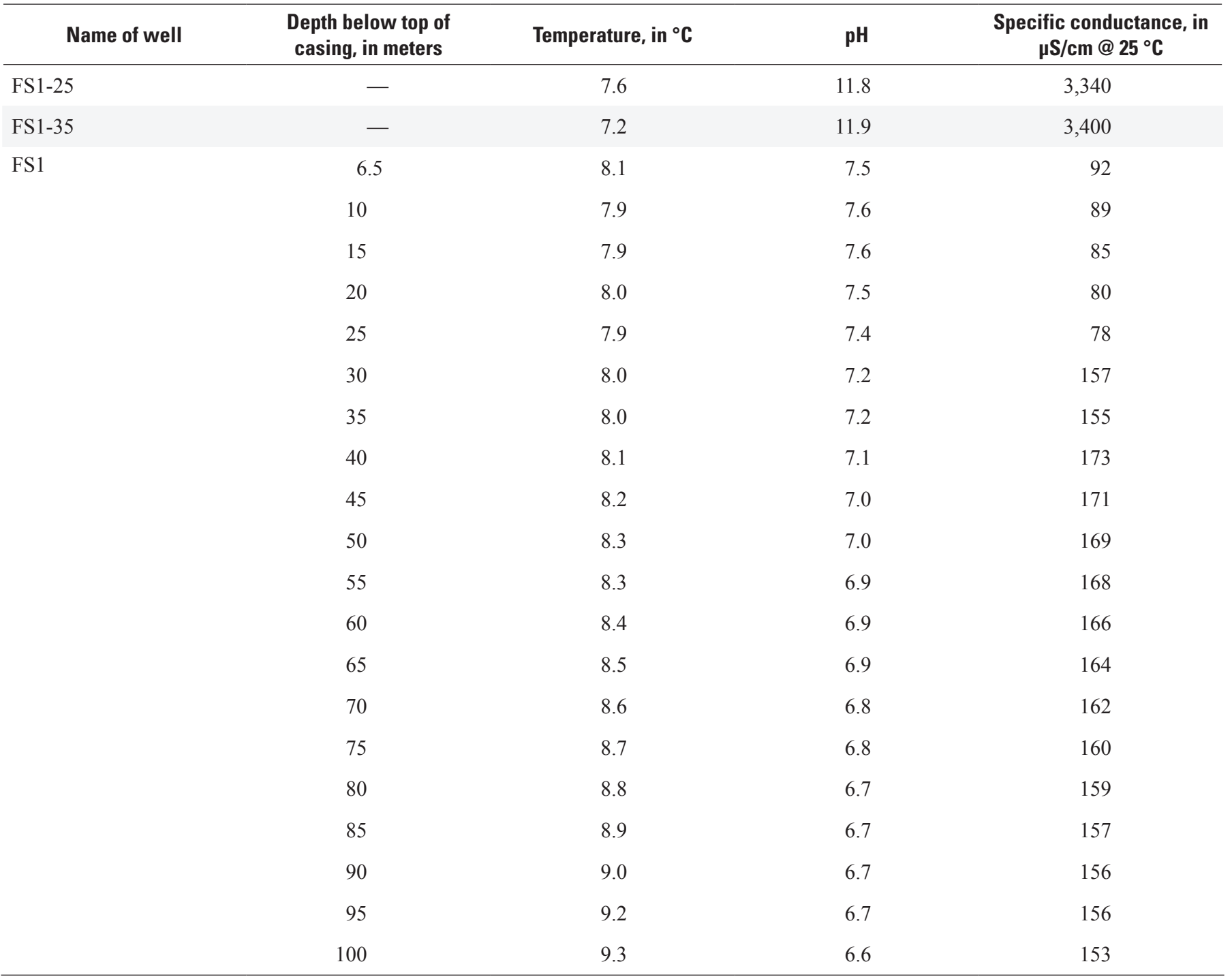


Table 19. Vertical variation of in situ temperature, $\mathrm{pH}$, and specific conductance of groundwater in the Mirror Lake watershed, New Hampshire, in bedrock well FS2 and adjacent piezometer FS2-25, July 20, 1988.

$\left[{ }^{\circ} \mathrm{C}\right.$, degrees Celsius; $\mu \mathrm{S} / \mathrm{cm} @ 25^{\circ} \mathrm{C}$, microsiemens per centimeter at 25 degrees Celsius; - , not applicable $]$

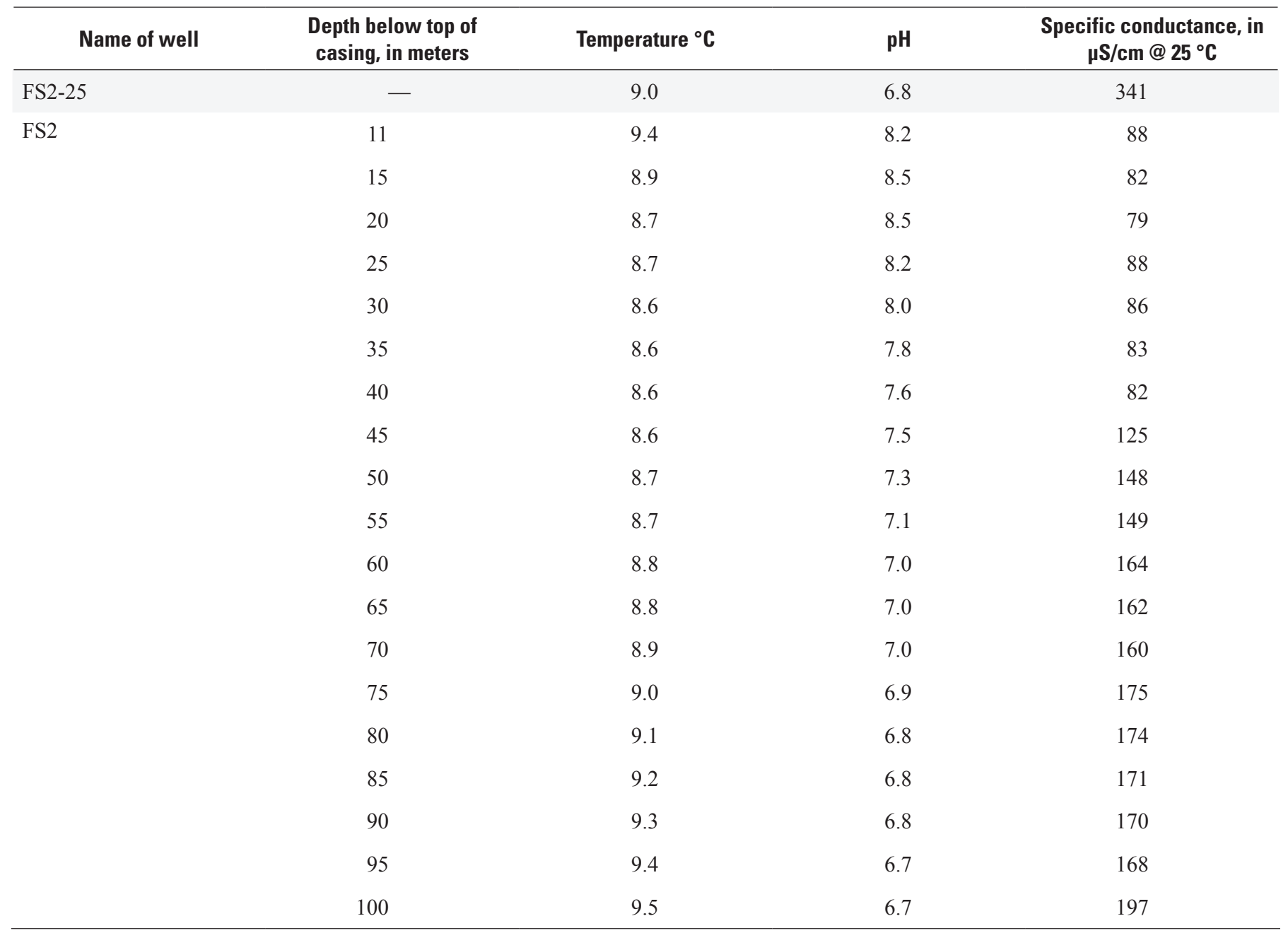


Table 20. Vertical variation of in situ temperature, $\mathrm{pH}$, and specific conductance of groundwater in the Mirror Lake watershed, New Hampshire, in bedrock well FSE2 and adjacent piezometers FSE-23, FSE-32, and FSE-43, July 20, 1988.

$\left[{ }^{\circ} \mathrm{C}\right.$, degrees Celsius; $\mu \mathrm{S} / \mathrm{cm} @ 25^{\circ} \mathrm{C}$, microsiemens per centimeter at 25 degrees Celsius; -, not applicable]

\begin{tabular}{|c|c|c|c|c|}
\hline Name of well & $\begin{array}{l}\text { Depth below top of } \\
\text { casing, in meters }\end{array}$ & Temperature ${ }^{\circ} \mathrm{C}$ & $\mathrm{pH}$ & $\begin{array}{c}\text { Specific conductance, in } \\
\mu \mathrm{S} / \mathrm{cm} @ 25^{\circ} \mathrm{C}\end{array}$ \\
\hline FSE-23 & - & 7.6 & 11.6 & 1,083 \\
\hline FSE-43 & - & 9.0 & 12.4 & 6,880 \\
\hline \multirow[t]{12}{*}{ FSE2 } & 8.5 & 9.0 & 6.4 & 451 \\
\hline & 15 & 8.7 & 6.6 & 444 \\
\hline & 20 & 8.9 & 6.6 & 415 \\
\hline & 25 & 8.8 & 6.6 & 405 \\
\hline & 45 & 9.1 & 6.3 & 387 \\
\hline & 50 & 9.2 & 6.3 & 571 \\
\hline & 55 & 9.3 & 6.3 & 646 \\
\hline & 60 & 9.3 & 6.3 & 645 \\
\hline & 65 & 9.3 & 6.2 & 643 \\
\hline & 70 & 9.4 & 6.2 & 641 \\
\hline & 75 & 9.5 & 6.3 & 638 \\
\hline & 100 & 10.0 & 6.2 & 628 \\
\hline
\end{tabular}


Table 21. Vertical variation of in situ temperature, $\mathrm{pH}$, and specific conductance of groundwater in the Mirror Lake watershed, New Hampshire, in bedrock well FSE3, July 20, 1988.

$\left[{ }^{\circ} \mathrm{C}\right.$, degrees Celsius; $\mu \mathrm{S} / \mathrm{cm} @ 25^{\circ} \mathrm{C}$, microsiemens per centimeter at 25 degrees Celsius $]$

\begin{tabular}{|c|c|c|c|c|}
\hline Name of well & $\begin{array}{l}\text { Depth below top of } \\
\text { casing, in meters }\end{array}$ & Temperature, in ${ }^{\circ} \mathrm{C}$ & pH & $\begin{array}{c}\text { Specific conductance, in } \\
\mu \mathrm{S} / \mathrm{cm} @ 25^{\circ} \mathrm{C}\end{array}$ \\
\hline \multirow[t]{13}{*}{ FSE3 } & 8 & 10.1 & 6.6 & 233 \\
\hline & 15 & 8.9 & 6.6 & 294 \\
\hline & 20 & 9.0 & 6.4 & 282 \\
\hline & 30 & 8.8 & 6.3 & 276 \\
\hline & 35 & 8.7 & 6.2 & 273 \\
\hline & 40 & 9.1 & 6.2 & 268 \\
\hline & 60 & 9.2 & 5.9 & 839 \\
\hline & 65 & 9.3 & 5.9 & 836 \\
\hline & 70 & 9.3 & 5.9 & 834 \\
\hline & 75 & 9.4 & 5.9 & 833 \\
\hline & 80 & 9.5 & 5.7 & 1,207 \\
\hline & 85 & 9.6 & 5.7 & 1,204 \\
\hline & 90 & 9.7 & 5.7 & 1,203 \\
\hline
\end{tabular}


Table 22. Vertical variation of in situ temperature, $\mathrm{pH}$, and specific conductance of groundwater in the Mirror Lake watershed, New Hampshire, in bedrock well FSE4, July 20, 1988.

$\left[{ }^{\circ} \mathrm{C}\right.$, degrees Celsius; $\mu \mathrm{S} / \mathrm{cm} @ 25{ }^{\circ} \mathrm{C}$, microsiemens per centimeter at 25 degrees Celsius $]$

\begin{tabular}{|c|c|c|c|c|}
\hline Name of well & $\begin{array}{l}\text { Depth below top of } \\
\text { casing, in meters }\end{array}$ & Temperature, in ${ }^{\circ} \mathrm{C}$ & $\mathrm{pH}$ & $\begin{array}{c}\text { Specific conductance, in } \\
\mu \mathrm{S} / \mathrm{cm} @ 25^{\circ} \mathrm{C}\end{array}$ \\
\hline \multirow[t]{20}{*}{ FSE4 } & 8.5 & 9.3 & 6.4 & 632 \\
\hline & 10 & 8.8 & 6.5 & 628 \\
\hline & 15 & 8.9 & 6.6 & 615 \\
\hline & 20 & 9.4 & 6.7 & 601 \\
\hline & 25 & 9.3 & 6.6 & 556 \\
\hline & 30 & 9.4 & 6.6 & 526 \\
\hline & 35 & 9.3 & 6.5 & 497 \\
\hline & 40 & 9.3 & 6.4 & 472 \\
\hline & 45 & 9.3 & 6.3 & 942 \\
\hline & 50 & 9.3 & 5.8 & 1,001 \\
\hline & 55 & 9.4 & 5.8 & 999 \\
\hline & 60 & 9.4 & 5.8 & 996 \\
\hline & 65 & 9.6 & 5.8 & 993 \\
\hline & 70 & 9.7 & 5.7 & 991 \\
\hline & 75 & 9.7 & 5.7 & 988 \\
\hline & 80 & 9.8 & 5.7 & 986 \\
\hline & 85 & 9.9 & 5.7 & 984 \\
\hline & 90 & 10.0 & 5.7 & 982 \\
\hline & 95 & 10.0 & 5.7 & 979 \\
\hline & 100 & 10.1 & 5.7 & 977 \\
\hline
\end{tabular}


Table 23. Vertical variation of in situ temperature, $\mathrm{pH}$, and specific conductance of groundwater in the Mirror Lake watershed, New Hampshire, in bedrock well TR1 and adjacent water-table well TR1-63 and piezometer TR1-132, July 19, 1988.

$\left[{ }^{\circ} \mathrm{C}\right.$, degrees Celsius; $\mu \mathrm{S} / \mathrm{cm} @ 25^{\circ} \mathrm{C}$, microsiemens per centimeter at 25 degrees Celsius; —, not applicable]

\begin{tabular}{|c|c|c|c|c|}
\hline Name of well & $\begin{array}{l}\text { Depth below top of } \\
\text { casing, in meters }\end{array}$ & Temperature, in ${ }^{\circ} \mathrm{C}$ & $\mathrm{pH}$ & $\begin{array}{c}\text { Specific conductance, in } \\
\mu \mathrm{S} / \mathrm{cm} @ 25^{\circ} \mathrm{C}\end{array}$ \\
\hline TR1- 63 & - & 8.3 & 8.6 & 46 \\
\hline \multirow[t]{8}{*}{ TR1 } & 15 (in air?) & 11.7 & 7.0 & $\wedge$ \\
\hline & 20 & 8.8 & 8.4 & 86 \\
\hline & 30 & 8.9 & 9.3 & 78 \\
\hline & 35 & 9.0 & 9.4 & 75 \\
\hline & 40 & 8.5 & 9.5 & 75 \\
\hline & 60 & 8.7 & 8.6 & 124 \\
\hline & 65 & 8.8 & 8.5 & 121 \\
\hline & 70 & 8.8 & 8.4 & 120 \\
\hline
\end{tabular}

\footnotetext{
${ }^{1 \wedge}$, indicates value out of range - specific conductance sensor of probe likely not fully immersed.
} 
Table 24. Vertical variation of in situ temperature, $\mathrm{pH}$, and specific conductance of groundwater in the Mirror Lake watershed, New Hampshire, in bedrock well K2 and adjacent piezometers K2-21, K2-31, and K2-41, July 19, 1988.

$\left[{ }^{\circ} \mathrm{C}\right.$, degrees Celsius; $\mu \mathrm{S} / \mathrm{cm} @ 25^{\circ} \mathrm{C}$, microsiemens per centimeter at 25 degrees Celsius; —, not applicable]

\begin{tabular}{|c|c|c|c|c|}
\hline Name of well & $\begin{array}{l}\text { Depth below top of } \\
\text { casing, in meters }\end{array}$ & Temperature, in ${ }^{\circ} \mathrm{C}$ & $\mathrm{pH}$ & $\begin{array}{c}\text { Specific conductance, in } \\
\mu \mathrm{S} / \mathrm{cm} @ 25^{\circ} \mathrm{C}\end{array}$ \\
\hline K2-21 & - & 8.1 & 7.0 & 212 \\
\hline K2-41 & - & 8.9 & 7.5 & 158 \\
\hline \multirow[t]{7}{*}{$\mathrm{K} 2$} & 4 (in air?) & 14.0 & 6.6 & $\wedge 1$ \\
\hline & 10 & 8.1 & 7.8 & 204 \\
\hline & 15 & 10.2 & 7.8 & 198 \\
\hline & 20 & 10.5 & 7.9 & 194 \\
\hline & 40 & 10.1 & 8.0 & 191 \\
\hline & 45 & 10.0 & 8.0 & 188 \\
\hline & 50 & 10.0 & 8.0 & 208 \\
\hline
\end{tabular}

\footnotetext{
${ }^{1 \wedge}$. indicates value out of range - specific conductance sensor of probe likely not fully immersed.
} 
Table 25. Vertical variation of in situ temperature, $\mathrm{pH}$, and specific conductance of groundwater in the Mirror Lake watershed, New Hampshire, in bedrock well CO1 and adjacent water-table well CO WT, July 19, 1988.

$\left[{ }^{\circ} \mathrm{C}\right.$, degrees Celsius; $\mu \mathrm{S} / \mathrm{cm} @ 25^{\circ} \mathrm{C}$, microsiemens per centimeter at 25 degrees Celsius; 一, not applicable]

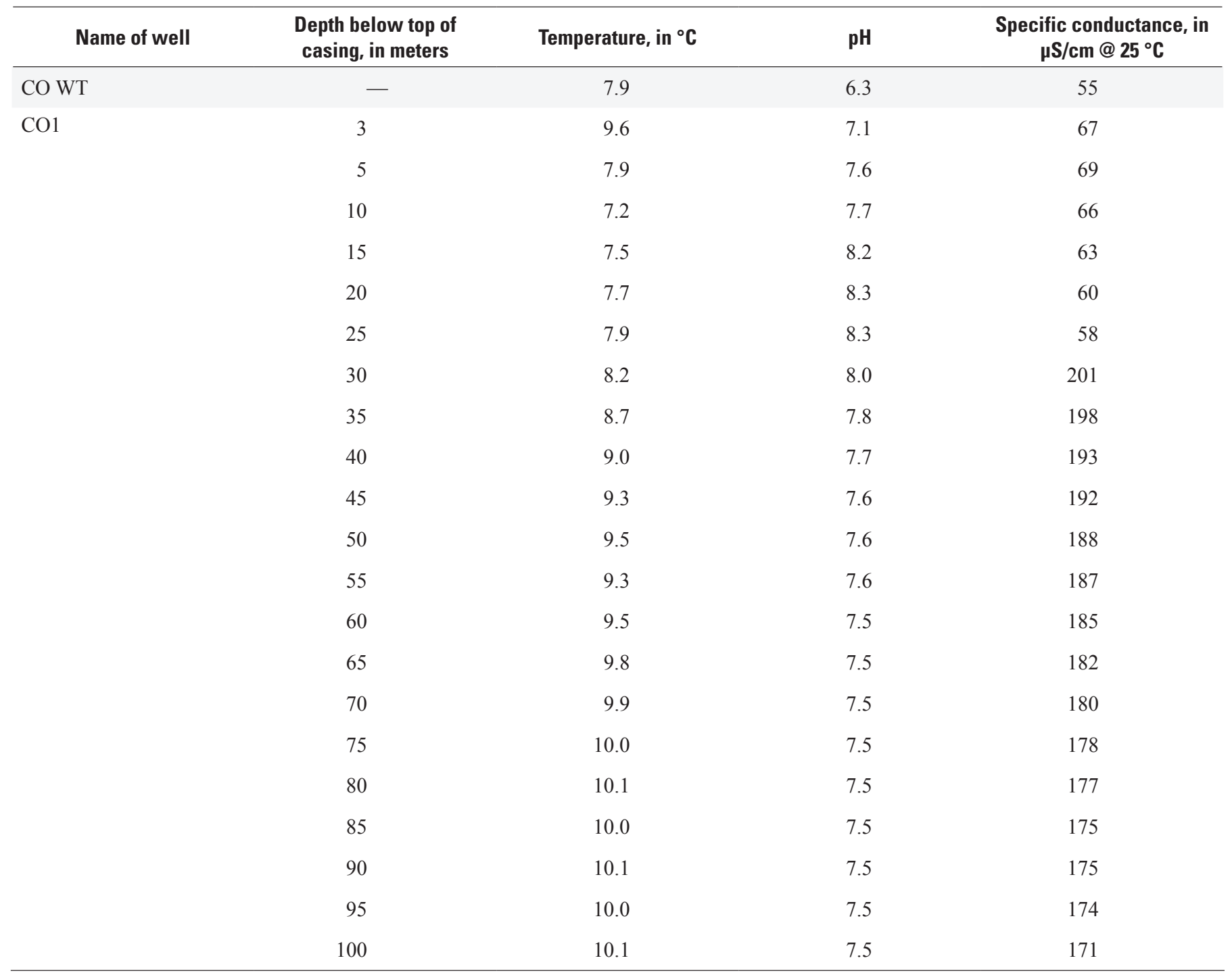




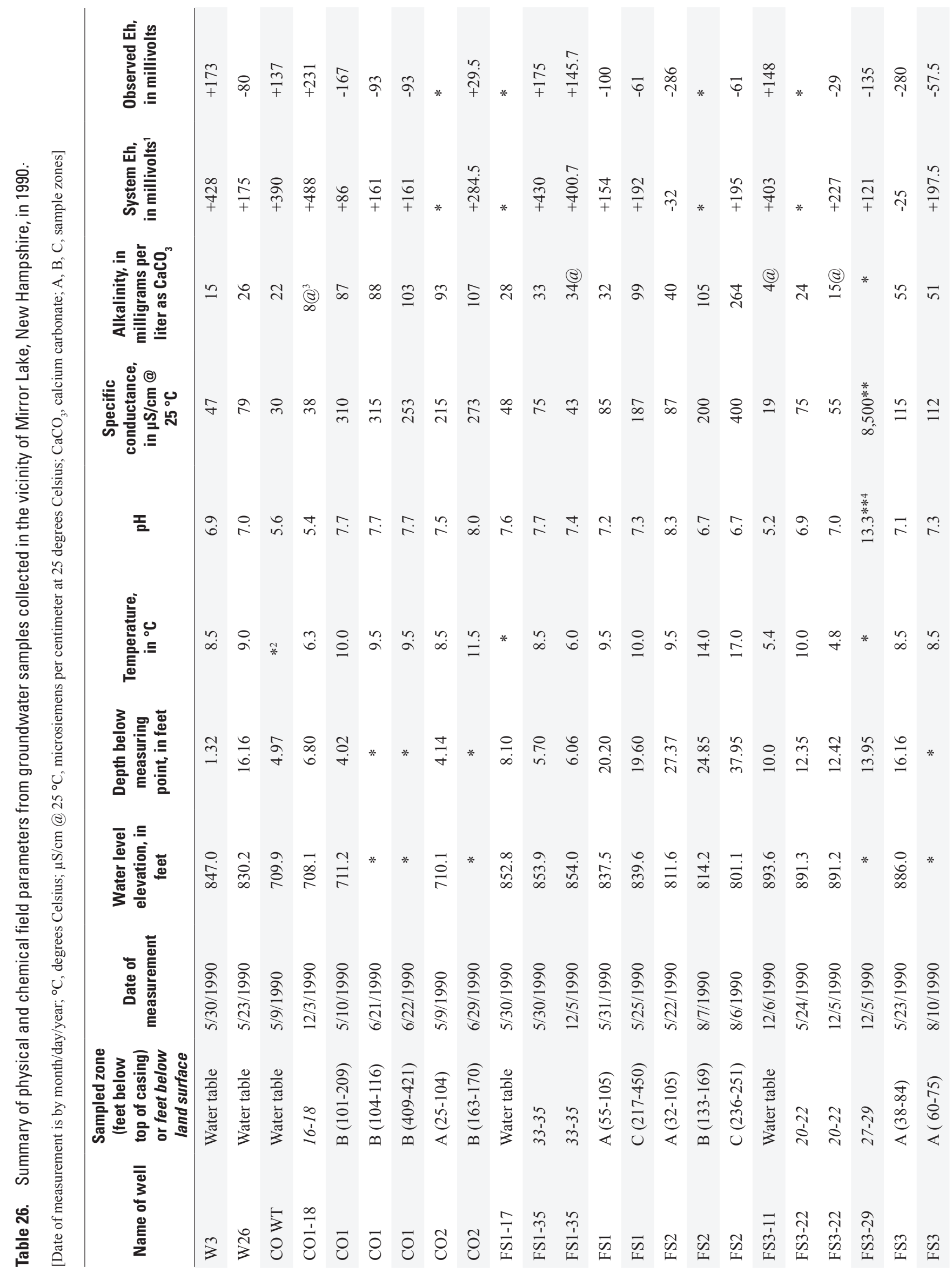




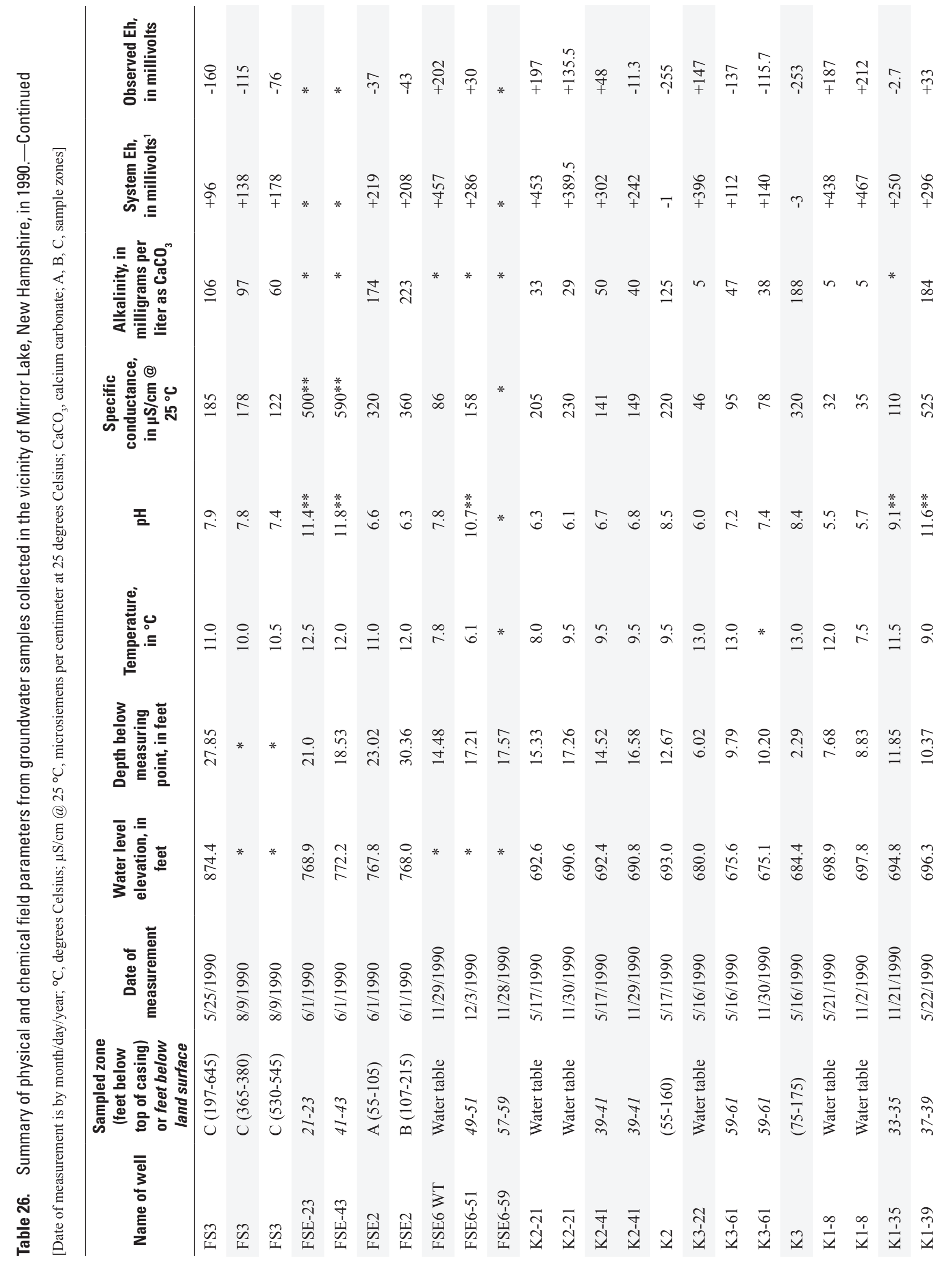




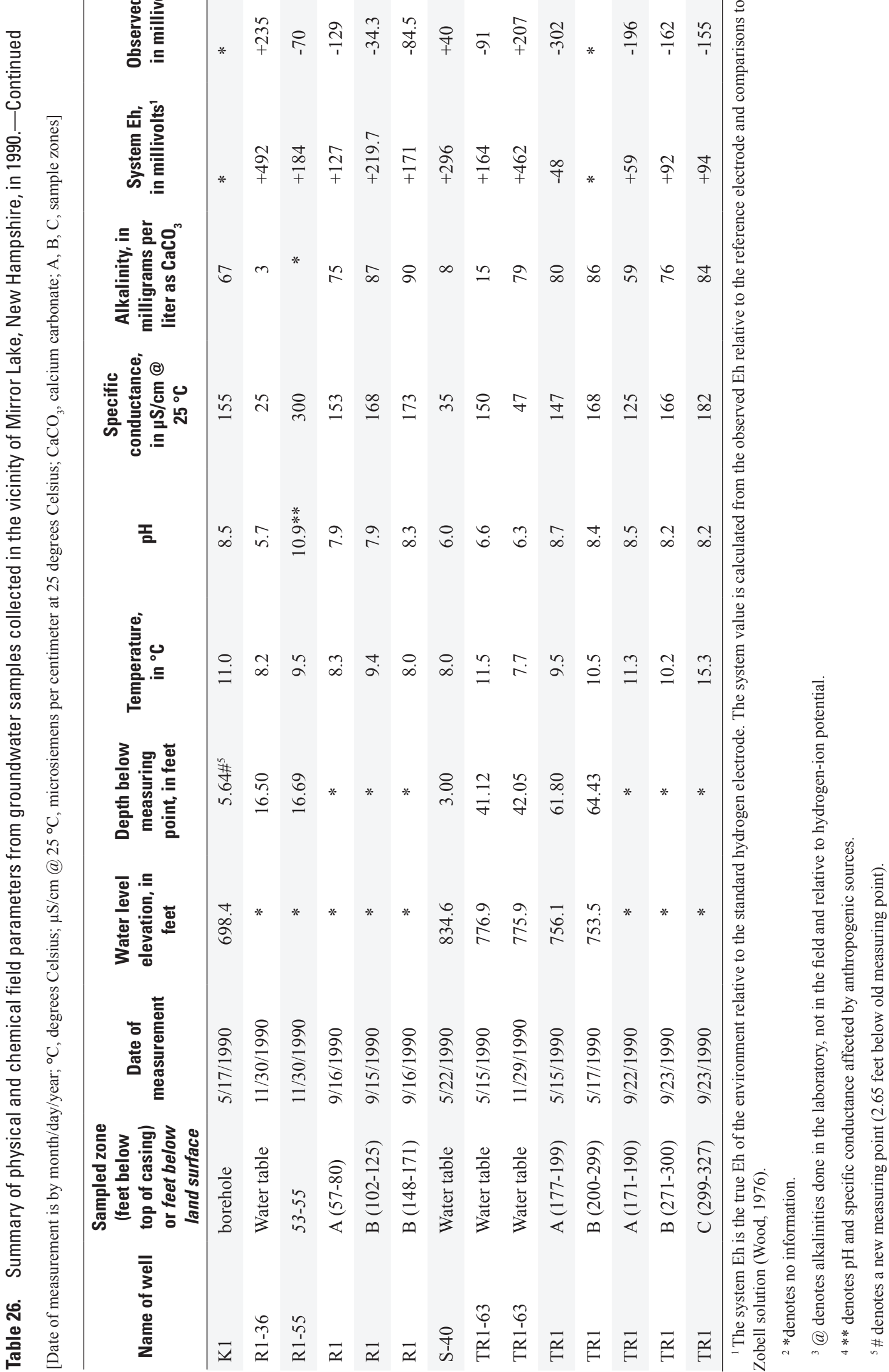


Table 27. Physical and chemical characteristics of water collected from selected wells, a seep and a spring in the vicinity of Mirror Lake, New Hampshire, 1993, 1995, 1996, and 1997.

[Water was measured at the end of the copper tubing discharging water from the well at the time of sample collection; date of measurement is by month/day/ year; ${ }^{\circ} \mathrm{C}$, degrees Celsius; $\mu \mathrm{S} / \mathrm{cm} @ 25^{\circ} \mathrm{C}$, microsiemens per centimeter at 25 degrees Celsius; HCO3-, bicarbonate; >, greater than]

\begin{tabular}{|c|c|c|c|c|c|c|c|}
\hline $\begin{array}{l}\text { Name of well, } \\
\text { seep, or spring }\end{array}$ & $\begin{array}{c}\text { Sampled } \\
\text { zones (feet } \\
\text { below top of } \\
\text { casing) or feet } \\
\text { below land } \\
\text { surface }\end{array}$ & $\begin{array}{c}\text { Date of } \\
\text { measurement }\end{array}$ & $\begin{array}{c}\text { Temperature, }{ }^{1} \\
\text { in }{ }^{\circ} \mathrm{C}\end{array}$ & $\mathrm{pH}$ & $\begin{array}{c}\text { Specific } \\
\text { conductance, } \\
\text { in } \mu \mathrm{S} / \mathrm{cm} @ \\
25^{\circ} \mathrm{C}\end{array}$ & $\begin{array}{c}\text { Dissolved } \\
\text { oxygen, in } \\
\text { milligrams per } \\
\text { liter }\end{array}$ & $\begin{array}{l}\text { Alkalinity, in } \\
\text { milligrams per } \\
\text { liter as } \mathrm{HCO}_{3}^{-}\end{array}$ \\
\hline W2 & Water table & $6 / 20 / 1995$ & 17 & 6.4 & 74 & 0.0 & 25.9 \\
\hline W2 & Water table & 6/7/1997 & $9-12$ & 7.0 & 75 & $0.5-1.0$ & $*$ \\
\hline W3 & Water table & $6 / 23 / 1995$ & 16 & 6.3 & 47 & 3.0 & 14.2 \\
\hline W3 & Water table & 7/14/1997 & $11-20$ & 6.0 & 52 & 2.5 & $*$ \\
\hline W3A & Water table & $6 / 23 / 1995$ & 19 & 5.4 & 23 & 6.8 & 6.83 \\
\hline W11 & Water table & 7/25/1997 & $10-13$ & 5.5 & 38 & 6.9 & $*$ \\
\hline W15 & Water table & $7 / 28 / 1997$ & $17-20$ & 6.2 & $50-70$ & 1.9 & $*$ \\
\hline W16 & Water table & $8 / 28 / 1996$ & 13 & 7.0 & $120-180$ & 0.1 & $*$ \\
\hline W16 & Water table & 7/13/1997 & $10-20$ & $6.0-6.8$ & $140-170$ & 0.5 & $*$ \\
\hline W16A & Water table & $8 / 27 / 1996$ & 15 & 7.0 & 80 & 3.0 & $*$ \\
\hline W16A & Water table & 7/8/1997 & 12 & 6.0 & $62-86$ & $*$ & $*$ \\
\hline W16A & Water table & 7/12/1997 & 13 & 6.3 & $50-72$ & $*$ & $*$ \\
\hline W26 & Water table & $8 / 26 / 1996$ & $\mathrm{nr}$ & 6.4 & 80 & 0.05 & $*$ \\
\hline W26 & Water table & 6/8/1997 & $10-12$ & 6.7 & 85 & $0.5-0.7$ & $*$ \\
\hline W27 & Water table & $7 / 16 / 1995$ & 20 & 6.3 & 54 & 5.1 & 22.0 \\
\hline W27 & Water table & $6 / 19 / 1997$ & 10 & 5.8 & 50 & 4 & $*$ \\
\hline W33 & Water table & $8 / 22 / 1996$ & 24 & 6.8 & 74 & 0.04 & $*$ \\
\hline W33 & Water table & 7/7/1997 & 10 & 64 & 78 & 0 & $*$ \\
\hline W34 & Water table & $8 / 22 / 1996$ & $\mathrm{nr}$ & 7.0 & 55 & 2.7 & $*$ \\
\hline W34 & Water table & 6/10/1997 & $9-14$ & 6.3 & 37 & $6-7$ & $*$ \\
\hline W35 & Water table & $8 / 27 / 1996$ & 15 & $*$ & 60 & 0.2 & $*$ \\
\hline W35 & Water table & 7/11/1997 & 9.3 & $5.0-5.8$ & 35 & 4.6 & $*$ \\
\hline
\end{tabular}


Table 27. Physical and chemical characteristics of water collected from selected wells, a seep and a spring in the vicinity of Mirror Lake, New Hampshire, 1993, 1995, 1996, and 1997.-Continued

[Water was measured at the end of the copper tubing discharging water from the well at the time of sample collection; date of measurement is by month/day/ year; ${ }^{\circ} \mathrm{C}$, degrees Celsius; $\mu \mathrm{S} / \mathrm{cm} @ 25^{\circ} \mathrm{C}$, microsiemens per centimeter at 25 degrees Celsius; HCO3-, bicarbonate; >, greater than]

\begin{tabular}{|c|c|c|c|c|c|c|c|}
\hline $\begin{array}{l}\text { Name of well, } \\
\text { seep, or spring }\end{array}$ & $\begin{array}{c}\text { Sampled } \\
\text { zones (feet } \\
\text { below top of } \\
\text { casing) or feet } \\
\text { below land } \\
\text { surface }\end{array}$ & $\begin{array}{c}\text { Date of } \\
\text { measurement }\end{array}$ & $\begin{array}{c}\text { Temperature, }{ }^{1} \\
\text { in }{ }^{\circ} \mathrm{C}\end{array}$ & $\mathrm{pH}$ & $\begin{array}{c}\text { Specific } \\
\text { conductance, } \\
\text { in } \mu S / \mathrm{cm} @ \\
25^{\circ} \mathrm{C}\end{array}$ & $\begin{array}{c}\text { Dissolved } \\
\text { oxygen, in } \\
\text { milligrams per } \\
\text { liter }\end{array}$ & $\begin{array}{l}\text { Alkalinity, in } \\
\text { milligrams per } \\
\text { liter as } \mathrm{HCO}_{3}^{-}\end{array}$ \\
\hline W36 & Water table & 8/26/1996 & 15 & 6.0 & 39 & 3.0 & $*$ \\
\hline W36 & Water table & $6 / 17 / 1997$ & 8.0 & 5.4 & 23 & 7.8 & $*$ \\
\hline $\mathrm{CO} 10$ & $(130.0-143.5)$ & $8 / 15 / 1995$ & 14.3 & 7.30 & 965 & 0.005 & 136.7 \\
\hline $\mathrm{CO} 10$ & $(228.0-241.5)$ & $8 / 15 / 1995$ & 10 & 8.01 & 400 & 0.5 & 119.1 \\
\hline CO11 & $(95.0-108.5)$ & $8 / 16 / 1995$ & 10.5 & 7.32 & 681 & 0.04 & 120.8 \\
\hline FS1-17 & Water table & 7/18/1995 & 15 & 6.6 & 77 & 0.01 & 40.8 \\
\hline FS1-17 & Water table & 7/19/1996 & $\mathrm{nr}$ & 6.8 & 74 & $0.1-0.7$ & $*$ \\
\hline FS1-25 & $23-25$ & $7 / 20 / 1996$ & $\mathrm{nr}$ & 11.0 & 370 & 3.0 & $*$ \\
\hline FS1-35 & $33-35$ & $7 / 20 / 1996$ & $\mathrm{nr}$ & 5.3 & 24 & 4.0 & $*$ \\
\hline FS3 & $60.0-72.4$ & 7/19/1993 & 9.8 & 7.5 & 122 & 0.5 & 63.2 \\
\hline FS3 & $294.0-306.2$ & $7 / 20 / 1993$ & 10.5 & 7.95 & 172 & 1.75 & 112.3 \\
\hline FS3 & $365.0-377.2$ & $7 / 20 / 1993$ & 10.2 & 7.87 & 184 & 0.75 & 122.0 \\
\hline FS3C-29 & $28-29$ & 7/17/1996 & $\mathrm{nr}$ & 6.5 & 29 & 6.2 & 6 \\
\hline FS3C-29 & $28-29$ & 6/11/1997 & $7-12$ & 5.0 & 22 & 5.8 & $*$ \\
\hline FS4 WT & Water table & 7/8/1997 & 10.6 & $4.0-5.0$ & $54-76$ & 4.7 & $*$ \\
\hline FS5 & $(70.0-83.5)$ & 6/9/1995 & 13.3 & 8.30 & 152 & $>0.1$ & $*$ \\
\hline FS5 & $(142.0-155.5)$ & 6/9/1995 & 10.5 & 8.16 & 135 & 0.12 & 85.7 \\
\hline FS5 & $(200.4-218.0)$ & $6 / 8 / 1995$ & 9 & 8.06 & 138 & 0.18 & 86.9 \\
\hline FS6 & $44.0-53.5$ & $8 / 12 / 1995$ & 9.8 & 6.48 & 320 & 0.0 & 166.0 \\
\hline $\mathrm{R} 1-36$ & Water table & $7 / 10 / 1995$ & 8 & 6.4 & 23 & 10.6 & 2.93 \\
\hline $\mathrm{R} 1-55$ & $53-55$ & $7 / 11 / 1995$ & 18 & 10.2 & 190 & 0.0 & $*$ \\
\hline RR1 PZ & Water table & $8 / 21 / 1995$ & 13.5 & 6.6 & 575 & 0.8 & 53.7 \\
\hline
\end{tabular}


Table 27. Physical and chemical characteristics of water collected from selected wells, a seep and a spring in the vicinity of Mirror Lake, New Hampshire, 1993, 1995, 1996, and 1997.-Continued

[Water was measured at the end of the copper tubing discharging water from the well at the time of sample collection; date of measurement is by month/day/ year; ${ }^{\circ} \mathrm{C}$, degrees Celsius; $\mu \mathrm{S} / \mathrm{cm} @ 25^{\circ} \mathrm{C}$, microsiemens per centimeter at 25 degrees Celsius; HCO3-, bicarbonate; >, greater than]

\begin{tabular}{|c|c|c|c|c|c|c|c|}
\hline $\begin{array}{l}\text { Name of well, } \\
\text { seep, or spring }\end{array}$ & $\begin{array}{c}\text { Sampled } \\
\text { zones (feet } \\
\text { below top of } \\
\text { casing) or feet } \\
\text { below land } \\
\text { surface }\end{array}$ & $\begin{array}{c}\text { Date of } \\
\text { measurement }\end{array}$ & $\begin{array}{c}\text { Temperature, } \\
\text { in }{ }^{\circ} \mathrm{C}\end{array}$ & $\mathrm{pH}$ & $\begin{array}{c}\text { Specific } \\
\text { conductance, } \\
\text { in } \mu \mathrm{S} / \mathrm{cm} @ \\
25^{\circ} \mathrm{C}\end{array}$ & $\begin{array}{c}\text { Dissolved } \\
\text { oxygen, in } \\
\text { milligrams per } \\
\text { liter }\end{array}$ & $\begin{array}{l}\text { Alkalinity, in } \\
\text { milligrams per } \\
\text { liter as } \mathrm{HCO}_{3}^{-}\end{array}$ \\
\hline RR1 & $(582.5-596.0)$ & $8 / 18 / 1995$ & 12.3 & 6.36 & 2,660 & 0.0 & $*$ \\
\hline TR1-63 & Water table & $6 / 25 / 1997$ & $9.0-16.0$ & 6.1 & 46 & 9.2 & $*$ \\
\hline TR2 & $(151.0-170.3)$ & $7 / 21 / 1993$ & 11.2 & 8.15 & 243 & 0.5 & 142.8 \\
\hline TR2 & $(270.0-289.3)$ & $7 / 21 / 1993$ & 10.9 & 7.88 & 323 & 0.45 & 38.5 \\
\hline TR2 & $(426.0-445.3)$ & $7 / 22 / 1993$ & 10.6 & 7.97 & 401 & 1.2 & 252.6 \\
\hline
\end{tabular}

${ }^{1}$ Over long pumping periods and at low flow rates, the temperature of water at the end of the copper tubing varies with air temperature; nr indicates temperature not recorded.

$2 *$ No information. 
Table 28. Radon survey of water collected from selected wells in the vicinity of Mirror Lake, New Hampshire, 1992 and 1993.

[Date of collection is by month/day/year]

\begin{tabular}{|c|c|c|c|c|c|}
\hline Name of well & $\begin{array}{c}\text { Sampled zones, in } \\
\text { feet below reference }\end{array}$ & Reference & Date of collection & Time of day & $\begin{array}{c}\text { Radon } 222^{1} \\
\text { Disintigrations per } \\
\text { minute } \\
+/-\end{array}$ \\
\hline $\mathrm{CO} 1$ & $104-114$ & Land surface & $6 / 16 / 1992$ & $12: 15$ & $3,343+/-30$ \\
\hline $\mathrm{CO} 1$ & $104-114$ & Land surface & $6 / 16 / 1992$ & $13: 05$ & $4,200+/-107$ \\
\hline $\mathrm{CO} 4$ & $92-98.8$ & Top of casing & $6 / 11 / 1992$ & $12: 53$ & $2,251+/-87$ \\
\hline $\mathrm{CO} 4$ & $92-98.8$ & Top of casing & $6 / 11 / 1992$ & $13: 31$ & $2,172+/-16$ \\
\hline IS1 & $56-58.8$ & Top of casing & $6 / 3 / 1992$ & $11: 02$ & $9,017+/-93$ \\
\hline IS1 & $56-58.8$ & Top of casing & 6/3/1992 & $12: 30$ & $11,601+/-111$ \\
\hline IS1 & $400-405.8$ & Top of casing & 6/4/1992 & $14: 55$ & $9,425+/-112$ \\
\hline IS1 & $466.5-473.3$ & Top of casing & 6/4/1992 & $17: 04$ & $706+/-16$ \\
\hline FS2 & $134-149.3$ & Land surface & 7/7/1992 & $19: 25$ & $1,203+/-8$ \\
\hline $\mathrm{FS} 2$ & $134-149.3$ & Land surface & 7/7/1992 & $19: 53$ & $1,103+/-6$ \\
\hline FS2 & $134-149.3$ & Land surface & 7/7/1992 & $20: 39$ & $1,232+/-4$ \\
\hline FS2 & $236-251.3$ & Land surface & 7/8/1992 & $12: 36$ & $1,298+/-55$ \\
\hline FS2 & $236-251.3$ & Land surface & 7/8/1992 & $13: 43$ & $1,519+/-46$ \\
\hline $\mathrm{FS} 2$ & $236-251.3$ & Land surface & 7/8/1992 & $14: 10$ & $1,313+/-46$ \\
\hline $\mathrm{FS} 2$ & $384-399.3$ & Land surface & 7/8/1992 & $17: 29$ & $1,904+/-8$ \\
\hline FS3 & $60-75.1$ & Land surface & 7/12/1992 & $13: 53$ & $2,900+/-19$ \\
\hline FS3 & $60-75.1$ & Land surface & $7 / 12 / 1992$ & $14: 30$ & $3,173+/-51$ \\
\hline FS3 & $60-75.1$ & Land surface & $7 / 12 / 1992$ & $14: 48$ & $3,436+/-61$ \\
\hline FS3 & $60-72.4$ & Land surface & 7/19/1993 & $15: 03$ & 3,415 \\
\hline FS3 & $60-72.4$ & Land surface & 7/19/1993 & $15: 18$ & 1,470 \\
\hline FS3 & $60-72.4$ & Land surface & 7/19/1993 & $15: 25$ & 3,963 \\
\hline FS3 & 294-309.1 & Land surface & 7/11/1992 & $13: 36$ & $2,007+/-16$ \\
\hline FS3 & 294-309.1 & Land surface & 7/11/1992 & $14: 39$ & $2,552+/-32$ \\
\hline FS3 & 294-309.1 & Land surface & 7/11/1992 & $15: 12$ & $3,252+/-16$ \\
\hline FS3 & 294-309.1 & Land surface & 7/12/1992 & $17: 32$ & $2,542+/-114$ \\
\hline FS3 & 294-309.1 & Land surface & $7 / 12 / 1992$ & $18: 16$ & $3,347+/-50$ \\
\hline FS3 & 294-309.1 & Land surface & $7 / 12 / 1992$ & $19: 06$ & $3,572+/-31$ \\
\hline FS3 & 294-302.6 & Land surface & 7/20/1993 & $11: 06$ & 132 \\
\hline FS3 & $294-302.6$ & Land surface & $7 / 20 / 1993$ & $11: 58$ & 2,272 \\
\hline
\end{tabular}


Table 28. Radon survey of water collected from selected wells in the vicinity of Mirror Lake, New Hampshire, 1992 and 1993.-Continued

[Date of collection is by month/day/year]

\begin{tabular}{|c|c|c|c|c|c|}
\hline Name of well & $\begin{array}{c}\text { Sampled zones, in } \\
\text { feet below reference }\end{array}$ & Reference & Date of collection & Time of day & $\begin{array}{c}\text { Radon } 222^{1} \\
\text { Disintigrations per } \\
\text { minute } \\
+/-\end{array}$ \\
\hline FS3 & 294-302.6 & Land surface & 7/20/1993 & $12: 27$ & 2,642 \\
\hline FS3 & $365-380.1$ & Land surface & 7/13/1992 & $10: 20$ & $440+/-8$ \\
\hline FS3 & $365-372.2$ & Land surface & $7 / 20 / 1993$ & $15: 18$ & 262 \\
\hline FS3 & $365-372.2$ & Land surface & $7 / 20 / 1993$ & $15: 33$ & 292 \\
\hline FS3 & $365-372.2$ & Land surface & $7 / 20 / 1993$ & $16: 22$ & 277 \\
\hline FS3 & $530-545.1$ & Land surface & $7 / 13 / 1992$ & $13: 35$ & $2,205+/-35$ \\
\hline FSE4 & $438-445$ & Top of casing & $5 / 18 / 1992$ & $18: 10$ & $690+/-45$ \\
\hline FSE4 & $438-445$ & Top of casing & $5 / 18 / 1992$ & $18: 37$ & $1,102+/-31$ \\
\hline FSE6 WT & $10.5-15.5$ & Land surface & $5 / 20 / 1992$ & 09:39 & $1,179+/-53$ \\
\hline FSE6-32 & $30-32$ & Land surface & $5 / 21 / 1992$ & $10: 58$ & $2,895+/-43$ \\
\hline FSE6-32 & $30-32$ & Land surface & $5 / 21 / 1992$ & $12: 24$ & $2,860+/-54$ \\
\hline FSE6-51 & $49-51$ & Land surface & $5 / 20 / 1992$ & $15: 10$ & $910+/-10$ \\
\hline FSE6-59 & $57-59$ & Land surface & $5 / 20 / 1992$ & $20: 11$ & $440+/-22$ \\
\hline FSE-23 & $21-23$ & Land surface & $5 / 19 / 1992$ & $16: 18$ & $1,068+/-46$ \\
\hline FSE-32 & $30-32$ & Land surface & $5 / 19 / 1992$ & $13: 52$ & $730+/-4$ \\
\hline $\mathrm{R} 1$ & $65-80.1$ & Land surface & $7 / 14 / 1992$ & $13: 14$ & $1,279+/-54$ \\
\hline $\mathrm{R} 1$ & $65-80.1$ & Land surface & $7 / 14 / 1992$ & $14: 03$ & $2,246+/-16$ \\
\hline $\mathrm{R} 1$ & $65-80.1$ & Land surface & $7 / 14 / 1992$ & $14: 10$ & $1943+/-8$ \\
\hline $\mathrm{R} 1$ & $110-125.1$ & Land surface & $7 / 14 / 1992$ & $15: 58$ & $556+/-13$ \\
\hline $\mathrm{R} 1$ & $110-125.1$ & Land surface & $7 / 14 / 1992$ & $16: 26$ & $792+/-21$ \\
\hline $\mathrm{R} 1$ & $110-125.1$ & Land surface & $7 / 14 / 1992$ & $16: 43$ & $734+/-45$ \\
\hline $\mathrm{R} 1$ & $147-162.1$ & Land surface & $7 / 15 / 1992$ & $11: 49$ & $619+/-27$ \\
\hline $\mathrm{R} 1$ & $147-162.1$ & Land surface & $7 / 15 / 1992$ & $12: 27$ & $1,189+/-48$ \\
\hline $\mathrm{R} 1$ & $147-162.1$ & Land surface & $7 / 15 / 1992$ & $12: 48$ & $142+/-18$ \\
\hline $\mathrm{R} 1$ & $480-495.1$ & Land surface & $7 / 15 / 1992$ & $15: 54$ & $332+/-11$ \\
\hline $\mathrm{R} 1$ & $480-495.1$ & Land surface & 7/15/1992 & $17: 26$ & $352+/-24$ \\
\hline TR1 & $170-190$ & Land surface & $6 / 29 / 1992$ & $13: 24$ & $5,899+/-195$ \\
\hline TR1 & $170-190$ & Land surface & 6/29/1992 & $14: 00$ & $8,493+/-147$ \\
\hline TR1 & $170-190$ & Land surface & 6/29/1992 & $15: 01$ & $6,969+/-147$ \\
\hline
\end{tabular}


Table 28. Radon survey of water collected from selected wells in the vicinity of Mirror Lake, New Hampshire, 1992 and 1993.-Continued

[Date of collection is by month/day/year]

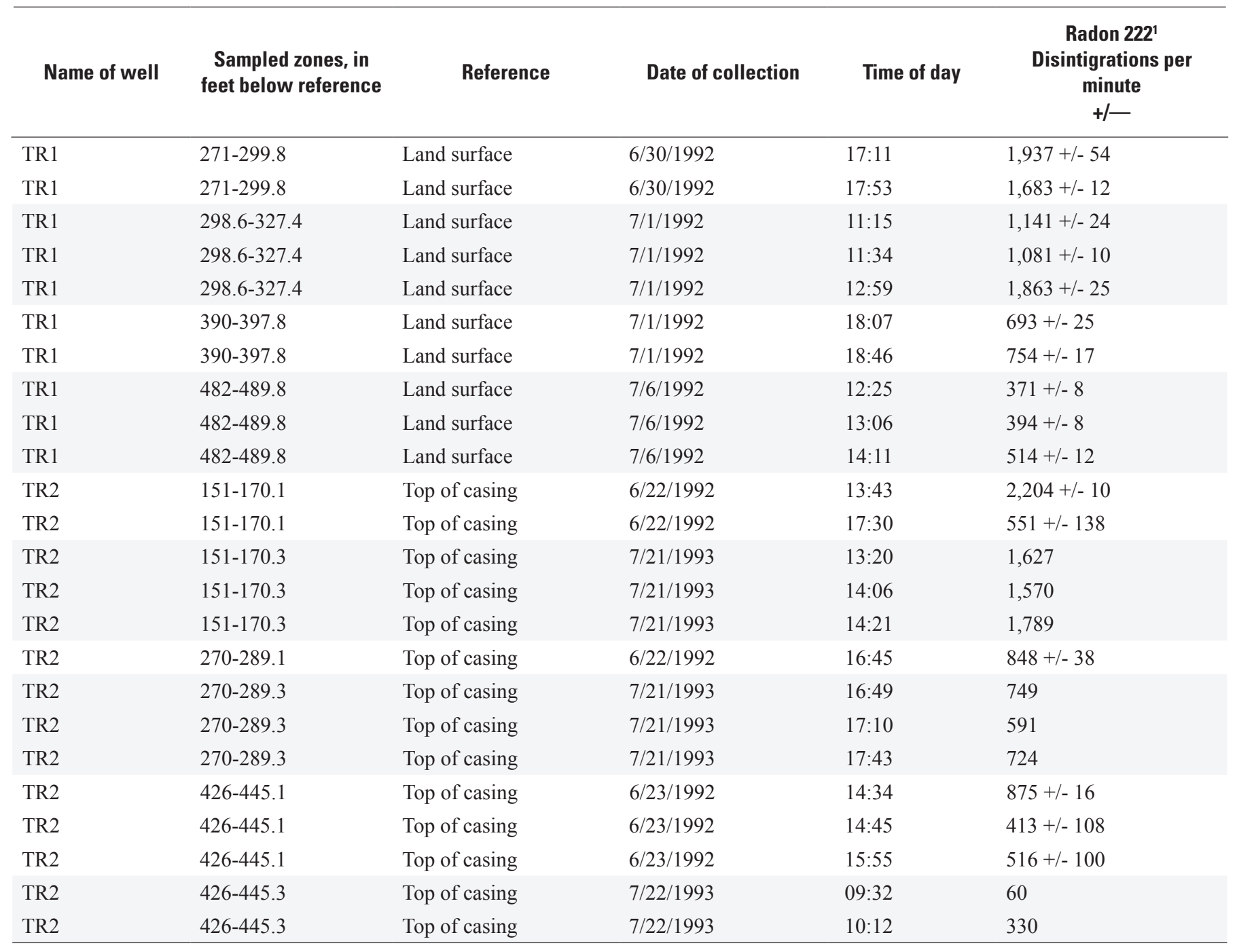

${ }^{1}$ Radon activities were determined in the field using Lucas cells and a portable scintillation counter. The reported radon value resulted from multiple determinations per cell beginning at the time noted. 


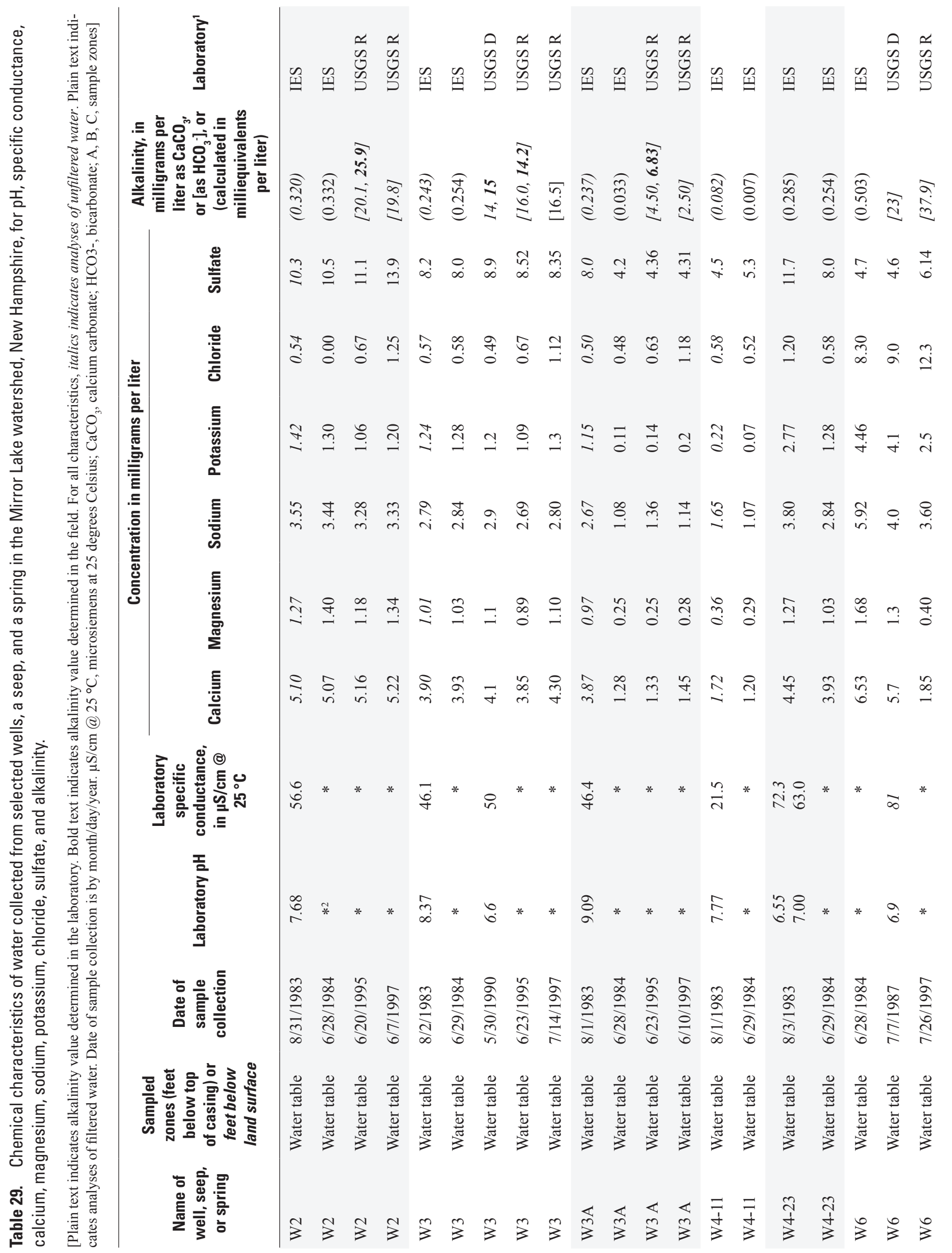


Tables $\quad 61$

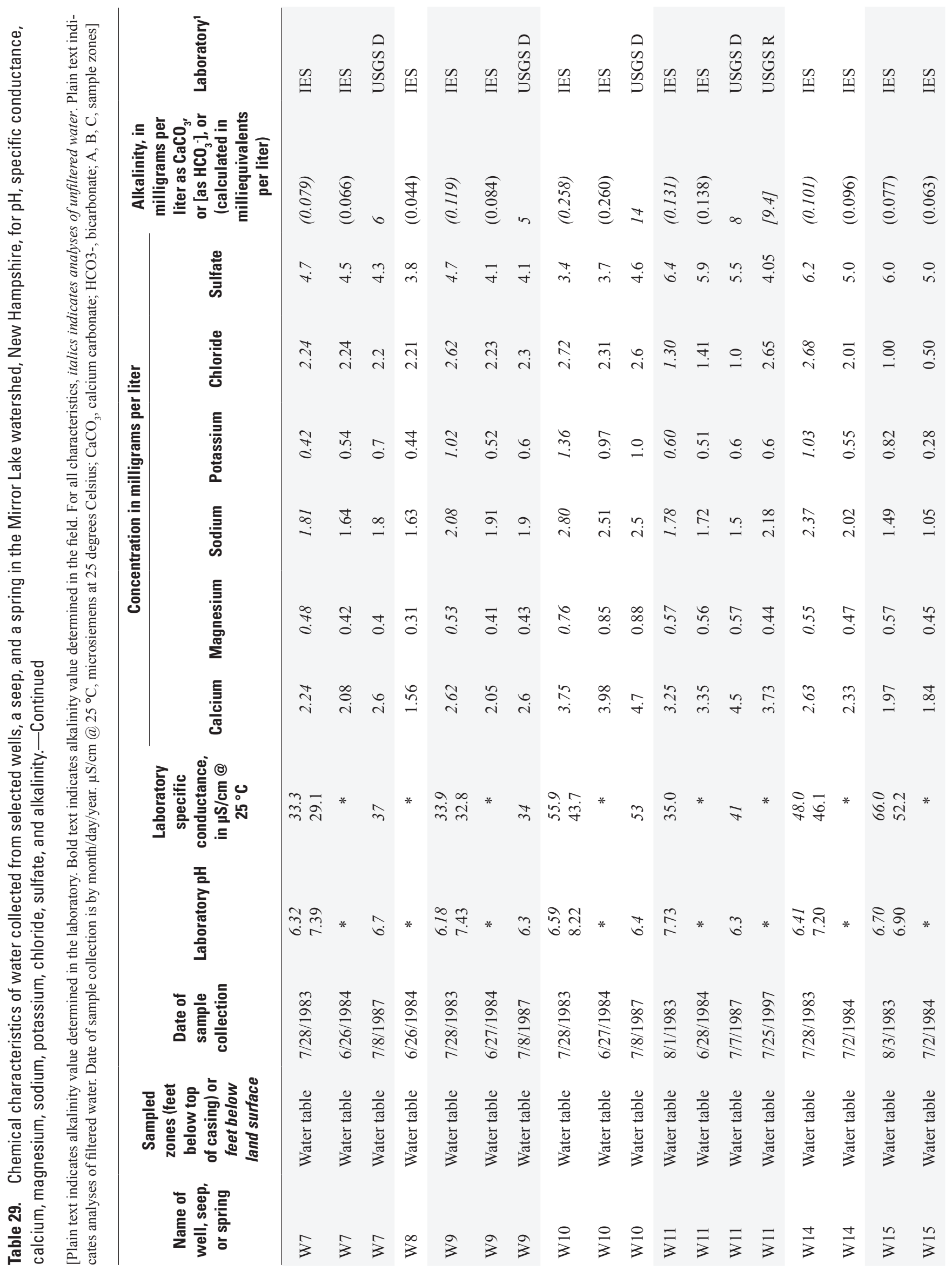




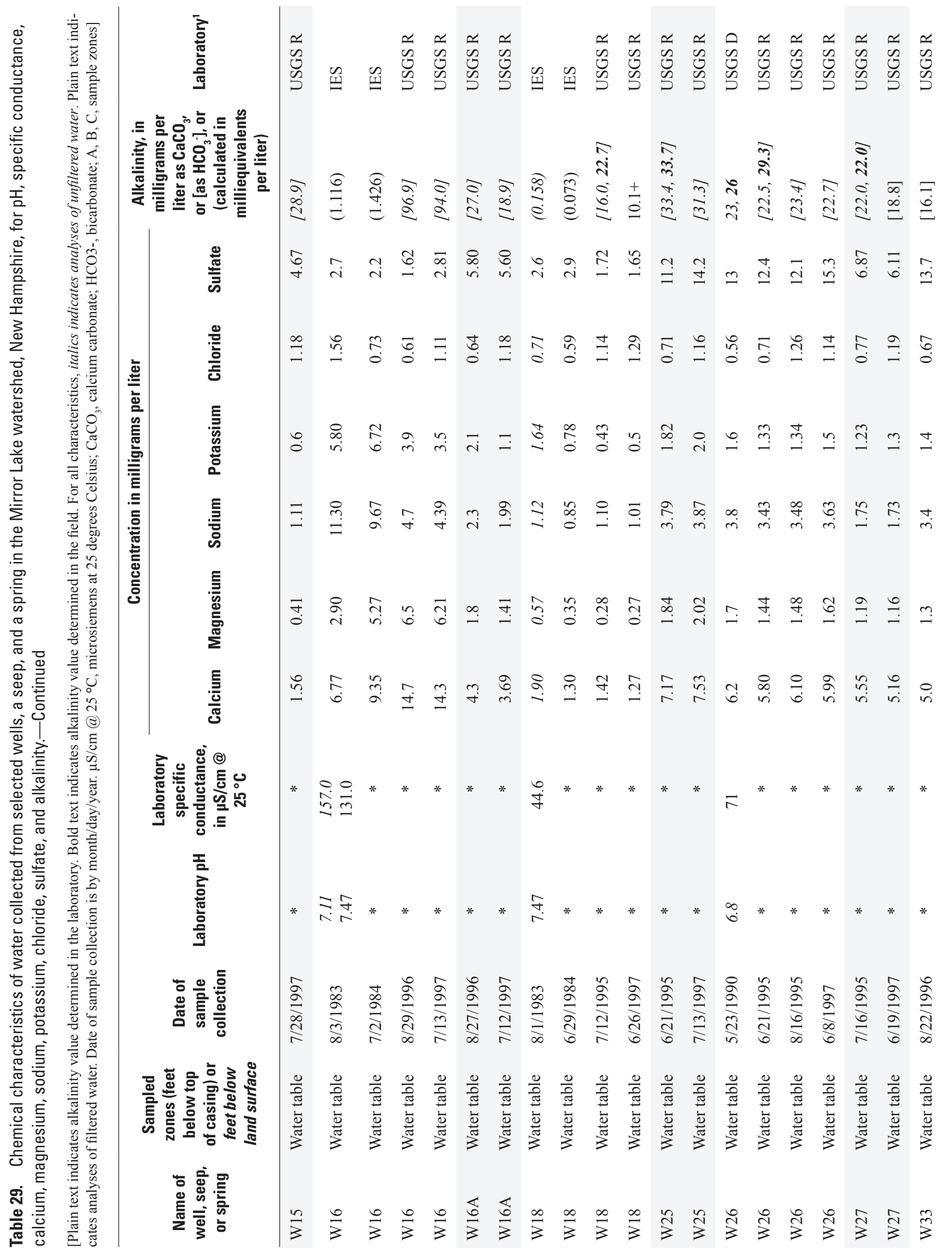




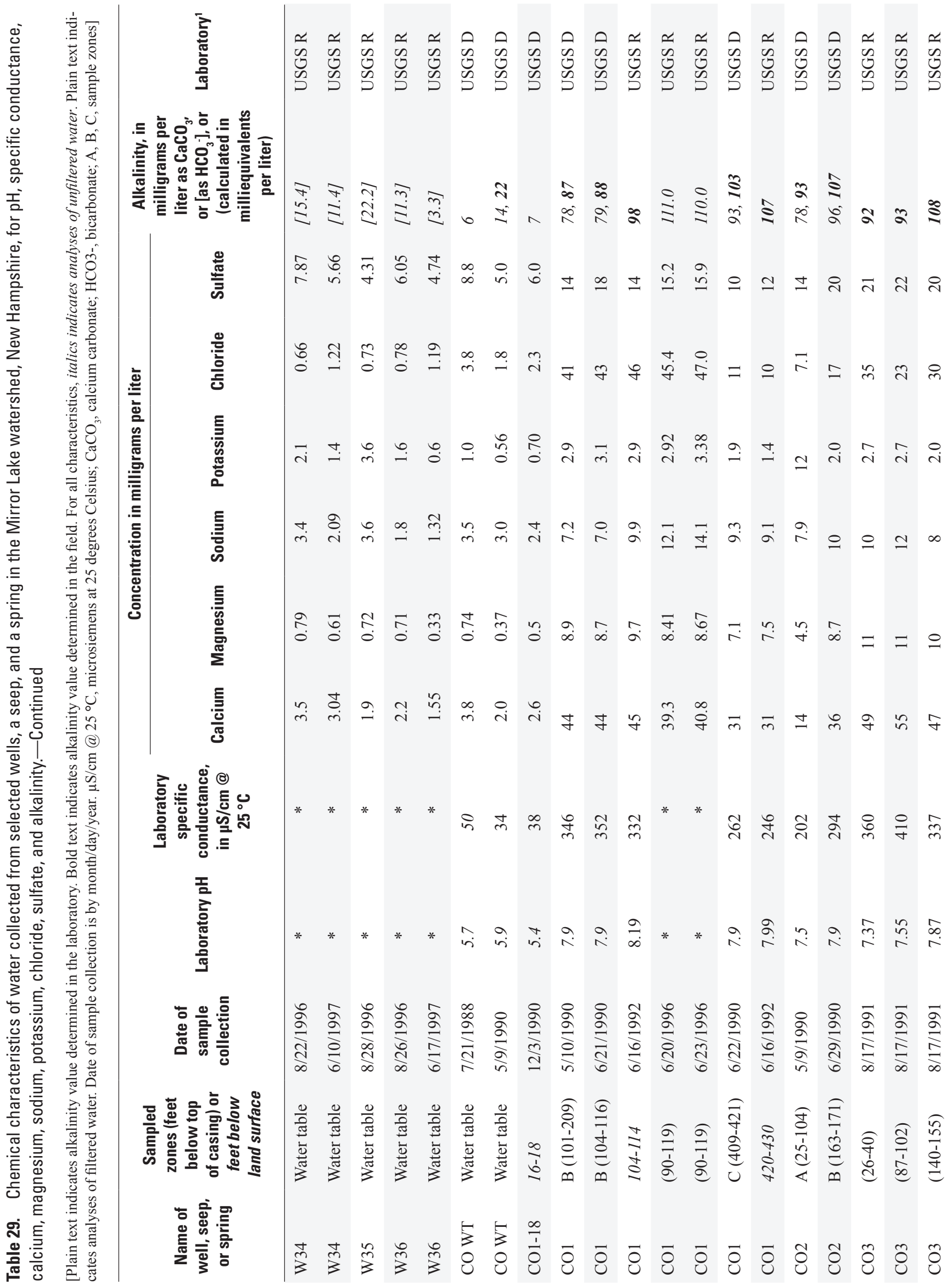




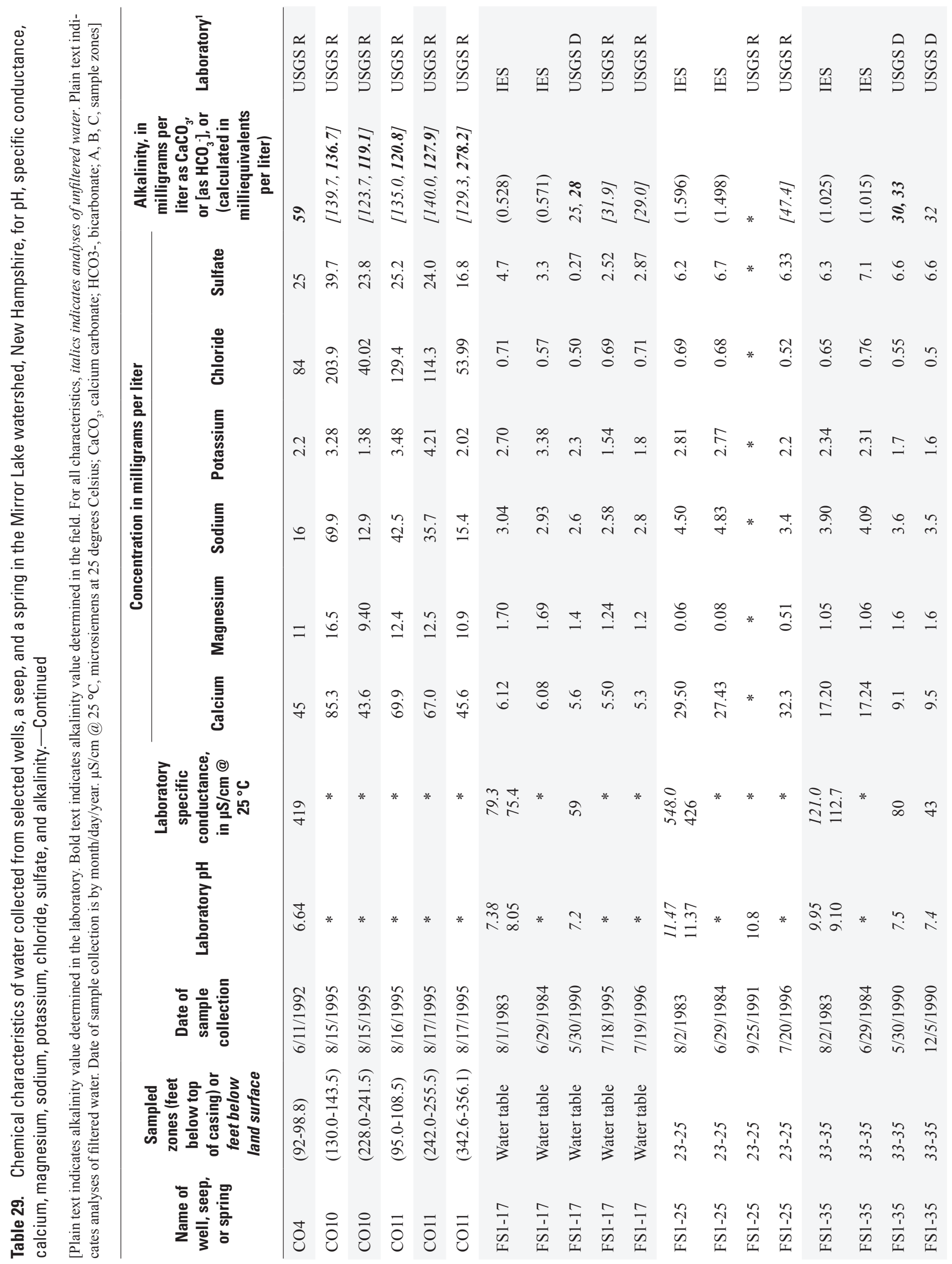




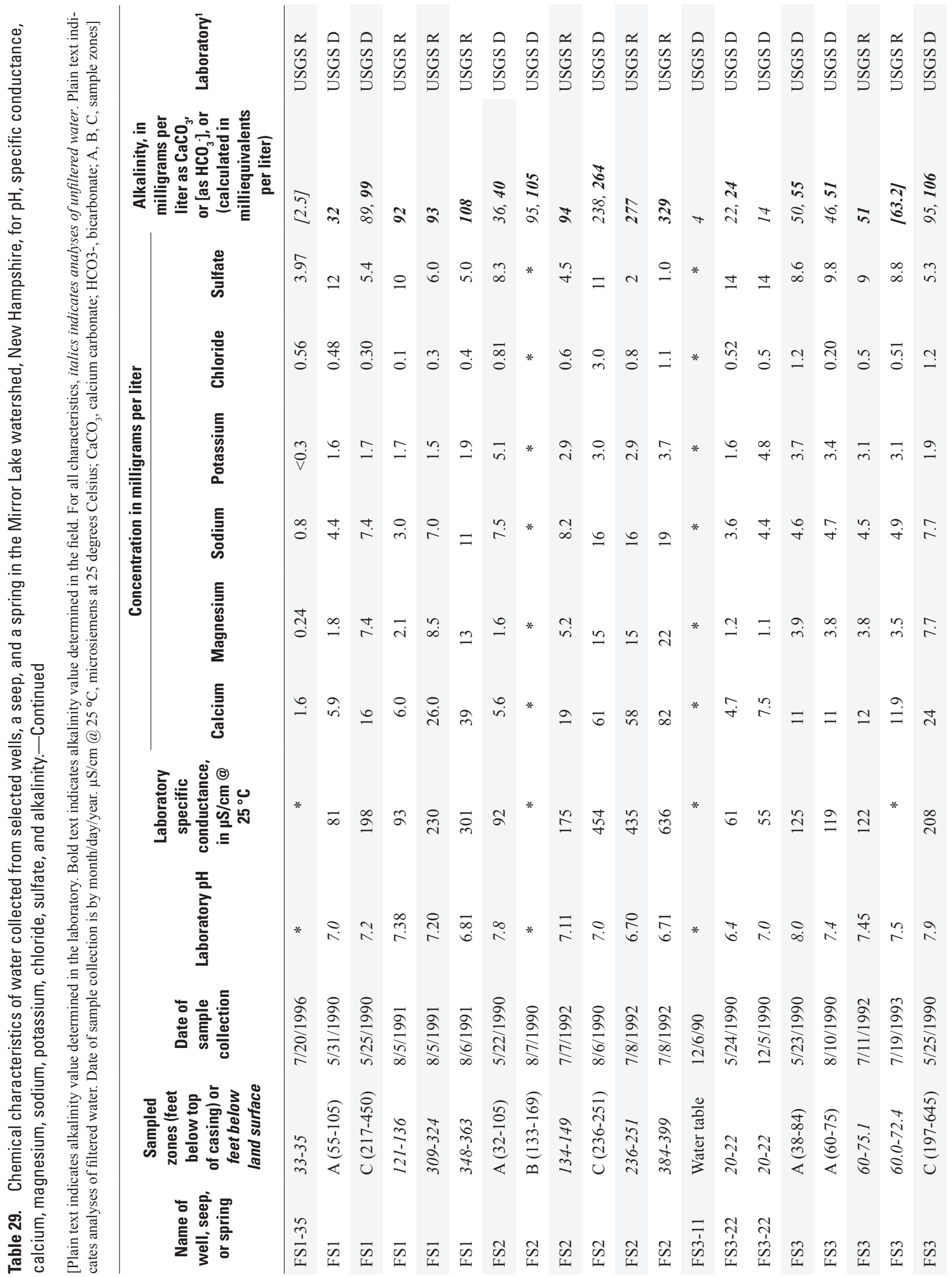




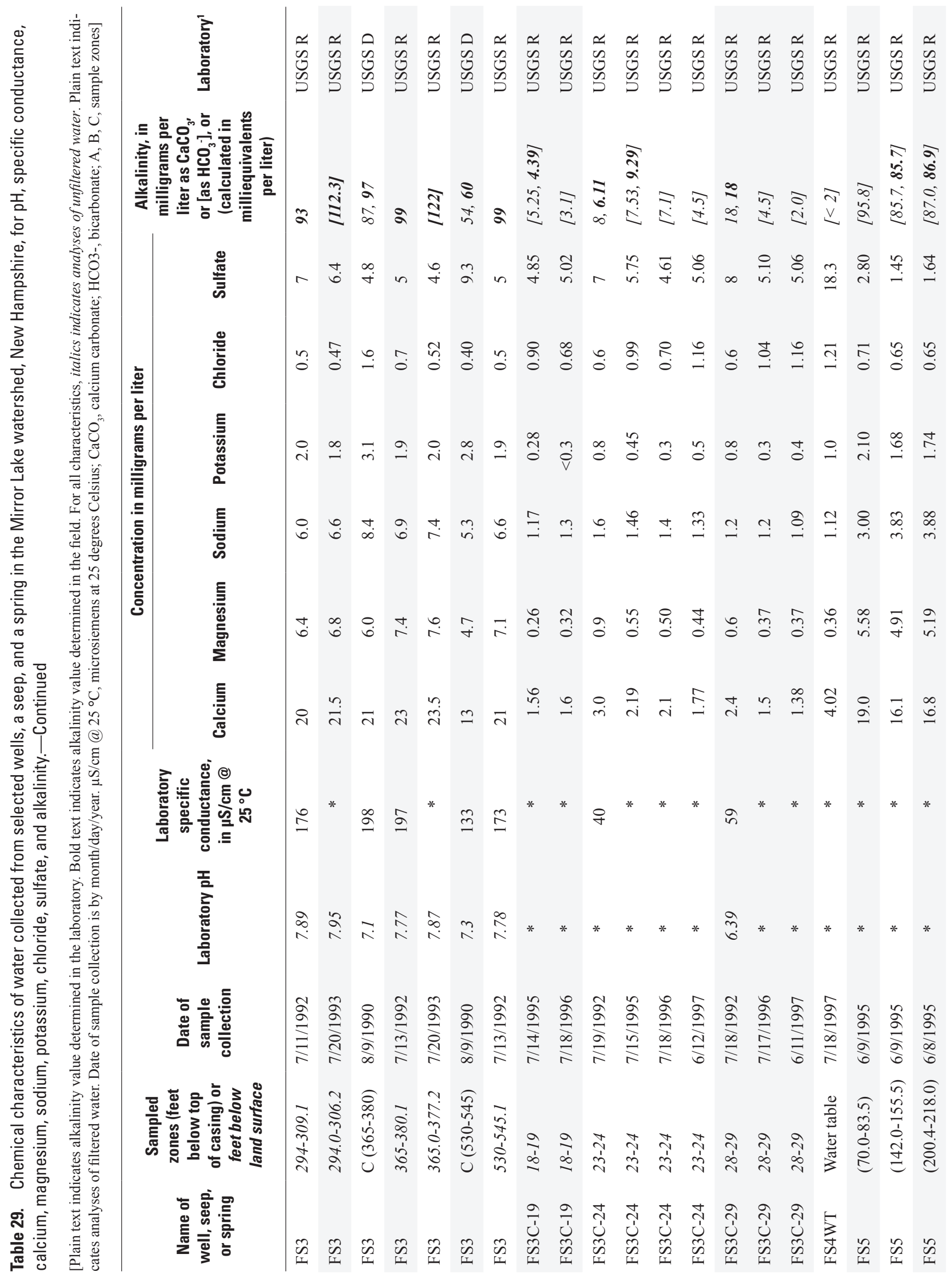




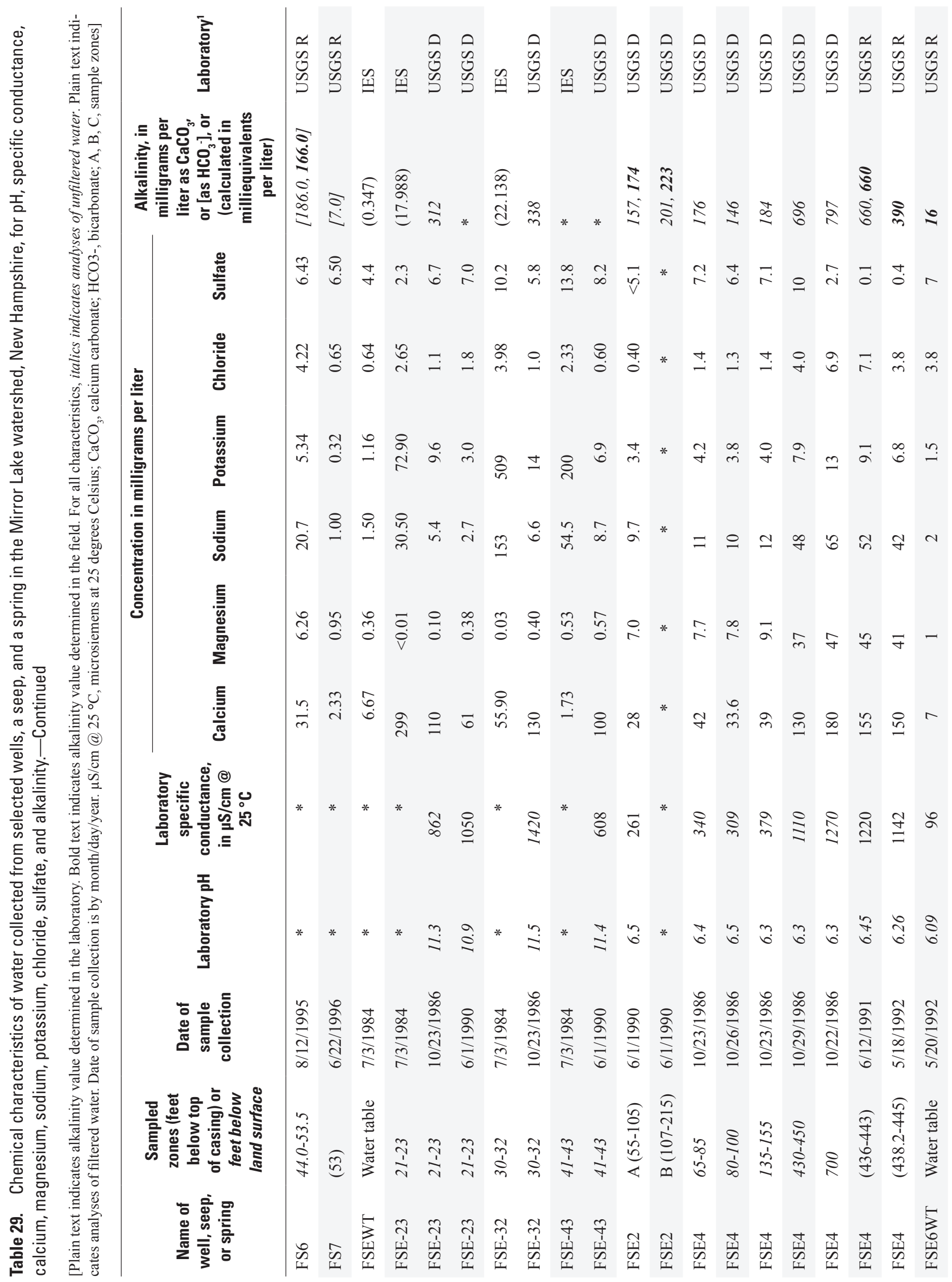




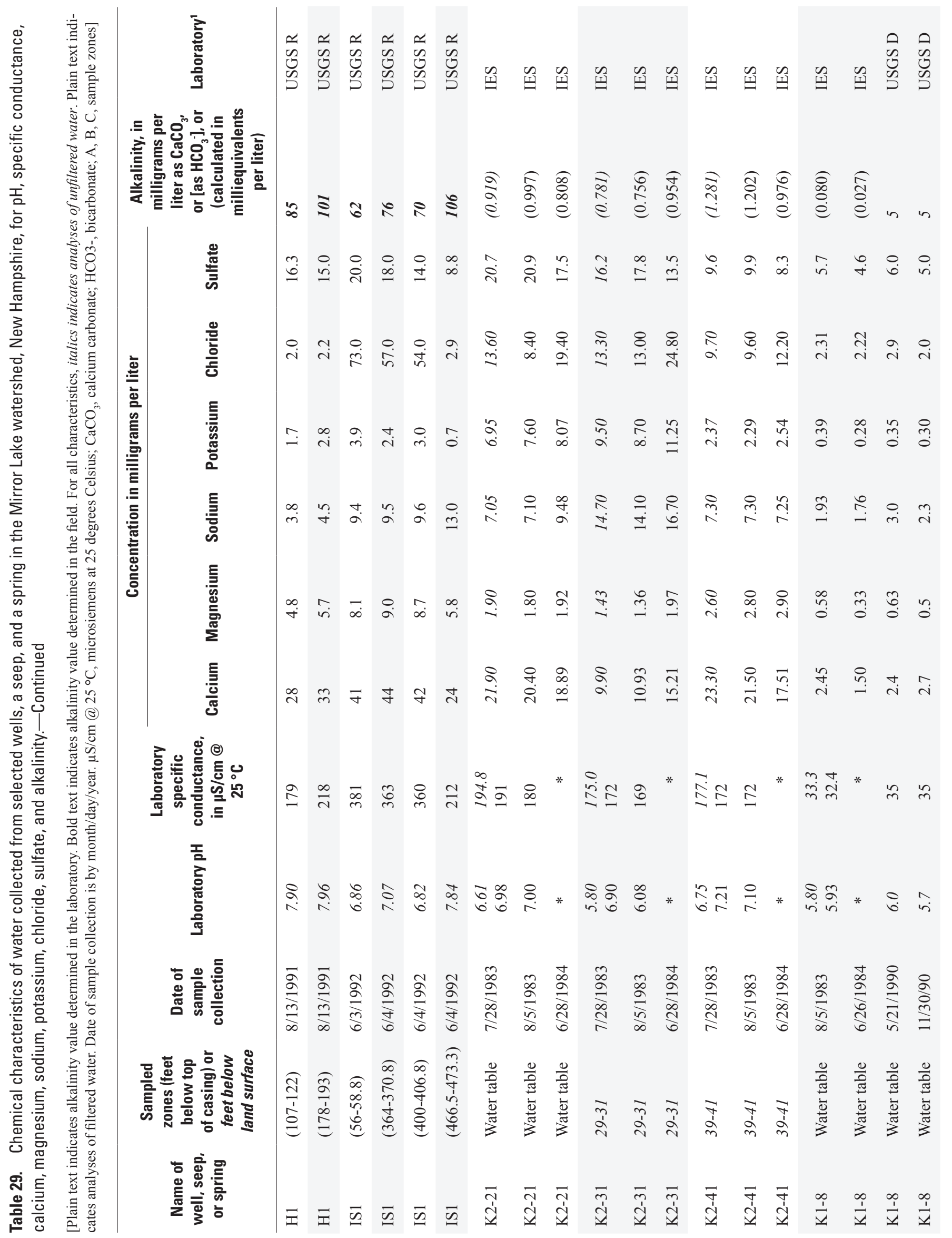




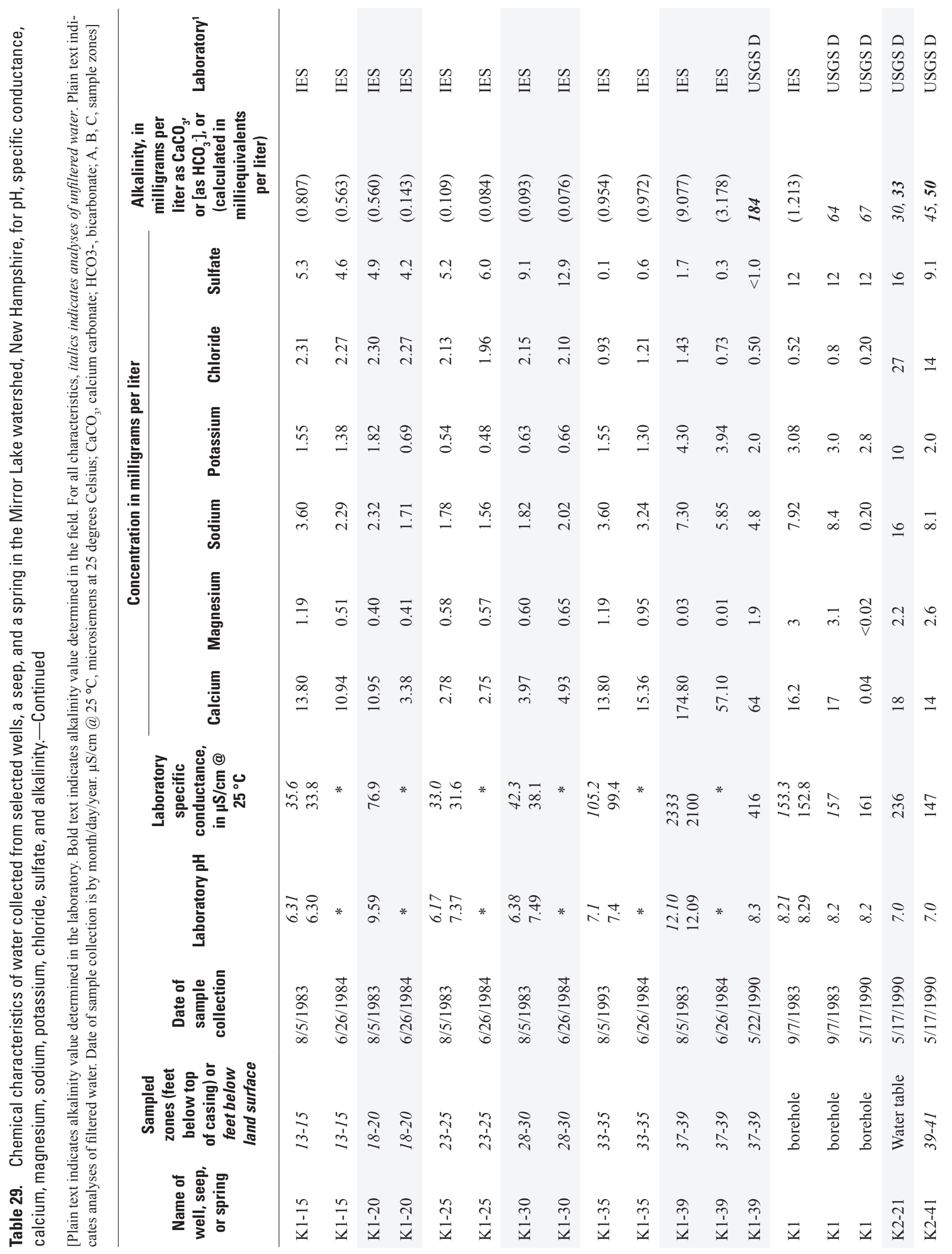




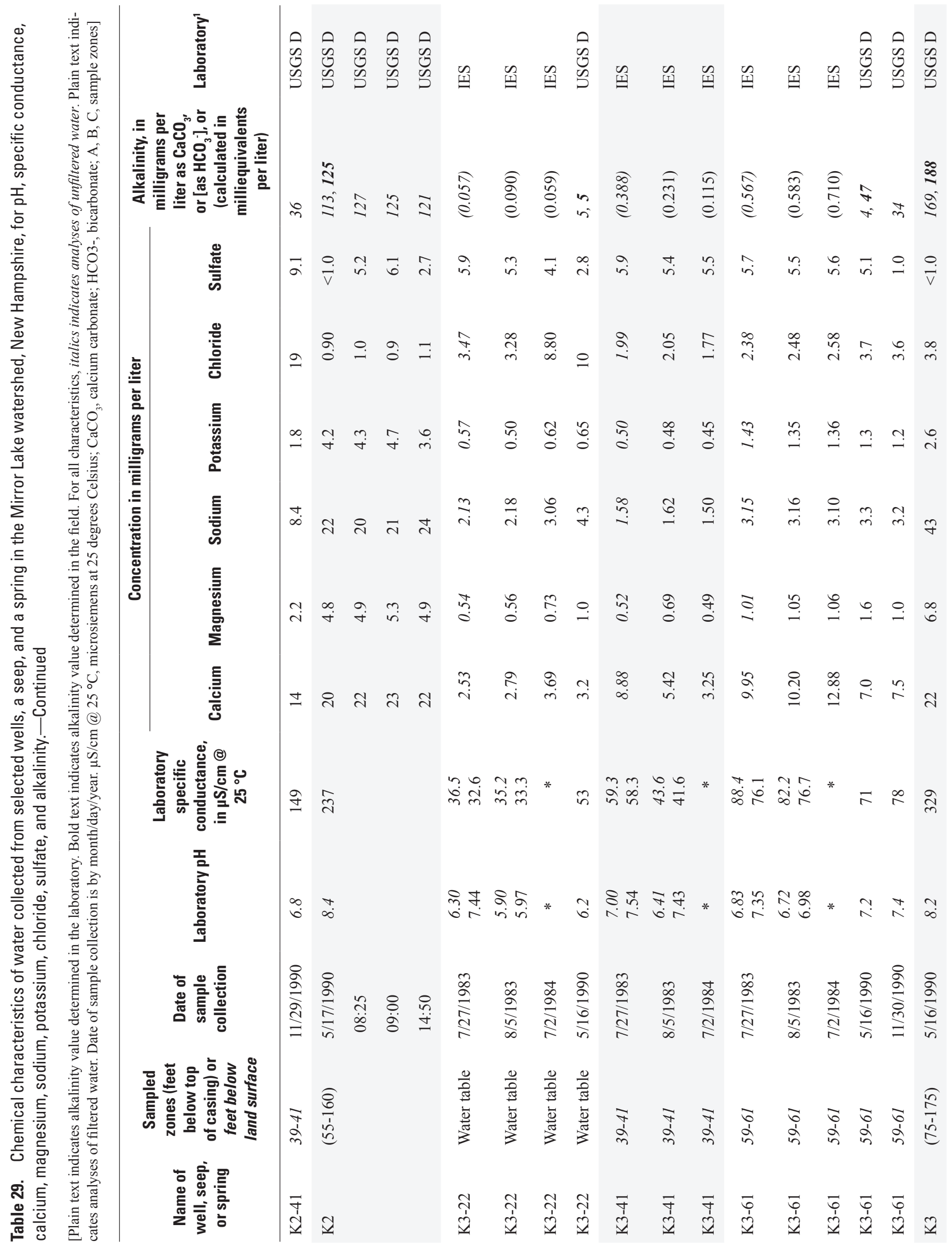




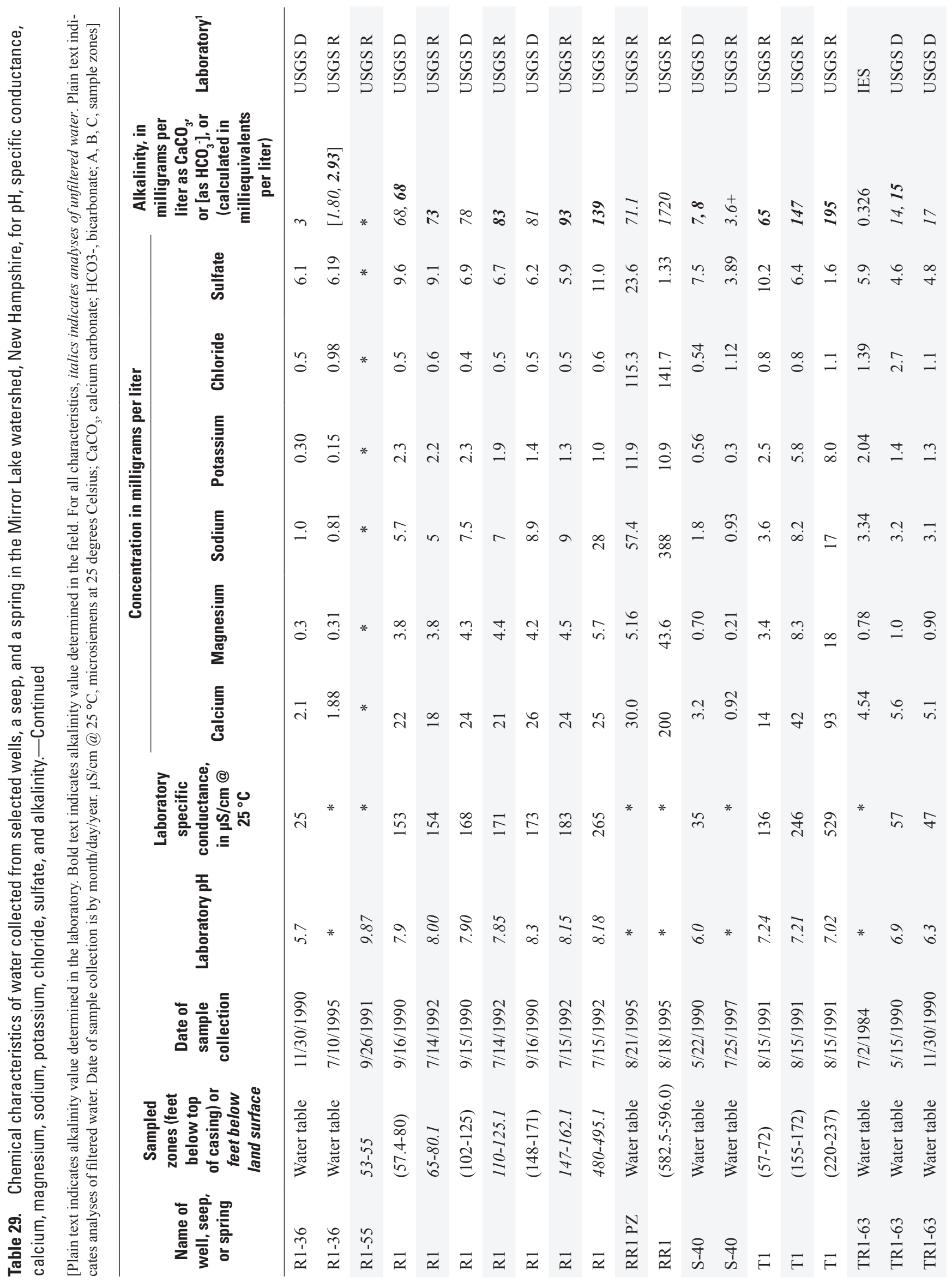




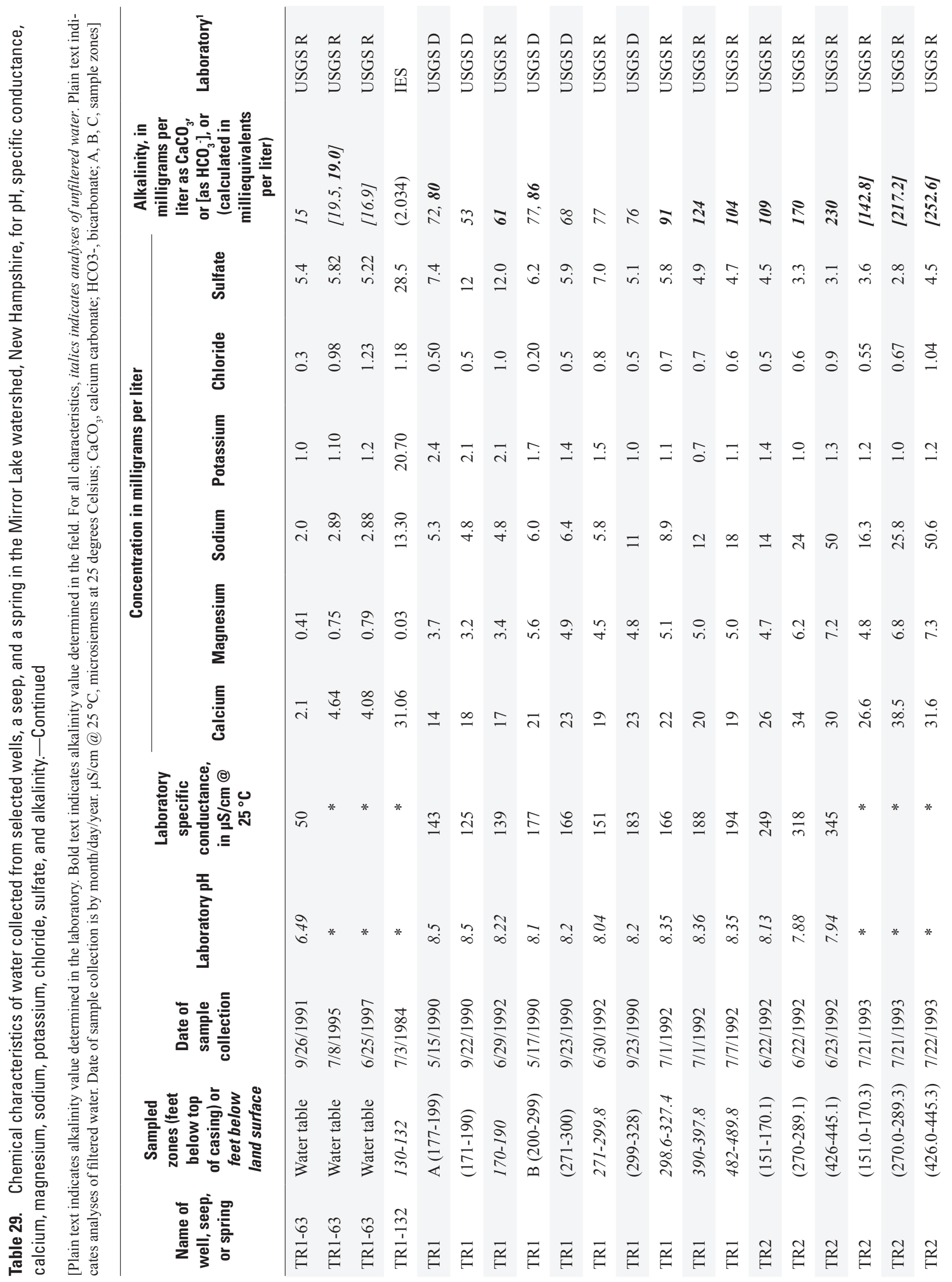


Tables 73
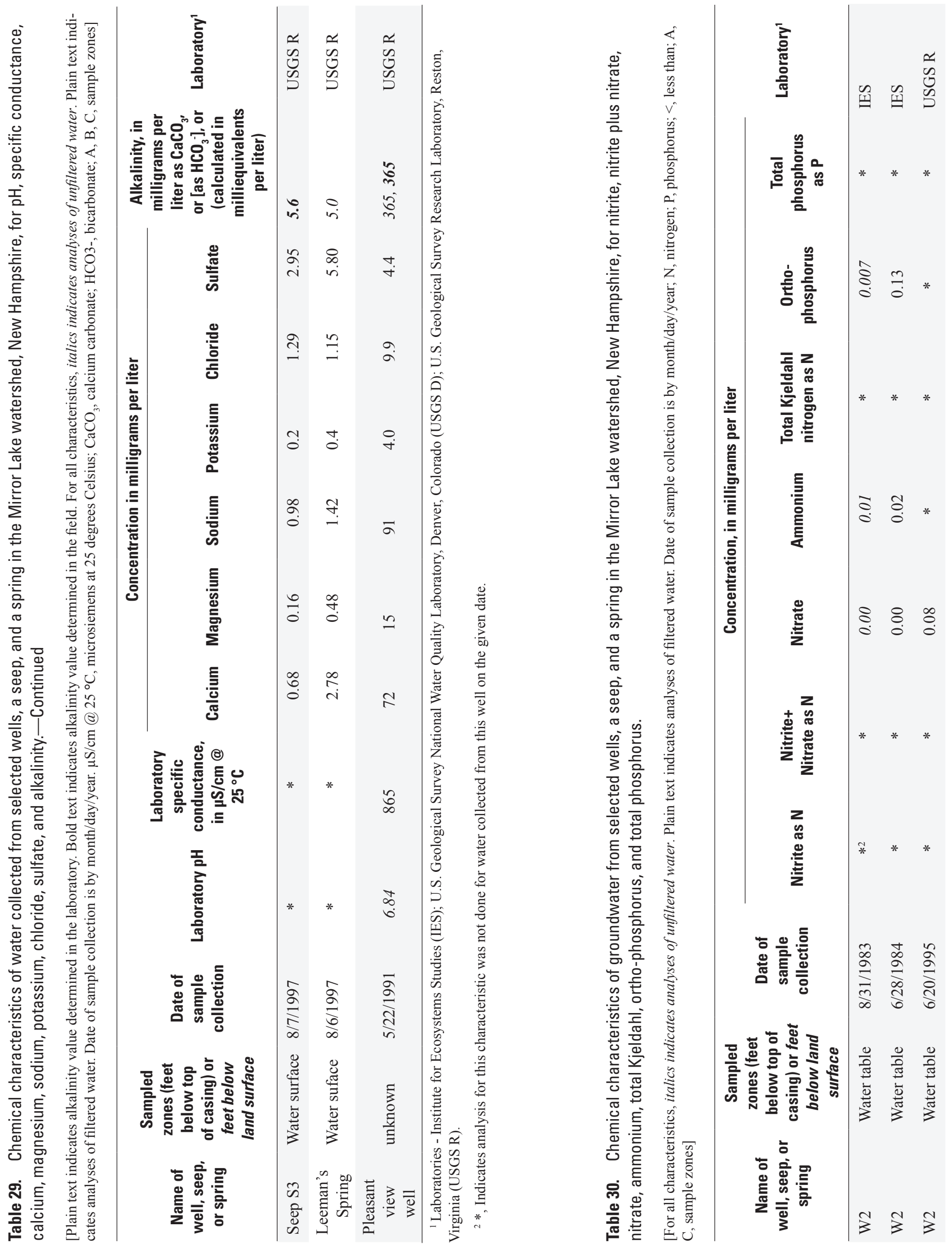


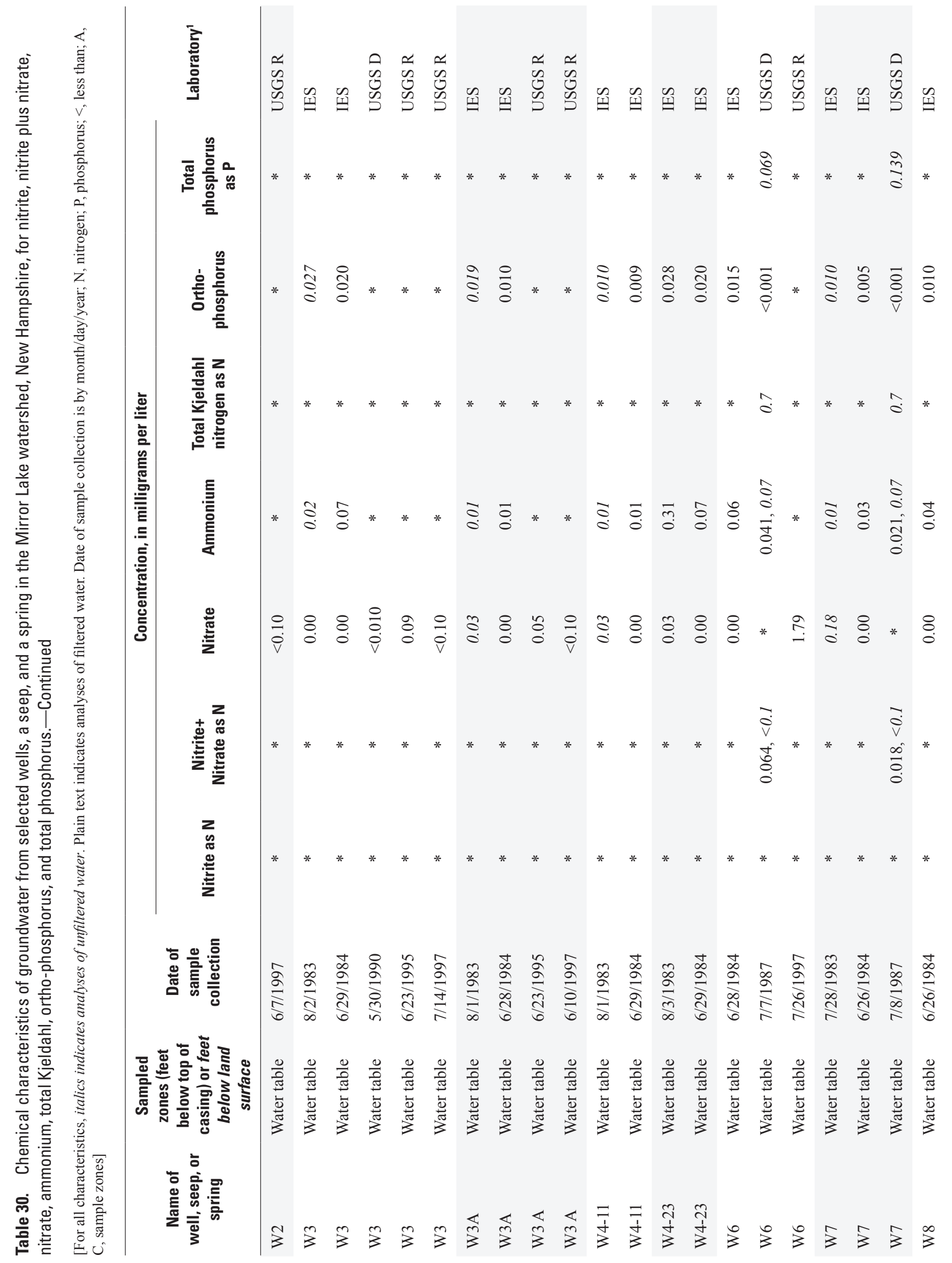




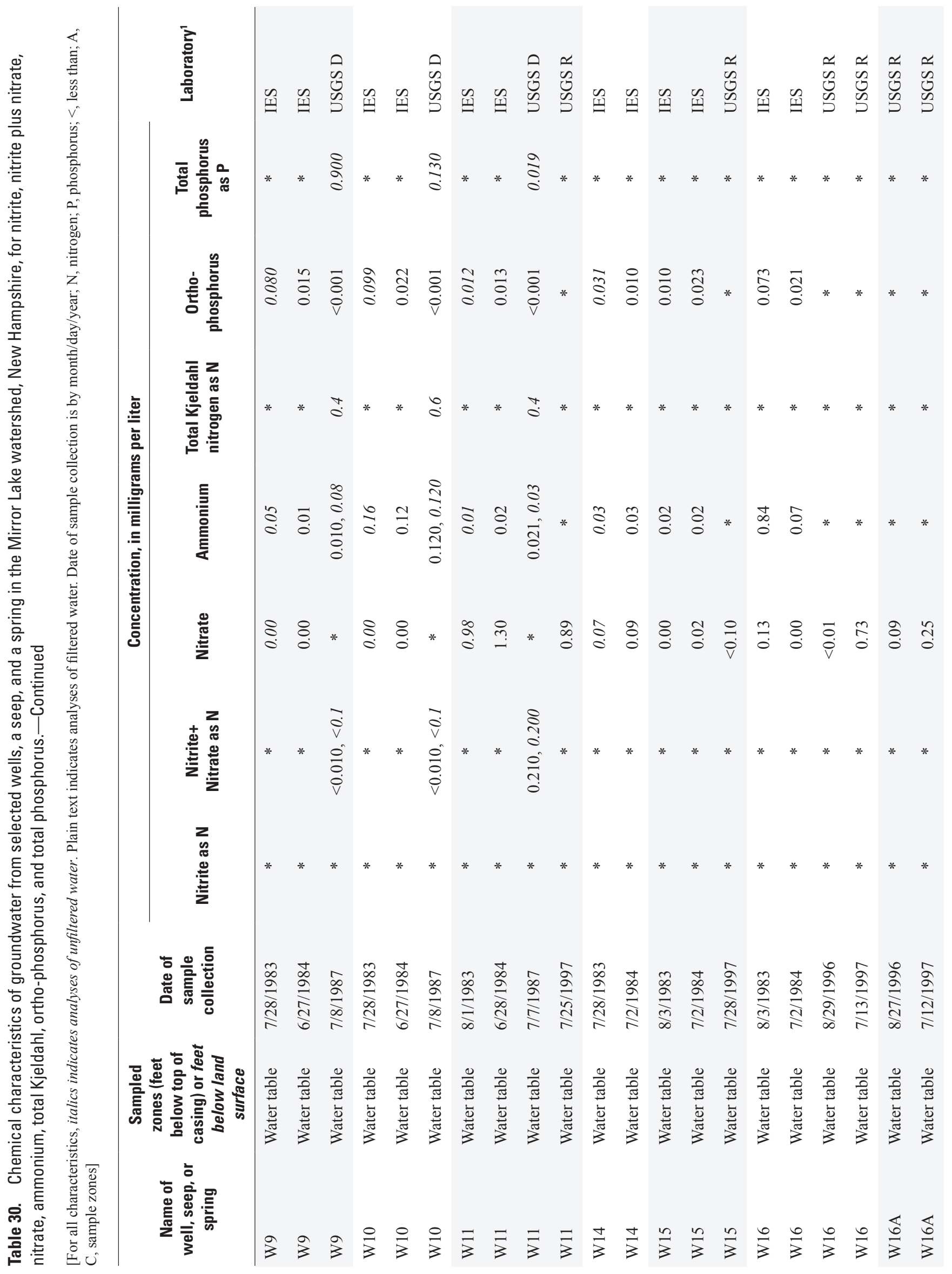




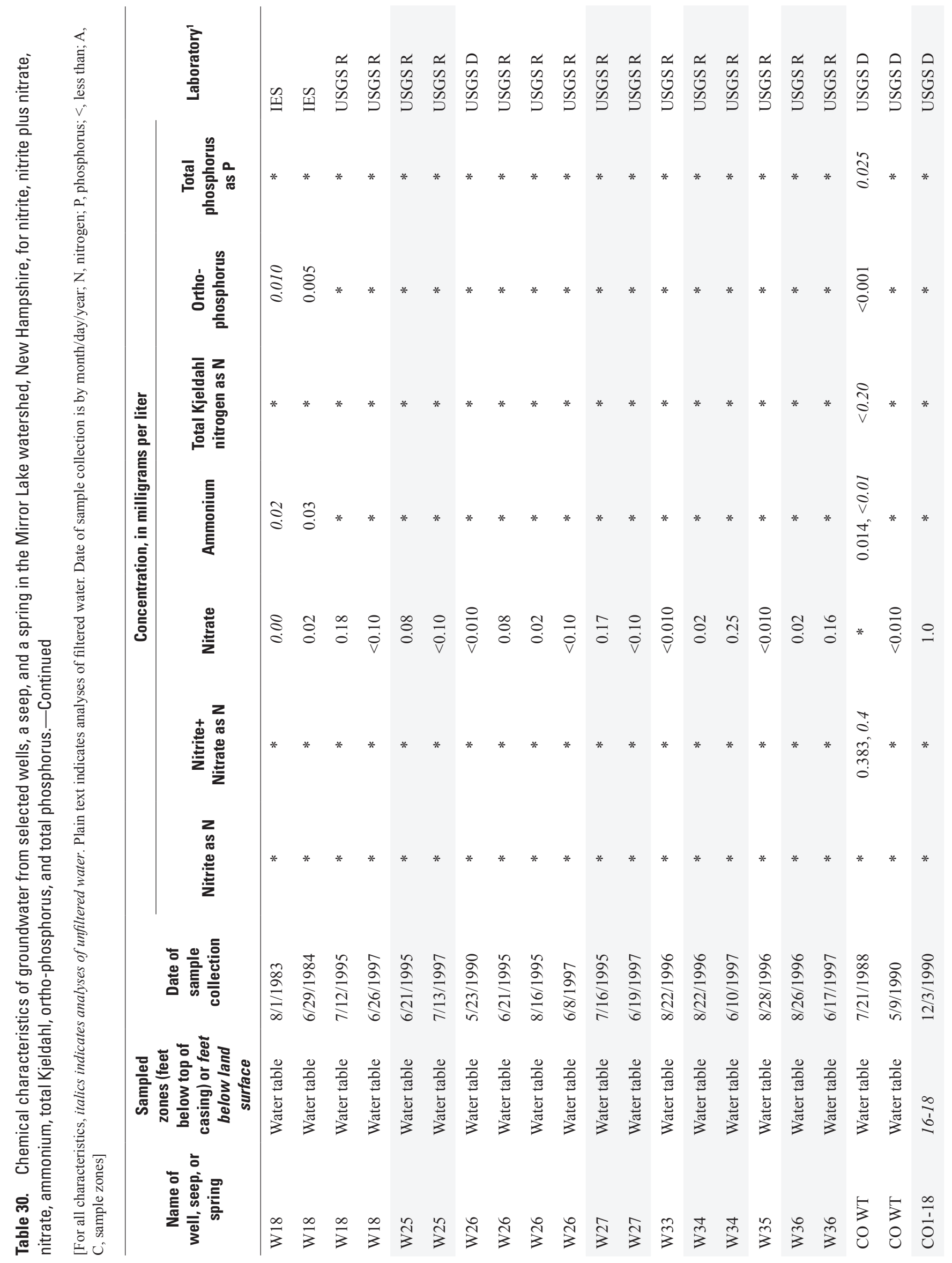


Tables $\quad 77$

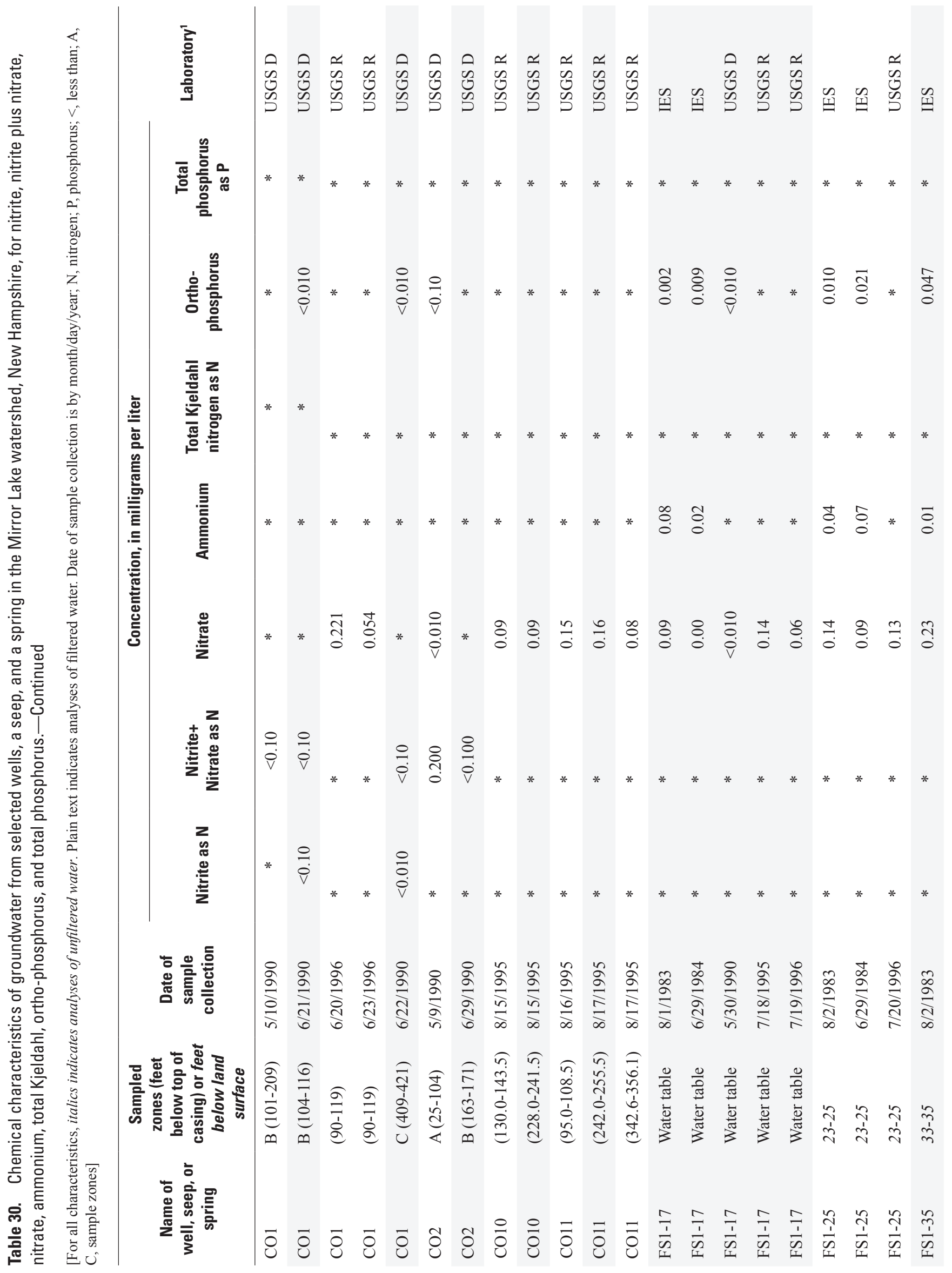




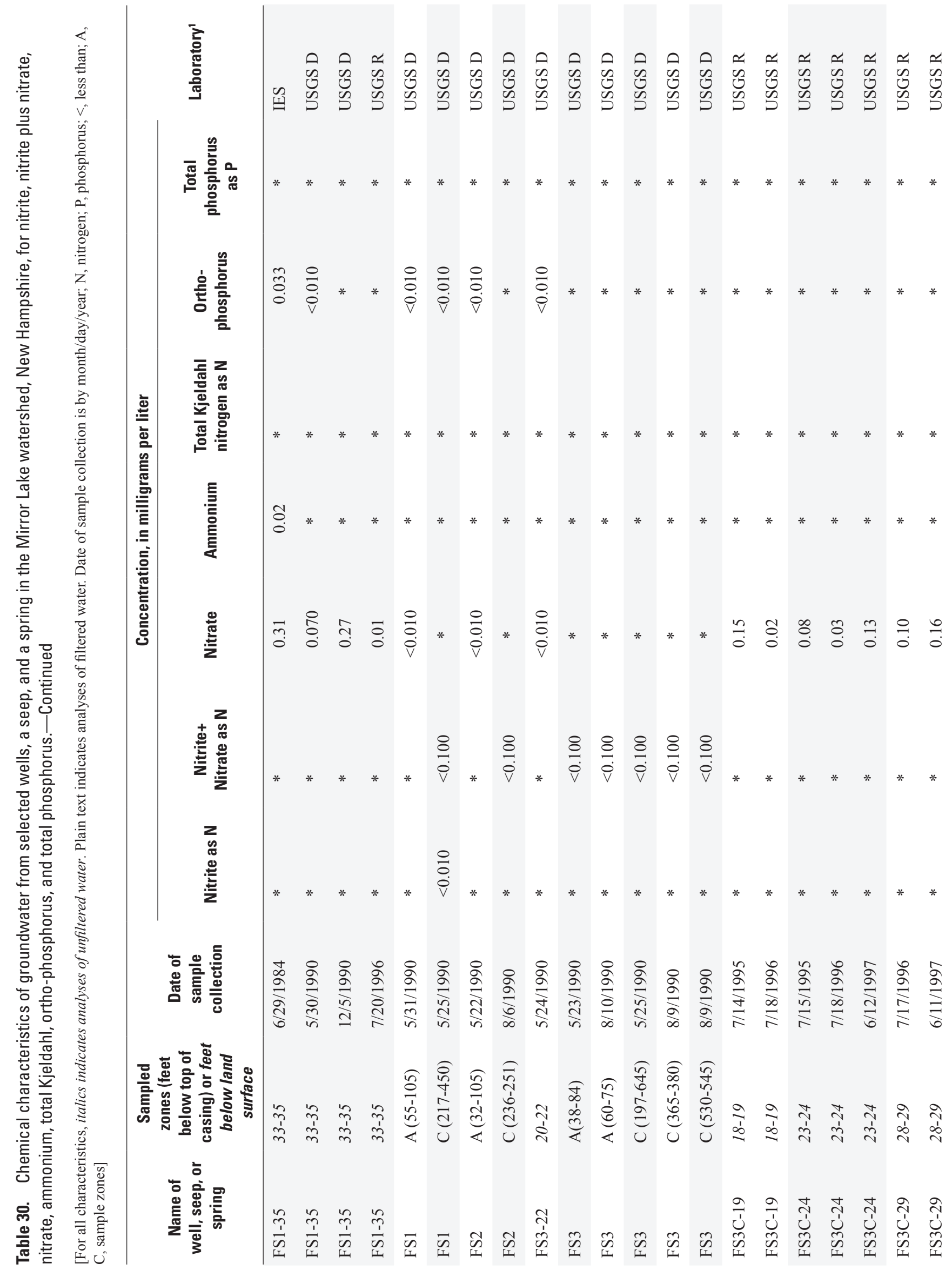




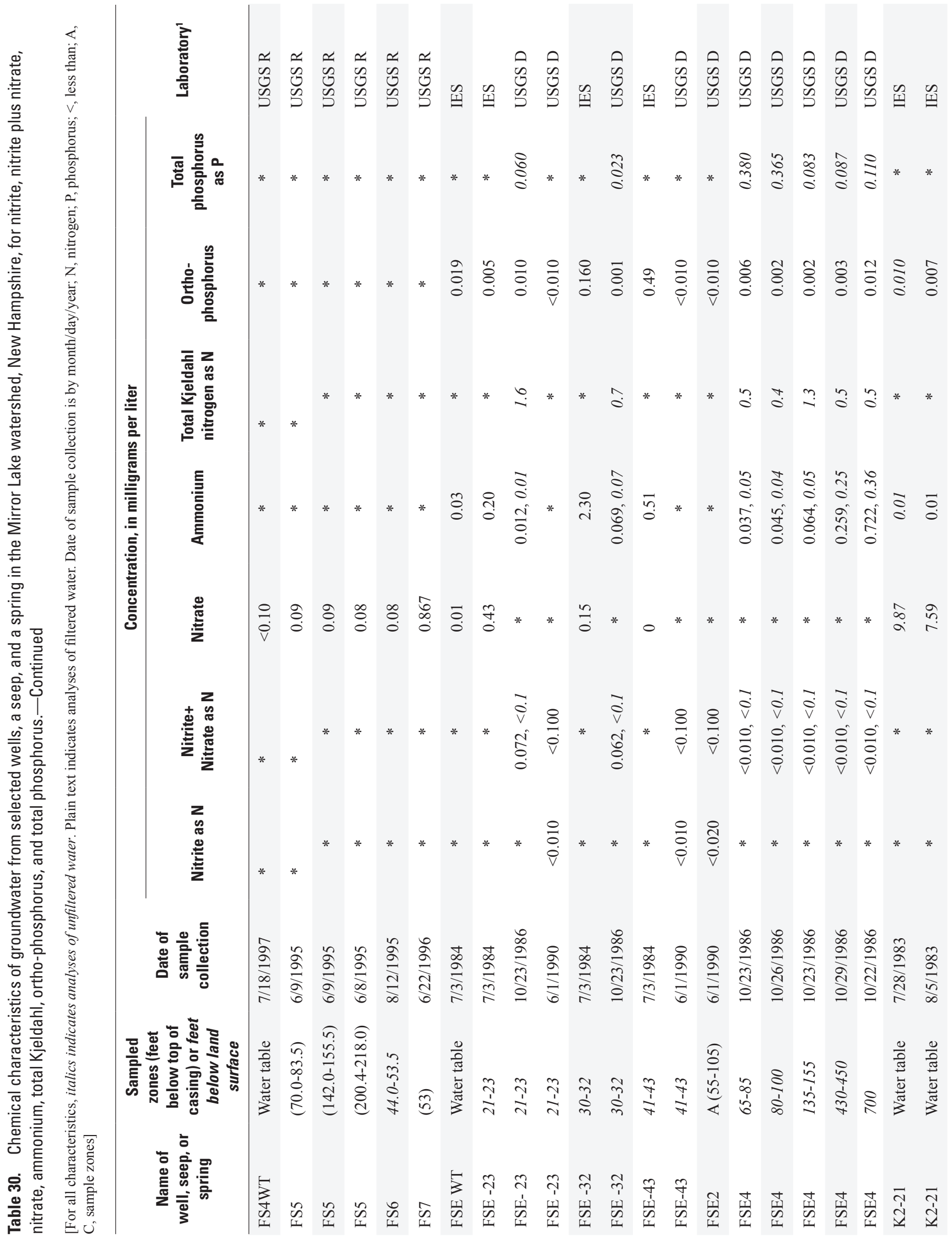




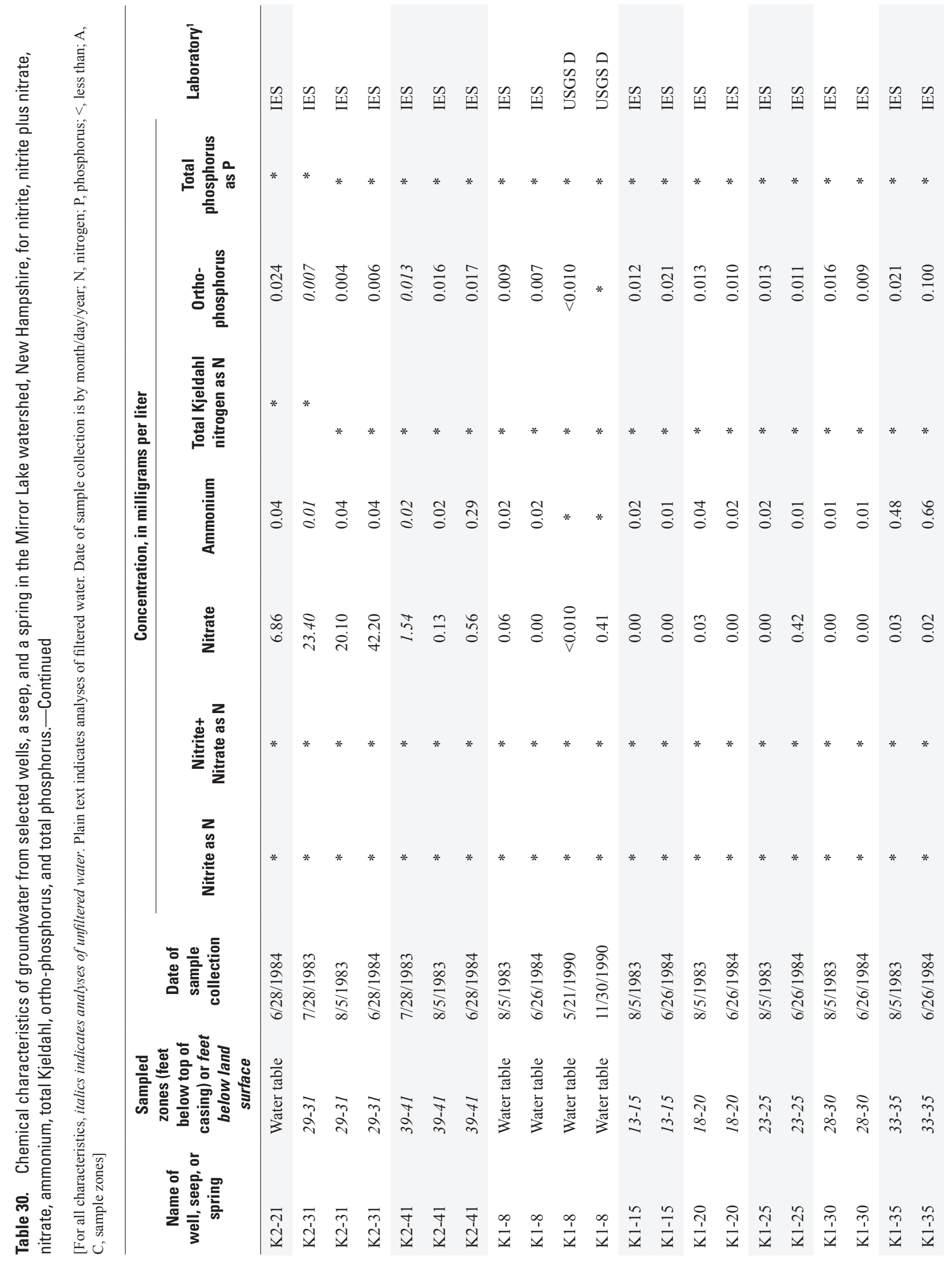


Tables $\quad 81$

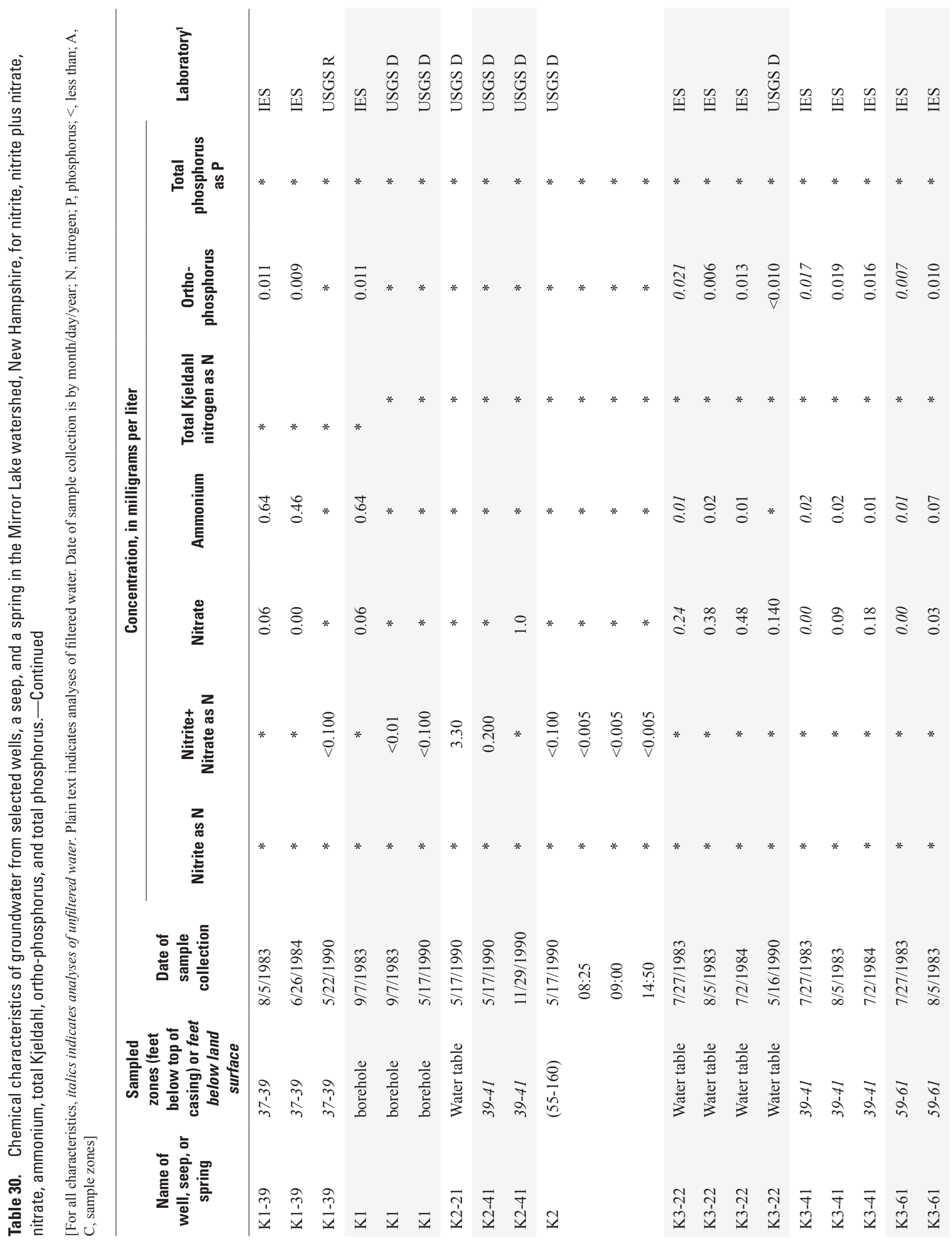




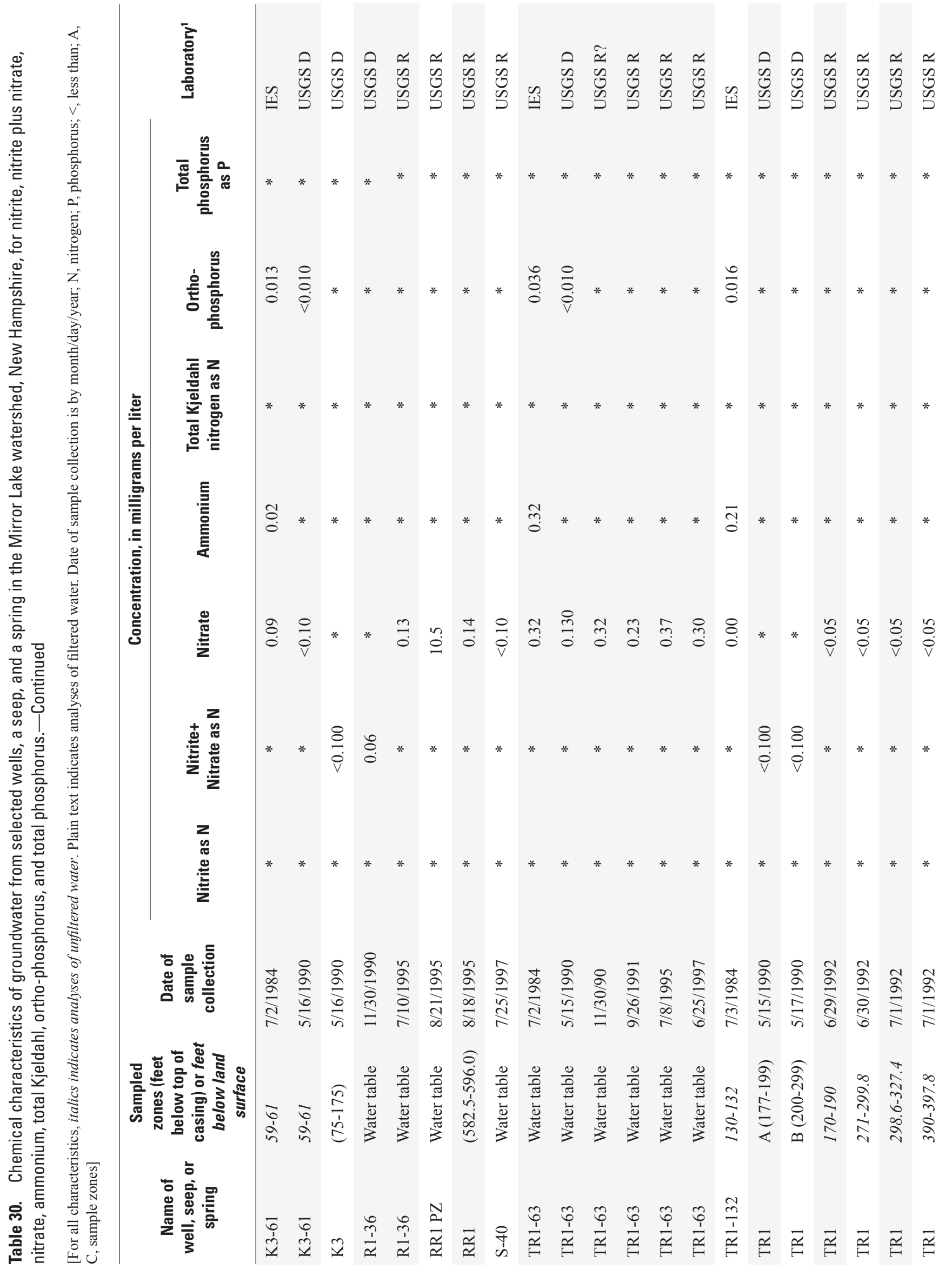


Tables $\quad 83$
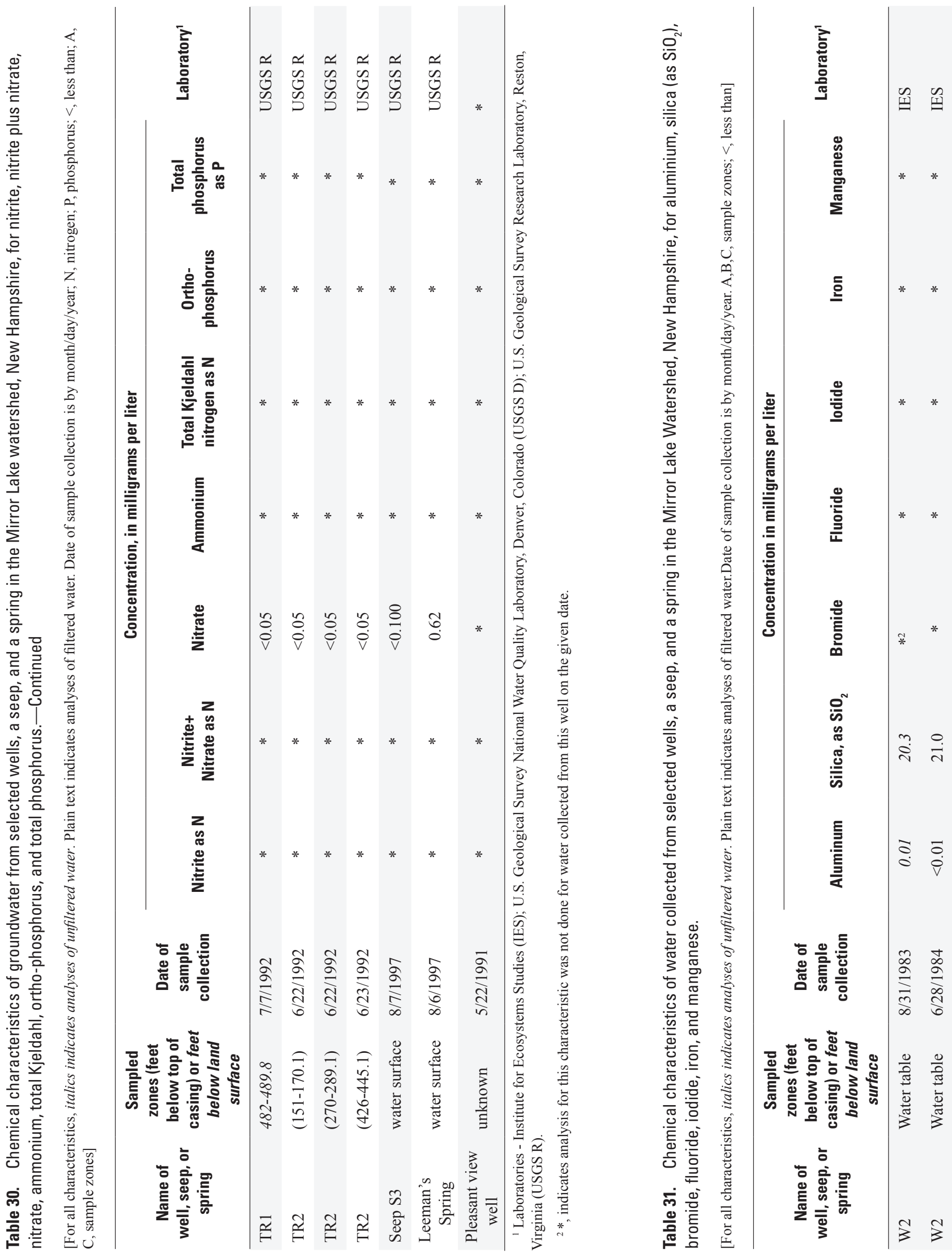


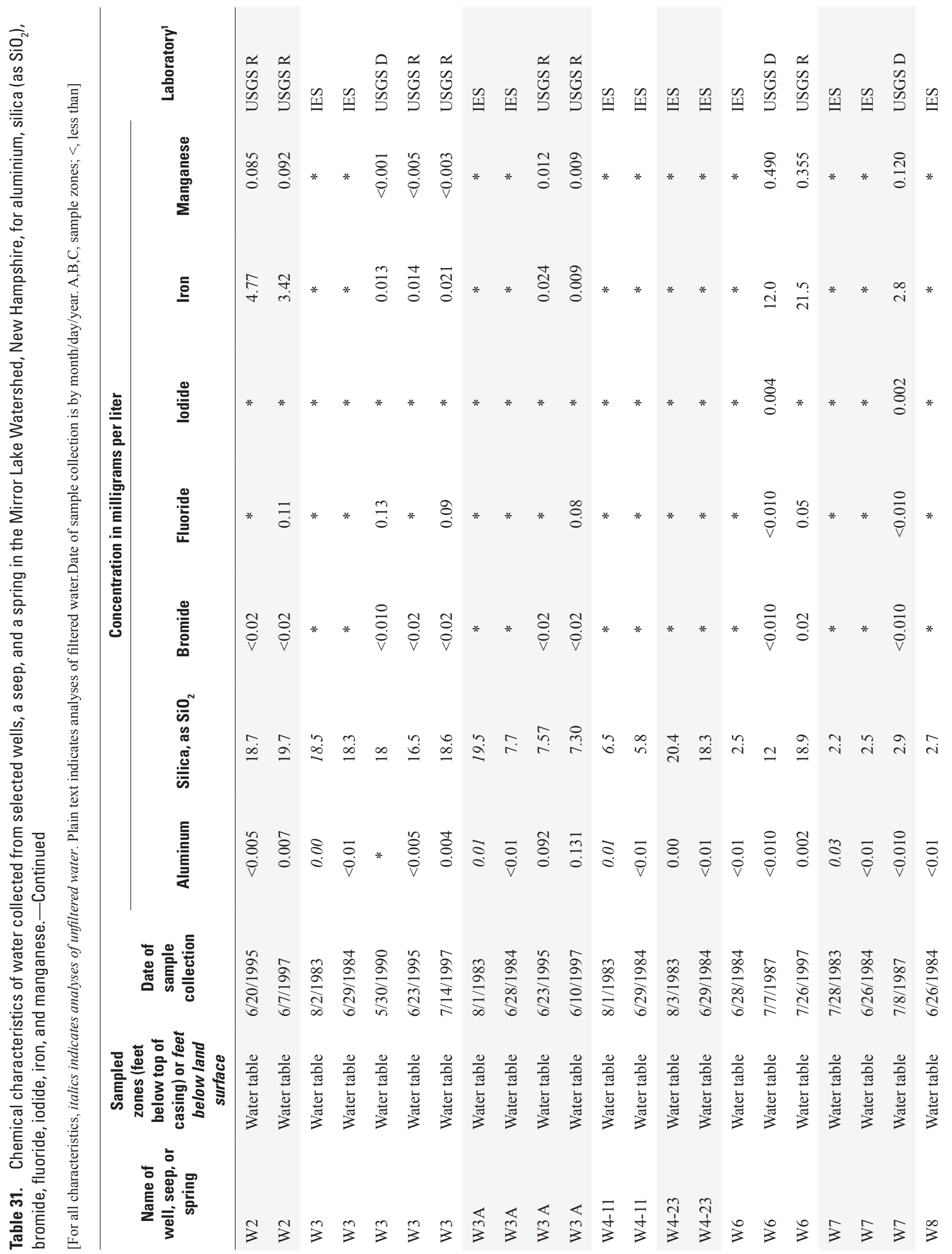




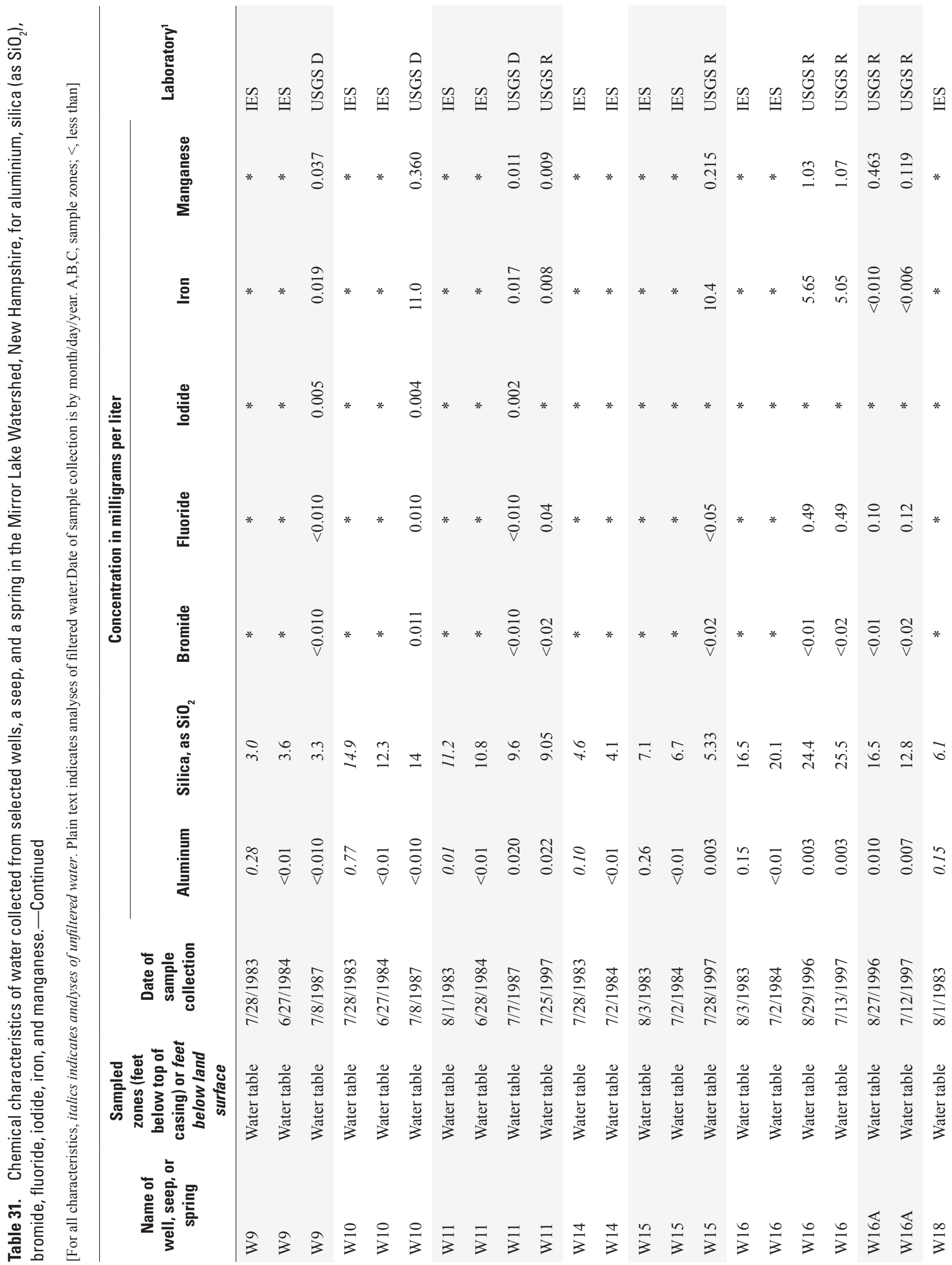




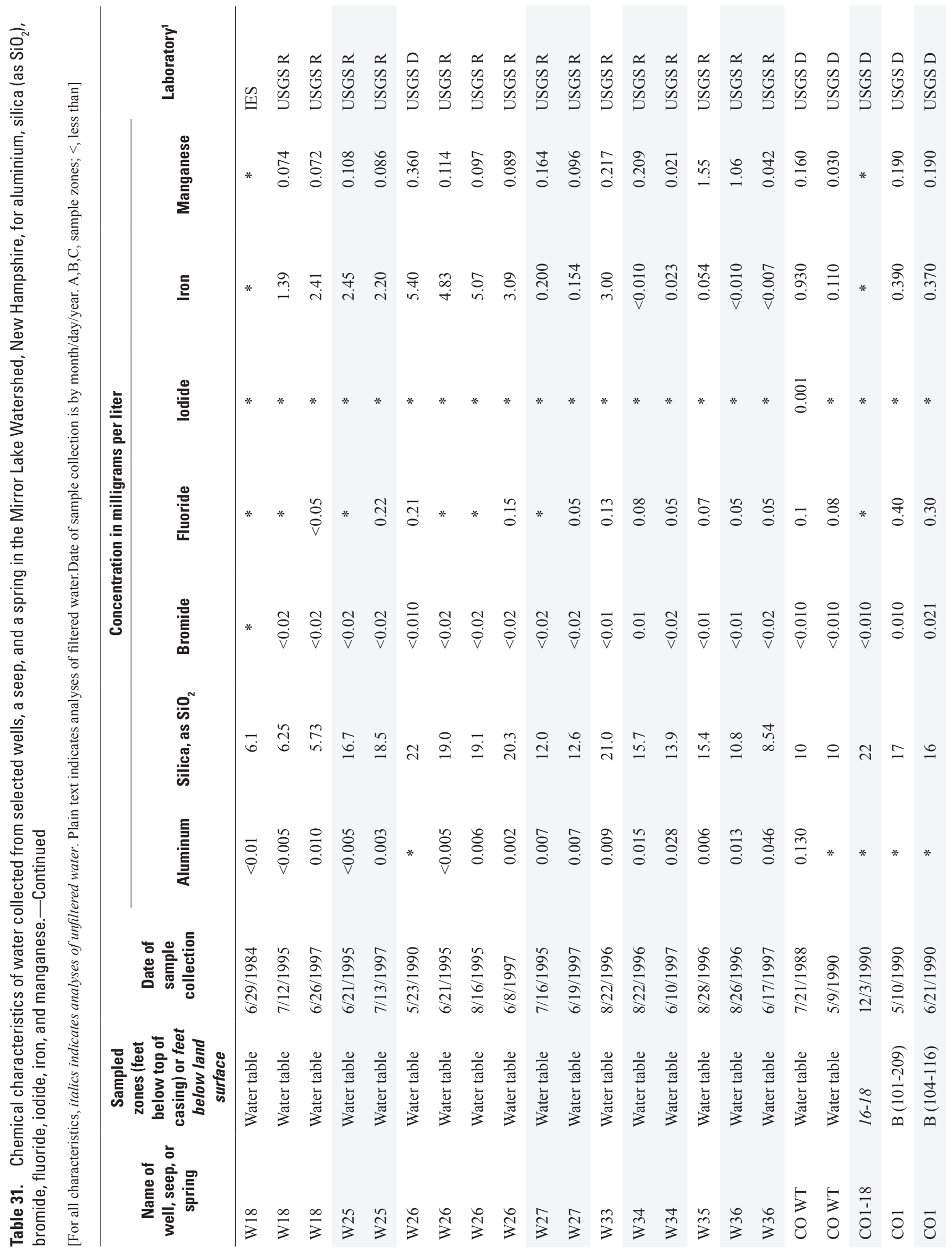


Tables $\quad 87$

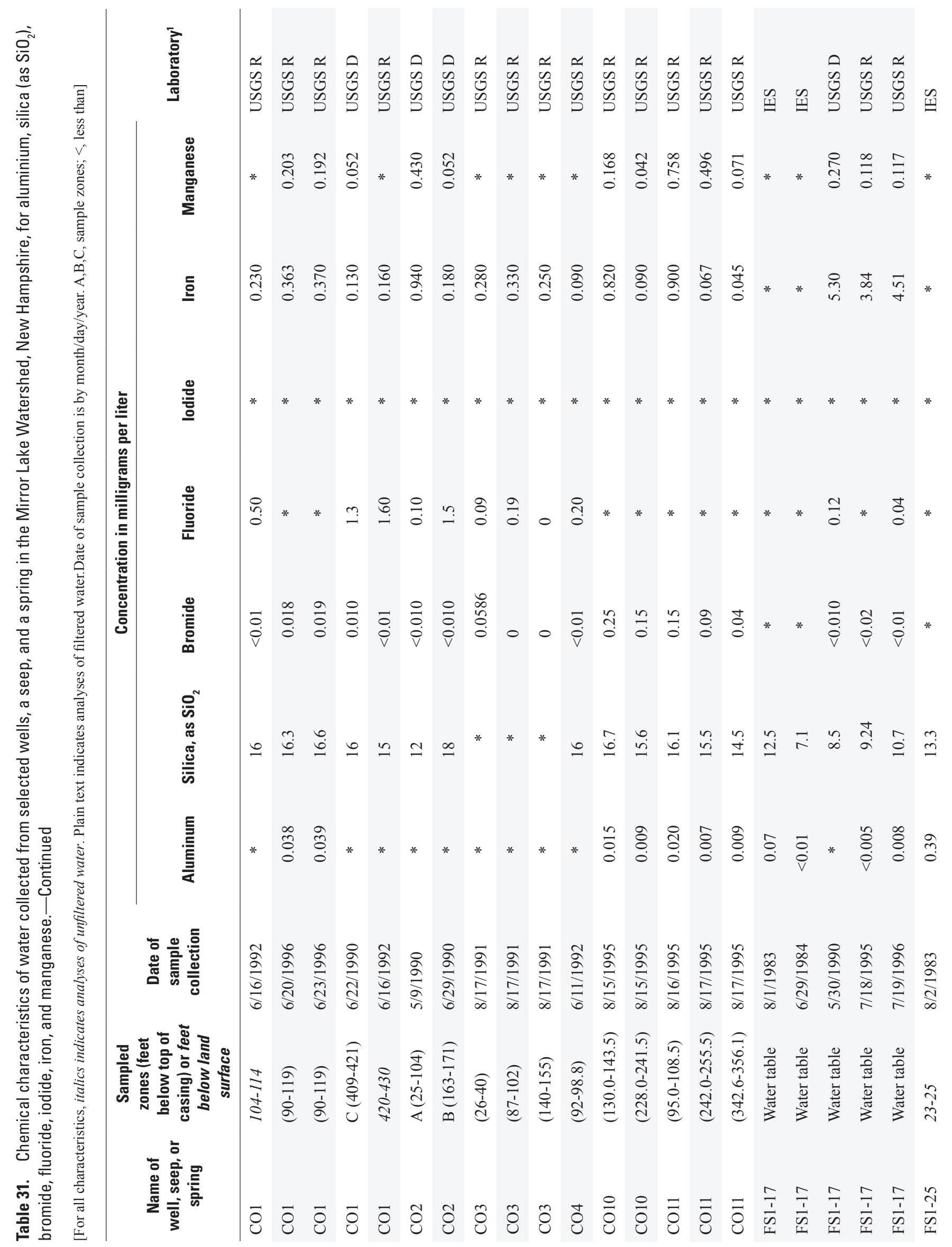




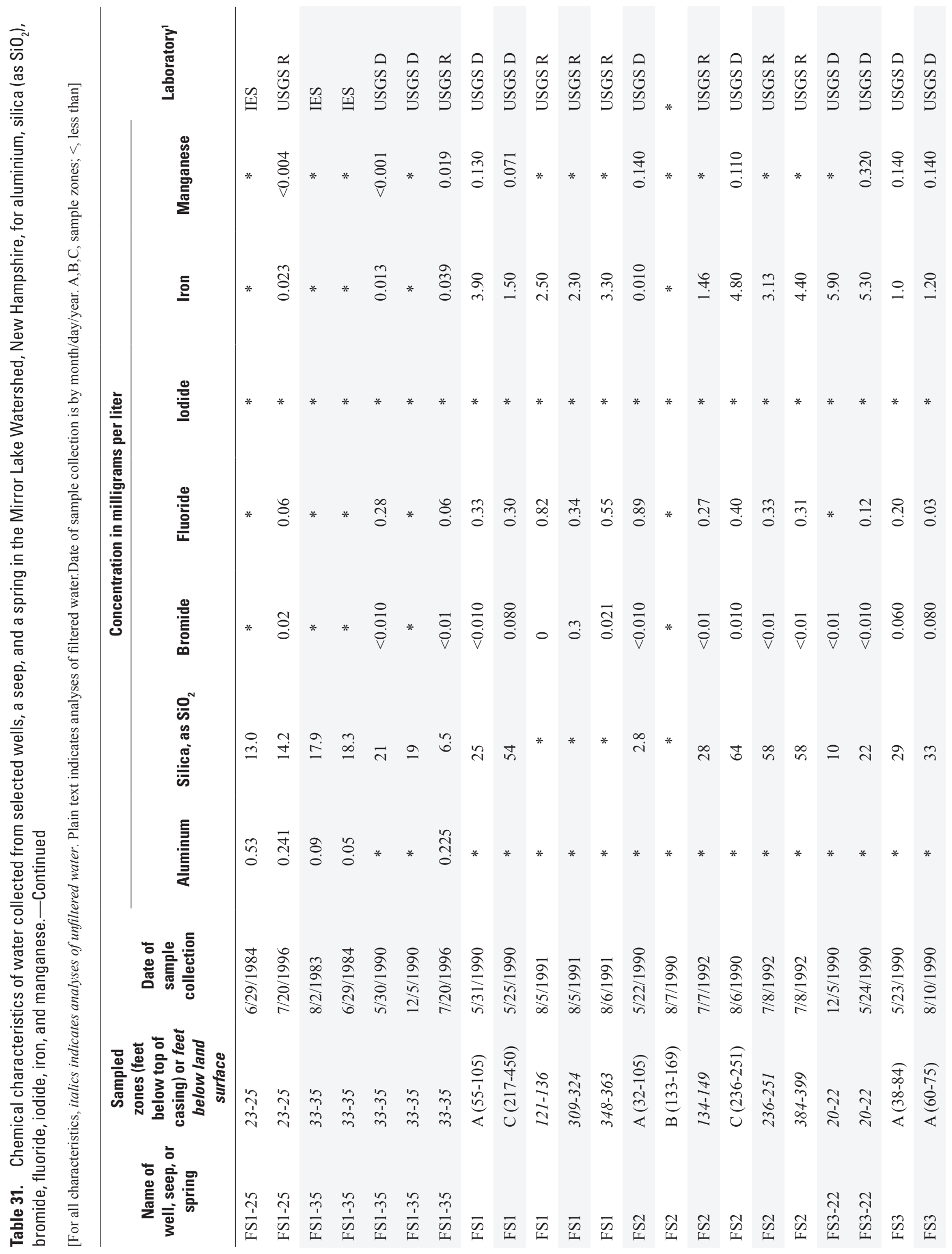




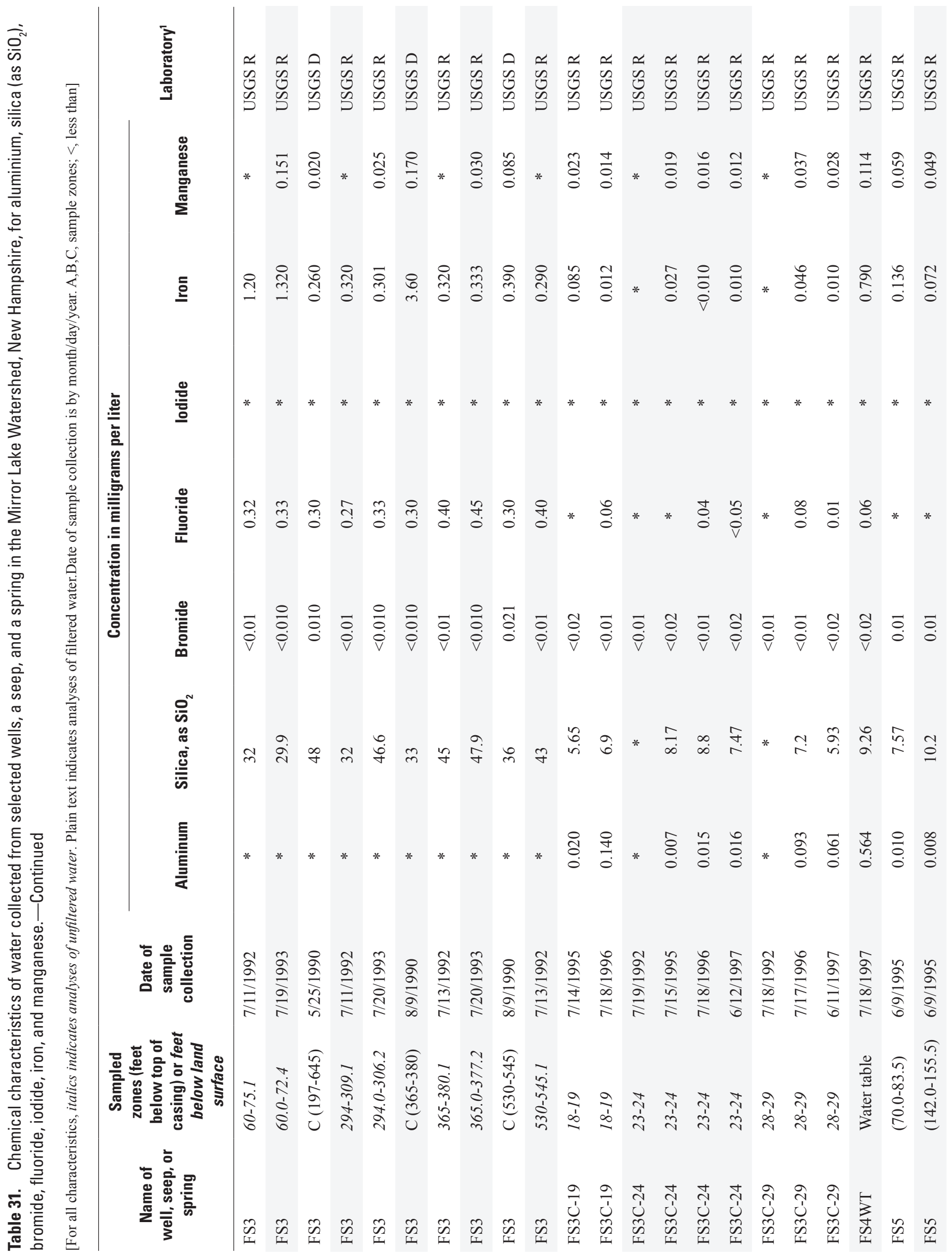




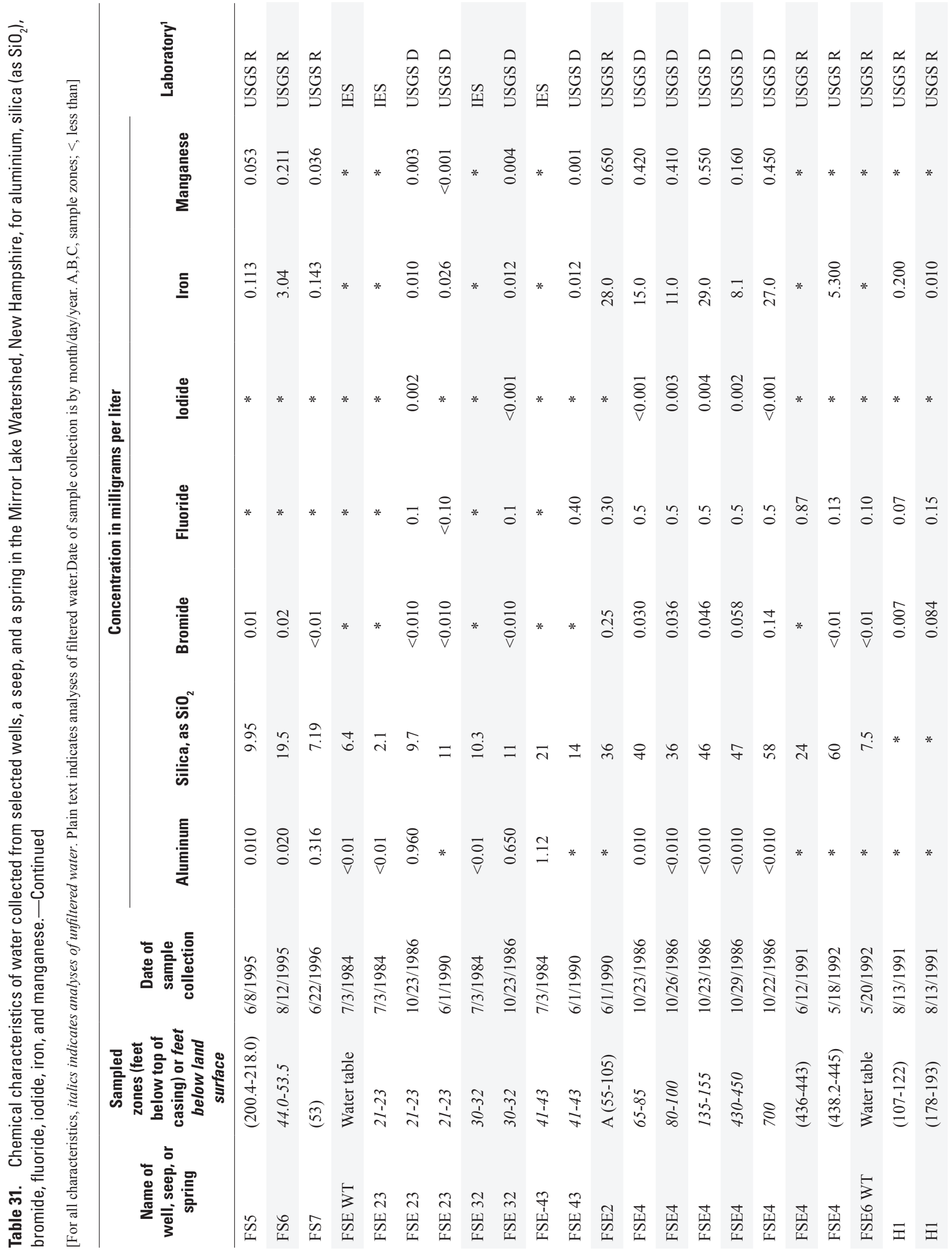


Tables $\quad 91$

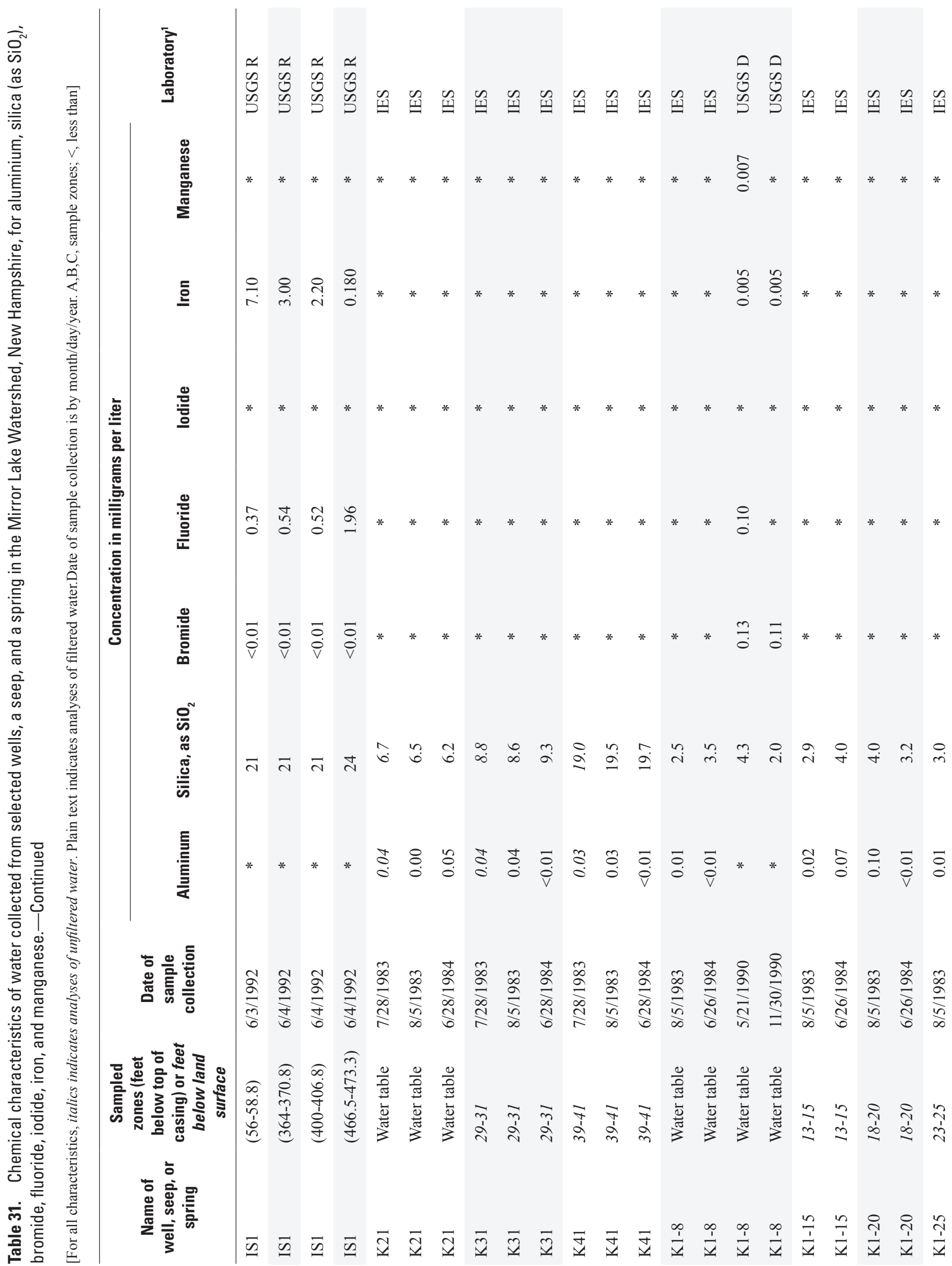




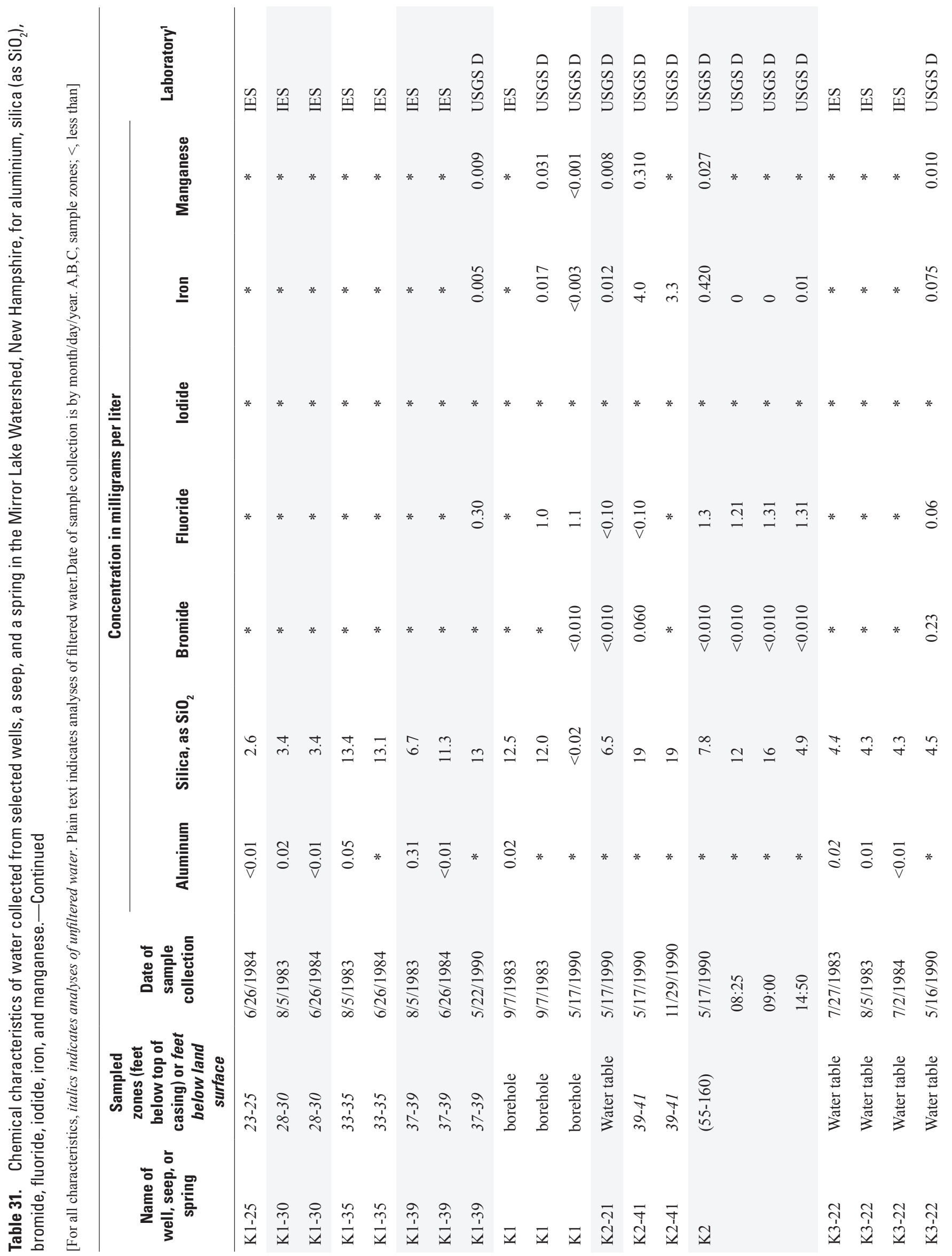




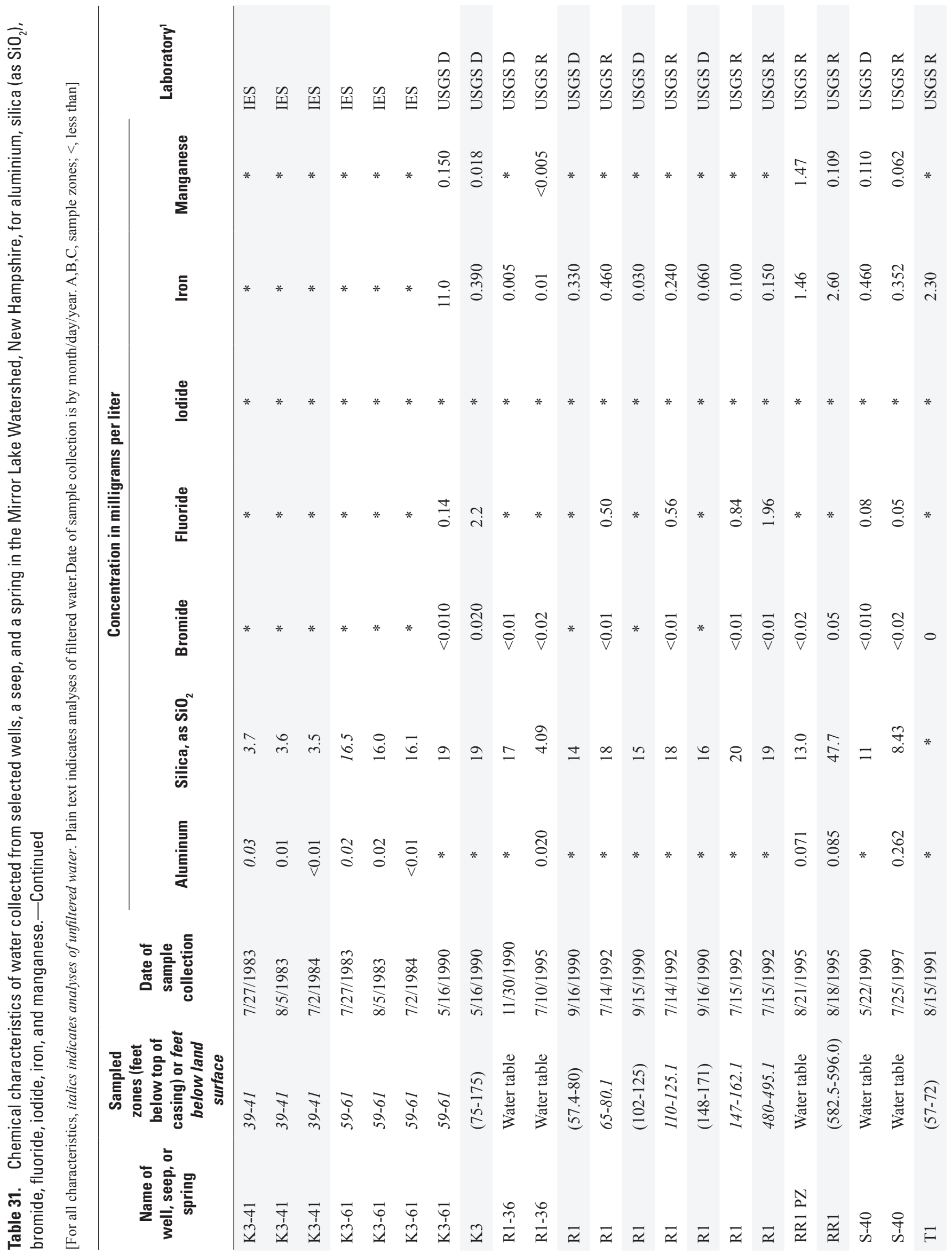




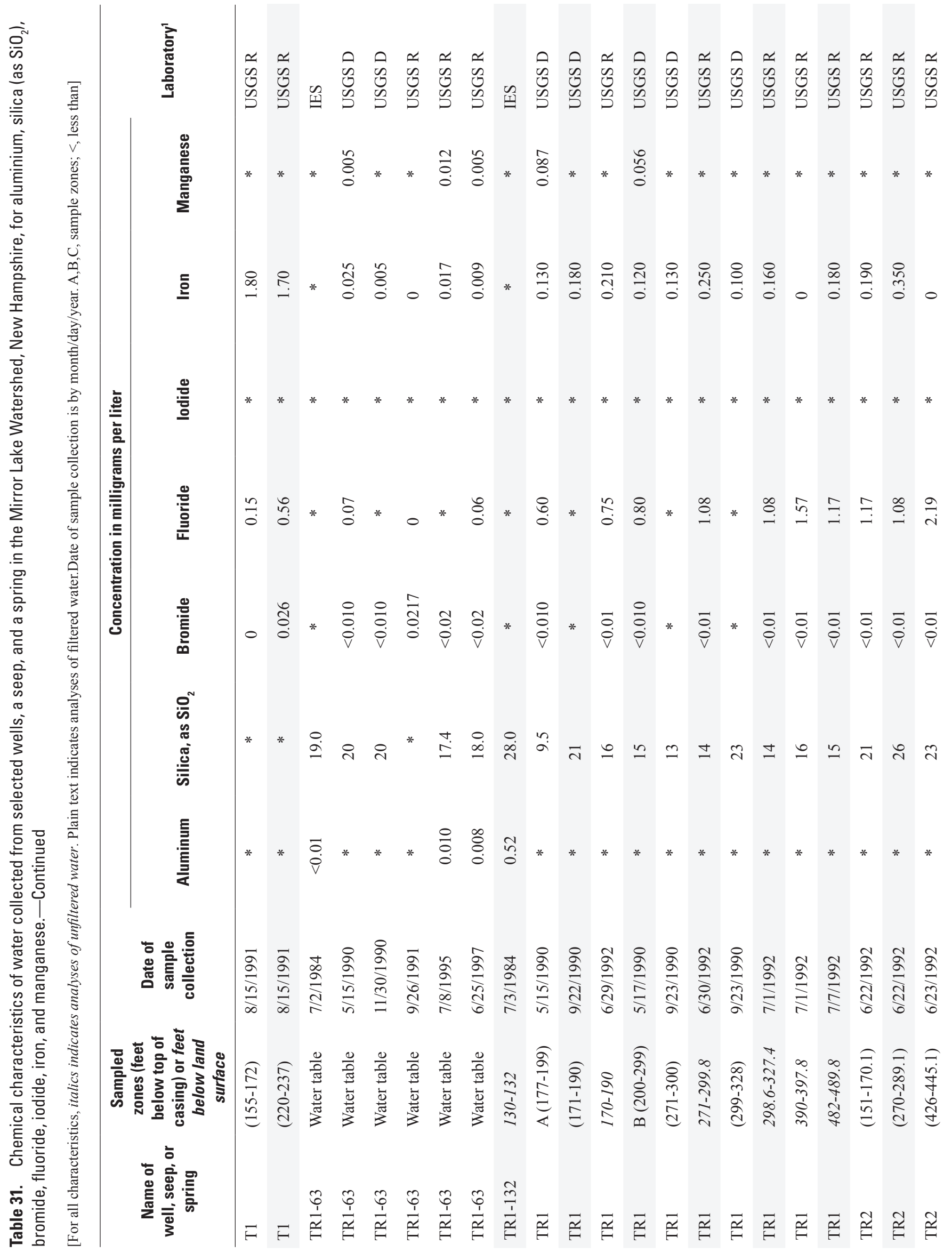




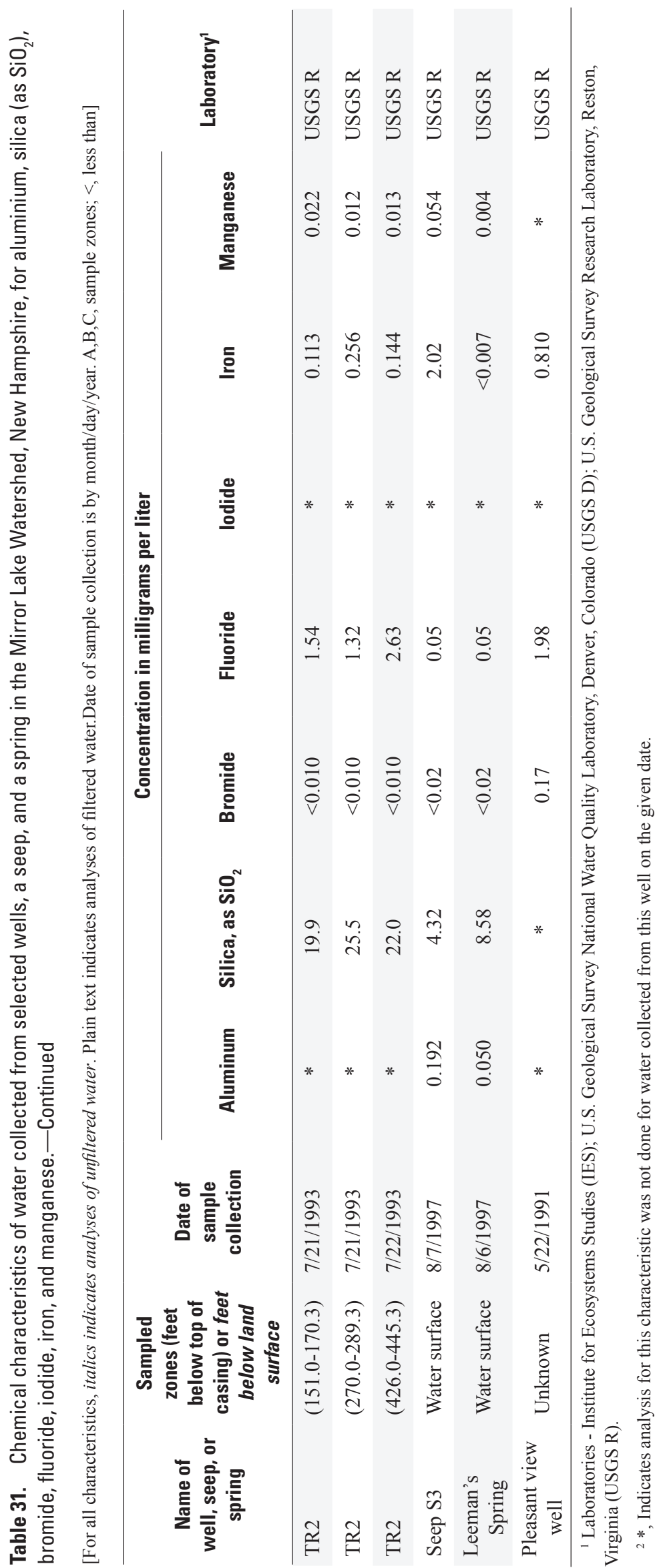



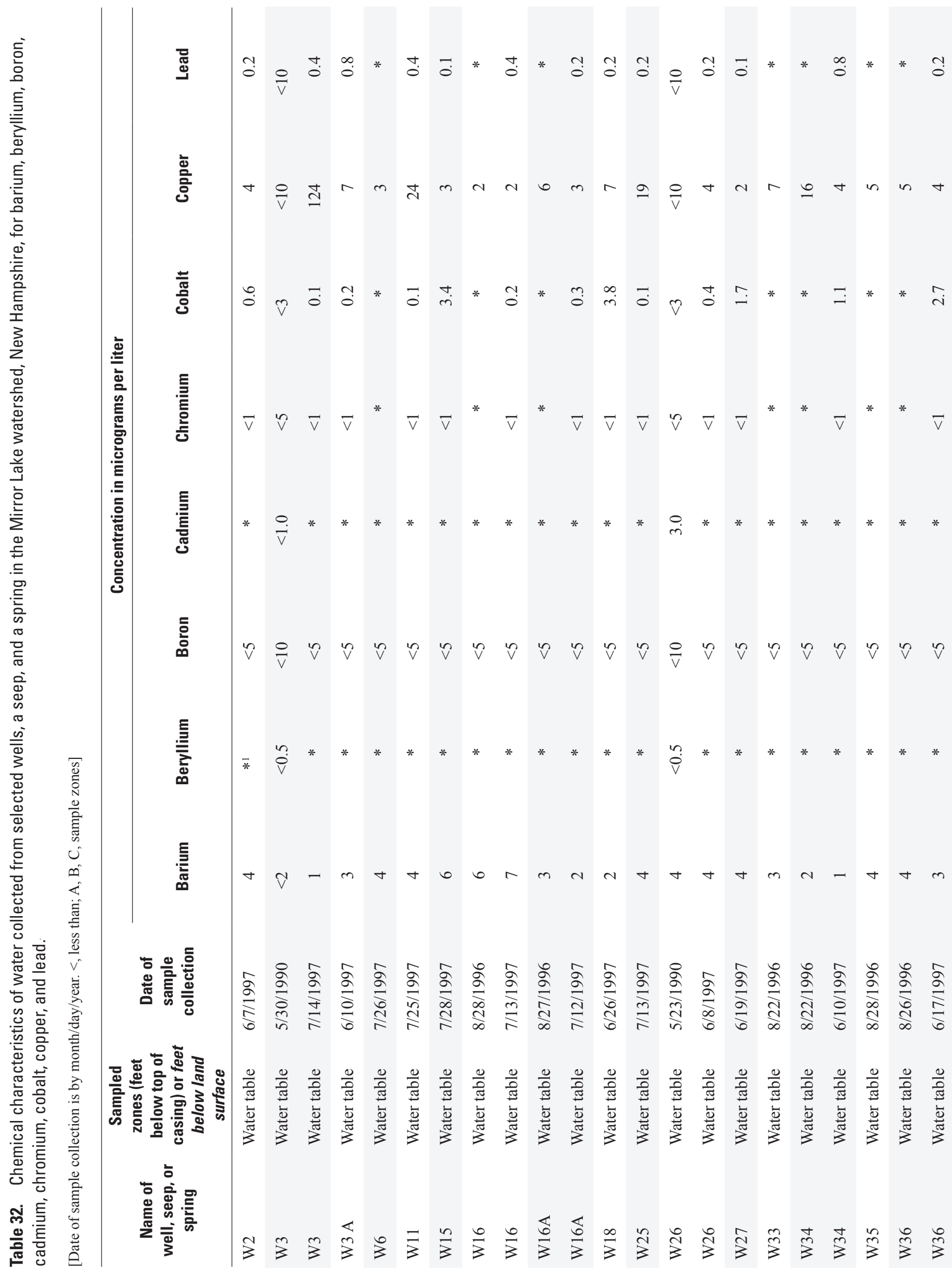
Tables $\quad 97$

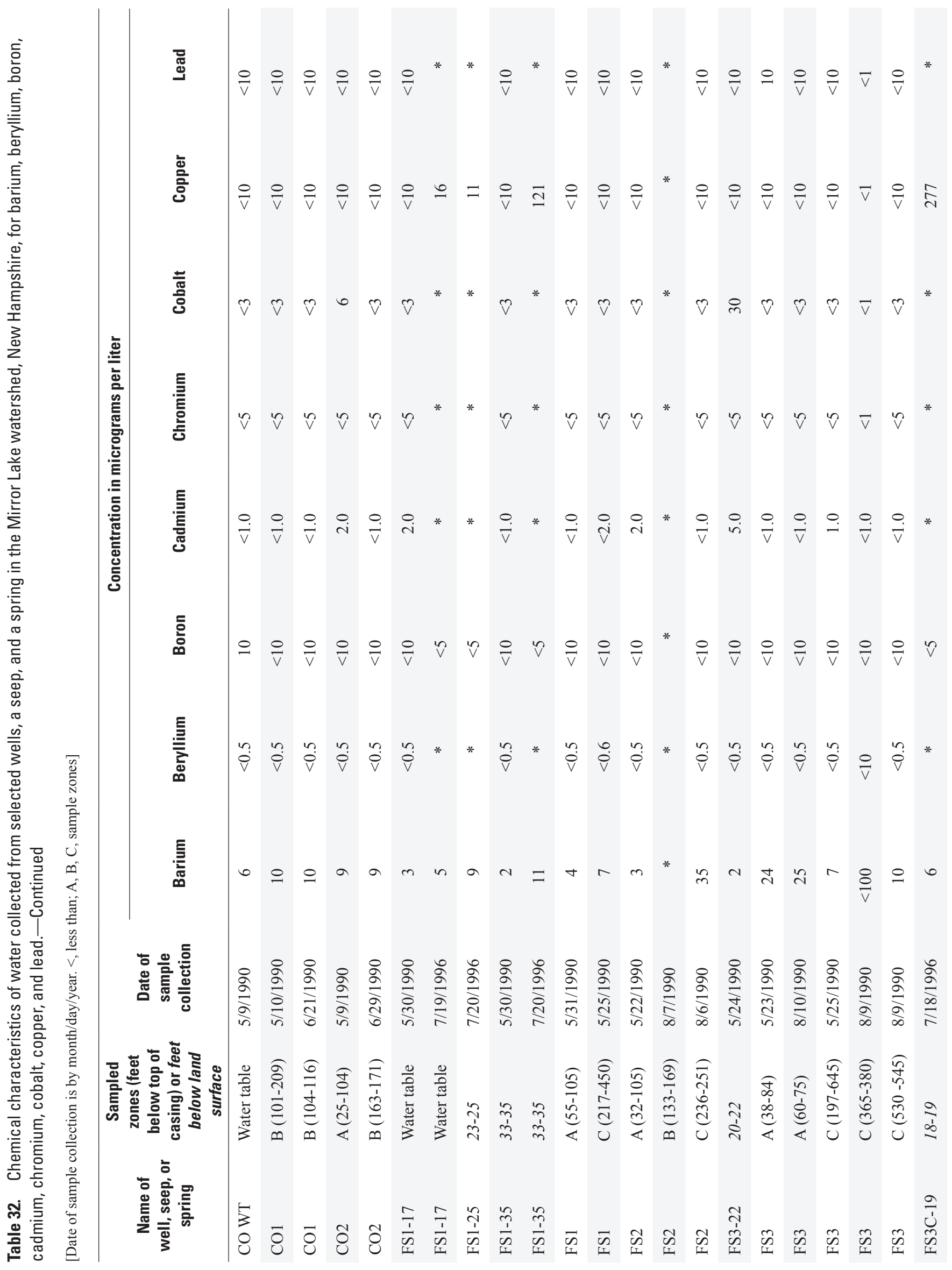



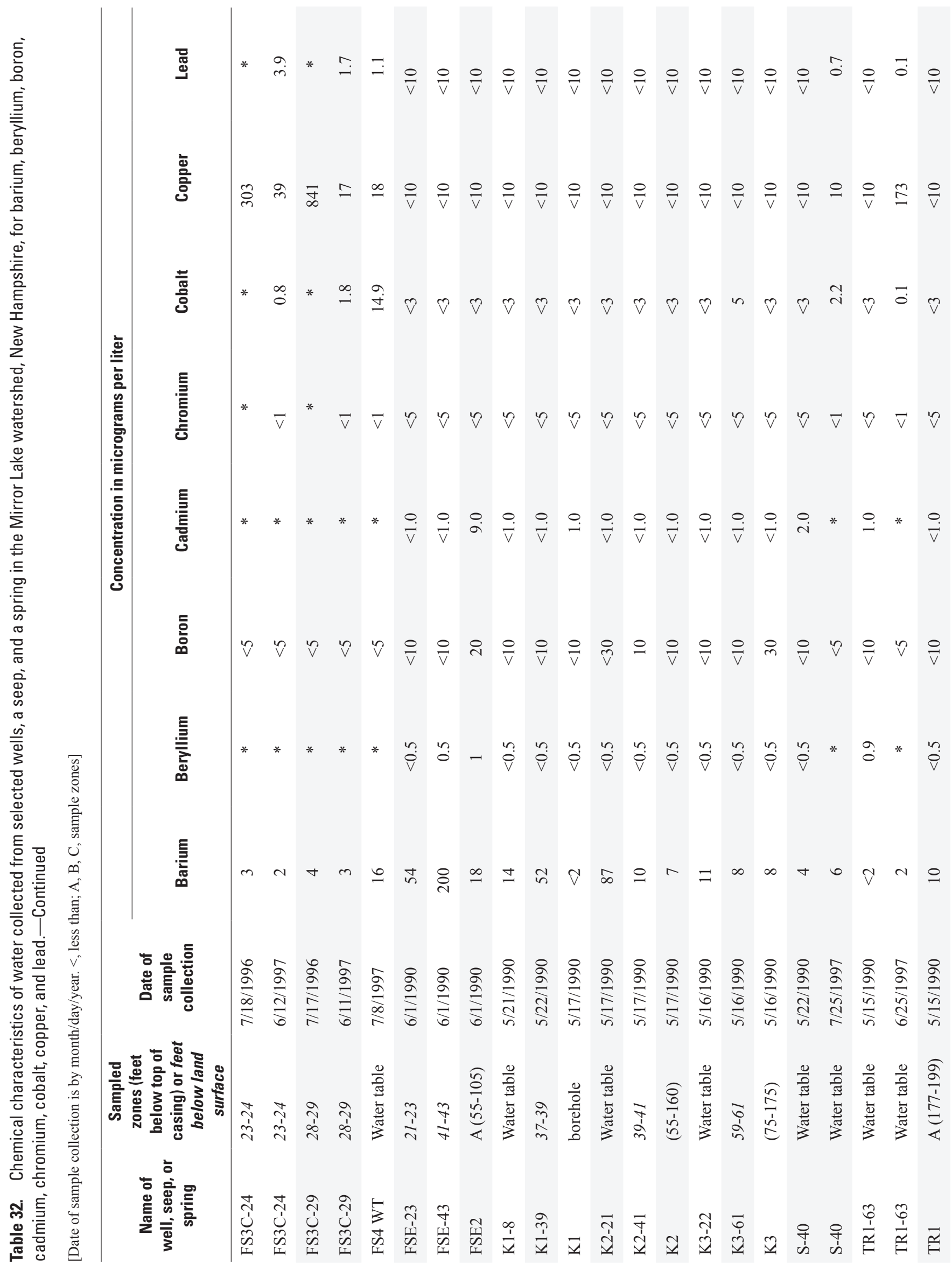


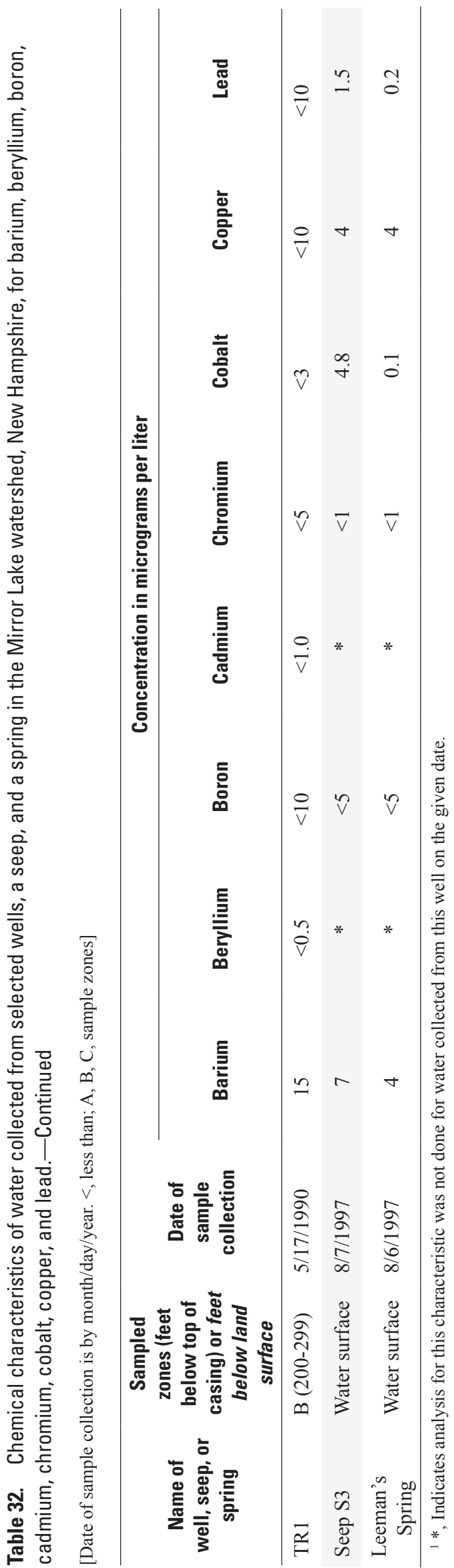



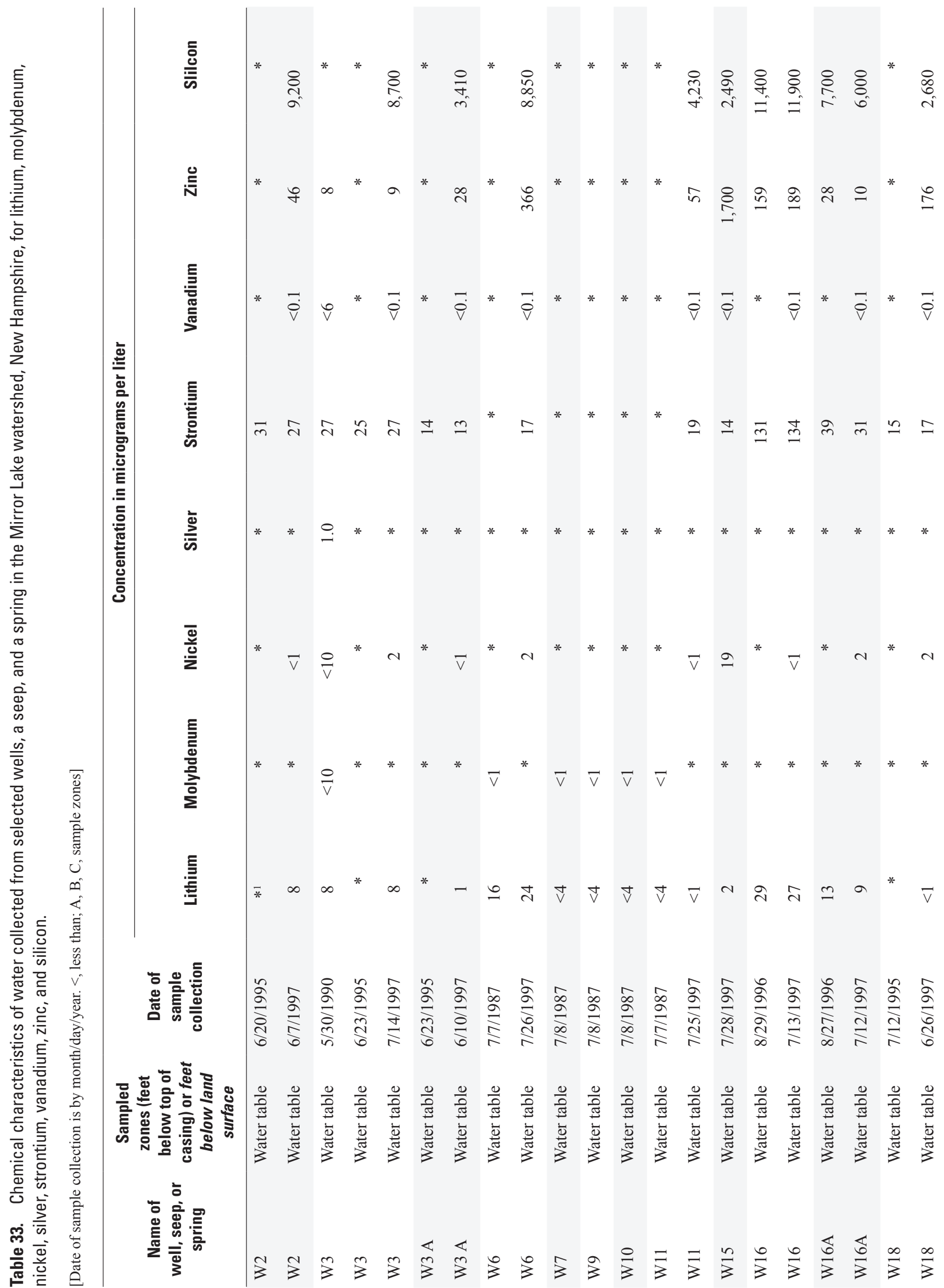
Tables 101
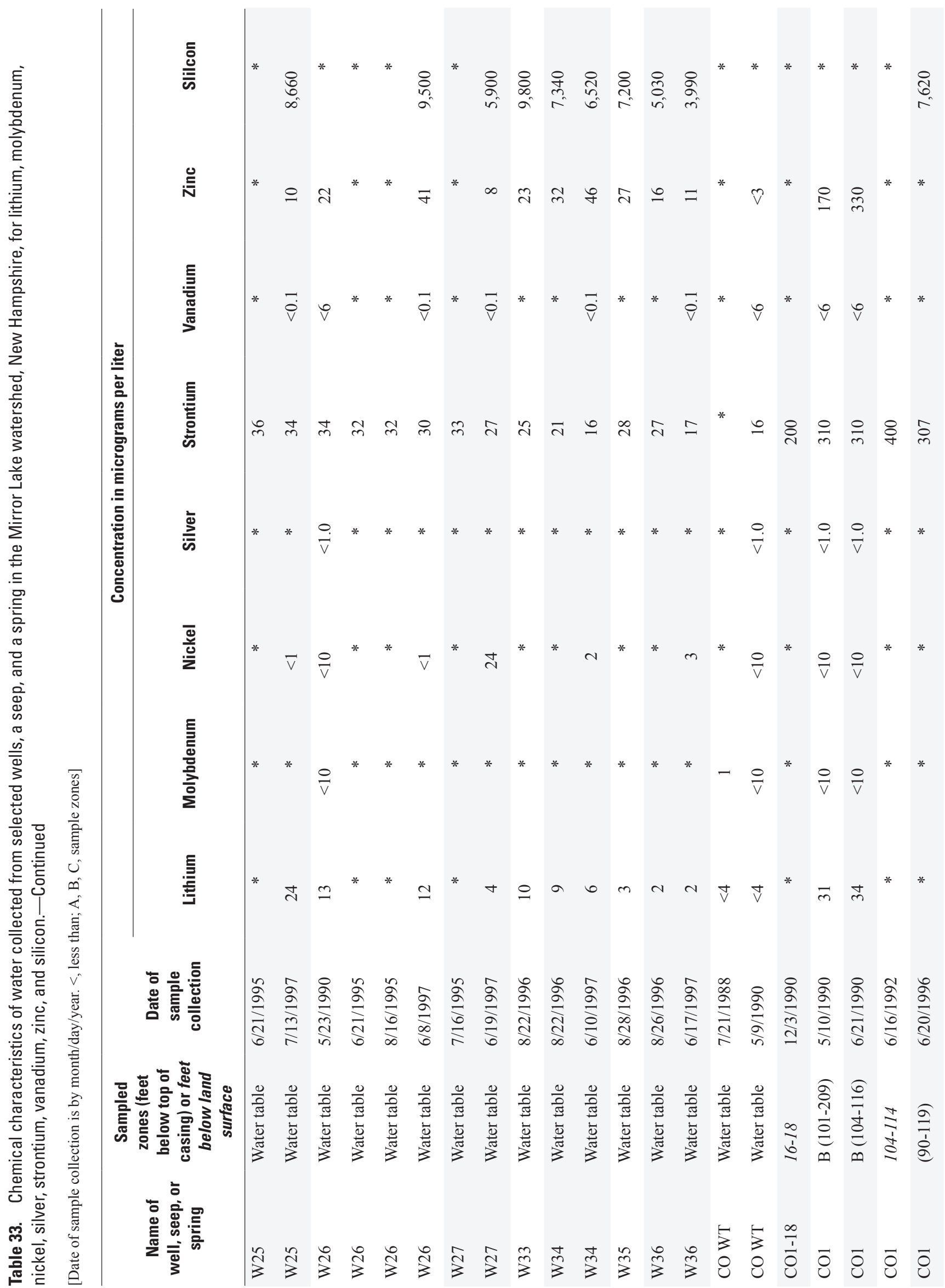

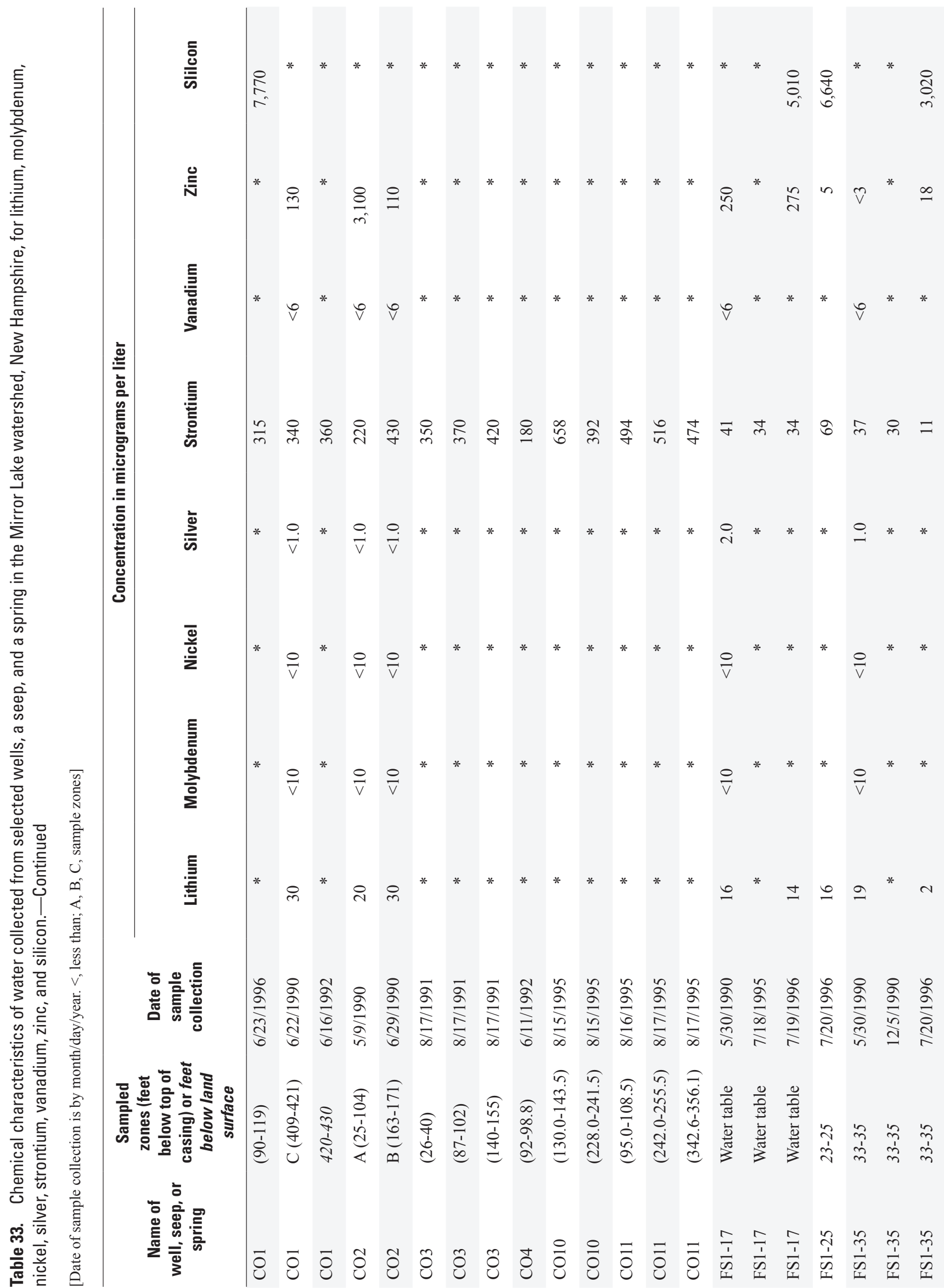

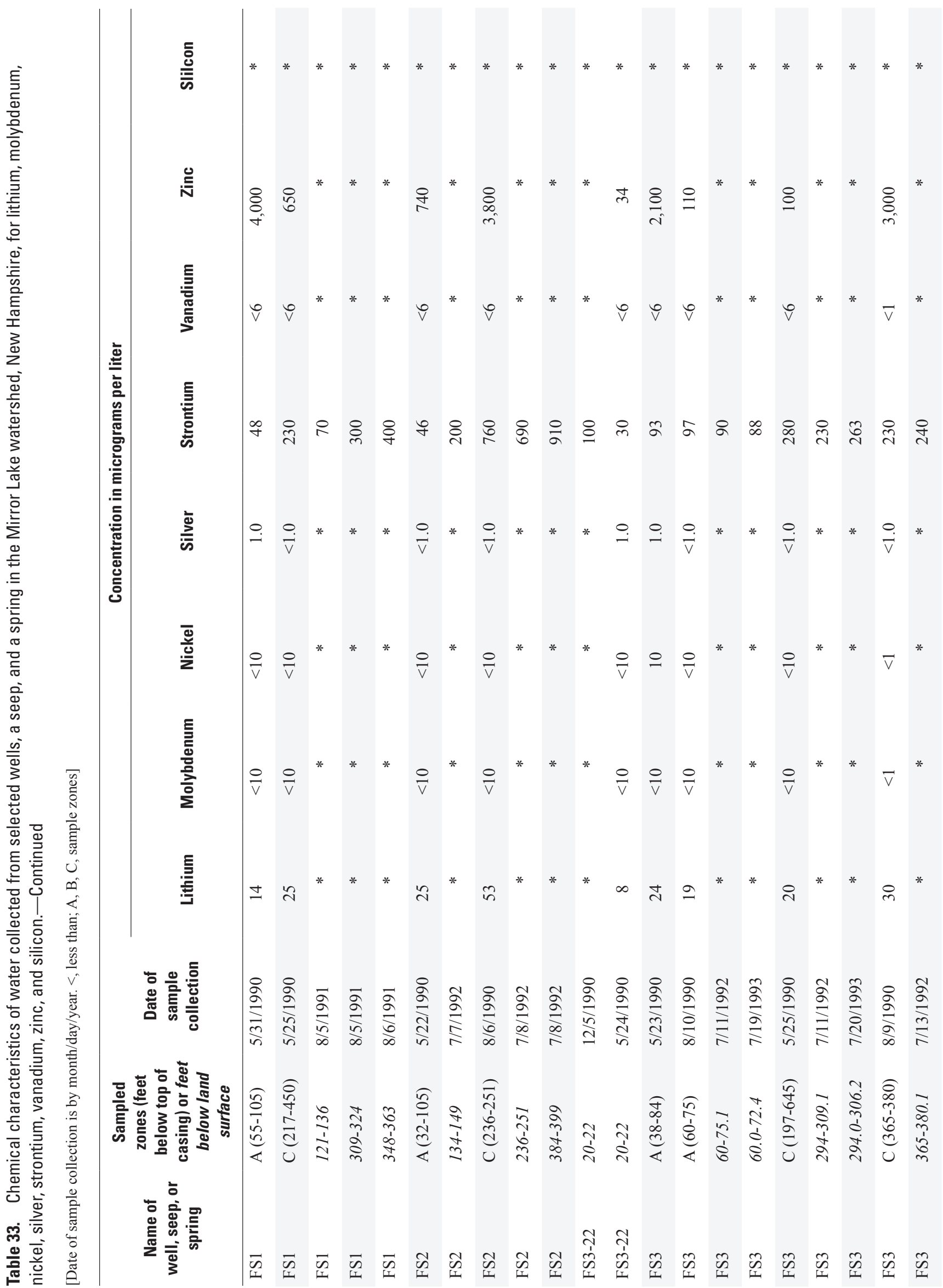

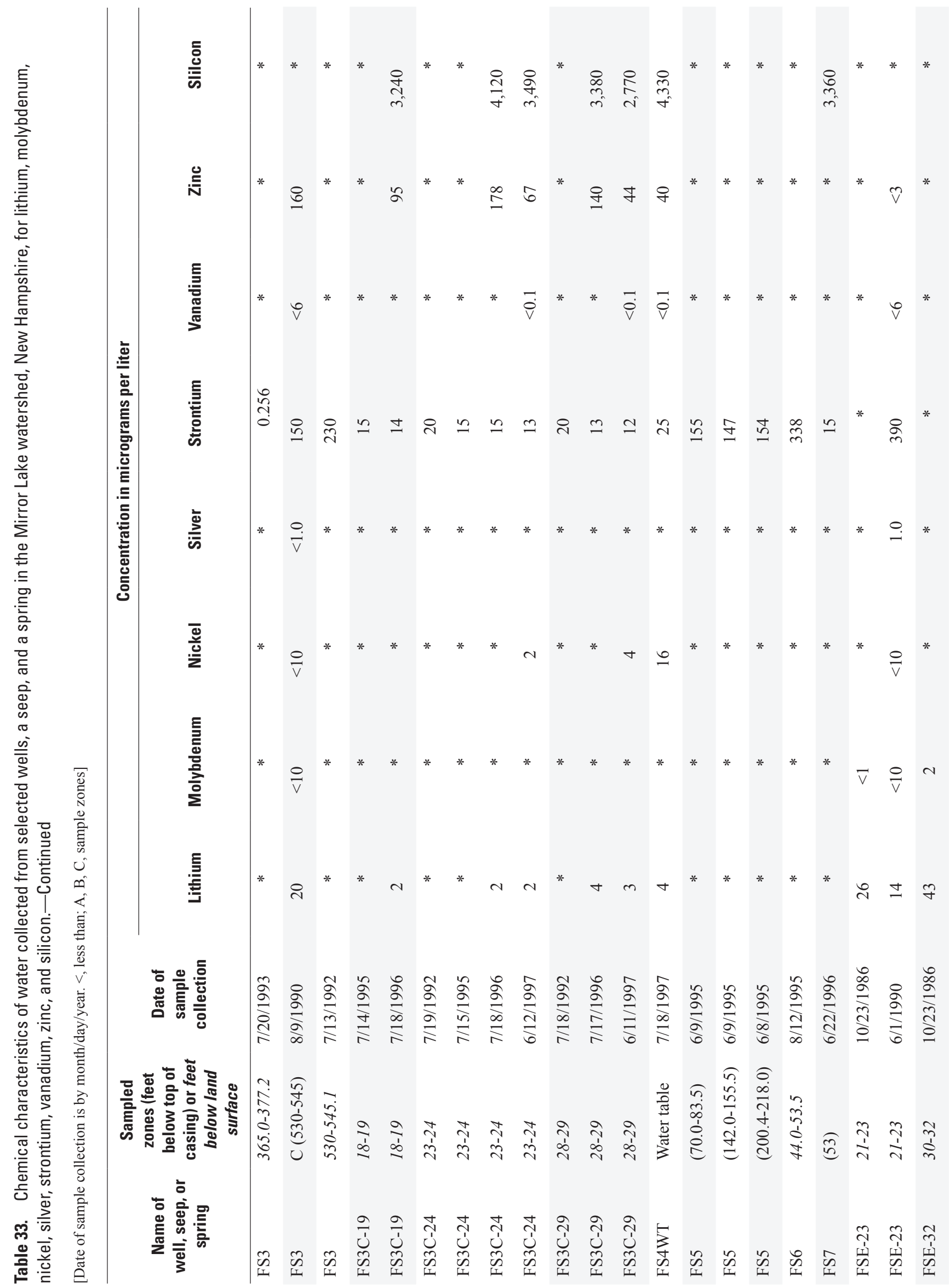

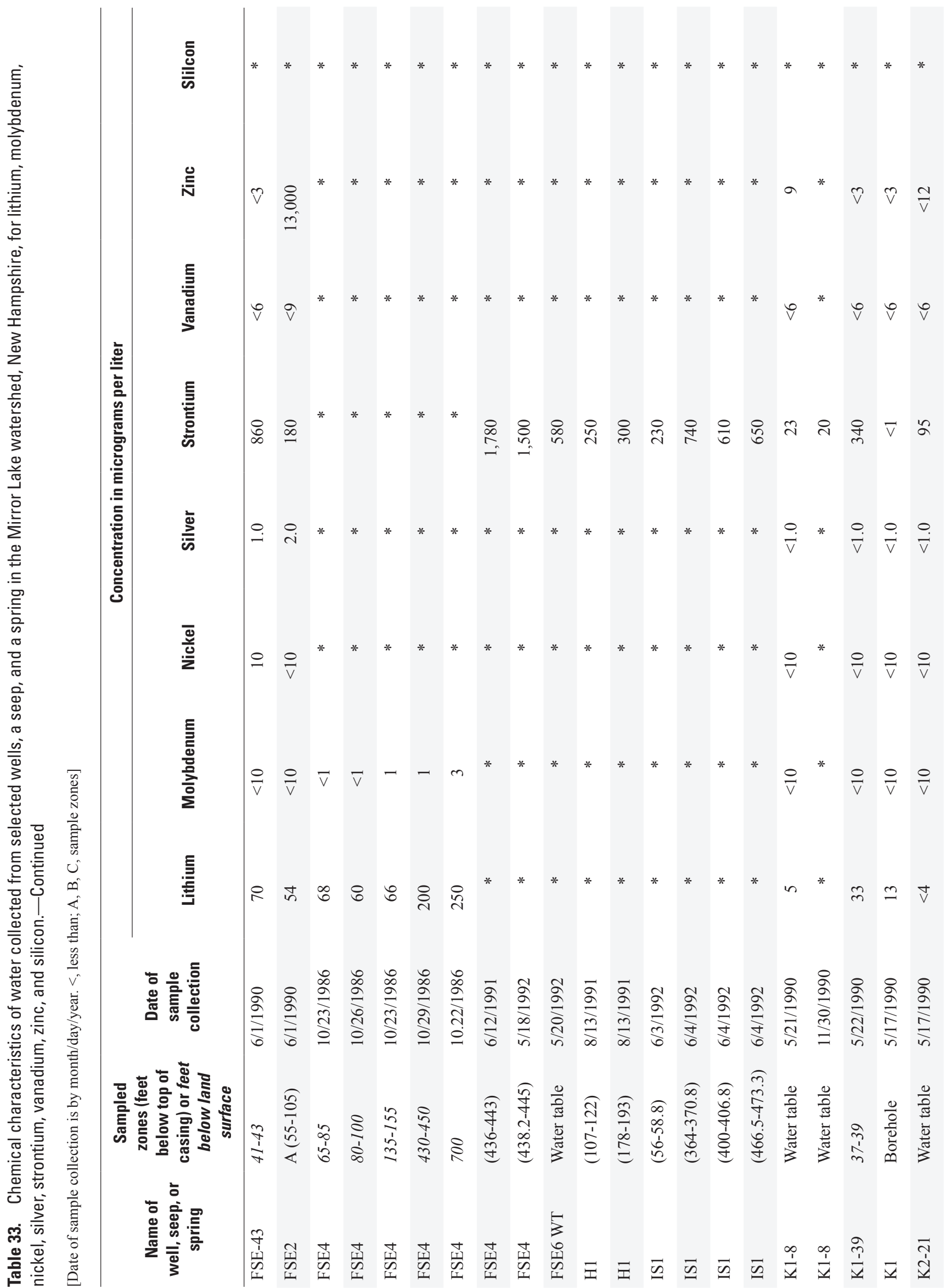


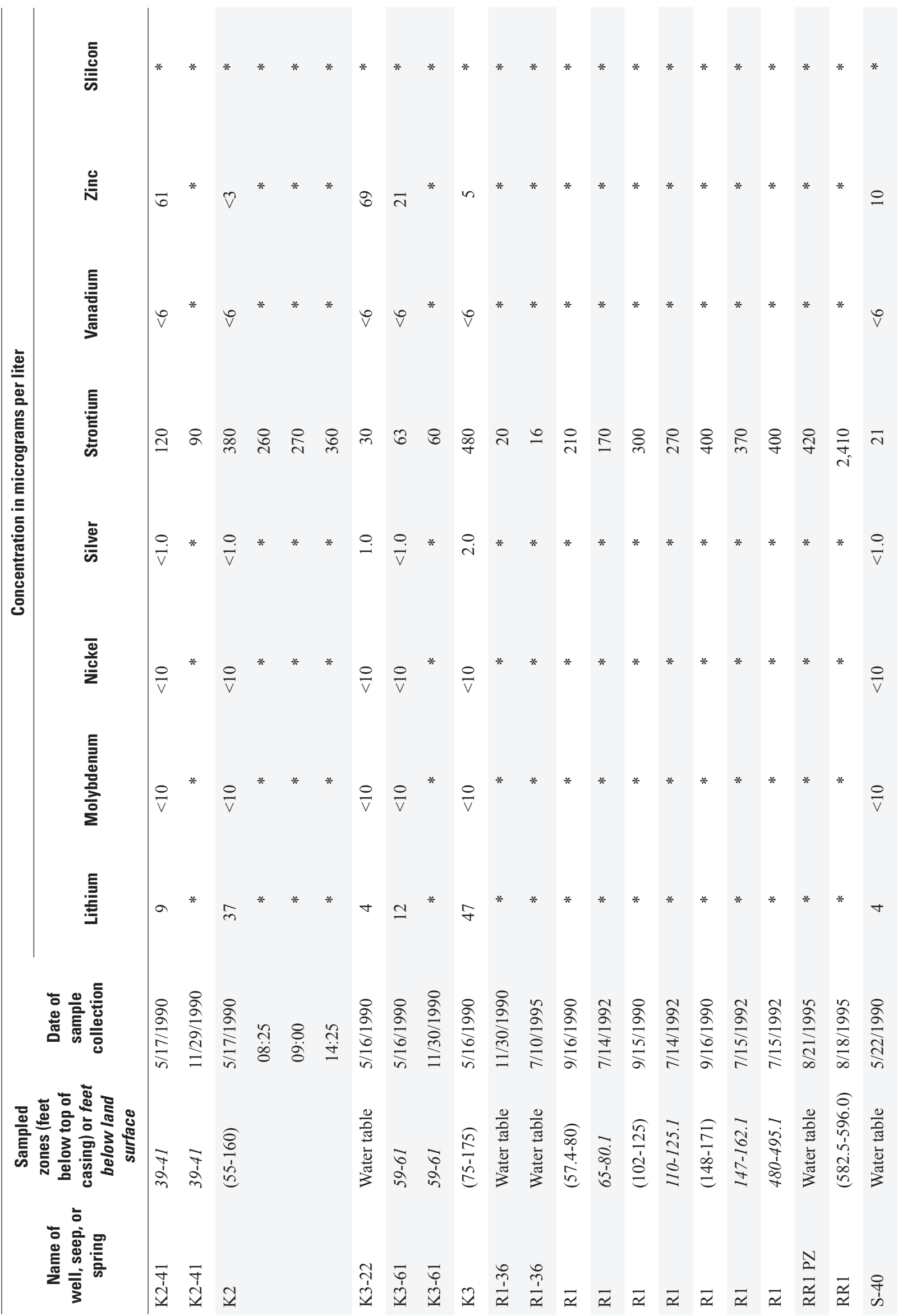


Tables 107

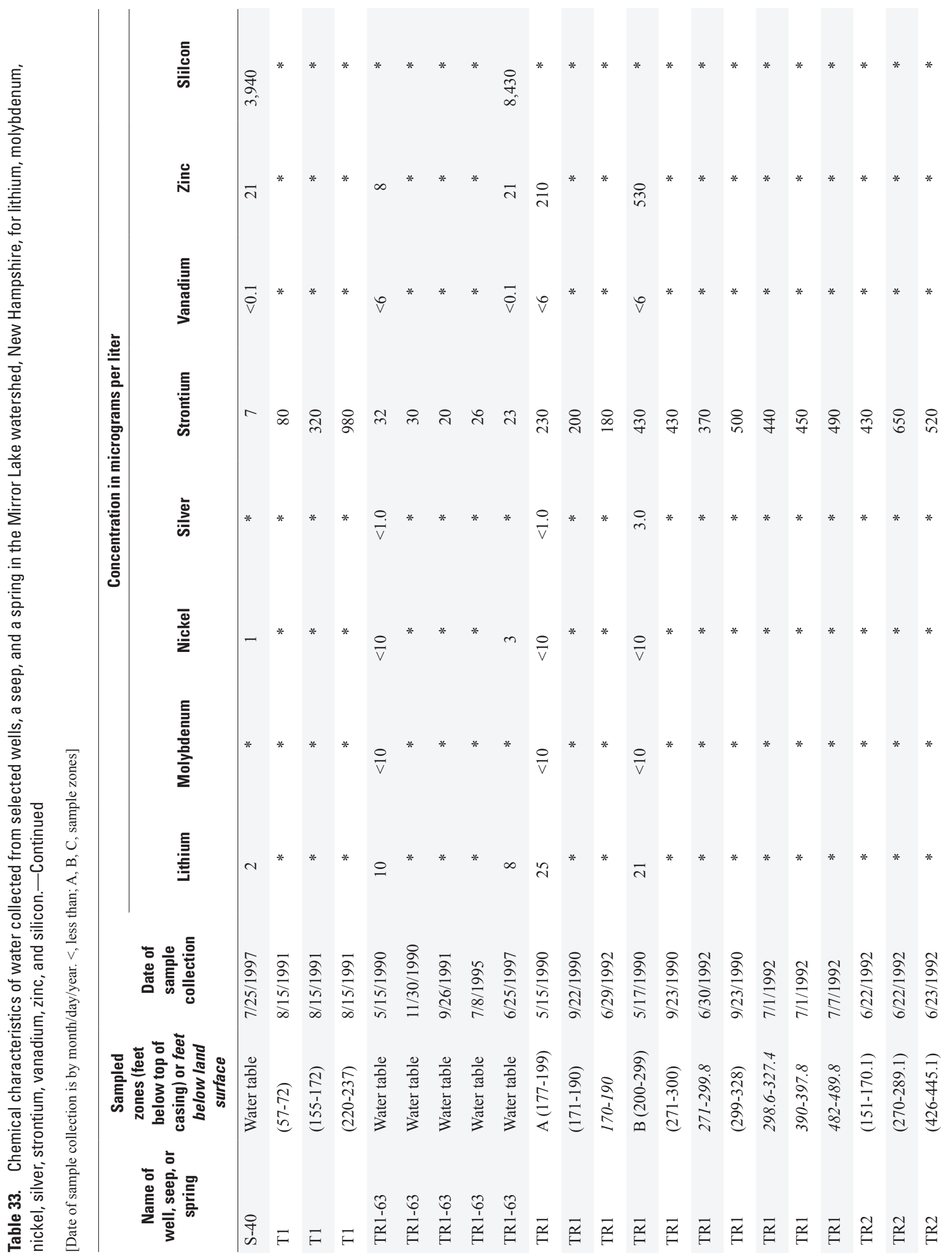




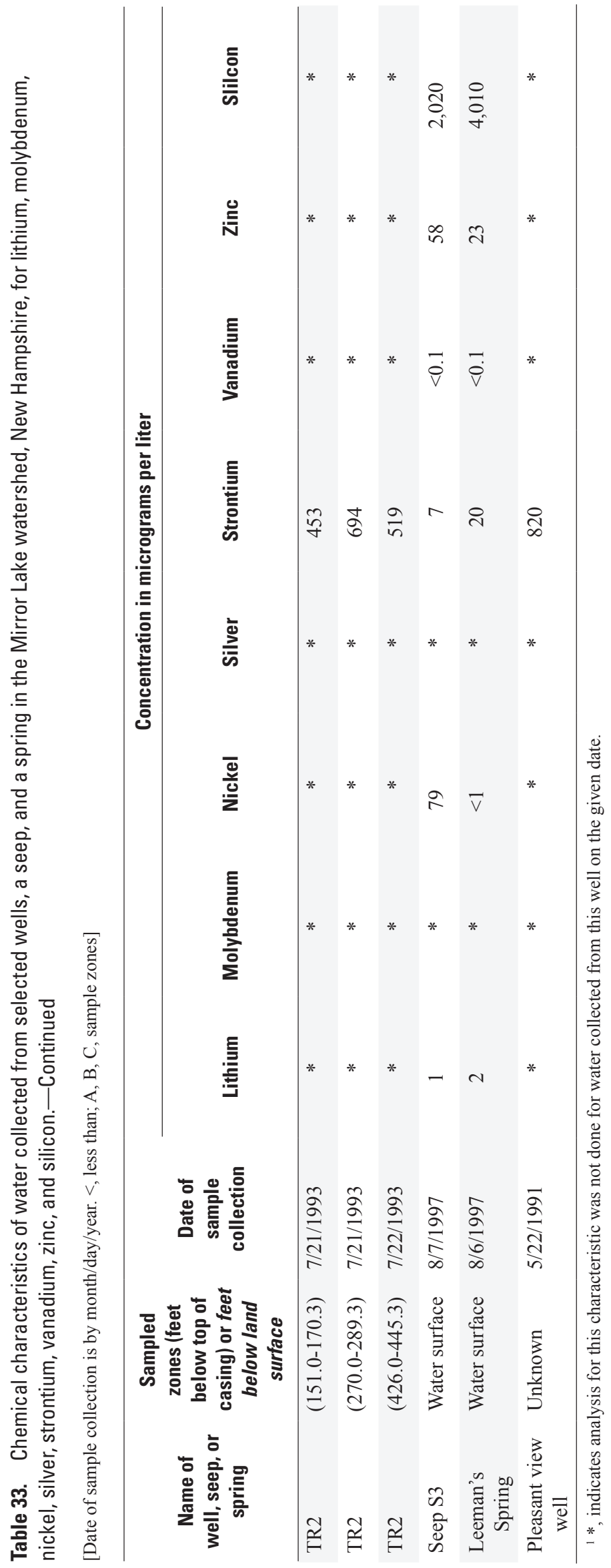




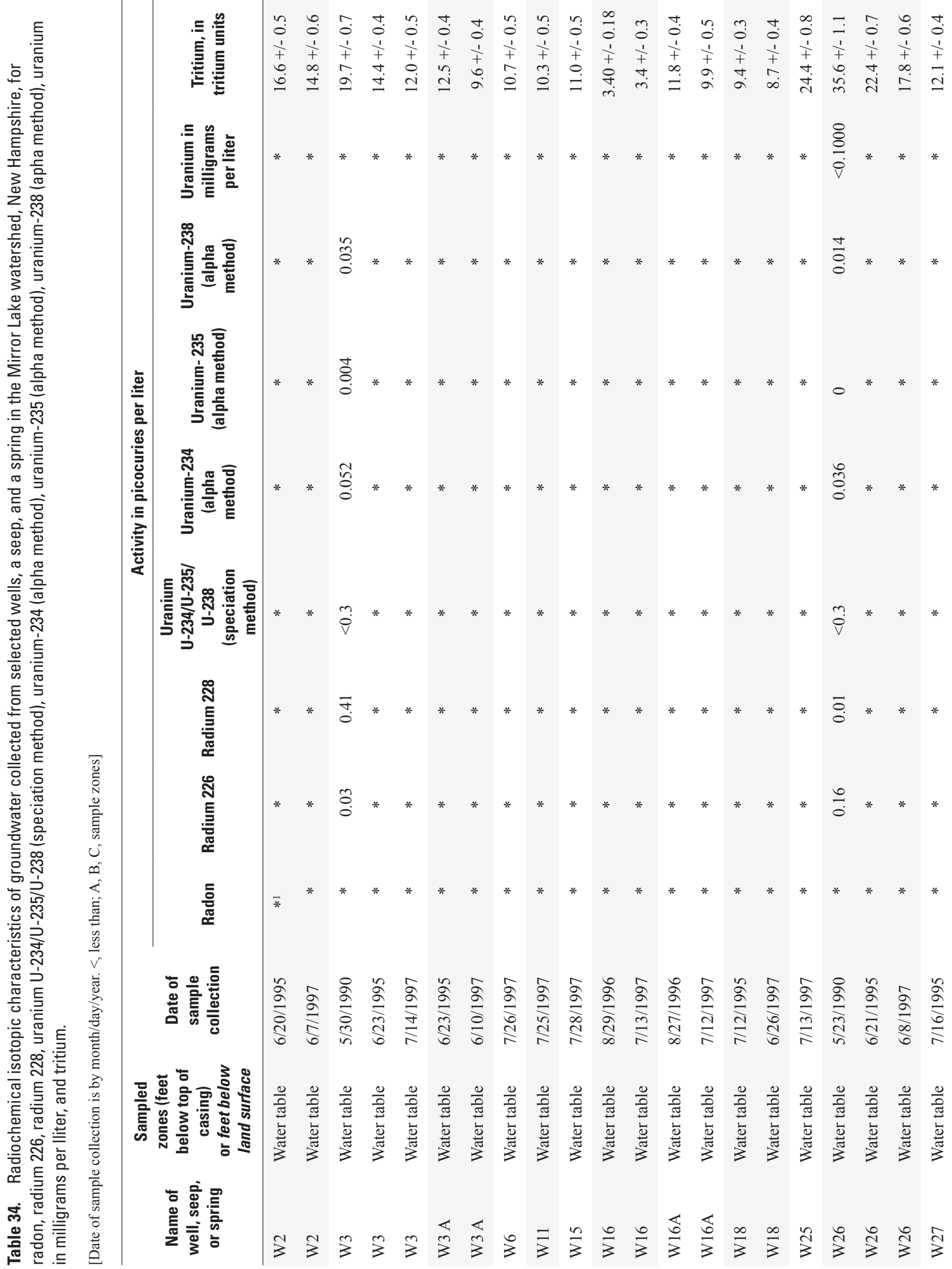




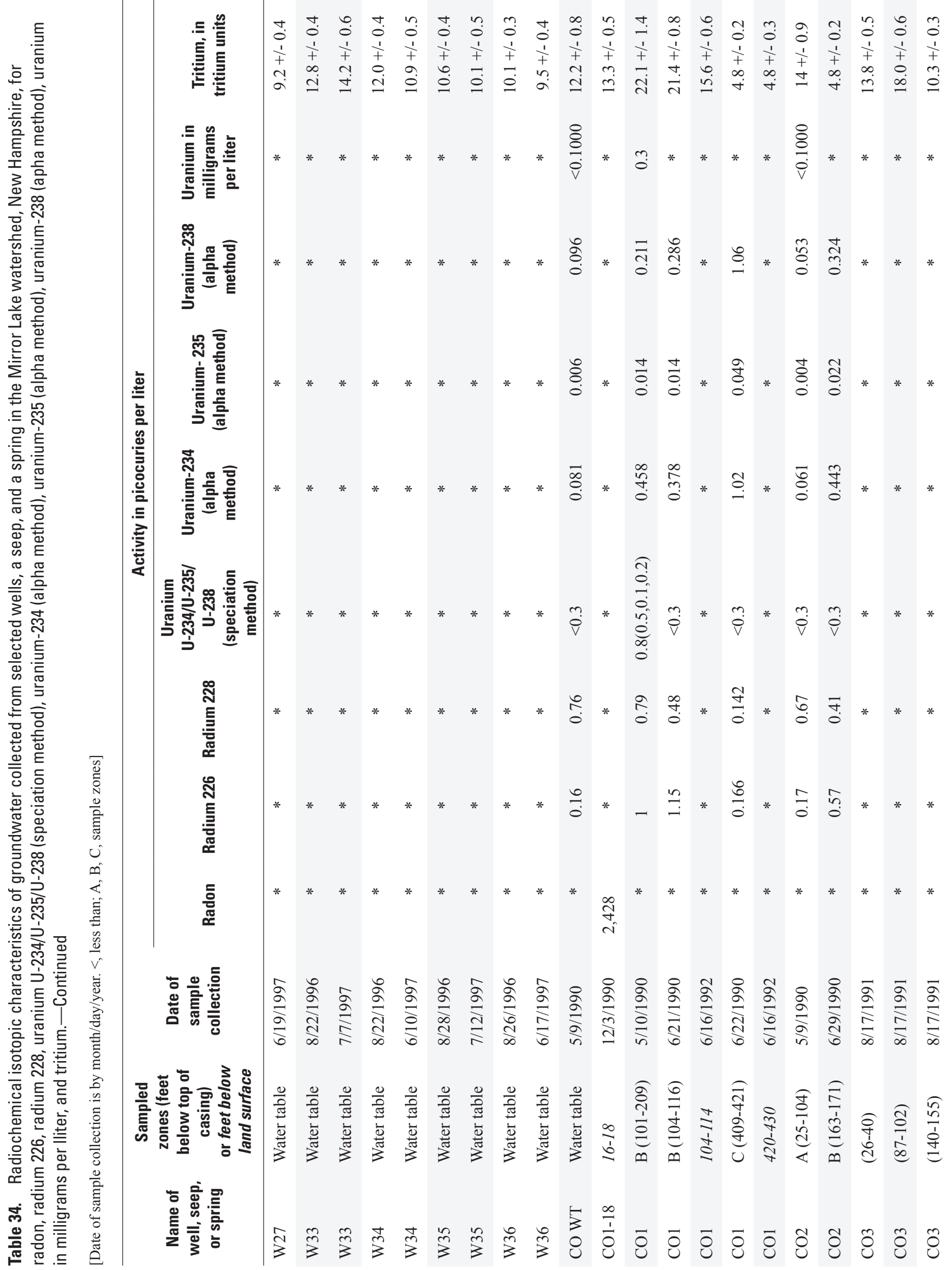



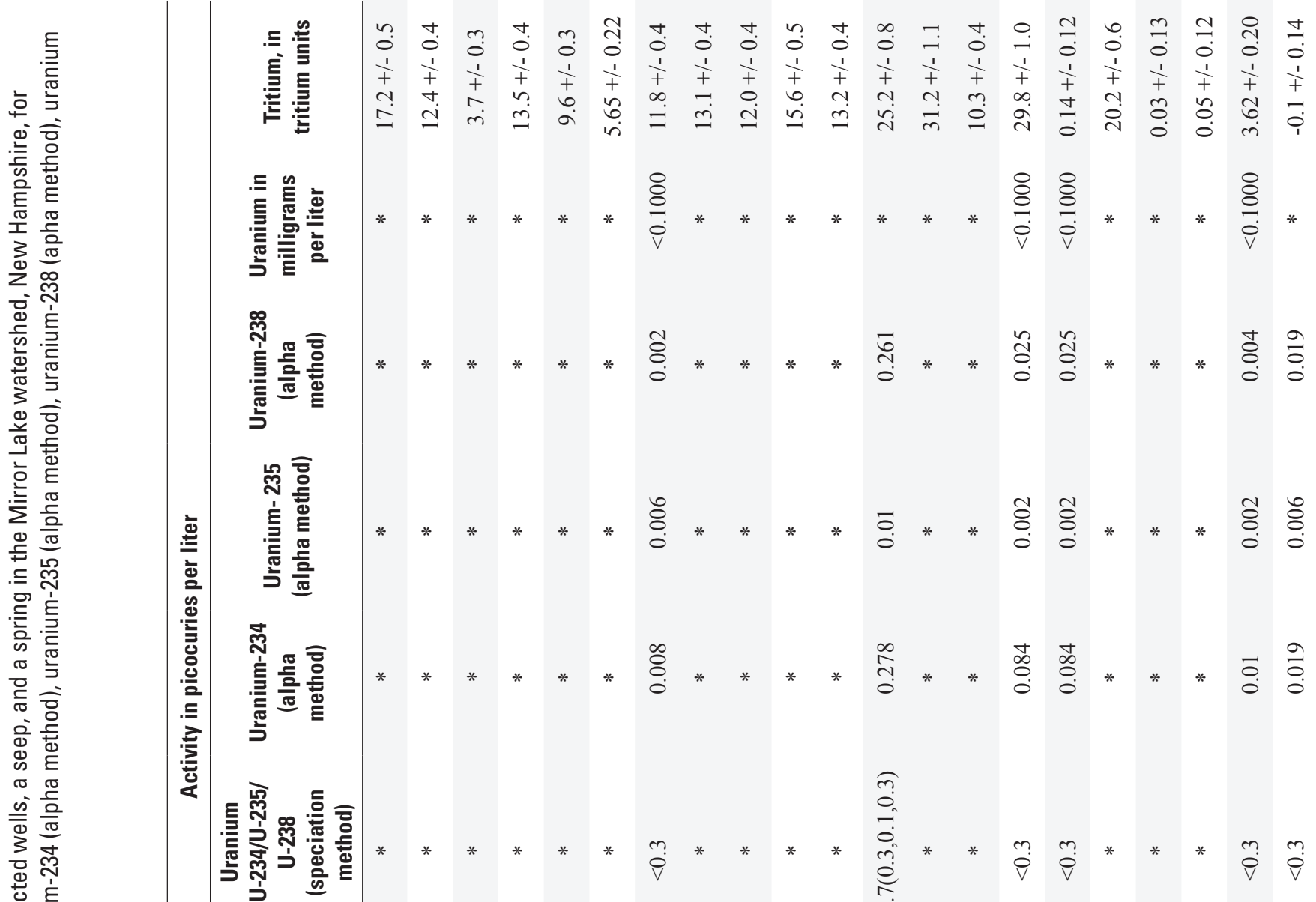

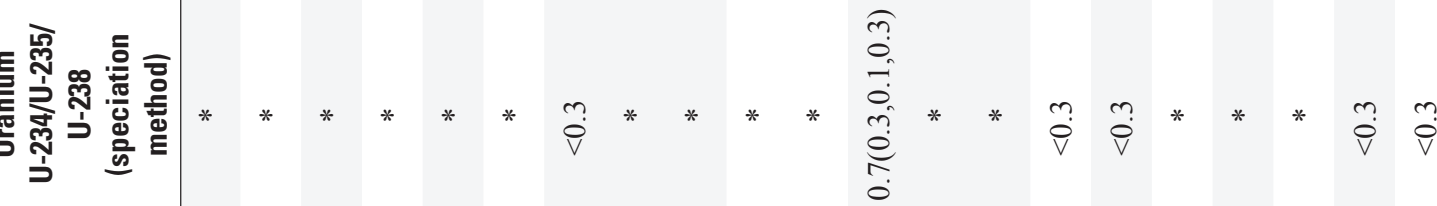

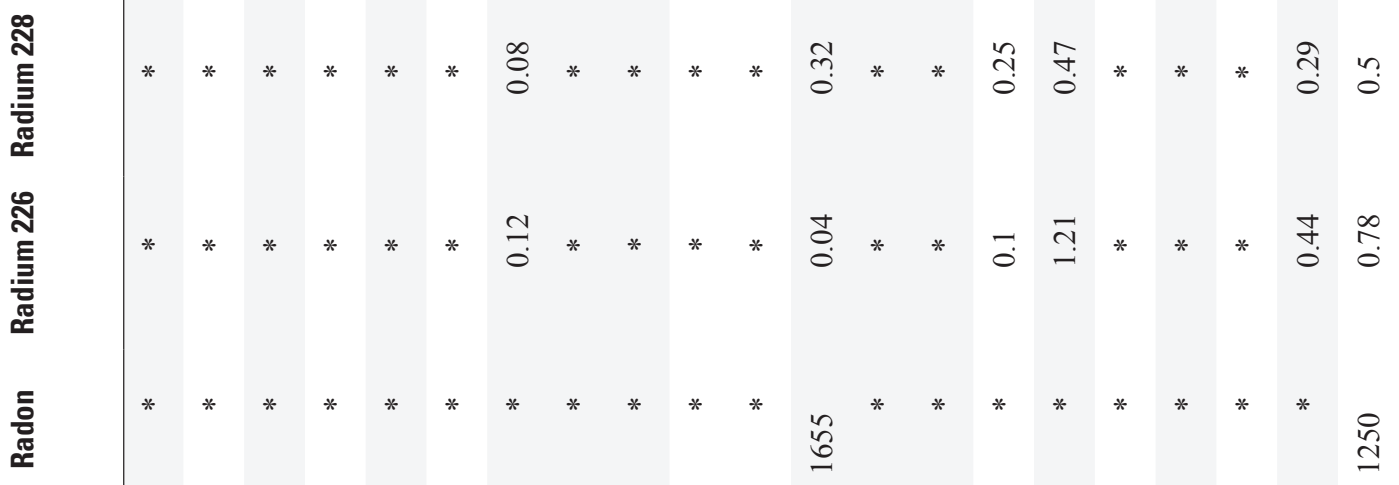

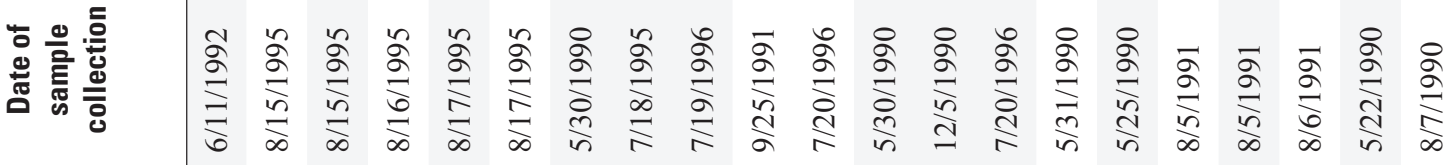

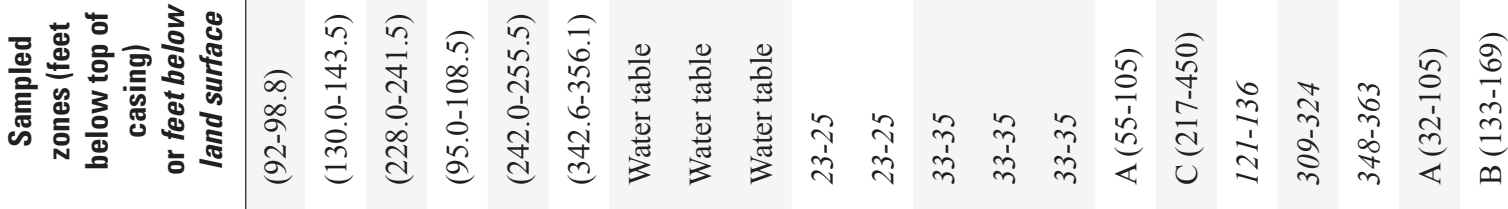

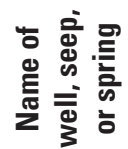



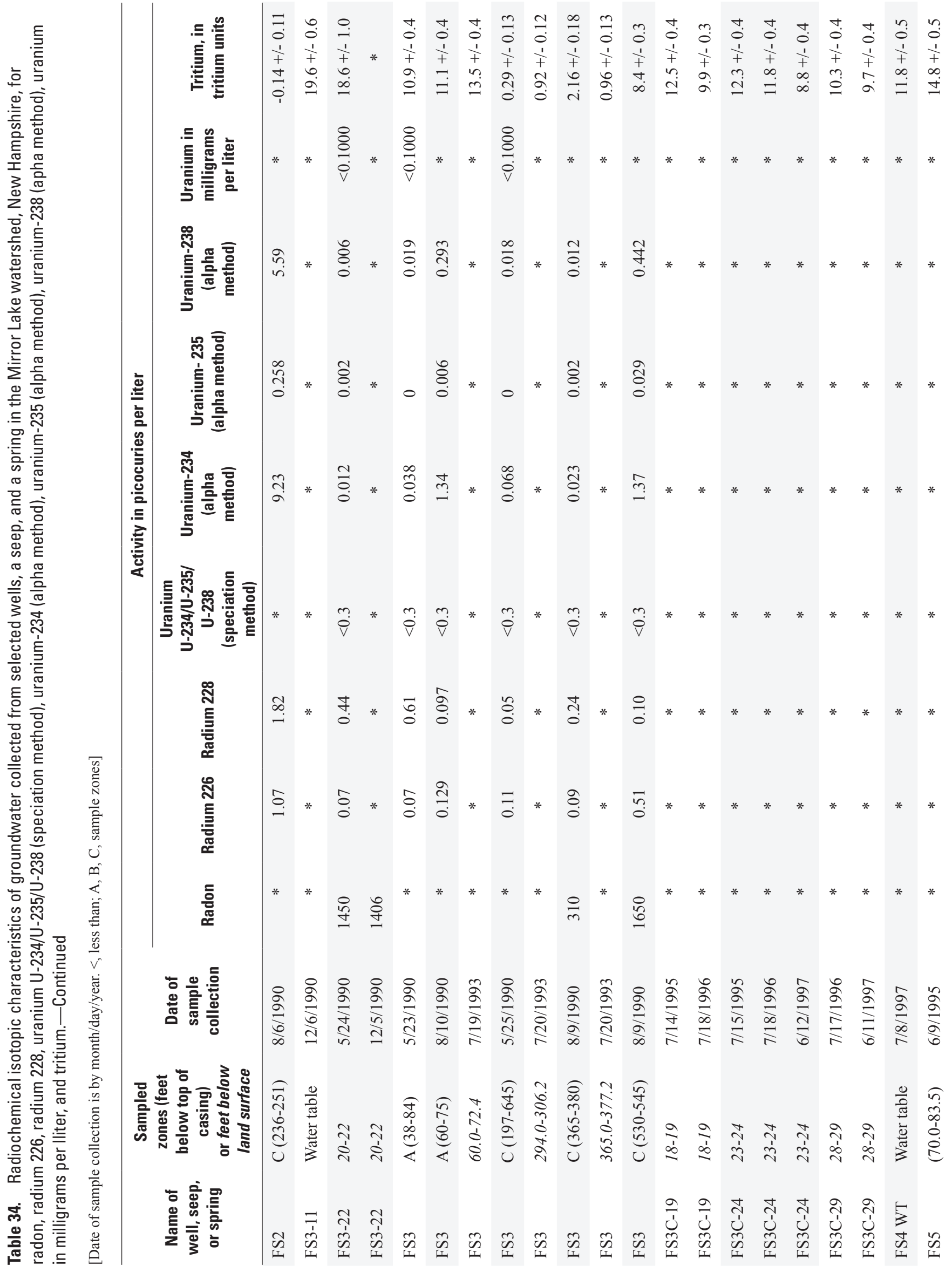

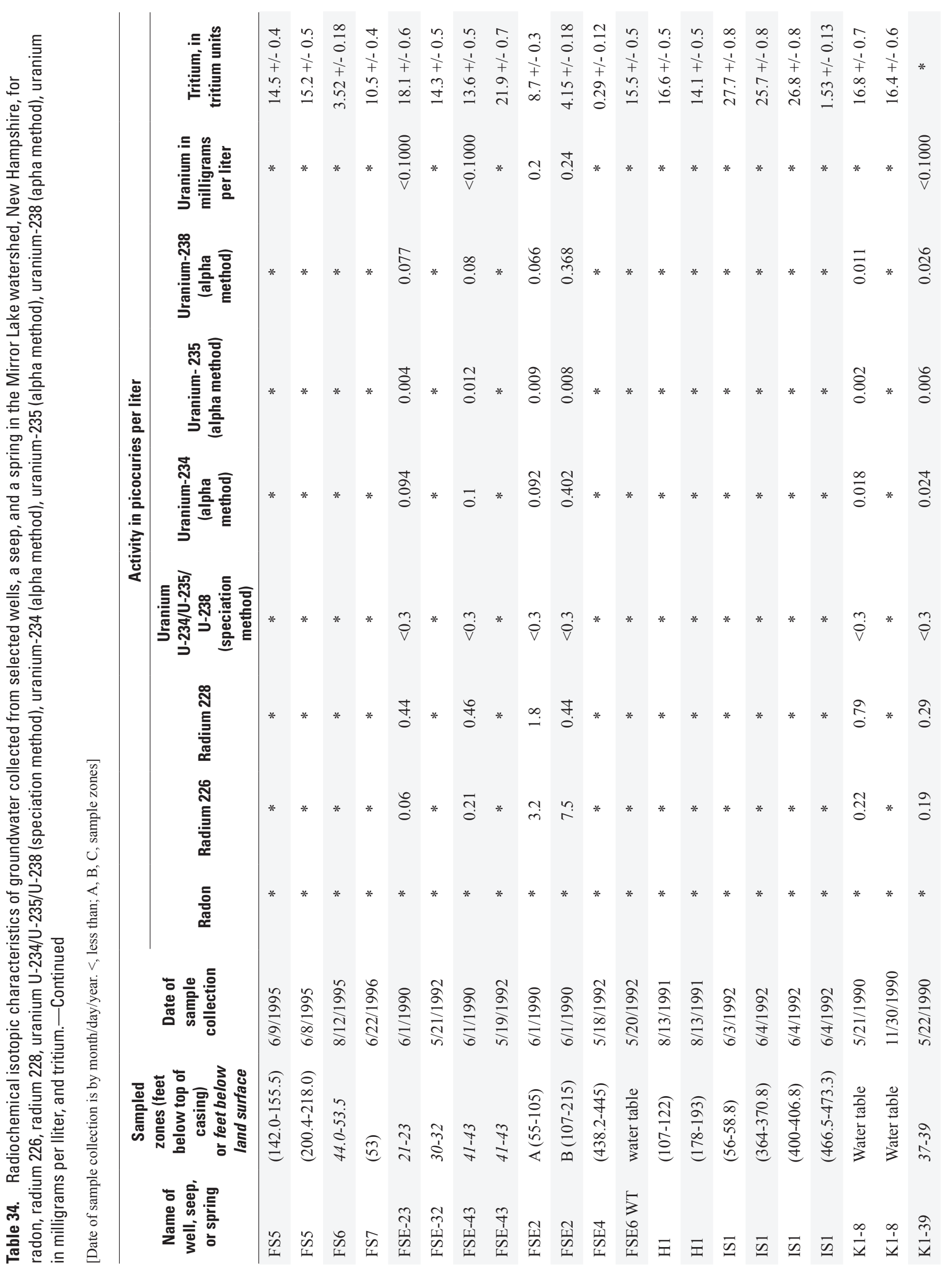


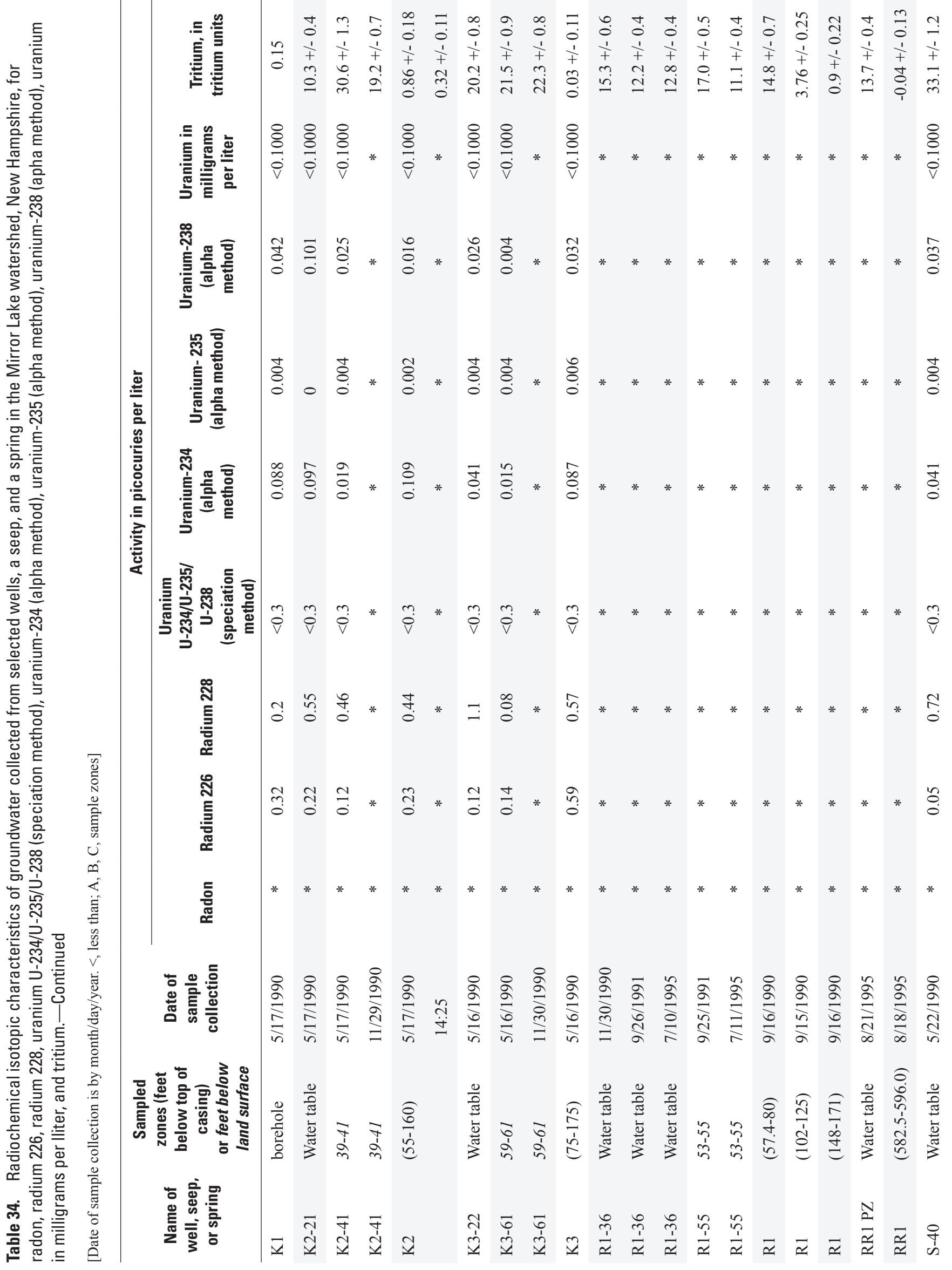




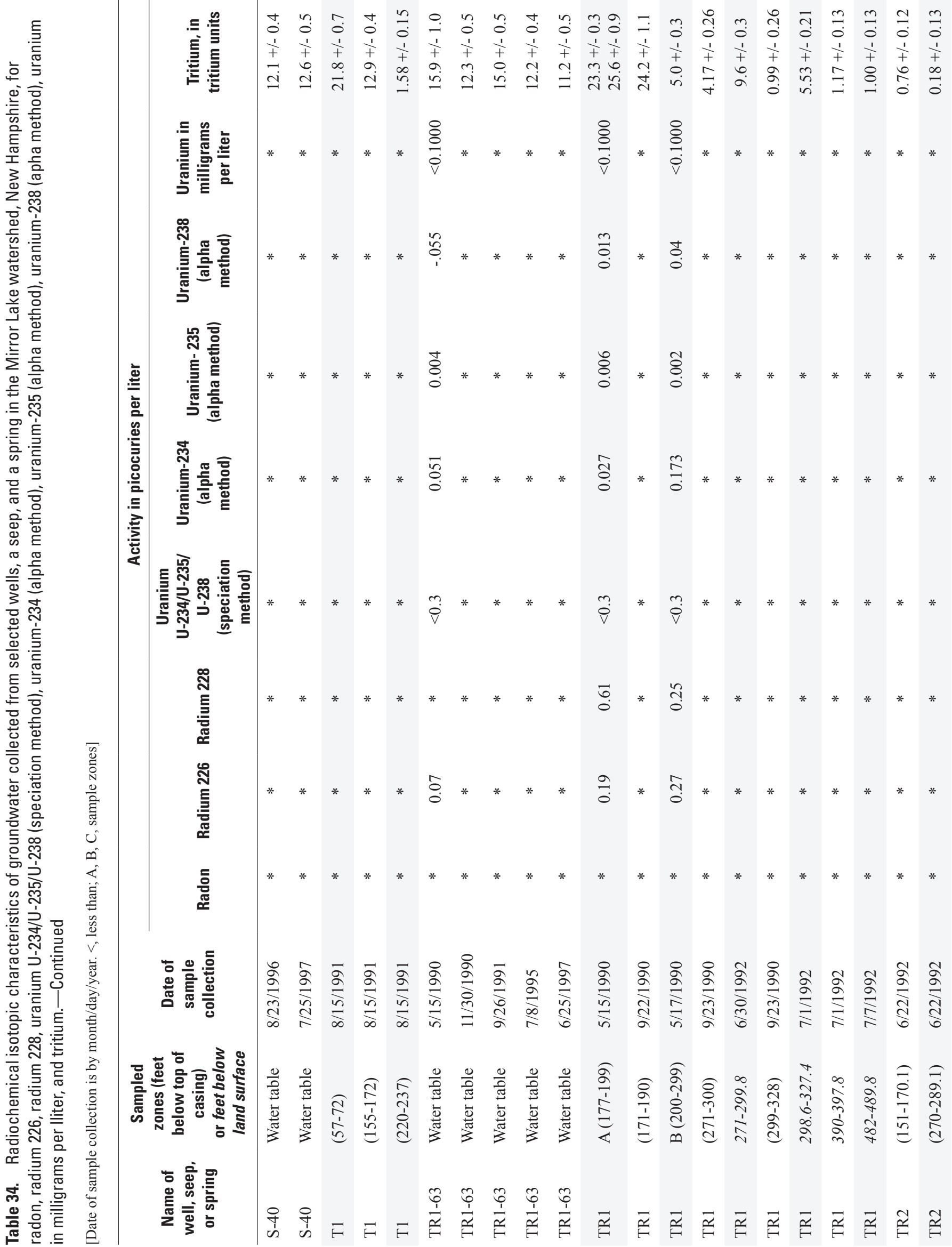




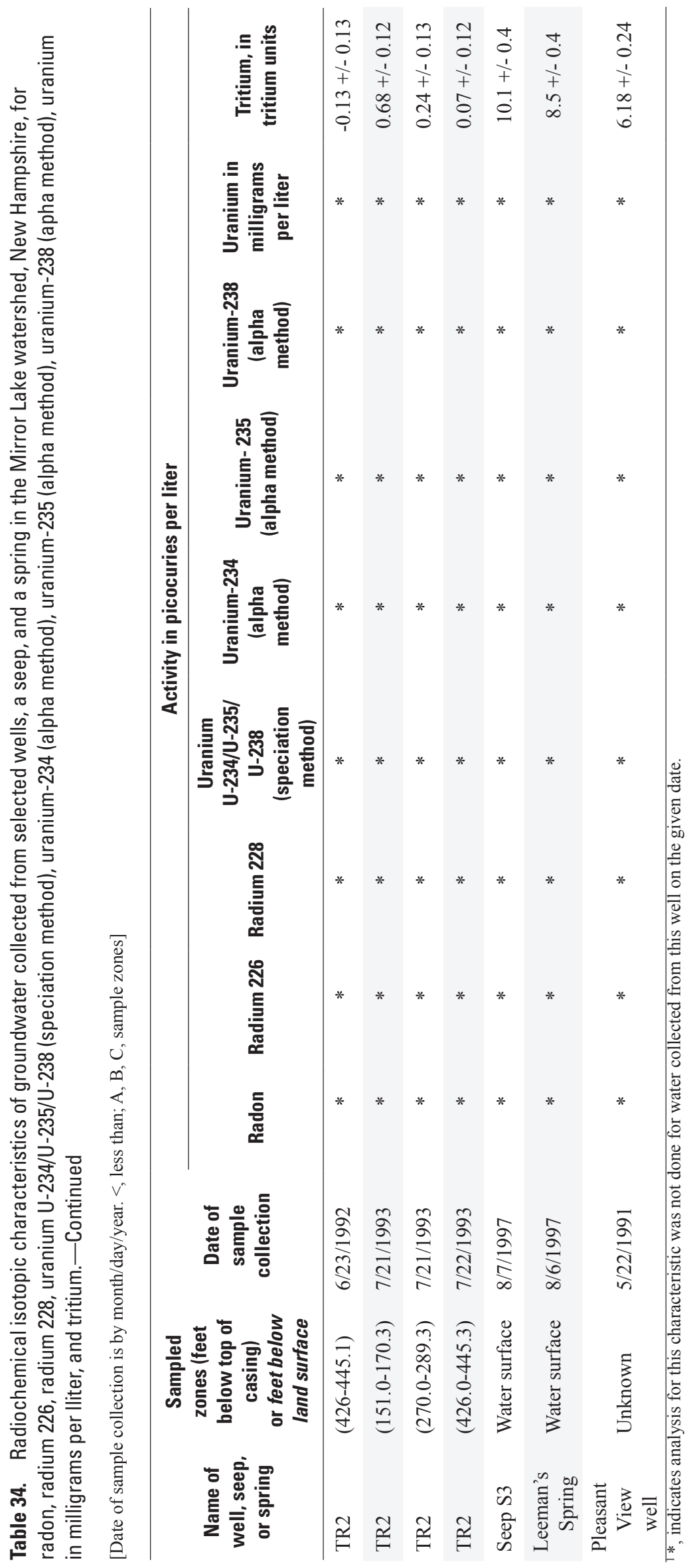


Table 35. Isotopic characteristics of groundwater collected from selected wells, a seep, and a spring in the Mirror Lake watershed, New Hampshire, for stable isotope ratios.

[Date of sample collection is by month/day/year. <, less than; A, B, C, sample zones; Values in the table are isotope ratios relative to reference materials of Standard Mean Ocean Water (SMOW), Vienna Pee Dee Belemnite (VPDB), and Canyon Diablo Troilite (CDT)]

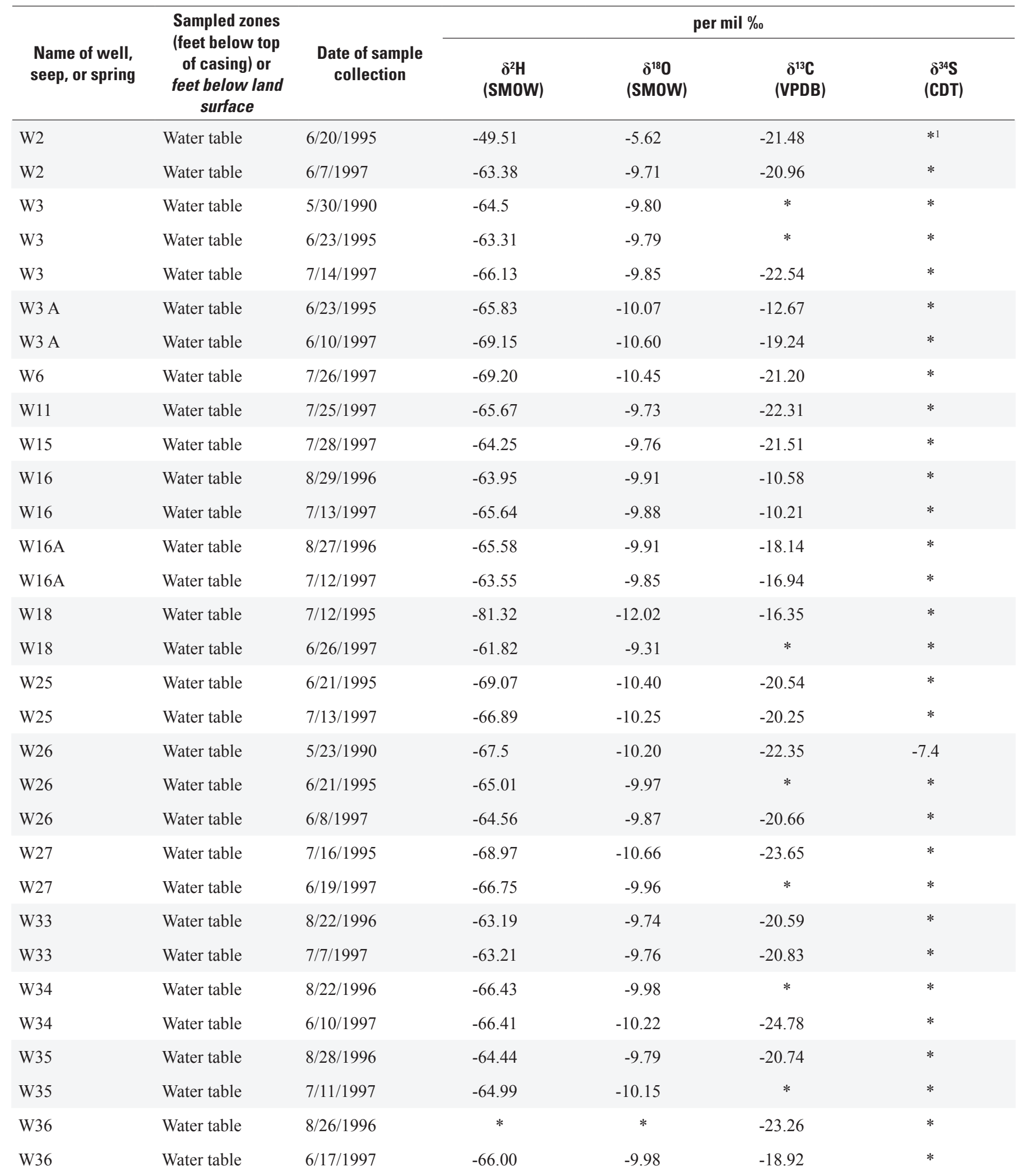


Table 35. Isotopic characteristics of groundwater collected from selected wells, a seep, and a spring in the Mirror Lake watershed, New Hampshire, for stable isotope ratios.-Continued

[Date of sample collection is by month/day/year. <, less than; A, B, C, sample zones; Values in the table are isotope ratios relative to reference materials of Standard Mean Ocean Water (SMOW), Vienna Pee Dee Belemnite (VPDB), and Canyon Diablo Troilite (CDT)]

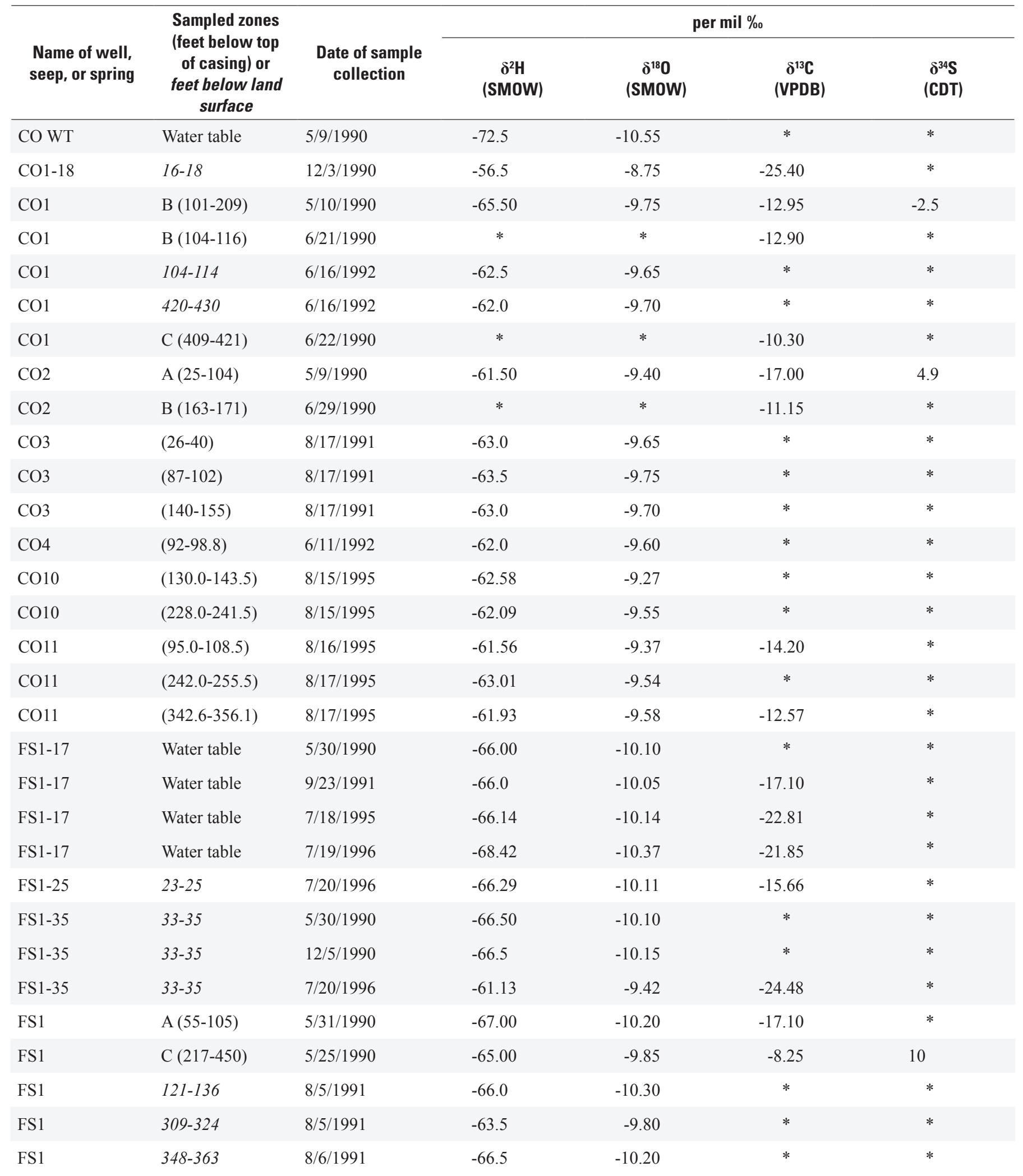


Table 35. Isotopic characteristics of groundwater collected from selected wells, a seep, and a spring in the Mirror Lake watershed, New Hampshire, for stable isotope ratios.-Continued

[Date of sample collection is by month/day/year. <, less than; A, B, C, sample zones; Values in the table are isotope ratios relative to reference materials of Standard Mean Ocean Water (SMOW), Vienna Pee Dee Belemnite (VPDB), and Canyon Diablo Troilite (CDT)]

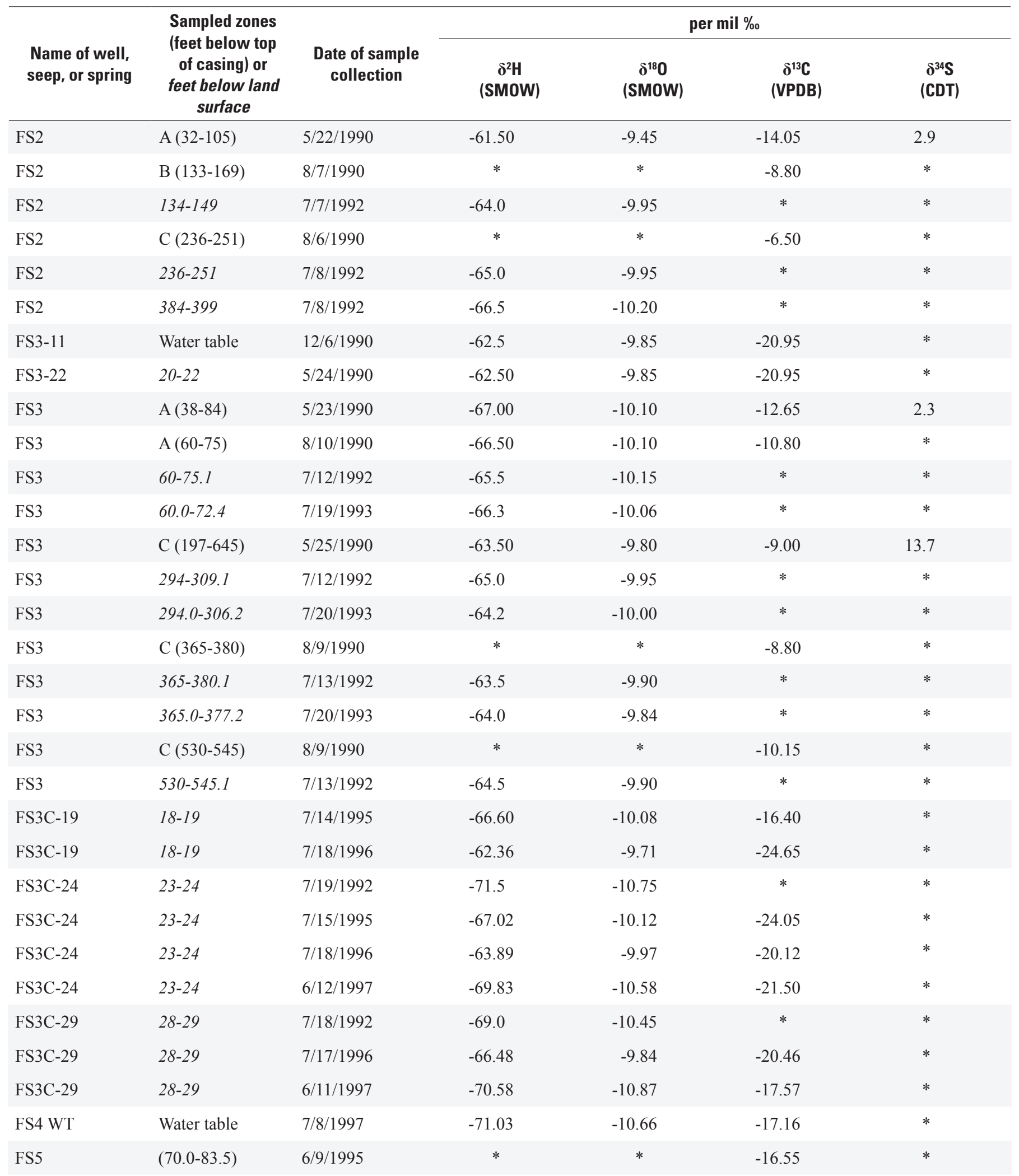


Table 35. Isotopic characteristics of groundwater collected from selected wells, a seep, and a spring in the Mirror Lake watershed, New Hampshire, for stable isotope ratios.-Continued

[Date of sample collection is by month/day/year. <, less than; A, B, C, sample zones; Values in the table are isotope ratios relative to reference materials of Standard Mean Ocean Water (SMOW), Vienna Pee Dee Belemnite (VPDB), and Canyon Diablo Troilite (CDT)]

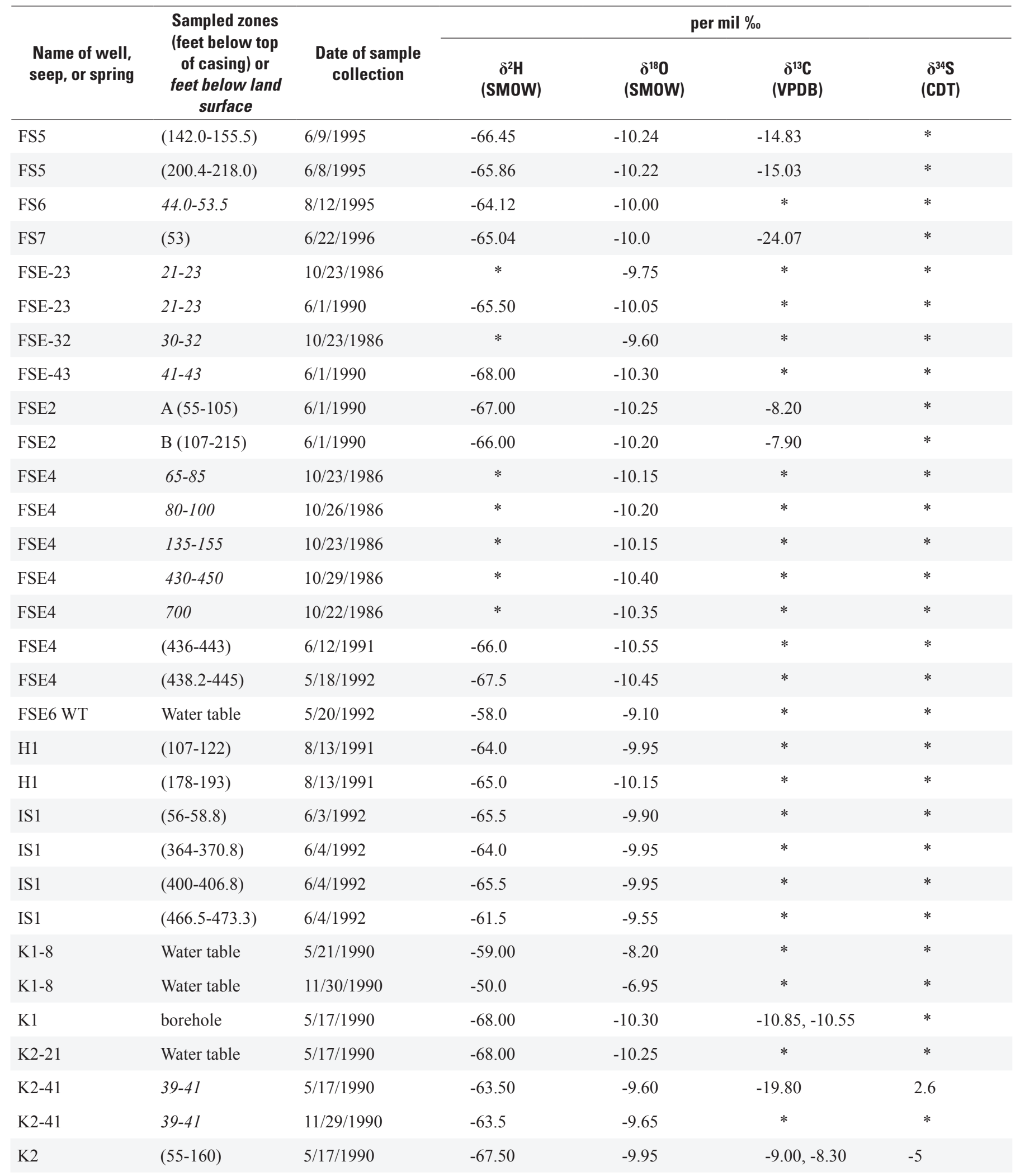


Table 35. Isotopic characteristics of groundwater collected from selected wells, a seep, and a spring in the Mirror Lake watershed, New Hampshire, for stable isotope ratios. - Continued

[Date of sample collection is by month/day/year. <, less than; A, B, C, sample zones; Values in the table are isotope ratios relative to reference materials of Standard Mean Ocean Water (SMOW), Vienna Pee Dee Belemnite (VPDB), and Canyon Diablo Troilite (CDT)]

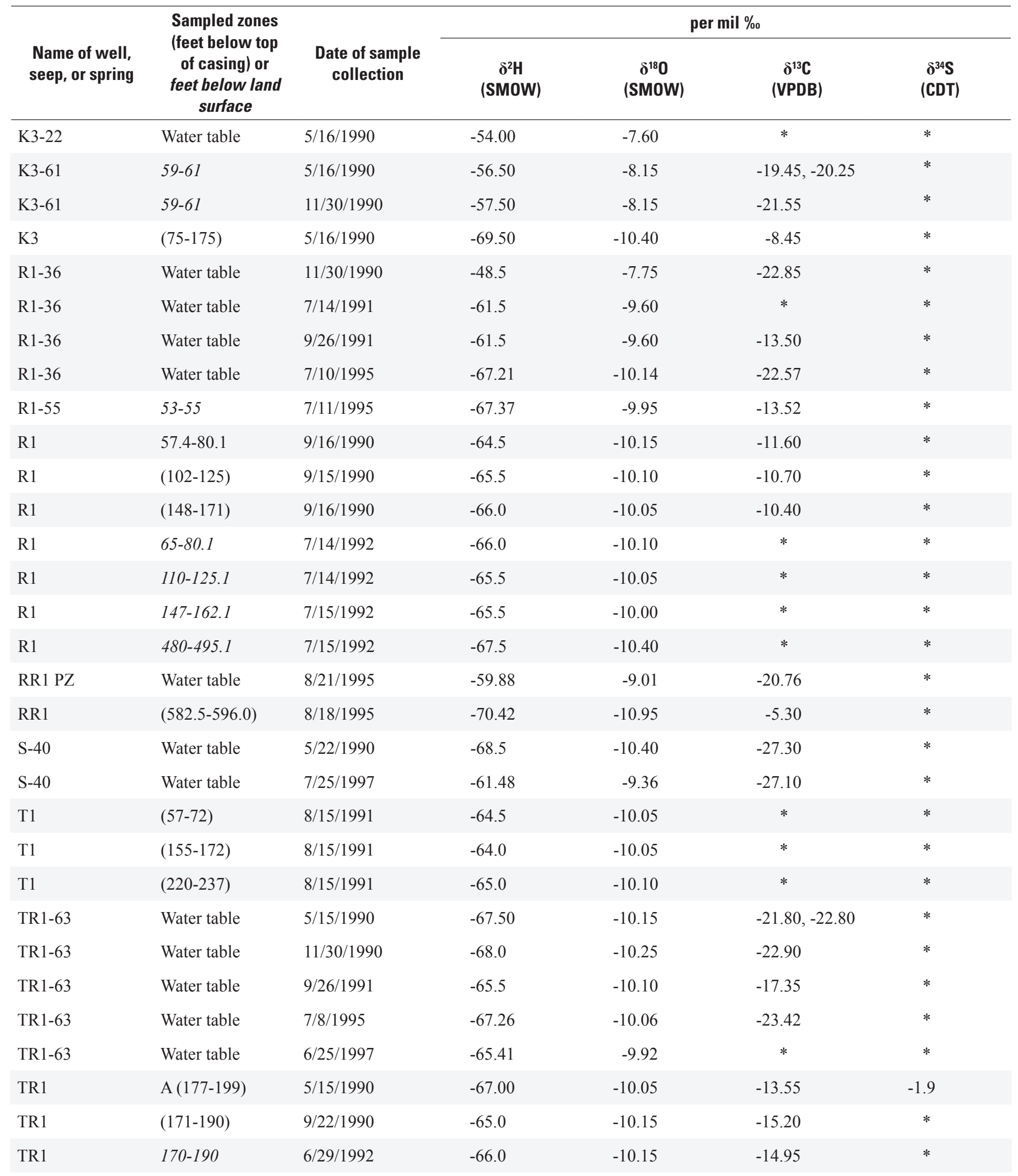


Table 35. Isotopic characteristics of groundwater collected from selected wells, a seep, and a spring in the Mirror Lake watershed, New Hampshire, for stable isotope ratios.-Continued

[Date of sample collection is by month/day/year. <, less than; A, B, C, sample zones; Values in the table are isotope ratios relative to reference materials of Standard Mean Ocean Water (SMOW), Vienna Pee Dee Belemnite (VPDB), and Canyon Diablo Troilite (CDT)]

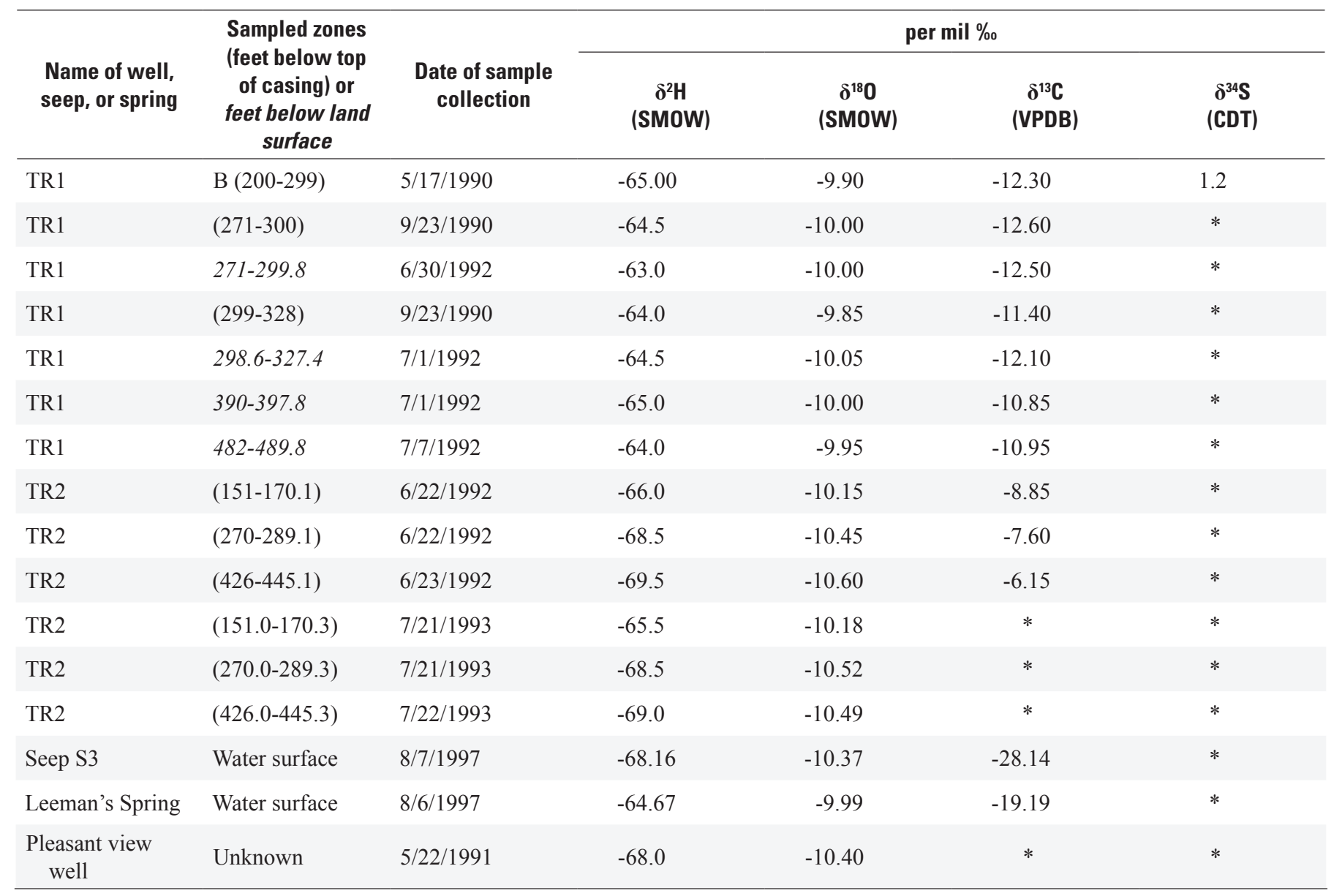

$1 *$, indicates analysis for this characteristic was not done for water collected from this well on the given date. 
Table 36. Isotopic characteristics of water collected over time from a single well (CO1) in the vicinity of Mirror Lake, New Hampshire, 1996 , for stable isotope ratios.

[Date of sample collection is by month/day/year; Values in the table are isotope ratios relative to reference materials of Standard Mean Ocean Water (SMOW) and Vienna Pee Dee Belemnite (VPDB)]

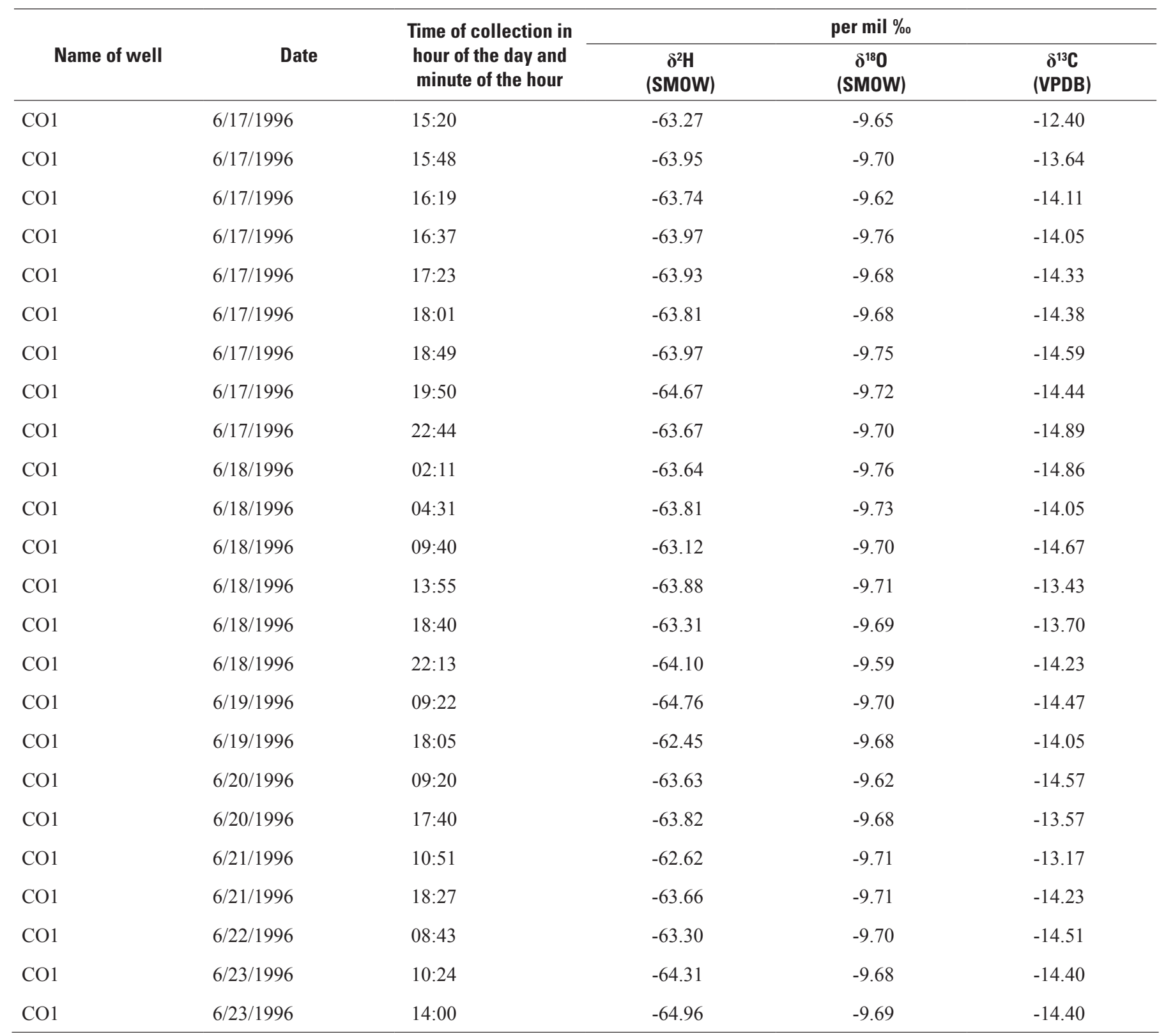


Table 37. Isotopic characteristics of water collected over time from a single well (CO1) in the vicinity of Mirror Lake, New Hampshire, 1996, for tritium.

[Date of sample collection is by month/day/year]

\begin{tabular}{llcc}
\hline Name of well & Date & $\begin{array}{c}\text { Time of collection in } \\
\text { hour of the day and } \\
\text { minute of the hour }\end{array}$ & Tritium, in tritium units \\
\hline $\mathrm{CO} 1$ & $6 / 17 / 1996$ & $15: 56$ & 8.9 \\
$\mathrm{CO} 1$ & $6 / 17 / 1996$ & $16: 35$ & 9.9 \\
$\mathrm{CO} 1$ & $6 / 17 / 1996$ & $17: 24$ & 10.2 \\
$\mathrm{CO} 1$ & $6 / 17 / 1996$ & $19: 55$ & 9.7 \\
$\mathrm{CO} 1$ & $6 / 18 / 1996$ & $02: 16$ & 10.1 \\
$\mathrm{CO} 1$ & $6 / 18 / 1996$ & $09: 46$ & 10.3 \\
$\mathrm{CO} 1$ & $6 / 18 / 1996$ & $18: 37$ & 9.7 \\
$\mathrm{CO} 1$ & $6 / 19 / 1996$ & $09: 25$ & 9.0 \\
$\mathrm{CO} 1$ & $6 / 19 / 1996$ & $18: 08$ & 9.9 \\
$\mathrm{CO} 1$ & $6 / 20 / 1996$ & $17: 46$ & 9.9 \\
$\mathrm{CO} 1$ & $6 / 21 / 1996$ & $10: 48$ & 9.4 \\
$\mathrm{CO} 1$ & $6 / 22 / 1996$ & $08: 38$ & 8.6 \\
$\mathrm{CO} 1$ & $6 / 23 / 1996$ & $14: 03$ & 9.6 \\
\hline
\end{tabular}


Tables $\quad 125$

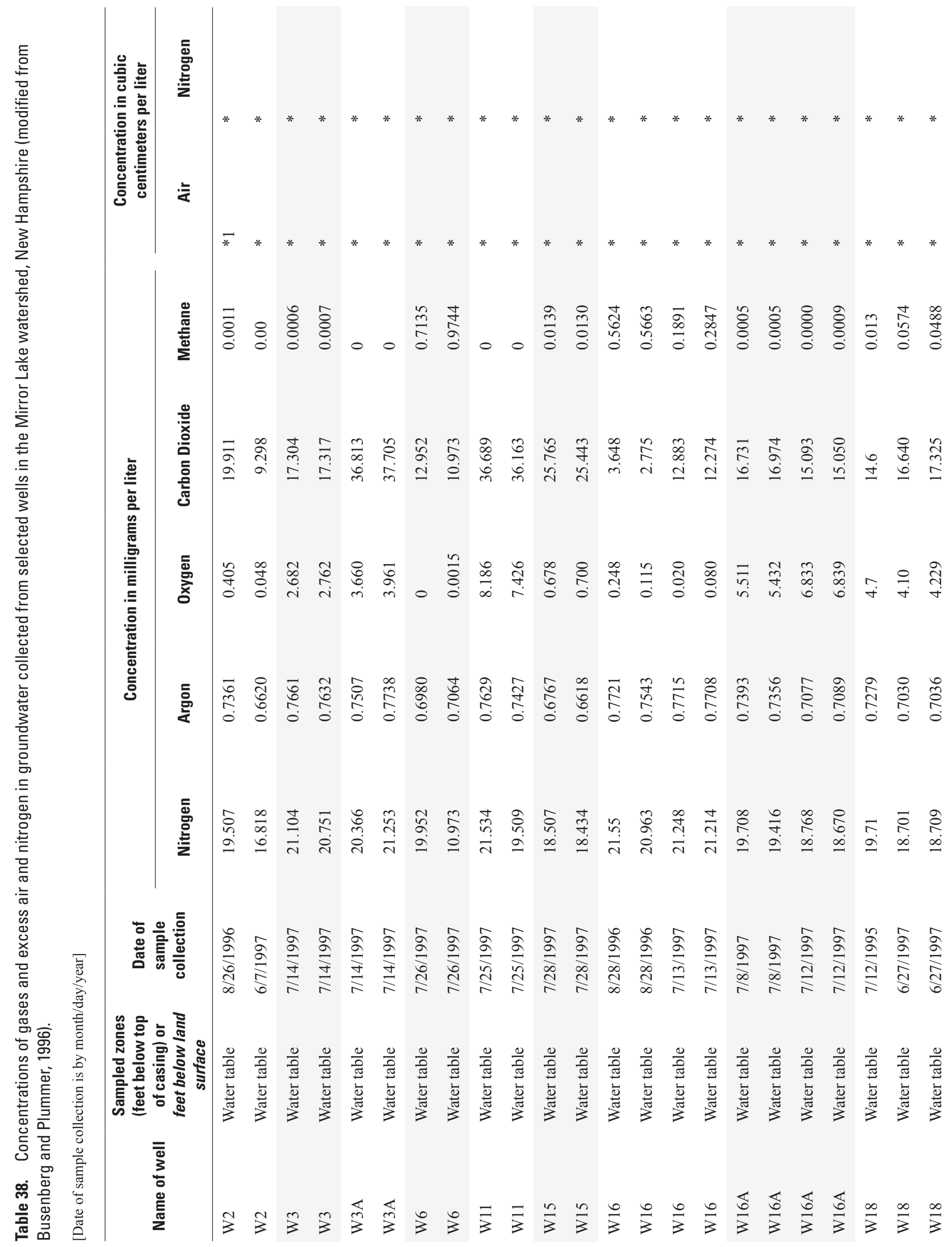




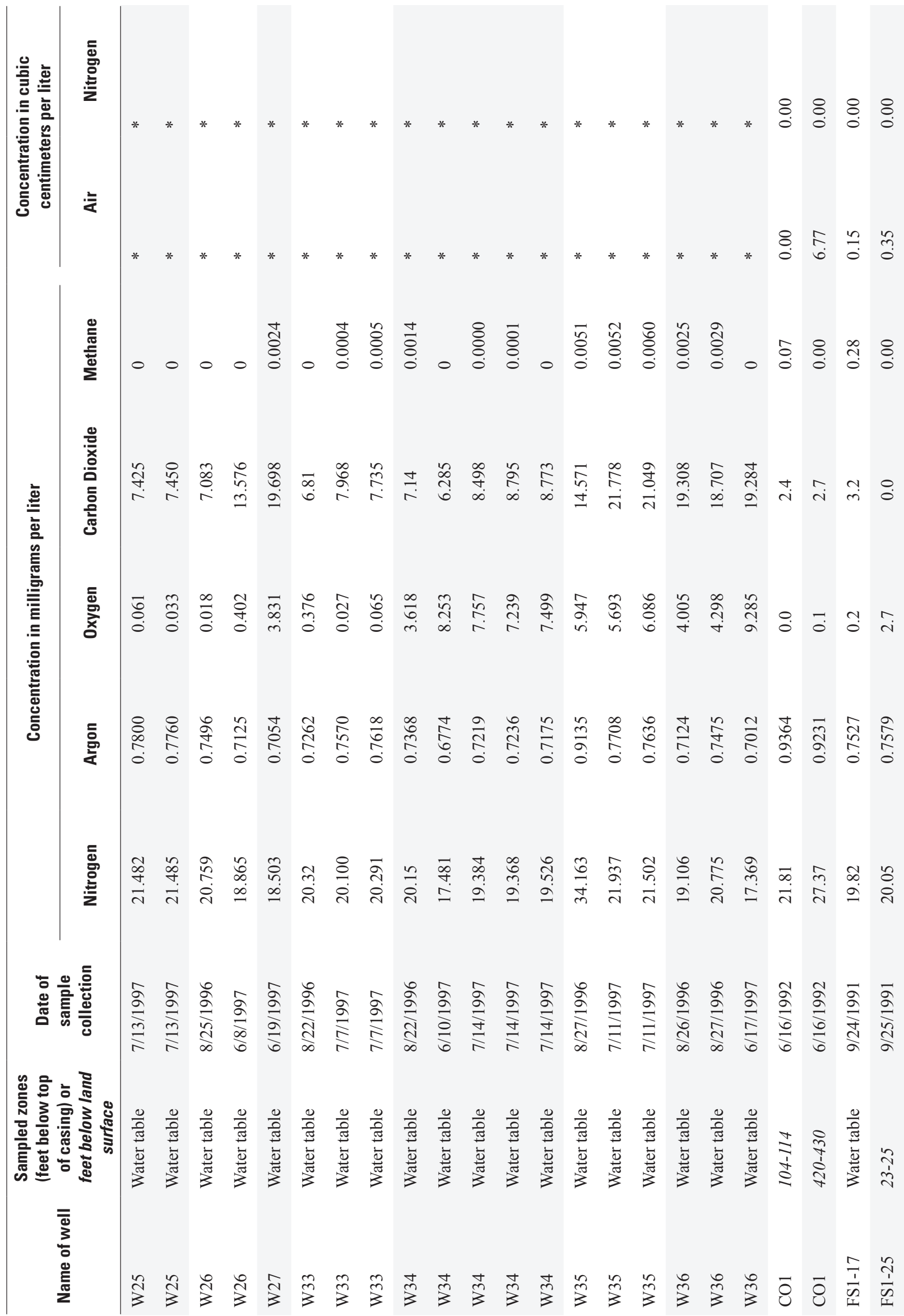


Tables 127

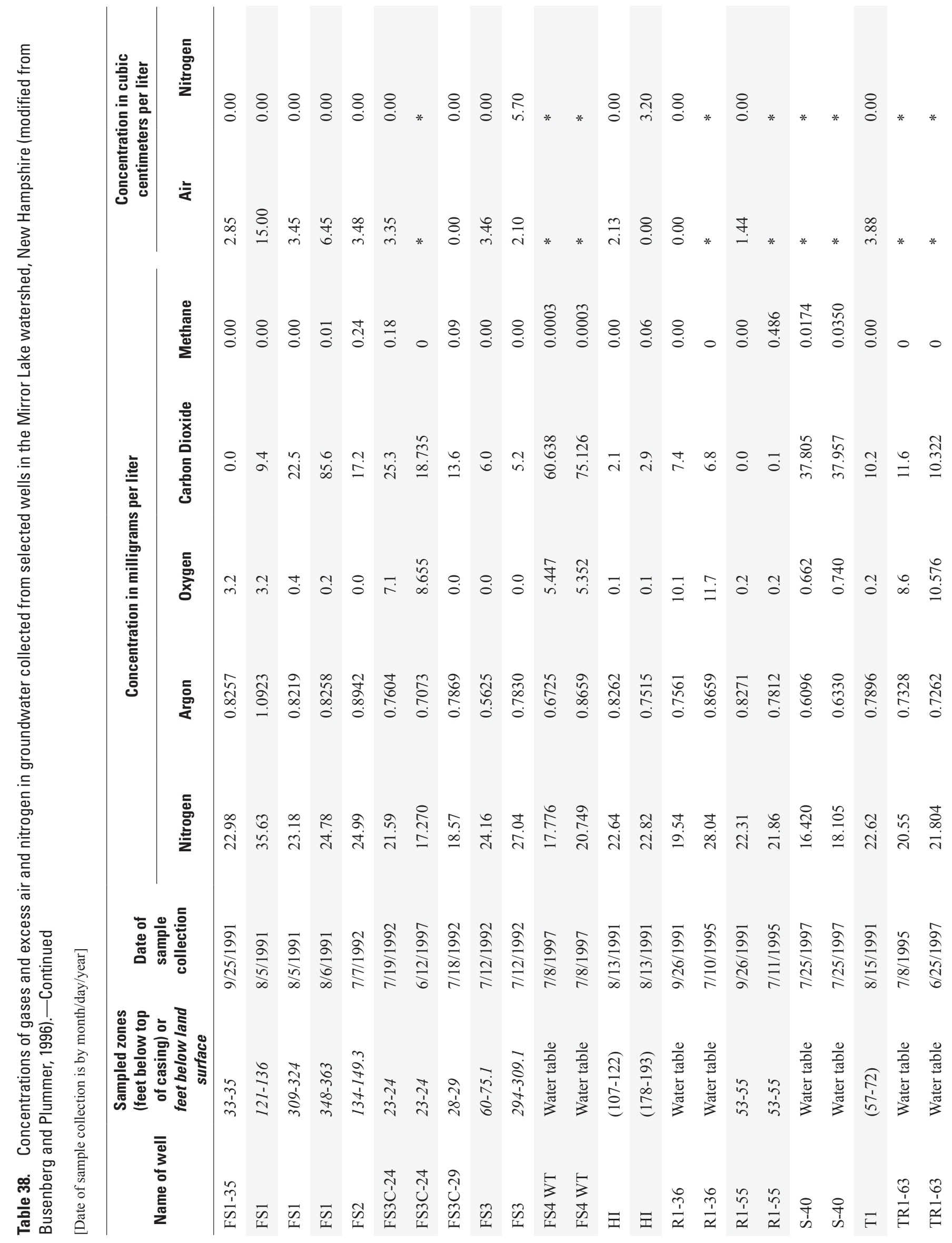




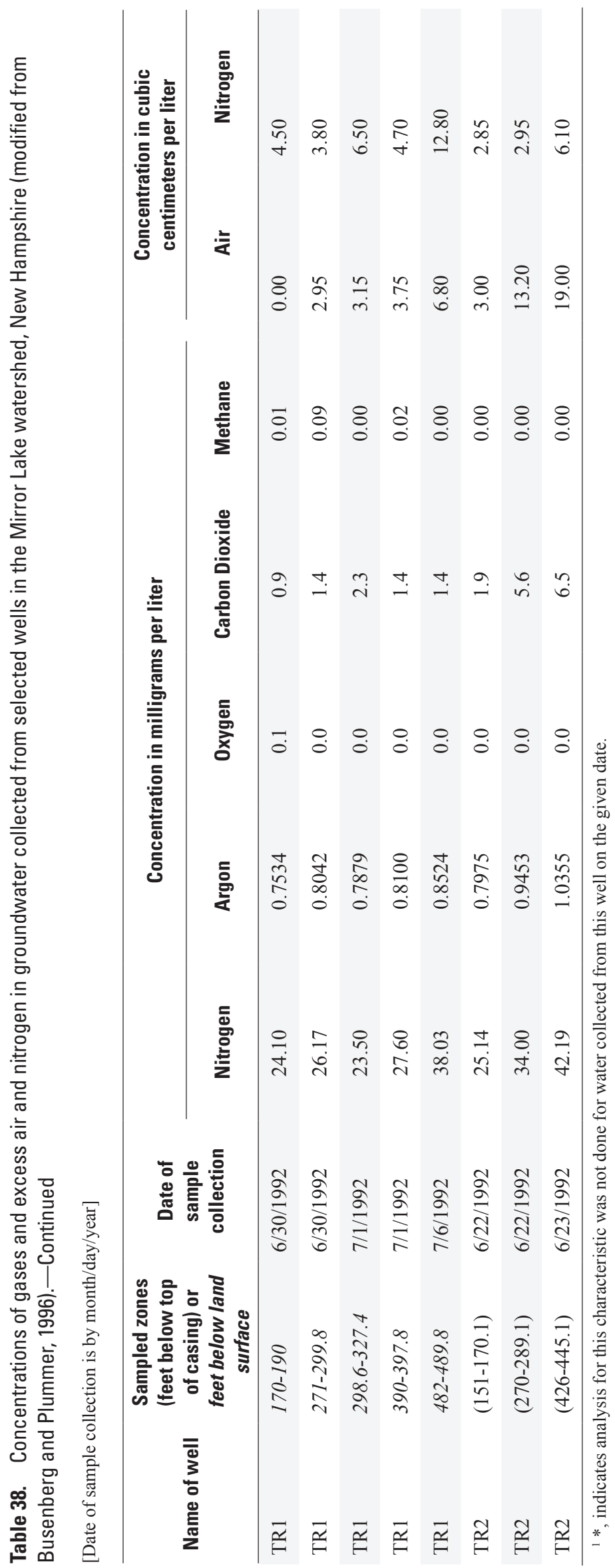


Table 39. Concentrations of gases dissolved in water collected from selected wells in the Mirror Lake watershed, New Hampshire: chlorofluorocarbons.

[Date of sample collection is by month/day/year; CFC, chlorofluorocarbon; $\mathrm{H}_{2} \mathrm{~S}$, hydrogen sulfide; $\mathrm{Cu}$, copper; S.C., specific conductance; “, inch]

\begin{tabular}{|c|c|c|c|c|c|c|c|c|}
\hline \multirow{2}{*}{$\begin{array}{l}\text { Name of } \\
\text { well }\end{array}$} & \multirow{2}{*}{$\begin{array}{l}\text { Sampled zones } \\
\text { (feet below } \\
\text { top of casing) } \\
\text { or feet below } \\
\text { land surface }\end{array}$} & \multirow{2}{*}{$\begin{array}{c}\text { Date of } \\
\text { sample } \\
\text { collection }\end{array}$} & \multirow{2}{*}{$\begin{array}{l}\text { Time of } \\
\text { collection }\end{array}$} & \multirow{2}{*}{$\begin{array}{l}\text { Sample } \\
\text { number }\end{array}$} & \multicolumn{3}{|c|}{$\begin{array}{c}\text { Concentration in solution, pictograms } \\
\text { per kilogram }\end{array}$} & \multirow{2}{*}{ Remarks } \\
\hline & & & & & CFC-11 & CFC-12 & CFC-113 & \\
\hline W2 & Water table & $6 / 20 / 1995$ & $* 1$ & 1 & 8.9 & 240 & 0 & \\
\hline W2 & Water table & $6 / 20 / 1995$ & $*$ & 2 & 11.2 & 250 & 0 & \\
\hline W3 & Water table & $6 / 23 / 1995$ & $*$ & 2 & 507.5 & 342.4 & 62.3 & \\
\hline W3 & Water table & $6 / 23 / 1995$ & $*$ & 3 & 507.9 & 340.2 & 62.7 & \\
\hline W3A & Water table & $6 / 23 / 1995$ & $*$ & 1 & 932.4 & 423.4 & 104.4 & \\
\hline W16 & Water table & 8/28/1996 & $*$ & 2 & 89.4 & 42.8 & 26.7 & \\
\hline W16 & Water table & $8 / 28 / 1996$ & $*$ & 3 & 94.3 & 40.9 & 29.6 & \\
\hline W16A & Water table & $8 / 27 / 1996$ & $*$ & 1 & 569.3 & 303.8 & 102.9 & \\
\hline W16A & Water table & $8 / 27 / 1996$ & $*$ & 2 & 600 & 430.4 & 107.3 & \\
\hline W16A & Water table & $8 / 27 / 1996$ & * & 3 & 664 & 313.1 & 98 & \\
\hline W18 & Water table & $7 / 12 / 1995$ & $*$ & 1 & 781.8 & 407.2 & 102.3 & \\
\hline W18 & Water table & $7 / 12 / 1995$ & $*$ & 2 & 727.8 & 374.3 & 105.6 & \\
\hline W26 & Water table & $6 / 21 / 1995$ & $*$ & 2 & 3.9 & 193.3 & 0 & \\
\hline W26 & Water table & $6 / 21 / 1995$ & $*$ & 3 & 4.6 & 180.1 & 0 & \\
\hline W27 & Water table & $7 / 16 / 1995$ & * & 1 & 784.5 & 390.6 & 102.5 & \\
\hline W27 & Water table & $7 / 16 / 1995$ & $*$ & 2 & 783.8 & 398.8 & 97.7 & \\
\hline W33 & Water table & $8 / 22 / 1996$ & $*$ & 1 & 389 & 254.8 & 15.7 & \\
\hline W33 & Water table & $8 / 22 / 1996$ & $*$ & 2 & 58.9 & 247.9 & 5.4 & \\
\hline W33 & Water table & $8 / 22 / 1996$ & $*$ & 3 & 514.1 & 234.9 & 13.9 & \\
\hline W36 & Water table & $8 / 26 / 1996$ & $*$ & 1 & 753.8 & 385.6 & 115.3 & \\
\hline W36 & Water table & $8 / 26 / 1996$ & $*$ & 2 & 737.8 & 387.9 & 190.7 & \\
\hline W36 & Water table & $8 / 26 / 1996$ & $*$ & 3 & 734.4 & 430.6 & 230.1 & \\
\hline $\mathrm{CO} 1$ & $104-114$ & $6 / 16 / 1992$ & 1206 & 1 & 385.6 & 80.8 & 4.4 & \\
\hline
\end{tabular}


Table 39. Concentrations of gases dissolved in water collected from selected wells in the Mirror Lake watershed, New Hampshire: chlorofluorocarbons.-Continued

[Date of sample collection is by month/day/year; $\mathrm{CFC}$, chlorofluorocarbon; $\mathrm{H}_{2} \mathrm{~S}$, hydrogen sulfide; Cu, copper; S.C., specific conductance; “, inch]

\begin{tabular}{|c|c|c|c|c|c|c|c|c|}
\hline \multirow{2}{*}{$\begin{array}{l}\text { Name of } \\
\text { well }\end{array}$} & \multirow{2}{*}{$\begin{array}{l}\text { Sampled zones } \\
\text { (feet below } \\
\text { top of casing) } \\
\text { or feet below } \\
\text { land surface }\end{array}$} & \multirow{2}{*}{$\begin{array}{c}\text { Date of } \\
\text { sample } \\
\text { collection }\end{array}$} & \multirow{2}{*}{$\begin{array}{l}\text { Time of } \\
\text { collection }\end{array}$} & \multirow{2}{*}{$\begin{array}{l}\text { Sample } \\
\text { number }\end{array}$} & \multicolumn{3}{|c|}{$\begin{array}{c}\text { Concentration in solution, pictograms } \\
\text { per kilogram }\end{array}$} & \multirow{2}{*}{ Remarks } \\
\hline & & & & & CFC-11 & CFC-12 & CFC-113 & \\
\hline $\mathrm{CO} 1$ & $104-114$ & $6 / 16 / 1992$ & 1213 & 2 & 521.0 & 89.2 & 0.0 & \\
\hline $\mathrm{CO} 1$ & $104-114$ & $6 / 16 / 1992$ & 1221 & 3 & 303.3 & 76.0 & 2.1 & \\
\hline $\mathrm{CO} 1$ & $104-114$ & $6 / 16 / 1992$ & 1250 & 5 & 119.1 & 81.8 & 3.0 & \\
\hline $\mathrm{CO} 1$ & $104-114$ & $6 / 16 / 1992$ & 1300 & 6 & 88.2 & 79.4 & 0.0 & \\
\hline $\mathrm{CO} 1$ & $420-430$ & $6 / 16 / 1992$ & 1515 & 1 & 33.3 & 30.2 & 0.0 & \\
\hline $\mathrm{CO} 1$ & $420-430$ & 6/16/1992 & 1635 & 5 & 31.0 & 30.7 & 0.0 & \\
\hline $\mathrm{CO} 1$ & $420-430$ & 6/16/1992 & 1640 & 6 & 39.3 & 29.0 & 0.0 & \\
\hline $\mathrm{CO} 3$ & $(26-40)$ & 8/17/1991 & 1701 & $\#^{2}$ & 95.0 & 463.4 & $\mathrm{ERR}^{3}$ & \\
\hline $\mathrm{CO} 3$ & $(26-40)$ & 8/17/1991 & 1726 & \# & 85.0 & 483.2 & ERR & Little $\mathrm{H}_{2} \mathrm{~S}$ \\
\hline $\mathrm{CO} 3$ & $(26-40)$ & 8/17/1991 & 1734 & \# & 83.2 & 479.2 & ERR & \\
\hline $\mathrm{CO} 3$ & $(87-102)$ & 8/17/1991 & 1400 & \# & 48.8 & 127.9 & ERR & \\
\hline $\mathrm{CO} 3$ & $(87-102)$ & $8 / 17 / 1991$ & 1415 & \# & 50.1 & 116.2 & ERR & \\
\hline $\mathrm{CO} 4$ & $(92-98.8)$ & $6 / 11 / 1992$ & 1251 & 1 & 244.4 & 158.6 & 20.2 & \\
\hline $\mathrm{CO} 4$ & $(92-98.8)$ & 6/11/1992 & 1258 & 2 & 271.9 & 146.8 & 52.6 & \\
\hline $\mathrm{CO} 4$ & $(92-98.8)$ & $6 / 11 / 1992$ & 1304 & 3 & 318.8 & 157.8 & 34.7 & \\
\hline $\mathrm{CO} 4$ & $(92-98.8)$ & $6 / 11 / 1992$ & 1331 & 4 & 386.1 & 154.5 & 213.6 & \\
\hline $\mathrm{CO} 4$ & $(92-98.8)$ & $6 / 11 / 1992$ & 1334 & 5 & 366.9 & 162.0 & 141.9 & \\
\hline $\mathrm{CO} 4$ & $(92-98.8)$ & 6/11/1992 & 1340 & 6 & 387.1 & 153.6 & 250.0 & \\
\hline FS1-17 & Water table & 9/24/1991 & 1000 & 1 & $93,907.1$ & $2,313.4$ & ERR & $\begin{array}{l}80 \mathrm{~mL} / \mathrm{min}, 1 / 2 " \\
\quad \text { Nylon }\end{array}$ \\
\hline FS1-17 & Water table & 9/24/1991 & 1045 & 3 & $110,606.3$ & $1,326.8$ & ERR & Trace $\mathrm{H}_{2} \mathrm{~S}$ \\
\hline FS1-17 & Water table & 9/24/1991 & 1150 & 1 & $124,032.8$ & $1,599.2$ & ERR & $1 / 4 " \mathrm{Cu}$ \\
\hline FS1-17 & Water table & 9/24/1991 & 1210 & 2 & $93,608.4$ & 579.9 & ERR & Little $\mathrm{H}_{2} \mathrm{~S}$ \\
\hline FS1-17 & Water table & $7 / 18 / 1995$ & $*$ & 1 & $9,025.8$ & 392.8 & ERR & \\
\hline
\end{tabular}


Table 39. Concentrations of gases dissolved in water collected from selected wells in the Mirror Lake watershed, New Hampshire: chlorofluorocarbons.-Continued

[Date of sample collection is by month/day/year; CFC, chlorofluorocarbon; $\mathrm{H}_{2} \mathrm{~S}$, hydrogen sulfide; $\mathrm{Cu}$, copper; S.C., specific conductance; “, inch]

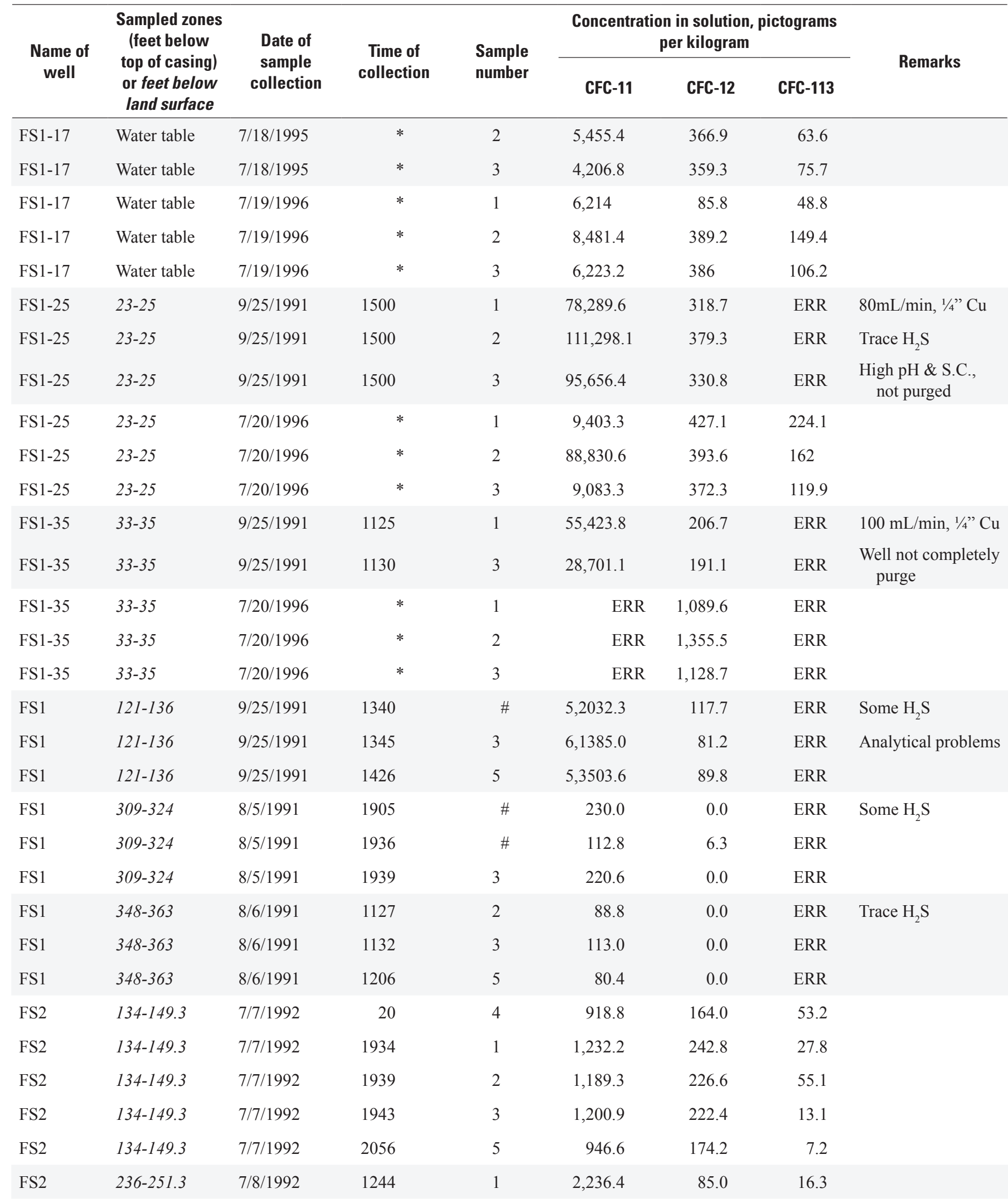


Table 39. Concentrations of gases dissolved in water collected from selected wells in the Mirror Lake watershed, New Hampshire: chlorofluorocarbons.-Continued

[Date of sample collection is by month/day/year; $\mathrm{CFC}$, chlorofluorocarbon; $\mathrm{H}_{2} \mathrm{~S}$, hydrogen sulfide; Cu, copper; S.C., specific conductance; “, inch]

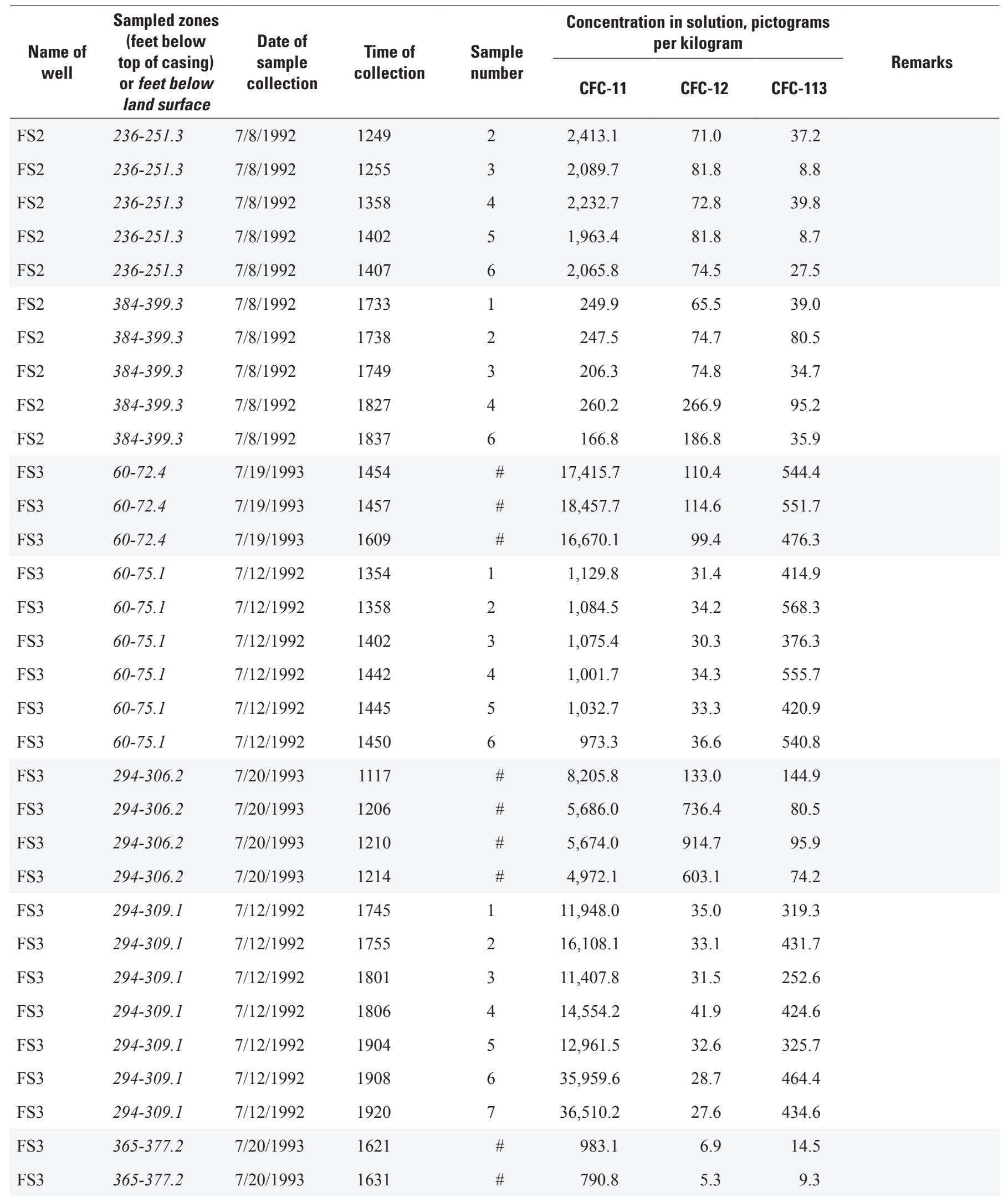


Table 39. Concentrations of gases dissolved in water collected from selected wells in the Mirror Lake watershed, New Hampshire: chlorofluorocarbons.-Continued

[Date of sample collection is by month/day/year; CFC, chlorofluorocarbon; $\mathrm{H}_{2} \mathrm{~S}$, hydrogen sulfide; Cu, copper; S.C., specific conductance; “, inch]

\begin{tabular}{|c|c|c|c|c|c|c|c|c|}
\hline \multirow{2}{*}{$\begin{array}{l}\text { Name of } \\
\text { well }\end{array}$} & \multirow{2}{*}{$\begin{array}{l}\text { Sampled zones } \\
\text { (feet below } \\
\text { top of casing) } \\
\text { or feet below } \\
\text { land surface }\end{array}$} & \multirow{2}{*}{$\begin{array}{l}\text { Date of } \\
\text { sample } \\
\text { collection }\end{array}$} & \multirow{2}{*}{$\begin{array}{l}\text { Time of } \\
\text { collection }\end{array}$} & \multirow{2}{*}{$\begin{array}{l}\text { Sample } \\
\text { number }\end{array}$} & \multicolumn{3}{|c|}{$\begin{array}{c}\text { Concentration in solution, pictograms } \\
\text { per kilogram }\end{array}$} & \multirow{2}{*}{ Remarks } \\
\hline & & & & & CFC-11 & CFC-12 & CFC-113 & \\
\hline FS3 & $365-377.2$ & $7 / 20 / 1993$ & 1635 & $\#$ & 800.2 & 6.1 & 10.1 & \\
\hline FS3 & $365-380.1$ & 7/13/1992 & 1019 & 1 & $9,514.3$ & 20.5 & 88.5 & \\
\hline FS3 & $365-380.1$ & 7/13/1992 & 1027 & 3 & $9,005.9$ & 19.2 & 131.5 & \\
\hline FS3 & $365-380.1$ & 7/13/1992 & 1047 & 4 & $8,070.6$ & 17.3 & 241.7 & \\
\hline FS3 & $365-380.1$ & 7/13/1992 & 1054 & 5 & $7,270.9$ & 15.8 & 98.2 & \\
\hline FS3 & $530-545.1$ & 7/13/1992 & 1401 & 4 & $6,120.0$ & 21.8 & 20.2 & \\
\hline FS3 & $530-545.1$ & 7/13/1992 & 1408 & 5 & $5,687.5$ & 19.9 & 10.9 & \\
\hline FS3 & $530-545.1$ & 7/13/1992 & 1420 & 6 & $6,039.0$ & 18.8 & 6.8 & \\
\hline FS3C-19 & $18-19$ & $7 / 14 / 1995$ & $*$ & 1 & $1,110.7$ & 408.7 & 118 & \\
\hline FS3C-19 & $18-19$ & 7/14/1995 & $*$ & 2 & $1,096.3$ & 417.3 & 131.3 & \\
\hline FS3C-19 & $18-19$ & $7 / 14 / 1995$ & $*$ & 3 & $1,060.5$ & 419.9 & 129.5 & \\
\hline FS3C-19 & $18-19$ & 7/18/1996 & $*$ & 1 & 812.9 & 389.3 & 163.6 & \\
\hline FS3C-24 & $23-24$ & 7/19/1992 & 1738 & 4 & $1,223.0$ & 459.0 & 78.4 & \\
\hline FS3C-24 & $23-24$ & $7 / 15 / 1995$ & $*$ & 1 & $1,116.5$ & 439.2 & 242.9 & \\
\hline FS3C-24 & $23-24$ & $7 / 15 / 1995$ & $*$ & 2 & $1,135.2$ & 461.1 & 214.5 & \\
\hline FS3C-24 & $23-24$ & $7 / 15 / 1995$ & $*$ & 3 & $1,092.7$ & 439.2 & 205 & \\
\hline FS3C-24 & $23-24$ & 7/18/1996 & $*$ & 1 & 939.8 & 396.5 & 154.2 & \\
\hline FS3C-24 & $23-24$ & 7/18/1996 & $*$ & 2 & 953.1 & 402.7 & 161.1 & \\
\hline FS3C-24 & $23-24$ & 7/18/1996 & $*$ & 3 & 976.1 & 386.2 & 145.8 & \\
\hline FS3C-29 & $28-29$ & 7/18/1992 & 1906 & 2 & $1,505.3$ & 446.1 & 158.8 & \\
\hline FS3C-29 & $28-29$ & 7/18/1992 & 1940 & 4 & $1,106.3$ & 405.5 & 108.6 & \\
\hline FS3C-29 & $28-29$ & 7/18/1992 & 1946 & 5 & $1,215.4$ & 391.5 & 48.7 & \\
\hline FS3C-29 & $28-29$ & 7/18/1992 & 1951 & 6 & $2,136.3$ & 414.1 & 110.1 & \\
\hline
\end{tabular}


Table 39. Concentrations of gases dissolved in water collected from selected wells in the Mirror Lake watershed, New Hampshire: chlorofluorocarbons.-Continued

[Date of sample collection is by month/day/year; $\mathrm{CFC}$, chlorofluorocarbon; $\mathrm{H}_{2} \mathrm{~S}$, hydrogen sulfide; Cu, copper; S.C., specific conductance; “, inch]

\begin{tabular}{|c|c|c|c|c|c|c|c|c|}
\hline \multirow{2}{*}{$\begin{array}{l}\text { Name of } \\
\text { well }\end{array}$} & \multirow{2}{*}{$\begin{array}{l}\text { Sampled zones } \\
\text { (feet below } \\
\text { top of casing) } \\
\text { or feet below } \\
\text { land surface }\end{array}$} & \multirow{2}{*}{$\begin{array}{c}\text { Date of } \\
\text { sample } \\
\text { collection }\end{array}$} & \multirow{2}{*}{$\begin{array}{l}\text { Time of } \\
\text { collection }\end{array}$} & \multirow{2}{*}{$\begin{array}{l}\text { Sample } \\
\text { number }\end{array}$} & \multicolumn{3}{|c|}{$\begin{array}{c}\text { Concentration in solution, pictograms } \\
\text { per kilogram }\end{array}$} & \multirow{2}{*}{ Remarks } \\
\hline & & & & & CFC-11 & CFC-12 & CFC-113 & \\
\hline FS3C-29 & $28-29$ & $7 / 17 / 1996$ & $*$ & 1 & 952.3 & 382.2 & 182.8 & \\
\hline FS3C-29 & $28-29$ & 7/17/1996 & * & 2 & 680 & 281.7 & 130.1 & \\
\hline FSE-32 & $30-32$ & $5 / 27 / 1992$ & 1118 & \# & $19,383.9$ & 564.9 & 338.7 & \\
\hline FSE-32 & $30-32$ & $5 / 27 / 1992$ & 1208 & \# & $19,887.8$ & 386.7 & 278.5 & \\
\hline FSE-32 & $30-32$ & $5 / 27 / 1992$ & 1524 & $\#$ & $18,717.7$ & 363.5 & 111.4 & \\
\hline FSE-43 & $41-43$ & $5 / 19 / 1992$ & 1459 & \# & $1,884.4$ & 574.8 & 63.1 & \\
\hline FSE-43 & $41-43$ & $5 / 19 / 1992$ & 1502 & \# & $36,869.4$ & $1,706.0$ & 1691.5 & \\
\hline FSE-43 & $41-43$ & $5 / 19 / 1992$ & 1506 & \# & $3,799.2$ & $1,670.6$ & 100.3 & \\
\hline FSE-43 & $41-43$ & $5 / 19 / 1992$ & 1747 & \# & $13,882.7$ & 312.1 & 16.4 & \\
\hline FSE-43 & $41-43$ & $5 / 19 / 1992$ & 1750 & \# & $19,505.3$ & 236.4 & 15.4 & \\
\hline FSE-43 & $41-43$ & $5 / 19 / 1992$ & 1756 & \# & $18,768.5$ & 310.6 & 52.9 & \\
\hline FSE4 & $(438.2-445.0)$ & $5 / 18 / 1992$ & 1700 & \# & 373.7 & 5.2 & 24.9 & \\
\hline FSE5 & $108.0-115.0$ & 9/16/1991 & 1121 & \# & 94.0 & 24.2 & ERR & Little $\mathrm{H}_{2} \mathrm{~S}$ \\
\hline FSE5 & $108.0-115.0$ & 9/16/1991 & 1206 & \# & 105.2 & 22.4 & ERR & New \\
\hline FSE5 & $108.0-115.0$ & 9/16/1991 & 1240 & \# & 90.1 & 18.2 & ERR & New \\
\hline FSE5 & $108.0-115.0$ & 9/16/1991 & 1526 & \# & 95.4 & 14.8 & ERR & \\
\hline FSE5 & $108.0-115.0$ & 9/16/1991 & 1730 & \# & 105.4 & 14.8 & ERR & \\
\hline FSE5 & $108.0-115.0$ & 9/16/1991 & 1734 & \# & 127.7 & 21.2 & ERR & New \\
\hline FSE5 & $108.0-115.0$ & 9/16/1991 & 1830 & \# & 79.8 & 24.4 & ERR & New \\
\hline FSE5 & $108.0-115.0$ & 9/16/1991 & 1933 & \# & 111.1 & 18.9 & ERR & New \\
\hline FSE5 & $108.0-115.0$ & 9/17/1991 & 0837 & \# & 104.7 & 28.3 & ERR & New \\
\hline FSE5 & $108.0-115.0$ & 9/17/1991 & 1039 & $\#$ & 122.3 & 15.6 & ERR & Little $\mathrm{H}_{2} \mathrm{~S}$ \\
\hline FSE5 & $108.0-115.0$ & 9/17/1991 & 1045 & \# & 96.1 & 16.6 & ERR & \\
\hline
\end{tabular}


Table 39. Concentrations of gases dissolved in water collected from selected wells in the Mirror Lake watershed, New Hampshire: chlorofluorocarbons.-Continued

[Date of sample collection is by month/day/year; CFC, chlorofluorocarbon; $\mathrm{H}_{2} \mathrm{~S}$, hydrogen sulfide; Cu, copper; S.C., specific conductance; “, inch]

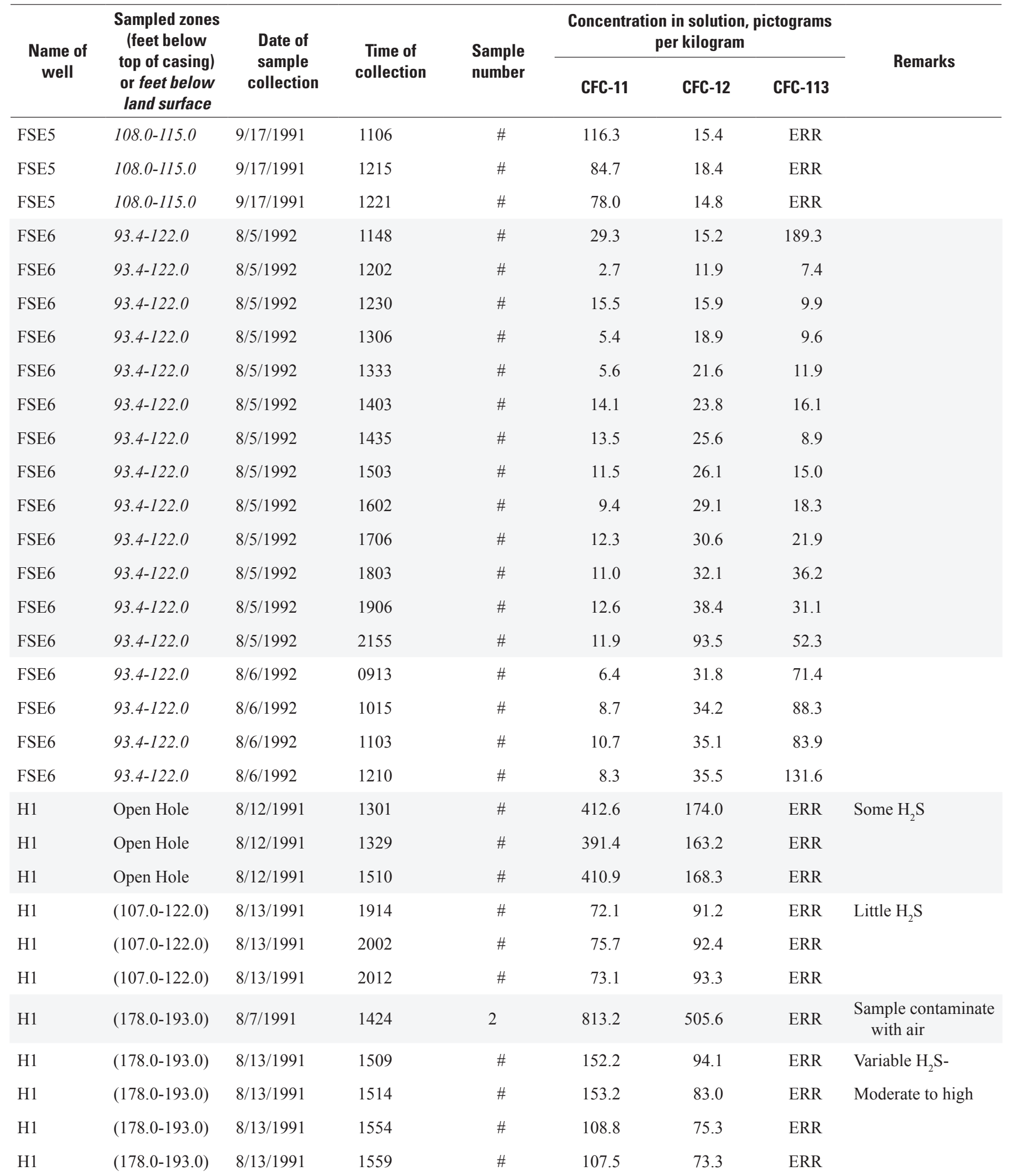


Table 39. Concentrations of gases dissolved in water collected from selected wells in the Mirror Lake watershed, New Hampshire: chlorofluorocarbons.-Continued

[Date of sample collection is by month/day/year; $\mathrm{CFC}$, chlorofluorocarbon; $\mathrm{H}_{2} \mathrm{~S}$, hydrogen sulfide; Cu, copper; S.C., specific conductance; “, inch]

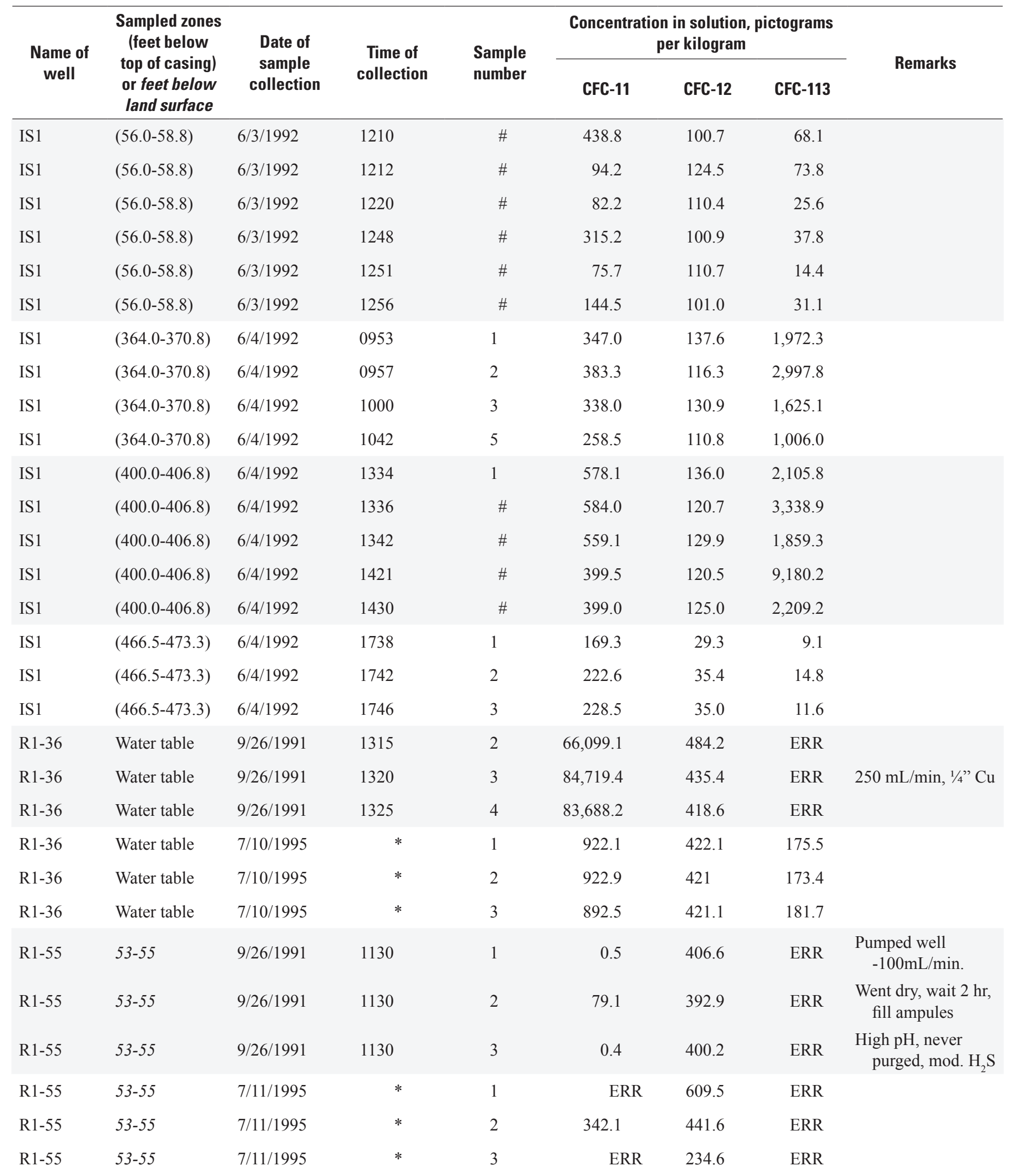


Table 39. Concentrations of gases dissolved in water collected from selected wells in the Mirror Lake watershed, New Hampshire: chlorofluorocarbons.-Continued

[Date of sample collection is by month/day/year; CFC, chlorofluorocarbon; $\mathrm{H}_{2} \mathrm{~S}$, hydrogen sulfide; Cu, copper; S.C., specific conductance; “, inch]

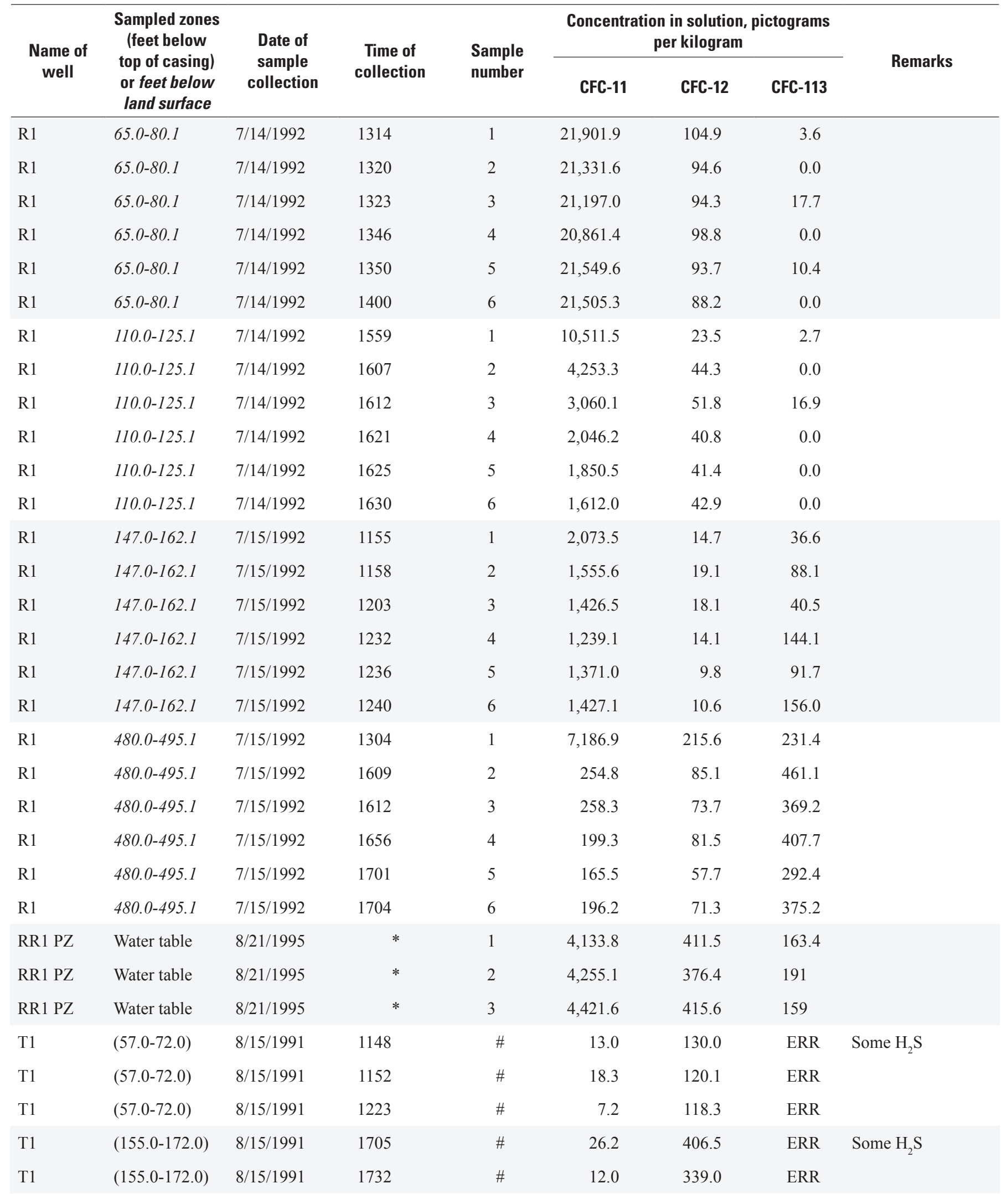


Table 39. Concentrations of gases dissolved in water collected from selected wells in the Mirror Lake watershed, New Hampshire: chlorofluorocarbons.-Continued

[Date of sample collection is by month/day/year; $\mathrm{CFC}$, chlorofluorocarbon; $\mathrm{H}_{2} \mathrm{~S}$, hydrogen sulfide; $\mathrm{Cu}$, copper; S.C., specific conductance; “, inch]

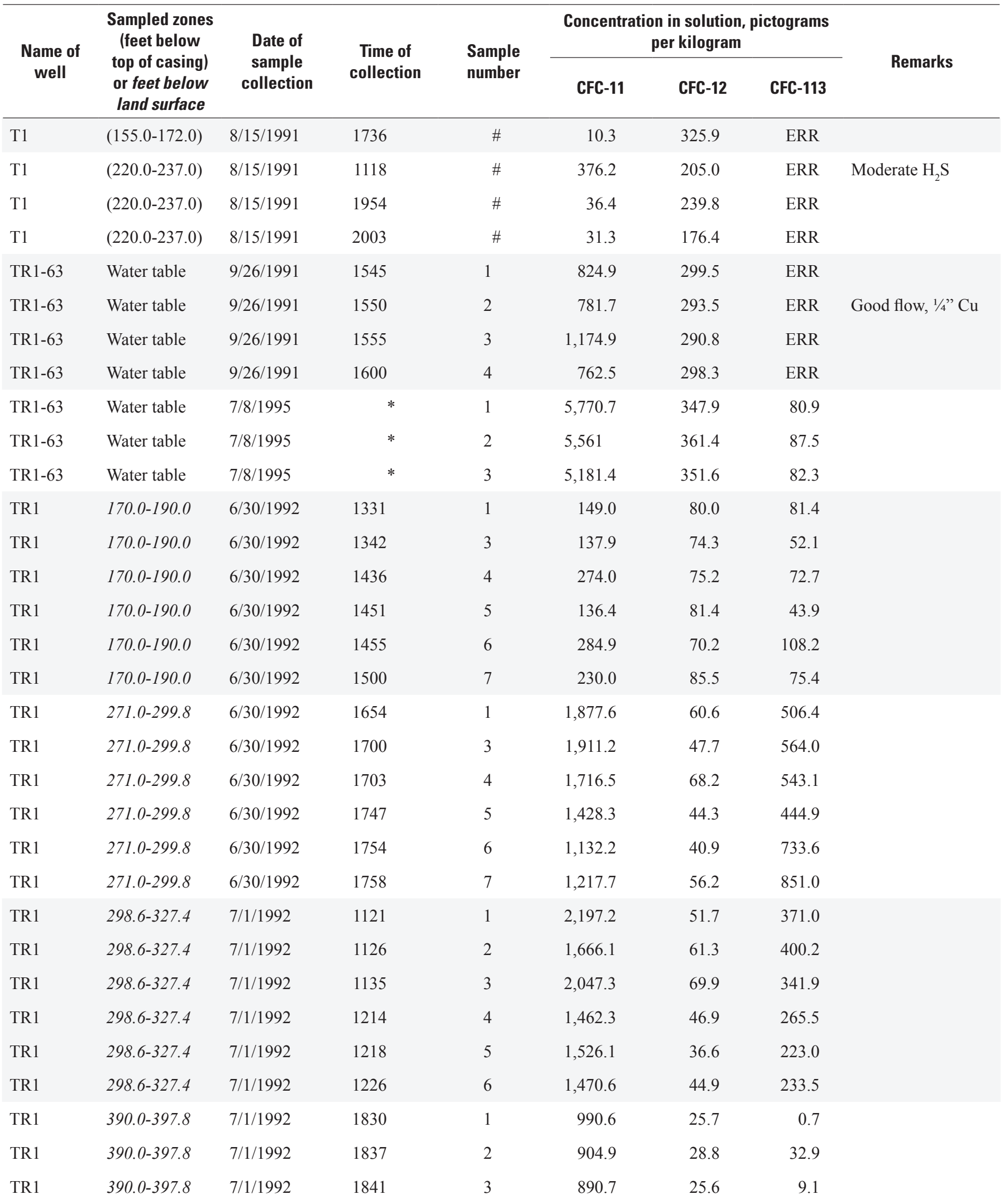


Table 39. Concentrations of gases dissolved in water collected from selected wells in the Mirror Lake watershed, New Hampshire: chlorofluorocarbons.-Continued

[Date of sample collection is by month/day/year; CFC, chlorofluorocarbon; $\mathrm{H}_{2} \mathrm{~S}$, hydrogen sulfide; Cu, copper; S.C., specific conductance; “, inch]

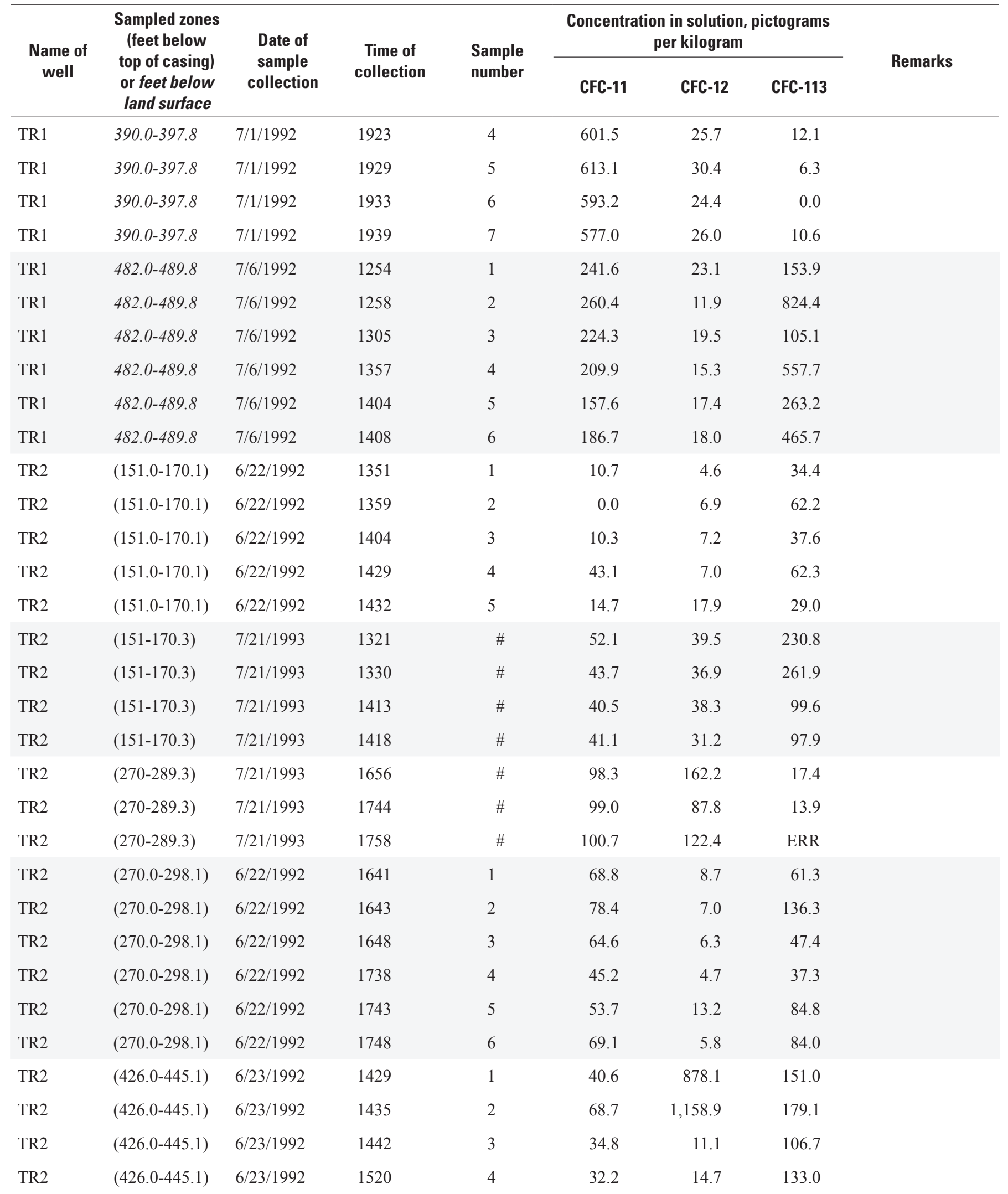


Table 39. Concentrations of gases dissolved in water collected from selected wells in the Mirror Lake watershed, New Hampshire: chlorofluorocarbons.-Continued

[Date of sample collection is by month/day/year; $\mathrm{CFC}$, chlorofluorocarbon; $\mathrm{H}_{2} \mathrm{~S}$, hydrogen sulfide; $\mathrm{Cu}$, copper; S.C., specific conductance; “, inch]

\begin{tabular}{|c|c|c|c|c|c|c|c|c|}
\hline \multirow{2}{*}{$\begin{array}{l}\text { Name of } \\
\text { well }\end{array}$} & \multirow{2}{*}{$\begin{array}{l}\text { Sampled zones } \\
\text { (feet below } \\
\text { top of casing) } \\
\text { or feet below } \\
\text { land surface }\end{array}$} & \multirow{2}{*}{$\begin{array}{c}\text { Date of } \\
\text { sample } \\
\text { collection }\end{array}$} & \multirow{2}{*}{$\begin{array}{l}\text { Time of } \\
\text { collection }\end{array}$} & \multirow{2}{*}{$\begin{array}{l}\text { Sample } \\
\text { number }\end{array}$} & \multicolumn{3}{|c|}{$\begin{array}{c}\text { Concentration in solution, pictograms } \\
\text { per kilogram }\end{array}$} & \multirow{2}{*}{ Remarks } \\
\hline & & & & & CFC-11 & CFC-12 & CFC-113 & \\
\hline TR2 & $(426.0-445.1)$ & $6 / 23 / 1992$ & 1529 & 5 & 32.8 & 11.2 & 78.6 & \\
\hline TR2 & $(426.0-445.1)$ & $6 / 23 / 1992$ & 1539 & 6 & 55.2 & 8.9 & 123.2 & \\
\hline TR2 & $(426-445.3)$ & $7 / 22 / 1993$ & 1014 & $\#$ & 35.7 & 20.7 & 34.6 & \\
\hline TR2 & $(426-445.3)$ & $7 / 22 / 1993$ & 1025 & \# & 28.1 & 10.8 & 19.8 & \\
\hline
\end{tabular}

$1 *$, indicates this characteristic was not available for the well on the given date.

2 \#, indicates sample number for was not reported for sample collected at the time noted.

${ }^{3}$ ERR indicates interferences, cannot be quantified.

Table 40. Chemical characteristics of groundwater from bedrock well FSE4 in the Mirror Lake watershed, New Hampshire.

[Analyses were done by the Institute of Ecosystem Studies (D.C. Buso and Scott Nolan). Date of sample collection is by month/day/year]

\begin{tabular}{|c|c|c|c|c|c|c|}
\hline \multirow{2}{*}{$\begin{array}{c}\text { Name of } \\
\text { well }\end{array}$} & \multirow{2}{*}{$\begin{array}{c}\text { Depth below } \\
\text { surface, in } \\
\text { feet }\end{array}$} & \multirow{2}{*}{$\begin{array}{l}\text { Date of } \\
\text { sample } \\
\text { collection }\end{array}$} & \multicolumn{2}{|c|}{$\begin{array}{c}\text { Concentration in milligrams } \\
\text { per liter }\end{array}$} & \multirow{2}{*}{$\begin{array}{c}\text { Concen- } \\
\text { tration in } \\
\text { micromoles } \\
\text { per liter } \\
\text { Dissolved } \\
\text { inorganic } \\
\text { carbon }\end{array}$} & \multirow{2}{*}{$\begin{array}{c}\text { Relative } \\
\text { height of gas } \\
\text { chromato- } \\
\text { graph peak } \\
\text { indicating } \\
\text { presence of } \\
\text { Methane }\end{array}$} \\
\hline & & & $\begin{array}{l}\text { Dissolved } \\
\text { oxygen }\end{array}$ & $\begin{array}{l}\text { Dissolved } \\
\text { organic } \\
\text { carbon }\end{array}$ & & \\
\hline FSE4 & $65-85$ & $10 / 23 / 86$ & 2.95 & 8.4 & 2.8 & Low \\
\hline FSE4 & $80-100$ & $10 / 26 / 86$ & 0.00 & 3.6 & 5.4 & Very low \\
\hline FSE4 & $135-155$ & $10 / 23 / 86$ & 0.00 & 1.9 & 4.0 & Medium low \\
\hline FSE4 & $430-450$ & $10 / 29 / 86$ & 0.00 & 0.6 & 13.1 & Very low \\
\hline
\end{tabular}


Table 41. Chemical characteristics of water collected from selected wells in the Mirror Lake watershed, New Hampshire: hardness:

[Date of sample collection is by month/day/year. $\mathrm{CaCO}_{3}$, calcium carbonate; $\mathrm{A}, \mathrm{B}, \mathrm{C}$, sample zones]

\begin{tabular}{|c|c|c|c|c|}
\hline \multirow[b]{2}{*}{ Name of well } & \multirow{2}{*}{$\begin{array}{c}\text { Sampled zones } \\
\text { (feet below top } \\
\text { of casing) or } \\
\text { feet below land } \\
\text { surface }\end{array}$} & \multirow[b]{2}{*}{$\begin{array}{l}\text { Date of sample } \\
\text { collection }\end{array}$} & \multicolumn{2}{|c|}{ Milligrams per liter } \\
\hline & & & $\begin{array}{l}\text { Hardness total as } \\
\qquad \mathrm{CaCO}_{3}\end{array}$ & $\begin{array}{c}\text { Hardness } \\
\text { noncarbonate } \\
\text { whole water total } \\
\text { field as } \mathrm{CaCO}_{3}\end{array}$ \\
\hline W3 & Water table & $5 / 30 / 1990$ & 15 & 0 \\
\hline W26 & Water table & $5 / 23 / 1990$ & 23 & 0 \\
\hline S-40 & Water table & $5 / 22 / 1990$ & 11 & 3 \\
\hline CO WT & Water table & $5 / 9 / 1990$ & 7 & 0 \\
\hline CO1 & B (101-209) & $5 / 10 / 1990$ & 150 & 41 \\
\hline $\mathrm{CO} 1$ & B (104-116) & $6 / 21 / 1990$ & 150 & 58 \\
\hline $\mathrm{CO} 1$ & C (409-421) & $6 / 22 / 1990$ & 110 & 4 \\
\hline $\mathrm{CO} 2$ & A $(25-104)$ & $5 / 9 / 1990$ & 54 & 0 \\
\hline $\mathrm{CO} 2$ & B (163-171) & $6 / 29 / 1990$ & 130 & $* 1$ \\
\hline FS1-17 & Water table & $5 / 30 / 1990$ & 20 & 0 \\
\hline FS1-35 & $33-35$ & $5 / 30 / 1990$ & 29 & 0 \\
\hline FS1 & $\mathrm{A}(55-105)$ & $5 / 31 / 1990$ & 22 & 0 \\
\hline FS1 & $\mathrm{C}(217-450)$ & $5 / 25 / 1990$ & 71 & 0 \\
\hline FS2 & A (32-105) & $5 / 22 / 1990$ & 21 & 0 \\
\hline FS2 & B (133-169) & 8/7/1990 & $*$ & $*$ \\
\hline FS2 & $\mathrm{C}(236-251)$ & $8 / 6 / 1990$ & 220 & $*$ \\
\hline FS3-22 & $20-22$ & $5 / 24 / 1990$ & 17 & 0 \\
\hline FS3 & A $(38-84)$ & $5 / 23 / 1990$ & 44 & 0 \\
\hline FS3 & A $(60-75)$ & $8 / 10 / 1990$ & 43 & $*$ \\
\hline FS3 & C (197-645) & $5 / 25 / 1990$ & 92 & 0 \\
\hline FS3 & $\mathrm{C}(365-380)$ & 8/9/1990 & 77 & 0 \\
\hline FS3 & $C(530-545)$ & 8/9/1990 & 52 & $*$ \\
\hline FSE-23 & $21-23$ & $6 / 1 / 1990$ & 150 & $*$ \\
\hline FSE-43 & $41-43$ & $6 / 1 / 1990$ & 250 & $*$ \\
\hline FSE2 & A $(55-105)$ & $6 / 1 / 1990$ & 99 & $*$ \\
\hline FSE2 & B (107-215) & $6 / 1 / 1990$ & $*$ & $*$ \\
\hline K2-21 & Water table & $5 / 17 / 1990$ & 54 & 21 \\
\hline K2-41 & $39-41$ & $5 / 17 / 1990$ & 46 & 0 \\
\hline $\mathrm{K} 2$ & $(55-160)$ & $5 / 17 / 1990$ & 70 & 0 \\
\hline $\mathrm{K} 3-22$ & Water table & $5 / 16 / 1990$ & 12 & 7 \\
\hline K3-61 & $59-61$ & $5 / 16 / 1990$ & 24 & 0 \\
\hline
\end{tabular}


Table 41. Chemical characteristics of water collected from selected wells in the Mirror Lake watershed, New Hampshire: hardness.—Continued

[Date of sample collection is by month/day/year. $\mathrm{CaCO}_{3}$, calcium carbonate; $\mathrm{A}, \mathrm{B}, \mathrm{C}$, sample zones]

\begin{tabular}{llccc}
\hline & $\begin{array}{c}\text { Sampled zones } \\
\text { (feet below top } \\
\text { Name of well }\end{array}$ & Date of sample & \multicolumn{2}{c}{ Milligrams per liter } \\
\cline { 4 - 5 } & $\begin{array}{c}\text { ofeet below land } \\
\text { surface }\end{array}$ & collection & $\begin{array}{c}\text { Hardness total as } \\
\text { CaCO }_{3}\end{array}$ & $\begin{array}{c}\text { Hardness } \\
\text { noncarbonate } \\
\text { whole water total } \\
\text { field as CaCO }\end{array}$ \\
\hline K3 & $(75-175)$ & $5 / 16 / 1990$ & 84 & 0 \\
K1-8 & Water table & $5 / 21 / 1990$ & 9 & 4 \\
K1-39 & $37-39$ & $5 / 22 / 1990$ & 170 & 0 \\
K1 & borehole & $5 / 17 / 1990$ & $*$ & $*$ \\
TR1-63 & Water table & $5 / 15 / 1990$ & 18 & 3 \\
TR1 & A (177-199) & $5 / 15 / 1990$ & 50 & 0 \\
TR1 & B (200-299) & $5 / 17 / 1990$ & 76 & 0 \\
\hline
\end{tabular}

$1 *$, indicates analysis for this characteristic was not done for water collected from this well on the given date. 


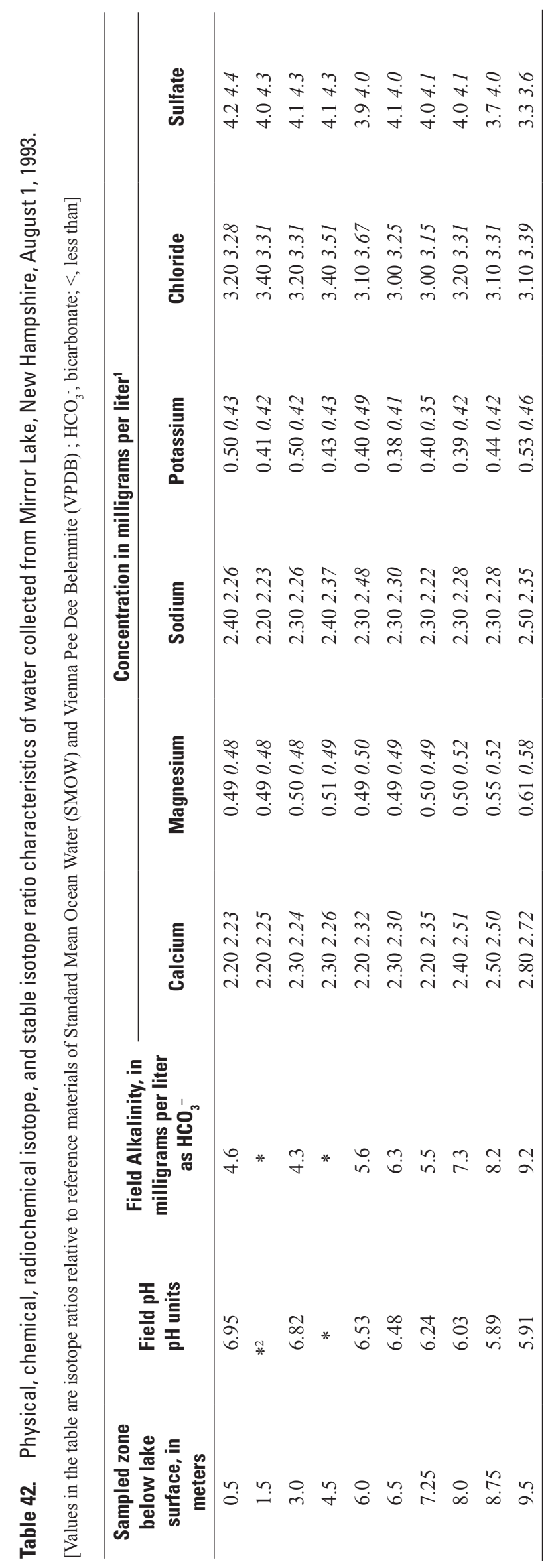




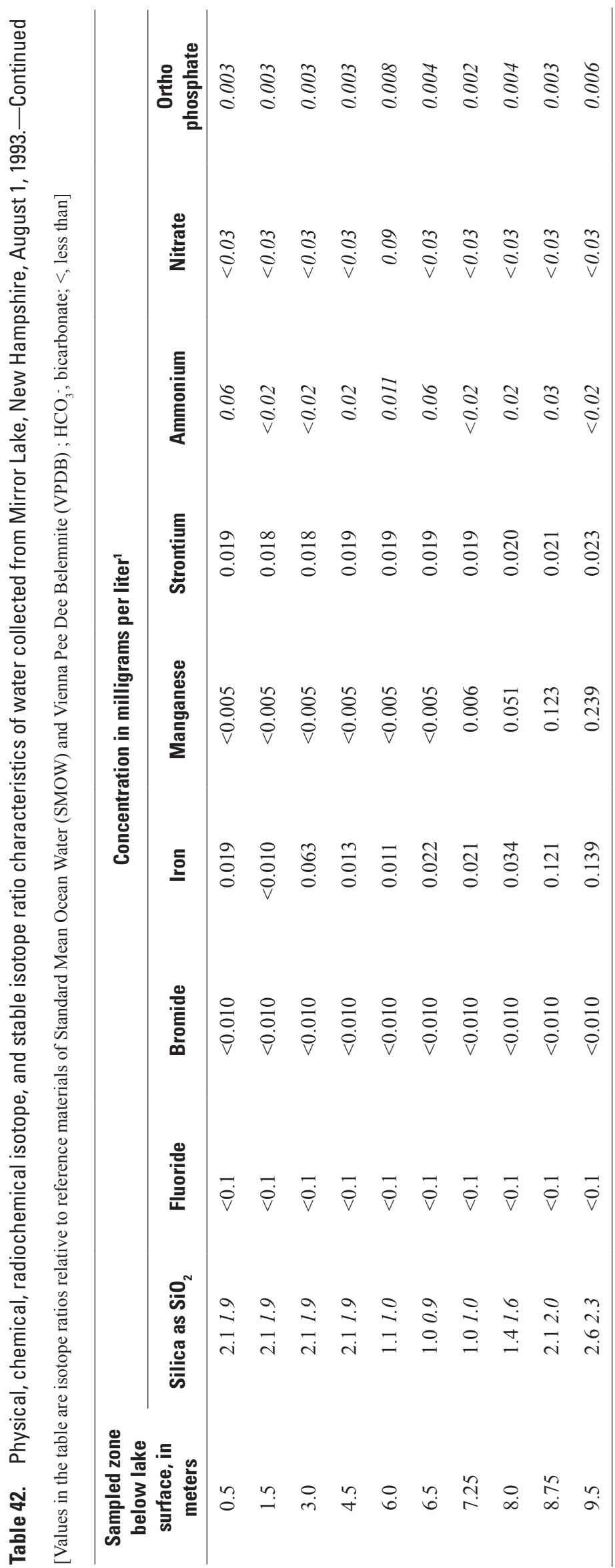




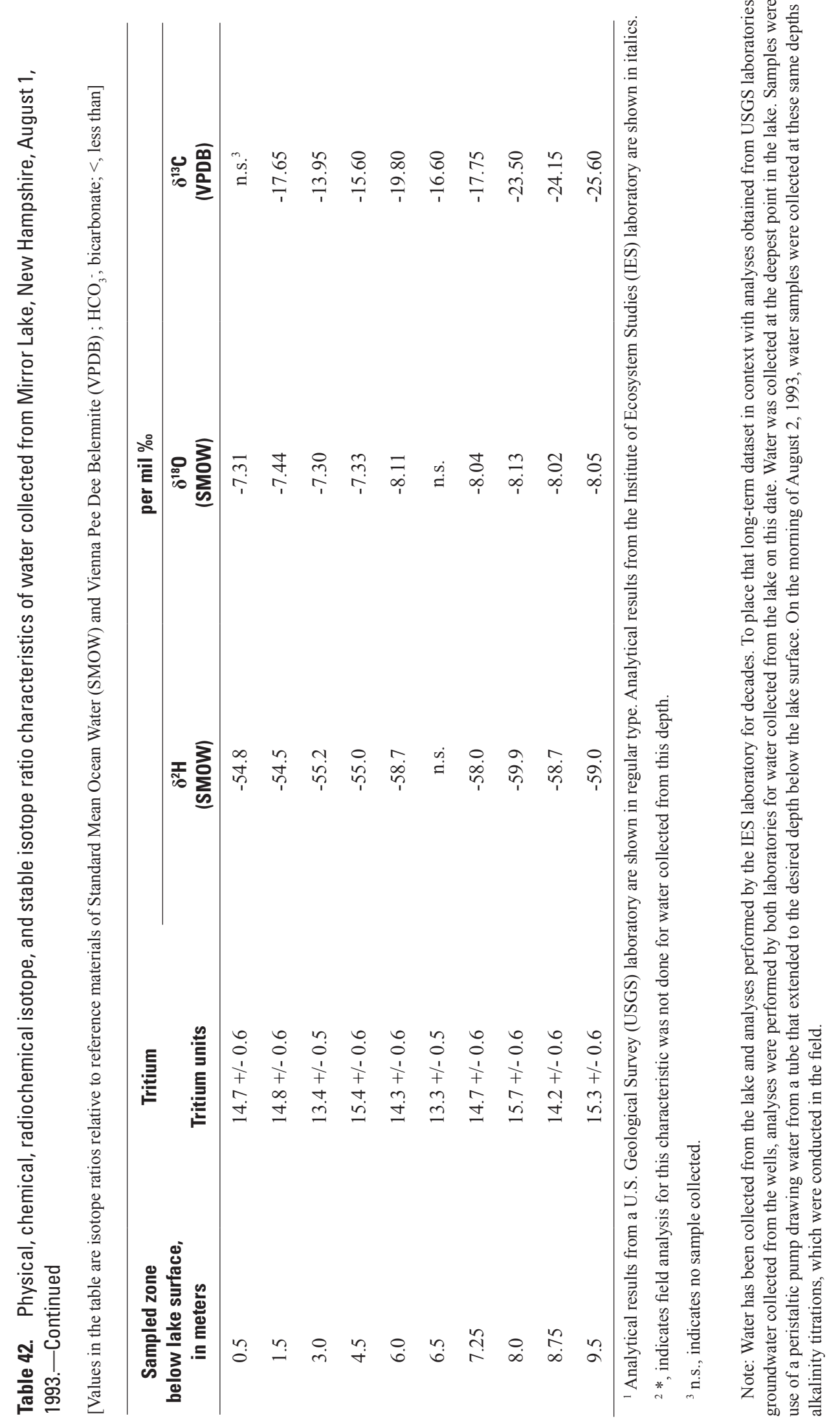




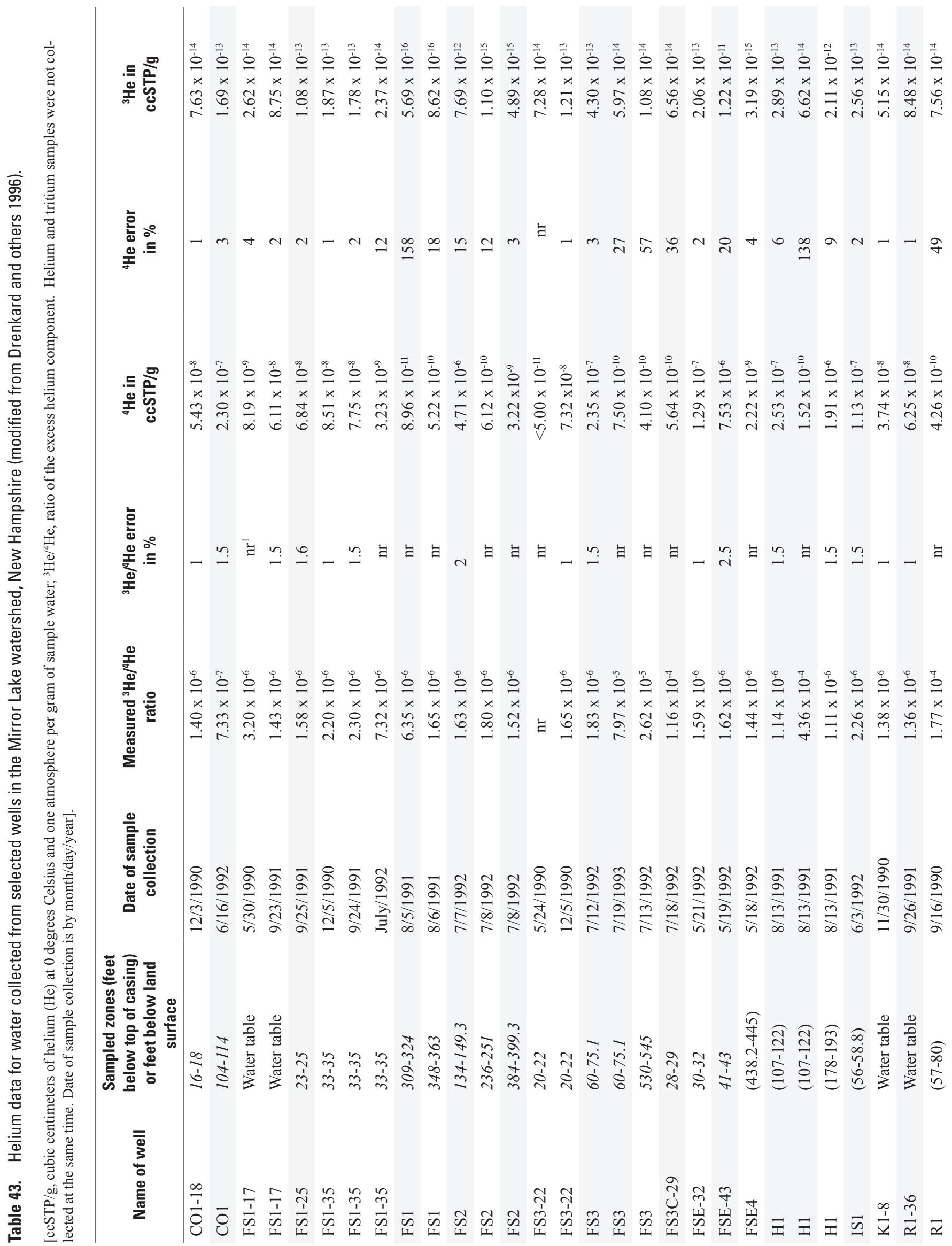




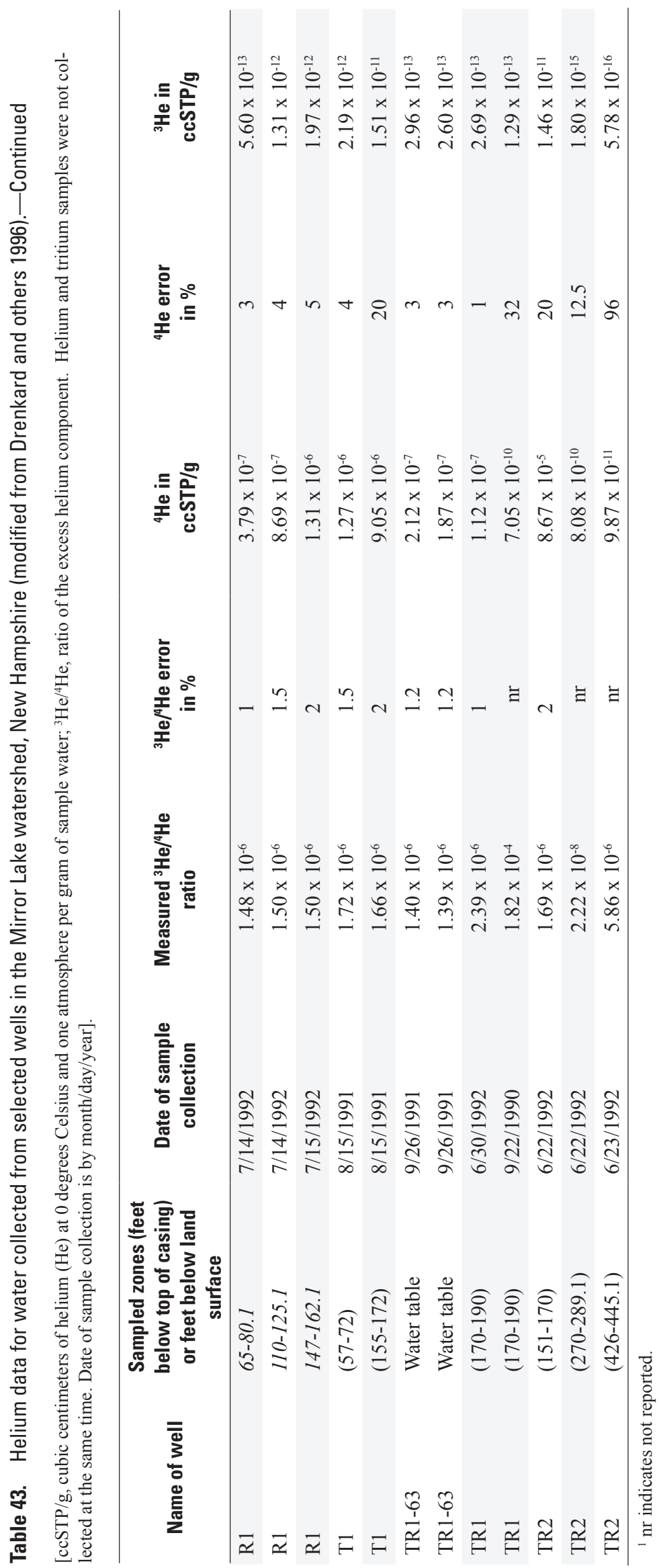


ISSN 2331-1258 